\title{
Archaeological Survey of Laughlin Air Force Base, Val Verde County, Texas
}

\author{
Cynthia L. Tennis \\ Center for Archaeological Research \\ Marcie Renner \\ Center for Archaeological Research \\ Robert J. Hard \\ Department of Anthropology, University of Texas at San Antonio
}

Follow this and additional works at: https://scholarworks.sfasu.edu/ita

Part of the American Material Culture Commons, Archaeological Anthropology Commons, Environmental Studies Commons, Other American Studies Commons, Other Arts and Humanities Commons, Other History of Art, Architecture, and Archaeology Commons, and the United States History Commons

Tell us how this article helped you.

This Article is brought to you for free and open access by the Center for Regional Heritage Research at SFA ScholarWorks. It has been accepted for inclusion in Index of Texas Archaeology: Open Access Gray Literature from the Lone Star State by an authorized editor of SFA ScholarWorks. For more information, please contact cdsscholarworks@sfasu.edu. 


\section{Archaeological Survey of Laughlin Air Force Base, Val Verde County, Texas}

Creative Commons License

(c) (i) (8)

This work is licensed under a Creative Commons Attribution-NonCommercial 4.0 International License 
Archaeological Survey of

Laughlin Air Farce Base.

Val Verde County. Texas

Cynthia L. Tennis, Marcie Runner. and Robert 9. Fard, editors

Anne A. Fax. Kevin 9. Gross, James O. Jones. Barbara A. Meissnor, Shirley 8. Mock. Lee C. Mort. Gary R. Raymond, and Anna Jean Taylor, contributors

Center for Archaeological Research The University of Texas at San Antonia Archaeological Survey Report. No. 239 1996 



\title{
Archaeological Survey of Laughlin Air Force Base, Val Verde County, Texas
}

Cynthia L. Tennis, Marcie Renner, and Robert J. Hard, editors

\author{
Anne A. Fox, Kevin J. Gross, James O. Jones, \\ Barbara A. Meissner, Shirley B. Mock, Lee C. Nordt, \\ Gerry R. Raymond, and Anna Jean Taylor, contributors
}

Robert J. Hard, principal investigator

Center for Archaeological Research The University of Texas at San Antonio Archaeological Survey Report, No. 239 
The following information is provided in accordance with the General Rules of Practice and Procedure, Chapter 41.11 (Investigative Reports), Texas Antiquities Committee:

1. Type of investigation: Survey

2. Project name: Laughlin Air Force Base Survey

3. County: Val Verde

4. Principal investigators: Robert J. Hard

5. Name and location of sponsoring agency: National Park Service, Rocky Mountain Region, Denver Colorado 80225-0287

6. Texas Antiquities Committee Permit No.: n/a

7. Published by the Center for Archaeological Research, The University of Texas at San Antonio, San Antonio, Texas 78249-0658, 1996

A list of publications offered by the Center for Archaeological Research is available. Call (210) 458-4378; write to the Center for Archaeological Research, The University of Texas at San Antonio, 6900 N. Loop 1604 W., http://www.csbs.utsa.edu/research/car/index.htm. 


\begin{abstract}
During the spring of 1994, the Center for Archaeological Research of The University of Texas at San Antonio conducted a 100-percent pedestrian survey of Laughlin Air Force Base and the Air Force Recreation Area and Marina in Val Verde County, Texas. In addition to the survey, limited paleontological and geomorphological evaluations were made.

One historic site, eight prehistoric sites, and one large site with both prehistoric and historic

viously recorded sites (De Vore 1993) were revisited. Diagnostic projectile points representing Late Paleoindian through Late Prehistoric occupations were recovered from five of the prehistoric sites. Late-nineteenth- and early twentieth-century artifacts were recovered from the Historic-period sites.

Eleven of the 13 total sites are recommended as eligible for nomination to the National Register of Historic Places.
\end{abstract} components were recorded. Additionally, three pre- 


\section{CONTENTS}

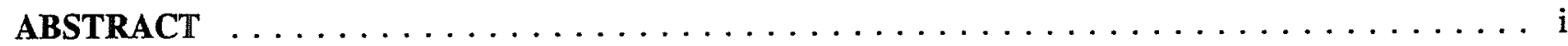

FIGURES $\ldots \ldots \ldots \ldots \ldots \ldots \ldots \ldots \ldots \ldots \ldots \ldots \ldots \ldots \ldots \ldots \ldots \ldots$

TABLES $\ldots \ldots \ldots \ldots \ldots \ldots \ldots \ldots \ldots \ldots \ldots \ldots \ldots \ldots \ldots \ldots \ldots$ vii

ACKNOWLEDGMENTS $\ldots \ldots \ldots \ldots \ldots \ldots \ldots \ldots \ldots \ldots \ldots \ldots \ldots \ldots \ldots \ldots$

Chapter 1. Introduction

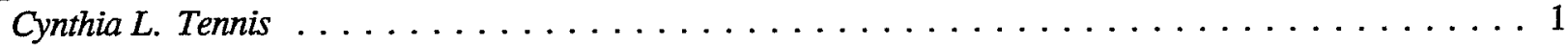

Chapter 2. Project Area

LOCATION AND ENVIRONMENT

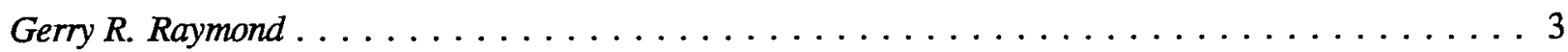

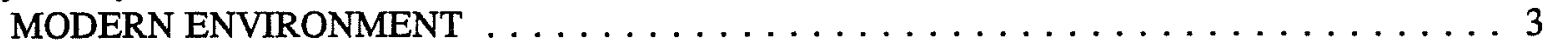

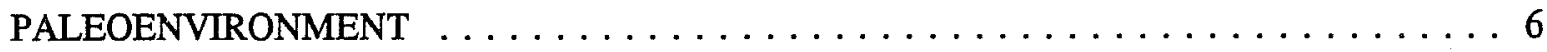

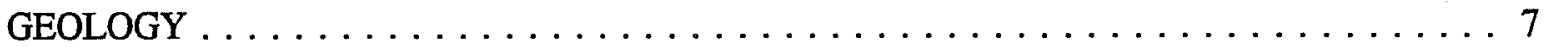

GEOMORPHOLOGICAL INVESTIGATIONS

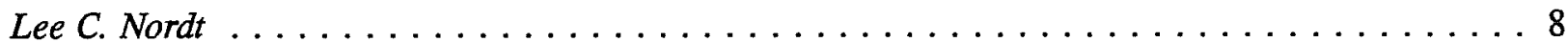

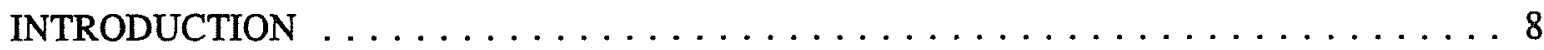

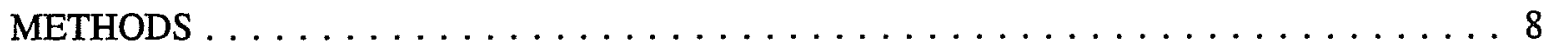

GEOMORPHIC OVERVIEW $\ldots \ldots \ldots \ldots \ldots \ldots \ldots \ldots \ldots \ldots \ldots$

UPLAND STRATIGRAPHY $\ldots \ldots \ldots \ldots \ldots \ldots \ldots \ldots \ldots \ldots \ldots \ldots$

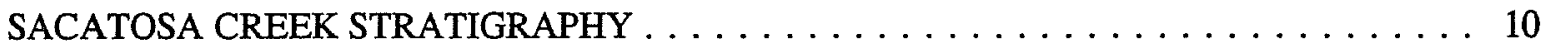

ZORRO CREEK STRATIGRAPHY $\ldots \ldots \ldots \ldots \ldots \ldots \ldots \ldots \ldots \ldots$

GEOARCHAEOLOGICAL INTERPRETATIONS $\ldots \ldots \ldots \ldots \ldots \ldots \ldots \ldots$

PALEONTOLOGY AND STRATIGRAPHY

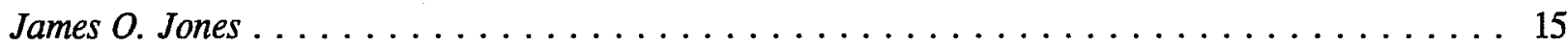

NORTHWEST SITE-DEL RIO FORMATION $\ldots \ldots \ldots \ldots \ldots \ldots \ldots \ldots \ldots \ldots$

SOUTHEAST SITE-BUDA FORMATION $\ldots \ldots \ldots \ldots \ldots \ldots \ldots \ldots \ldots \ldots$

MARINA SITE-SALMON PEAK LIMESTONE $\ldots \ldots \ldots \ldots \ldots \ldots \ldots \ldots \ldots$

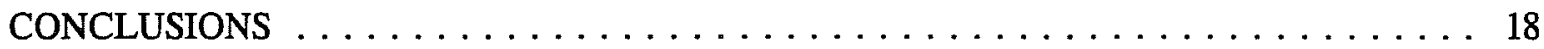

\section{Chapter 3. Methodology}

Robert J. Hard, Marcie Renner, and Anna Jean Taylor . . . . . . . . . . . . . . . . . . . 20

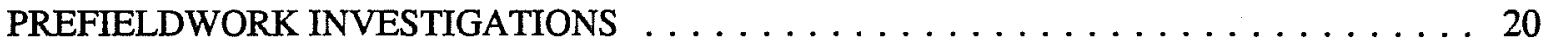

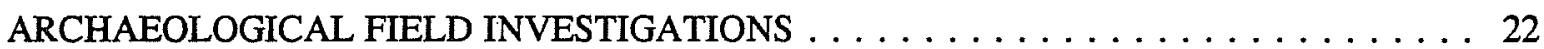

GEOMORPHOLOGICAL INVESTIGATIONS $\ldots \ldots \ldots \ldots \ldots \ldots \ldots \ldots \ldots \ldots \ldots$

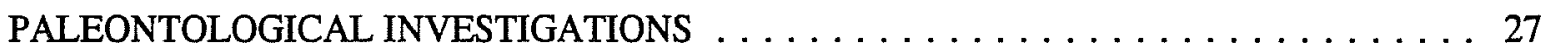

HISTORICAL FIELD INVESTIGATIONS $\ldots \ldots \ldots \ldots \ldots \ldots \ldots \ldots \ldots \ldots \ldots$

LABORATORY PROCEDURES $\ldots \ldots \ldots \ldots \ldots \ldots \ldots \ldots \ldots \ldots \ldots \ldots \ldots \ldots$

Chapter 4. Prehistoric Period Background

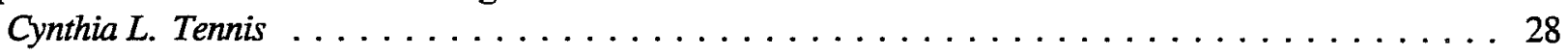

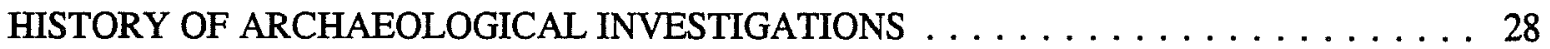

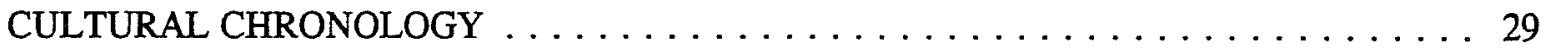

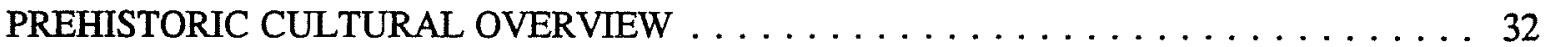

Chapter 5. Prehistoric Sites and Isolated Finds

Barbara A. Meissner, Anna Jean Taylor, Cynthia L. Tennis, and Kevin J. Gross . . . . . . . . 34

RESULTS 


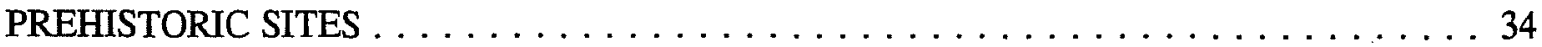

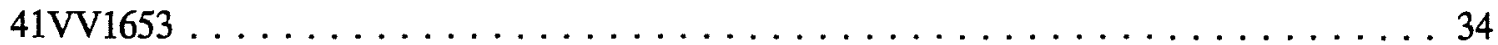

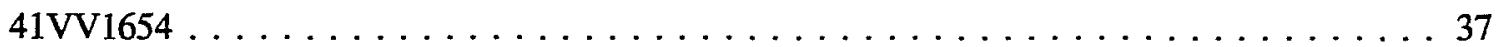

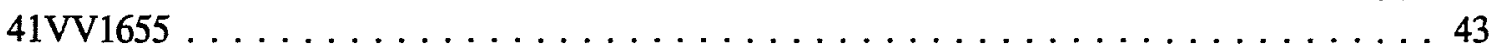

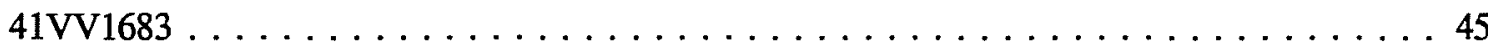

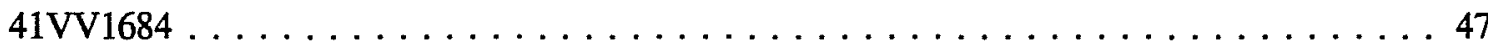

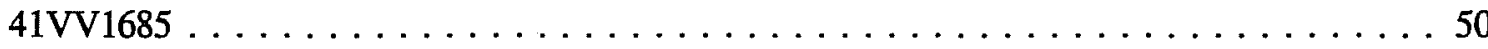

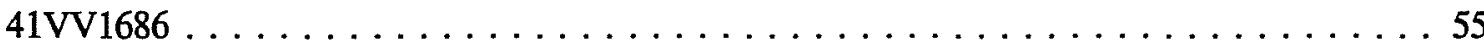

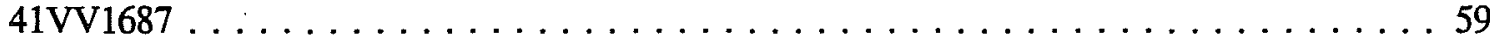

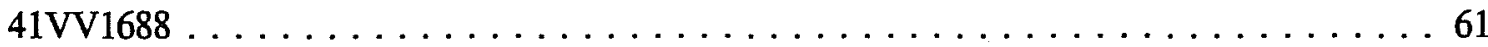

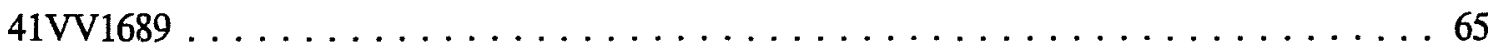

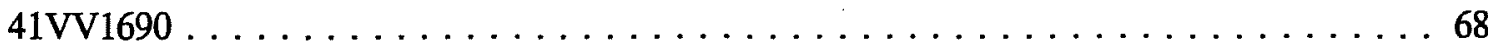

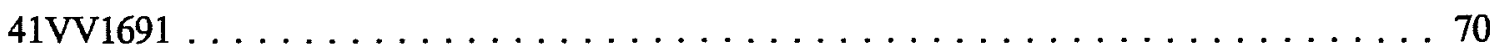

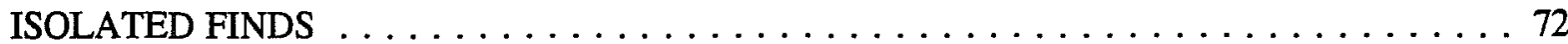

Chapter 6. Prehistoric Artifacts

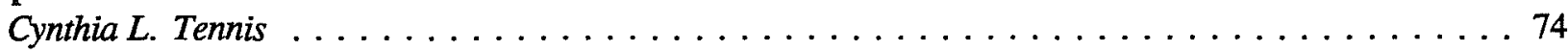

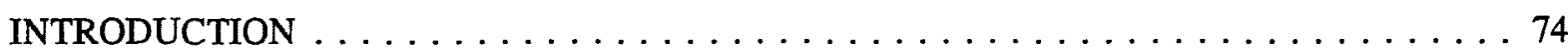

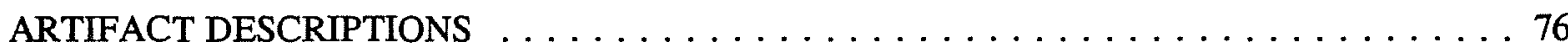

Chapter 7. Prehistoric Analysis

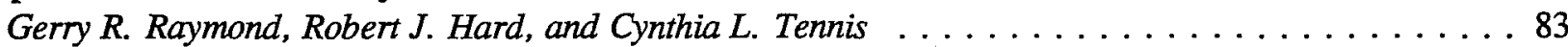

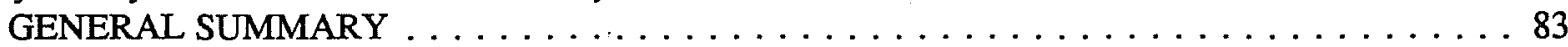

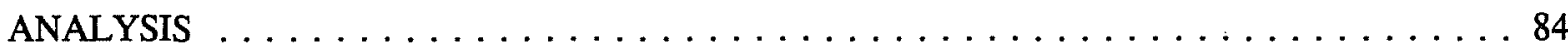

Chapter 8. Historic Period Background

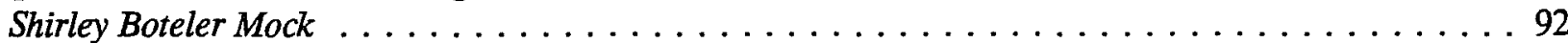

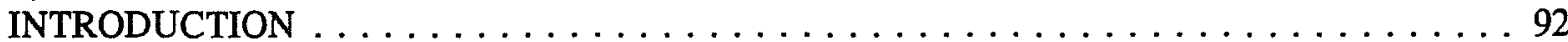

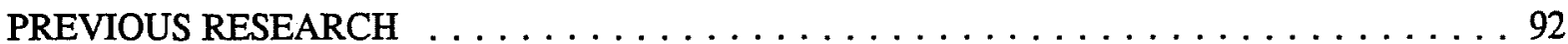

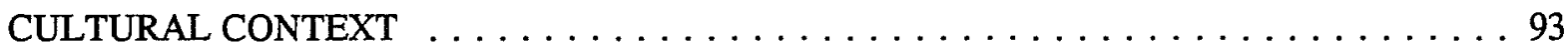

LAUGHLIN AIR FORCE BASE $\ldots \ldots \ldots \ldots \ldots \ldots \ldots \ldots$

Chapter 9. Historic Site Descriptions

Anne A. Fox, Anna Jean Taylor, and Barbara A. Meissner . . . . . . . . . . . . . . . 116

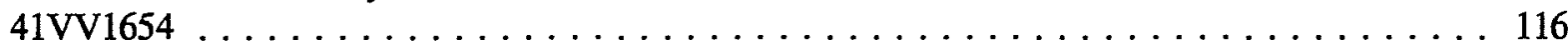

41VV1682, ZACATOSA RANCH HEADQUARTERS $\ldots \ldots \ldots \ldots \ldots \ldots \ldots \ldots \ldots \ldots$

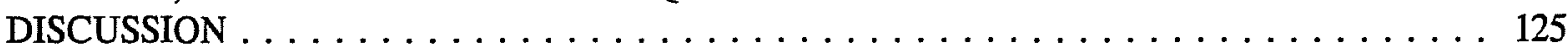

Chapter 10. Historic Artifact Analysis and Discussion

Anne A. Fox . . . . . . . . . . . . . . . . . . . . . . . . . . . . . . . . 126

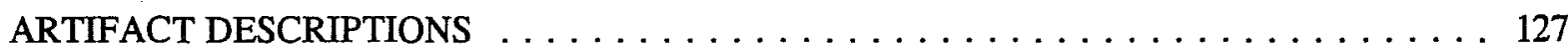

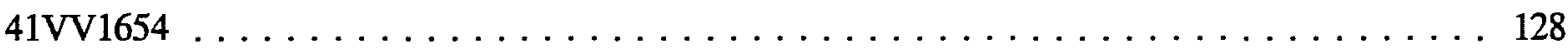

ZACATOSA RANCH HEADQUARTERS (41VV1682) $\ldots \ldots \ldots \ldots \ldots \ldots \ldots \ldots$

Chapter 11. Summary and Conclusions

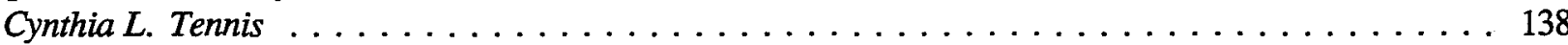

HISTORIC SITES . . . . . . . . . . . . . . . . . . . . . . . . . . 139

PREHISTORIC SITES . . . . . . . . . . . . . . . . . . . . . . . . . 139

SUGGESTIONS FOR FURTHER RESEARCH $\ldots \ldots \ldots \ldots \ldots \ldots \ldots \ldots \ldots$ 
Chapter 12. Site Assessments and Recommendations

Cynthia L. Tennis, Anna Jean Taylor, and Robert J. Hard . . . . . . . . . . . . . . . . . . 141

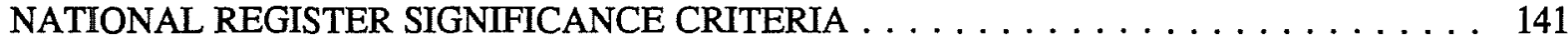

NATIONAL REGISTER RECOMMENDATIONS $\ldots \ldots \ldots \ldots \ldots \ldots \ldots \ldots \ldots \ldots \ldots$

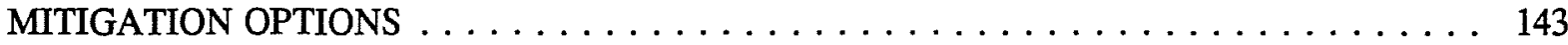

SITES NOT RECOMMENDED FOR FURTHER INVESTIGATION $\ldots \ldots \ldots \ldots \ldots \ldots$

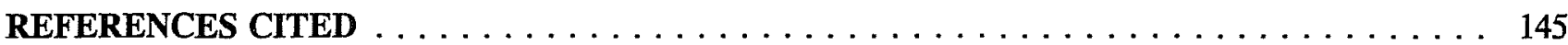

APPENDIX A: GEOMORPHOLOGICAL DATA

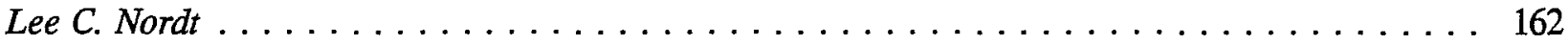

APPENDIX B: PALEONTOLOGICAL DATA

James $O$. Jones $\ldots \ldots \ldots \ldots \ldots \ldots \ldots \ldots \ldots \ldots \ldots \ldots$

APPENDIX C: FORMS $\ldots \ldots \ldots \ldots \ldots \ldots \ldots \ldots \ldots \ldots \ldots \ldots \ldots$

APPENDIX D: LAUGHLIN SURVEY ARTIFACT CATALOG $\ldots \ldots \ldots \ldots \ldots \ldots \ldots$ 


\section{FIGURES}

1-1. Laughlin AFB location map. . . . . . . . . . . . . . . . . . . . . 1

2-1. Map of the project area showing soil description localities and landforms $\ldots \ldots \ldots \ldots \ldots$

2-2. Trenches from two upland colluvial valley. . . . . . . . . . . . . . . . . . 10

2-3. Composite stratigraphic cross-section of Sacatosa Creek based on selected trenches and gully . . . 12

2-4. Composite stratigraphic cross-section of trenches from Zorro Creek . . . . . . . . . . . . . 13

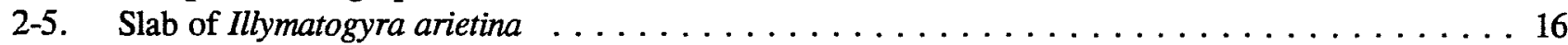

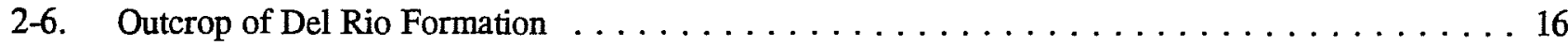

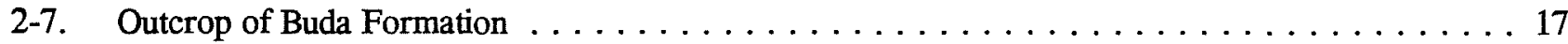

2-8. Outcrop of Salmon Peak Limestone at low water level . . . . . . . . . . . . . . . 18

2-9. Salmon Peak Limestone above the low water level . . . . . . . . . . . . . . . . . . . 19

3-1. Map of the Air Force Recreational Area and Marina . . . . . . . . . . . . . . . . 22

3-2. Map of Laughlin AFB with areas excluded from the survey indicated . . . . . . . . . . . 23

3-3. Map of Laughlin AFB showing sectors delineated for the survey $\ldots \ldots \ldots \ldots \ldots \ldots$

4-1. Regional chronology . . . . . . . . . . . . . . . . . . . . . . . . . 29

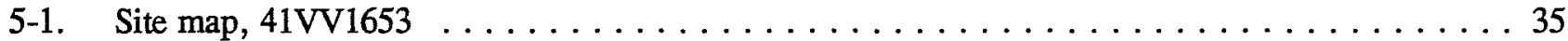

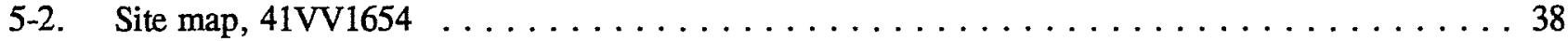

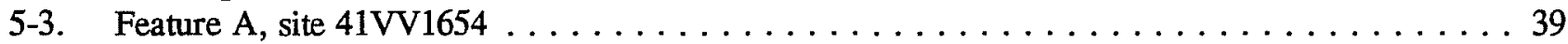

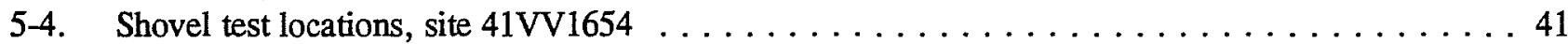

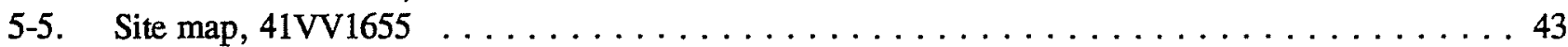

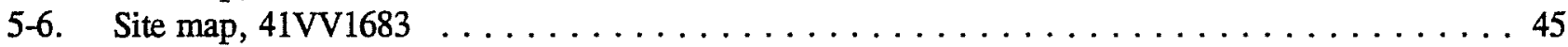

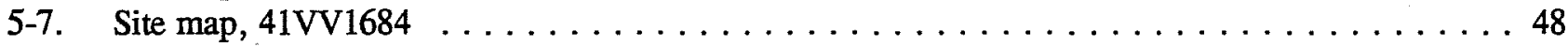

5-8. Site map, 41VV1685. A, B, C, and $\mathrm{D}$ denote site areas $\ldots \ldots \ldots \ldots \ldots \ldots \ldots \ldots \ldots$

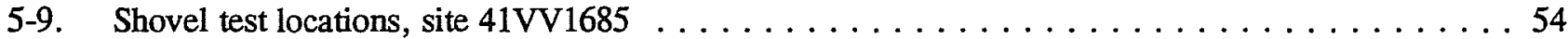

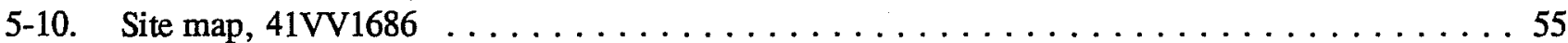

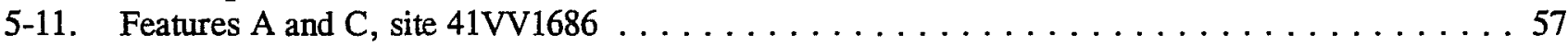

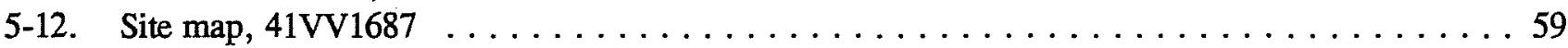

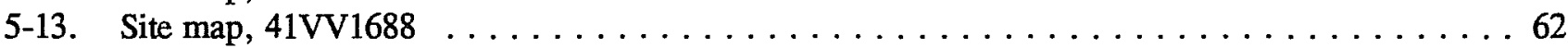

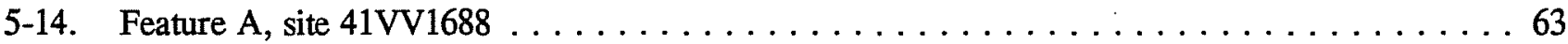

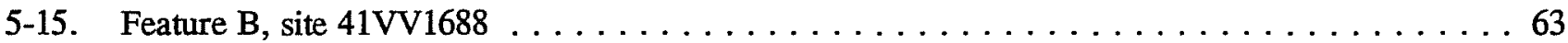

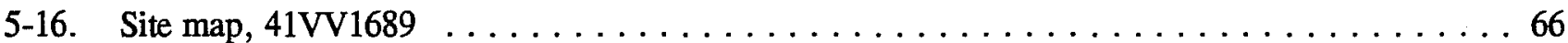

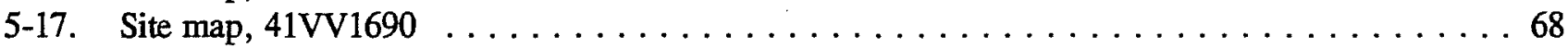

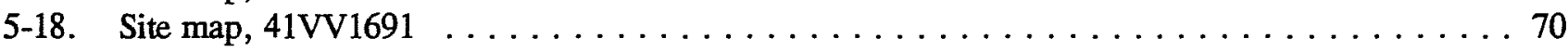

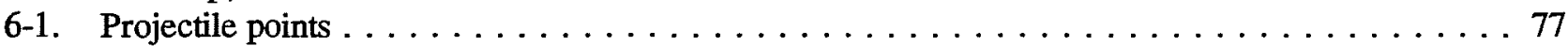

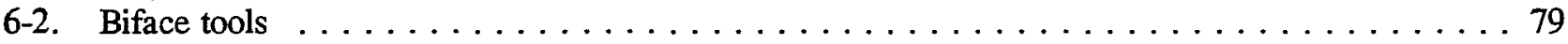

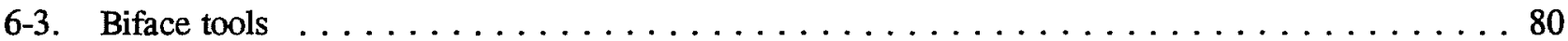

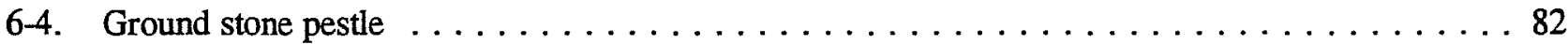

7-1. Reduction stage frequencies, floodplain vs. terrace sites $\ldots \ldots \ldots \ldots \ldots \ldots$

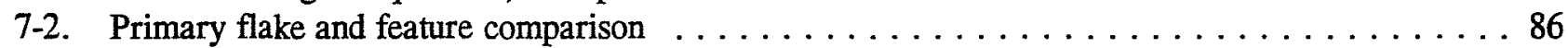

8-1. Map of the proposed Air Corps Training Center, $1940 \ldots \ldots \ldots \ldots \ldots$

8-2. Portrait of Doña Paula Losoya Taylor de Rivera. . . . . . . . . . . . . . . . . . . . . . 98

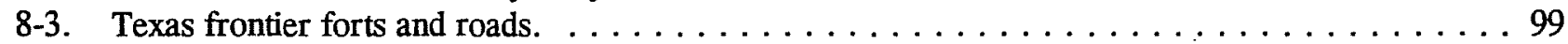

8-4. Advertisement of town lots in Del Rio, Texas, in $1890 \ldots \ldots \ldots \ldots$. . . . . . . . . . . . 100

8-5. Members of the Texas Sheep and Goat Raisers' Association . . . . . . . . . . . . . . . . . . . 106

8-6. Map of Laughlin Air Base showing original long-lot grants and ranches . . . . . . . . . . . . . 109

8-7. Florence Marshall Major with her younger brother, Gilbert G. Marshall, ca. 1942 . . . . . . . . 110

8-8. George M. Marshall and his wife Susie, in front of the ranch corral . . . . . . . . . . . . 111

8-9. George M. Marshall and his brother Taylor, standing on the porch of the little adobe house . . . 111

8-10. George M., Susie, and Taylor Marshall, and the cook at the chuck wagon . . . . . . . . . 112

8-11. Rambouillet sheep herd to the west of the ranch headquarters . . . . . . . . . . . . 112

8-12. Gilbert G. Marshall shown with his horse, near the stock tank . . . . . . . . . . . . . 113 
8-13. Gilbert G. Marshall showing off his blue-ribbon sheep at a 4-H event . . . . . . . . . . . 113

8-14. Macye Marshall with her infant daughter Florence, in front of the main house. . . . . . . . . . 114

8-15. Gilbert C. Marshall with his wife Macye, a Marshall cousin, and the cousin's daughter . . . . 114

8-16. Josepha, wife of Tomás, the Mexican-Indian foreman, with her children . . . . . . . . . . 115

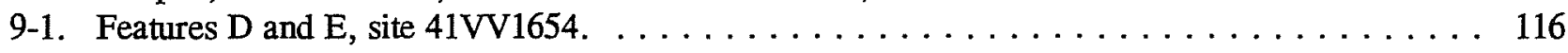

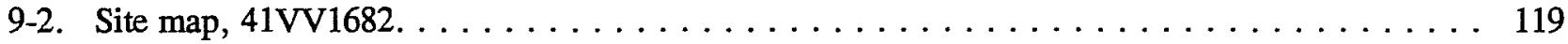

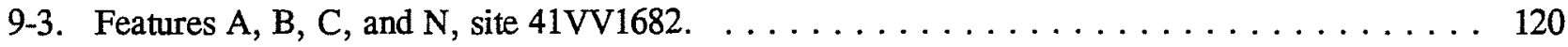

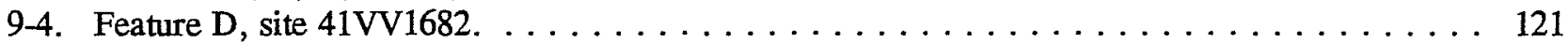

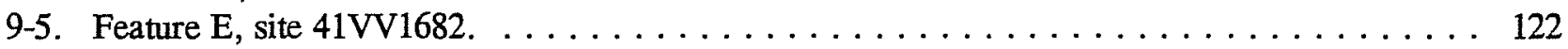

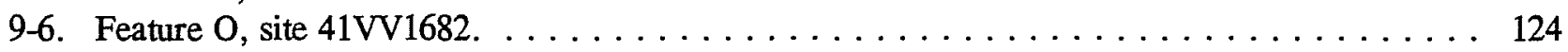

10-1. Adobe house, ca. 1942, looking southwest . . . . . . . . . . . . . . . . . . 130

10-2. Frame house, ca. 1942, looking west. Note addition on left . . . . . . . . . . . . 130

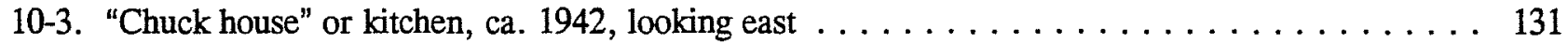

10-4. Labor or bunk house and garage (right), ca. 1942, looking west . . . . . . . . . . . . . 131

10-5. Garage, ca. 1942, looking east . . . . . . . . . . . . . . . . . . . . . 132

10-6. Feed house, ca. 1942, looking southwest . . . . . . . . . . . . . . . . . . . 132

10-7. Saddle house, ca. 1942 , looking southwest $\ldots \ldots \ldots \ldots \ldots \ldots \ldots \ldots \ldots \ldots$

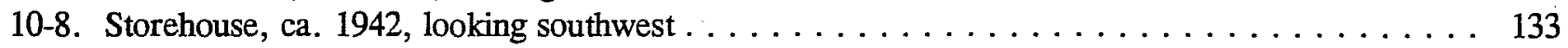

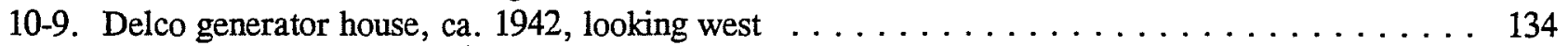

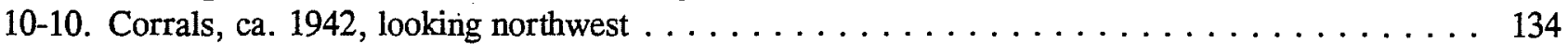

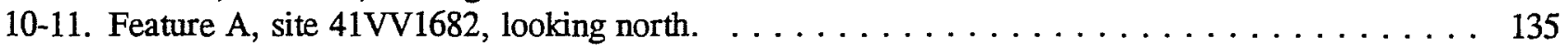

10-12. Watering troughs, west of ranch house, ca. $1942 \ldots \ldots \ldots \ldots \ldots \ldots \ldots$

10-13. 41VV1682, Feature D, concrete foundation, looking north. . . . . . . . . . . . 136

10-14. Zacatosa Ranch Headquarters, ca. 1942, looking northwest . . . . . . . . . . . . . . 137

10-15. Zacatosa Ranch Headquarters, 1994, looking northwest . . . . . . . . . . . . . . . . . . . 137 


\section{TABLES}

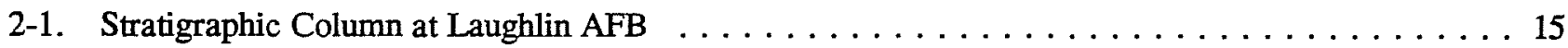

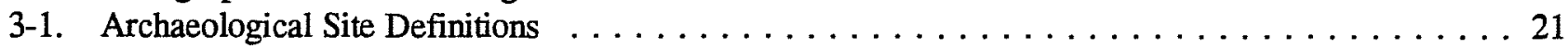

3-2. Laughlin Air Force Base Archaeological Survey Zones . . . . . . . . . . . . . . . . . 21

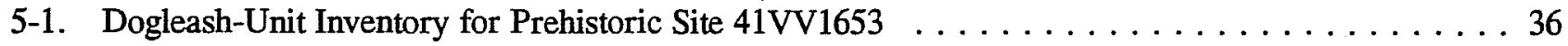

5-2. Dogleash-Unit Inventories for Site 41VV1654, Prehistoric Components . . . . . . . . . . . 40

5-3. Shovel Tests and Levels which Produced Artifacts on Site 41VV1654 . . . . . . . . . . . . . 42

5-4. Dogleash-Unit Inventory for Prehistoric Site 41VV1655 . . . . . . . . . . . . . . . . 44

5-5. Shovel Tests and Levels which Produced Artifacts on Site $41 \mathrm{VV1} 1655 \ldots \ldots \ldots$. . . . . . . . . . 44

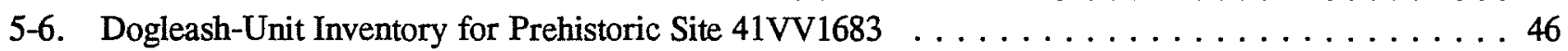

5-7. Shovel Tests and Levels which Produced Artifacts on Site 41 VV1683 . . . . . . . . . . . . 47

5-8. Dogleash-Unit Inventory for Prehistoric Site 41VV1684 . . . . . . . . . . . . . . . . . . . 49

5-9. Dogleash-Unit Inventory for Prehistoric Site 41VV1685, Area A . . . . . . . . . . . . . . . 52

5-10. Dogleash-Unit Inventory for Prehistoric Site 41VV1685, Area B . . . . . . . . . . . . . . 52

5-11. Dogleash-Unit Inventory for Prehistoric Site 41VV1685, Area C . . . . . . . . . . . . . 53

5-12. Dogleash-Unit Inventory for Prehistoric Site 41VV1685, Area D . . . . . . . . . . . . . . 53

5-13. Shovel Tests and Levels which Produced Artifacts on Site 41VV1685 . . . . . . . . . . . . 54

5-14. Dogleash-Unit Inventory for Site $41 V V 1686 \ldots \ldots \ldots \ldots \ldots \ldots \ldots \ldots$

5-15. Shovel Tests and Levels which Produced Artifacts on Site 41VV1686 . . . . . . . . . . . . 58

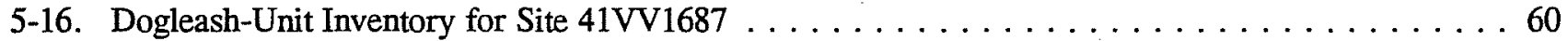

5-17. Shovel Tests and Levels which Produced Artifacts on Site 41VV1687 . . . . . . . . . . . 61

5-18. Dogleash-Unit Inventory for Site 41VV1688 . . . . . . . . . . . . . . . . . . . . 64

5-19. Shovel Tests and Levels which Produced Artifacts on Site 41VV1688 . . . . . . . . . . . . . 65

5-20. Dogleash-Unit Inventory for Prehistoric Site $41 V V 1689 \ldots \ldots \ldots \ldots$. . . . . . . . . . . 67

5-21. Shovel Tests and Levels which Produced Artifacts on Site 41VV1689 . . . . . . . . . . . . 67

5-22. Dogleash-Unit Inventory for Prehistoric Site 41VV1691 . . . . . . . . . . . . . . . 71

5-23. Shovel Tests and Levels which Produced Artifacts on Site 41VV1691 . . . . . . . . . . . . . 71

6-1. Dogleash Sample Unit Artifacts . . . . . . . . . . . . . . . . . . . . . 74

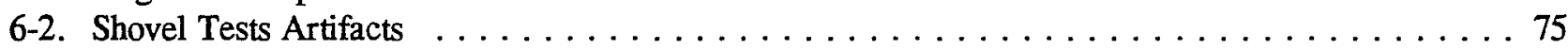

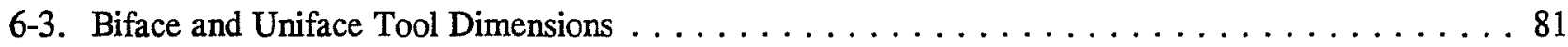

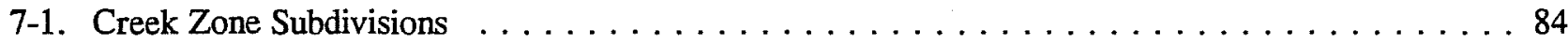

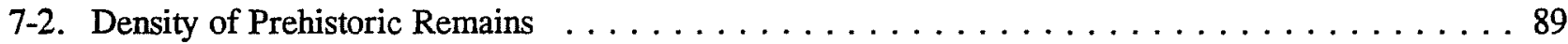

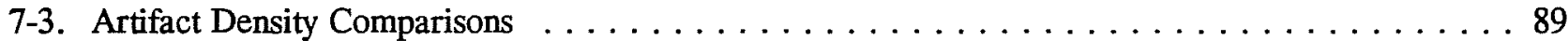

9-1. Dogleash-Unit Inventory for Site 41VV1654, Feature C. . . . . . . . . . . . . . . . 117

9-2. Dogleash-Unit Inventory for Historic Site 41 VV1682 . . . . . . . . . . . . . . . . . 125

10-1. Recorded and Collected Historic Artifacts . . . . . . . . . . . . . . . . 126

11-1. Site Summary . . . . . . . . . . . . . . . . . . . . . . . . 138

12-1. Initial Assessments for NRHP Eligibility . . . . . . . . . . . . . . . . . . . . . . . 142

12-2. Archaeological Site Testing Methods Recommended for Data Retrieval Design . . . . . . . . . 144

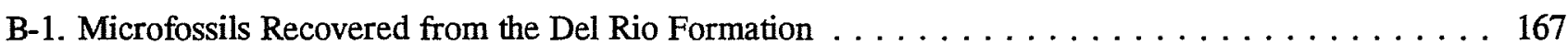

B-2. Megafossils in the Del Rio Formation . . . . . . . . . . . . . . . . . . . . . . 169

B-3. Microfossils Recovered from the Buda Formation $\ldots \ldots \ldots \ldots \ldots \ldots \ldots \ldots$

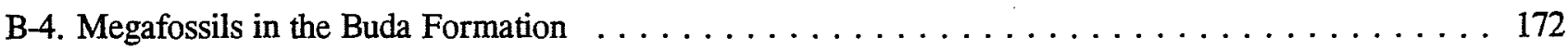

B-5. Mega- and Microfossils in the Salmon Peak Formation (Lake Amistad Marina) . . . . . . . . 173 


\section{ACKNOWLEDGMENTS}

The staff members at CAR wish to express their sincere appreciation to the military and civilian staff at Laughlin Air Force Base for their enthusiastic support during each phase of this project. The attitude of "doing what is right" begun by Brigadier General Kenneth W. Hess, former commander of the 47th Flight Training Wing, and continued by his successor Col. Timothy A. Peppe established an atmosphere of cooperation that was echoed throughout the base. Members of the 47th Support Group headed by Col. Robert Barlow, former commander, Col. Carl Critchlow, commander, and Lt. Col. Roger B. Condit, deputy commander, supplied our field crew with technical support and equipment that enhanced our effectiveness. S. M. Sgt. Jefferies and the other members of the 47th Security Police Squadron kept in touch with our teams by radio, making us feel secure and twice saving us from torrential storms with their thoughtful and timely warnings. Our closest dealings were with the staff of the 47th Civil Engineer Squadron. The support from former commander Lt. Col. Paul W. Somers and present commander Maj. Hal M. Tinsley was put into action by Donnie Stillwell, Abe Lincoln, Jim Brown, and John Strange. Special thanks are due to Monica Fields, former chief environmental officer and to John Scarbrough, our patient and fearless backhoe operator. But most of all, thanks to Ralph A. Mitchell, Jr., our primary contact, who expedited all our requests, answered all our questions, and made everything work smoothly. The total support shown by the personnel at Laughlin Air Force Base made this project a pleasure from start to finish.
Our appreciation extends to people off the base as well. The staff at the Whitehead Memorial Museum in Del Rio enthusiastically supplied information and photographs for this report. Florence Marshall Major and Anselyn Marshall graciously provided many of the photographs and family memories of pre-Laughlin life on the Zacatosa Ranch that appear in this report. And Steve De Vore with the National Park Service and Joe Labadie, archaeologist at Amistad National Recreation Area, shared their knowledge of the area.

Sandy Billingsley, Florencio Delgado, Kevin Gross, Barbara Meissner, Dave Nickels, Gerry Raymond, and Cynthia Tennis made up the Laughlin field team under the leadership of A. J. Taylor, project archaeologist, and Dr. Robert J. Hard, principal investigator. 


\section{Chapter 1. Introduction}

\section{Cynthia L. Tennis}

The Center for Archaeological Research (CAR) of The University of Texas at San Antonio (UTSA) conducted a pedestrian survey at Laughlin Air Force Base (AFB) and the Air Force Recreation Area and Marina, in southeastern Val Verde County, Texas (Figure 1-1). This archaeological baseline survey was conducted under National Park Service Contract
No. 1443-CX-200-94-005 to assist the U.S. Air Force in meeting its responsibilities under federal cultural resource laws and mandates (see National Park Service [NPS] 1993). Access to Laughlin AFB was coordinated through Mr. Ralph Mitchell, the base historic preservation officer (BHPO).

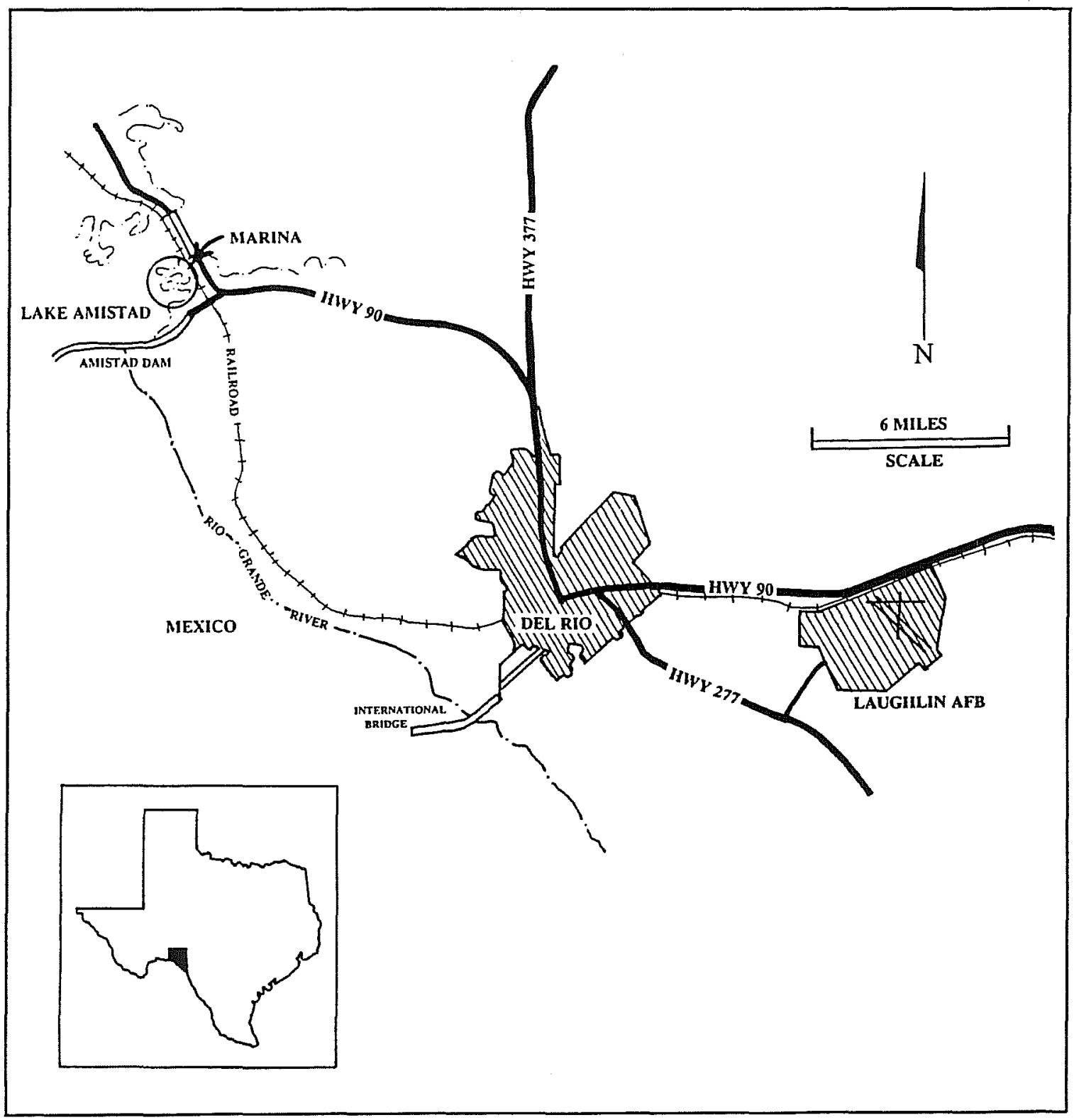

Figure 1-1. Laughlin AFB location map. 
The project had six major objectives.

1) To conduct a baseline, 100-percent pedestrian survey of approximately 2,855 acres within Laughlin AFB and the 45-acre Air Force Recreation Area and Marina to locate and record cultural resources.

2) To conduct a thorough literature and archival review to determine the probable nature and distribution of cultural resources within the project area.

3) To investigate land-use and subsistence patterns through analysis of site type, size, distribution, and artifact assemblage.

4) To make cultural resource recommendations of eligibility for nomination to the National Register of Historic Places.

5) To conduct limited paleontological resource investigations within the project area.

6) To conduct a limited geomorphological study of the project area.

While much has been written about prehistoric occupations in the Lower Pecos region of Texas, the majority of our knowledge comes from investigations centered in and around the major rivers and canyons. The survey and limited surface and subsurface testing at Laughlin AFB offered an opportunity to examine land-use patterns and site function of both historic and prehistoric sites in a setting removed from the canyons.

Thirteen archaeological sites were recorded on Laughlin AFB, three by De Vore (1993) and 10 during this phase of investigation. Of these 13 sites, 11 (41VV1653, 41VV1655, and 41VV1683-1691) were composed of prehistoric components. Diagnostic projectile points representing Late Paleoindian through Late Prehistoric occupations were recovered from five of these sites. One historic site (41VV1682) consists of remnants of the headquarters of the Zacatosa Ranch which occupied the immediate area from the 1920 s to the 1940 s when the property was bought for use by the military. One site (41VV1654), recorded by De Vore (1993), has a large prehistoric component-Late Paleoindian to Early Archaic-as well as a historic component associated with the Zacatosa Ranch and an earlier, possibly pre-1900, artifact scatter. Artifact types and densities were recorded and shovel tests were excavated at each of the 13 sites. Thirteen isolated finds were also recorded, 10 consisting of prehistoric cultural material, one (41VV1652) with prehistoric and historic material (De Vore 1993), and two with historic material. Site 41VV427, previously recorded at the Air Force Recreation Area and Marina, was not relocated during this survey.

Based on the results of this survey, seven prehistoric sites (41VV1685-1691) located at the south end of the north-south runway, three sites along the eastern edge of the base (41VV1654, 41VV1655, and 41VV1683), and one site (41VV1653) in the northwest corner of the base are recommended as eligible for nomination to the National Register of Historic Places under Criterion D. The 11 sites comprise a series of open sites within the base's two riverine environments that span the Paleoindian through Late Prehistoric time periods. Minimal research has been undertaken and little is understood concerning the role of open sites away from the canyons and major rivers in the Lower Pecos. Consequently these sites have the potential to offer data on changing patterns of hunter-gatherer mobility, subsistence, and landuse adaptations in this region. 


\title{
Chapter 2. Project Area
}

\section{LOCATION AND ENVIRONMENT}

\author{
Gerry R. Raymond
}

Laughlin AFB and the Air Force Recreation Area and Marina, comprising approximately 4,110 acres and 45 acres respectively, are located in the southeastern part of Val Verde County, Texas (Figure 1-1). The base is situated about $8 \mathrm{~km}$ east of Del Rio, Texas. The recreation area is 10 to $11 \mathrm{~km}$ northwest of Del Rio, overlooking the Devils River and Amistad Reservoir.

The project areas are within the physiographic region designated the Lower Pecos canyonlands (Black 1989) and within the archaeological area referred to as the Lower Pecos River region (Bement 1989; Turpin 1991). The latter centers on the confluence of the Pecos and Devils rivers and the Rio Grande, and includes most of Val Verde County.

\section{MODERN ENVIRONMENT}

\section{CLIMATE}

The climate in the study area is semi-arid, with an average annual rainfall of $44 \mathrm{~cm}$. Rainfall occurs seasonally, with $35 \mathrm{~cm}$ falling from April through October and $9 \mathrm{~cm}$ from November through March. The mean temperature is $70^{\circ} \mathrm{F}$, with average temperatures ranging from $51^{\circ} \mathrm{F}$ in January to $86^{\circ} \mathrm{F}$ in July. The growing season averages 300 days, with the frost period running from December 9 to February 12 (Natural Fibers Information Center 1987). The effective temperature, which is a measure of the amount and distribution of the annual solar radiation over a defined area of the earth's surface-and a primary indicator of seasonality(Bailey 1960), is $15.8^{\circ} \mathrm{C}$ at Del Rio.

The net primary production for the Del Rio Quadrant \#155, as calculated by Owen and Schmidly (1986), is $512 \mathrm{~g} / \mathrm{m}^{2} /$ year. Based on Kelly's (1983) regression equation for arid environments, the area has an estimated primary biomass of $1.5 \mathrm{~kg} / \mathrm{m}^{2}$. Net primary production is the amount of energy produced annually from photosynthesis after respiration (Kelly 1983) and generally equates to the amount of new growth of vegetation each year. Primary biomass is the dry weight of the total standing (above ground) vegetation present at a given time (Whittaker et al. 1975).

\section{BIOTIC RESOURCES}

Three major biotic provinces merge in the general region surrounding Laughlin AFB, providing a unique nexus of vegetal resources. These provinces are presented below.

1) Tamaulipan thorny brushlands, a semi-arid megathermal area (Blair 1950:102; Dice 1943), characterized as a mesquite-chaparral zone (Chadderdon 1981).

2) Chihuahuan shrubs and grasses in an aridadapted environment (Blair 1950: 105; Dice 1943), characterized as a sotol-lechuguilla zone (Chadderdon 1981).

3) Balconian, a juniper-oak associated scrubforest zone (Blair 1950:113).

The vegetative diversity of the region may be further enhanced by the high relief of the deeply incised canyons and arroyos, resulting in the juxtaposition of a variety of habitats and their associated moisture availability (Flyr 1966).

Consistent with the region's ecotonal position, Flyr (1966:33-38) characterized the area by its vegetative 
diversity and, based on his field observations in 1965-1966, described four vegetative habitats.

1) Vega-terrace vegetation in the canyons of the Pecos River, the Rio Grande and the lower Devils River; although the vegetation is near permanent water, some species on the upper terraces are not mesic related.

2) Cliff-canyon vegetation in areas of thin or no soil cover in the steep, narrow side canyons that lead into the major streams; xeric-adapted plants are found on the upper, dry parts of the canyons and surrounding hills.

3) Upland hills vegetation on the upland rocky hills with various areas populated by scattered xeric-adapted plants that do not require much soil development.

4) Upland flats vegetation in the areas with some soils lying between the rocky hills. This vegetation is largely xeric adapted but requires some soil development.

Within the above described environmental context, the Air Force Recreation Area and Marina is located on the upland rim of arroyos filled with water from Amistad Reservoir, which most closely conforms to Flyr's (1966) upland hills vegetation habitat. The surface is largely Cretaceous limestone with little, if any, soil development and is covered with cacti, succulents such as agave and lechuguilla, small mesquite trees, and thorny scrubs.

Laughlin AFB is located in the interior uplands of the Lower Pecos region, about $9.7 \mathrm{~km}$ east of the Rio Grande. The terrain is gently rolling, rather than the high relief of the canyonlands. The base is cut by two low-order, perennial streams: Zorro Creek in the extreme northwest part of the base, and Sacatosa Creek which runs along the eastern boundary and through the southeast part of the base. Between the two creeks is an expanse of about $4 \mathrm{~km}$ of low hills and flats with some areas of valley fills. The elevations range from about $341 \mathrm{~m}$ near the center of the base, to $320 \mathrm{~m}$ along Zorro Creek and $311 \mathrm{~m}$ along the Sacatosa.

No terraces are found along Zorro Creek; instead, gently rising valley walls of Cretaceous limestones flank the Holocene valley-filled floodplain. Sacatosa
Creek and its floodplain (T0) are bordered on the west by a gradually sloping terrace (T2) in the upper portion of the creek, with bluffs of bedrock strata that rise $10-12 \mathrm{~m}$ above the creek in the southern portion of the base. Three short, transverse gullies cut the bedrock bluffs and drain into the creek. Another low, gently rising terrace (T1) is situated on the east side of the creek; however, only a short portion of that terrace is within the base boundary.

The inland terrain generally conforms to Flyr's (1966) upland hills and flats vegetative habitats. The creek-associated area generally conforms to the vega-terrace zone, but is more limited in extent as the base does not offer the vertical transitions seen in the canyonlands. The three short gullies cutting the west terrace contain upland hills vegetation rather than the cliff-canyon vegetative community described by Flyr (1966). There is one small seep, however, near the head of one of the gullies that does support some mesic-adapted vegetation.

Within the context of Flyr's vegetative habitats, two biotic zones were observed on the base. One vegetal association occurs along the creeks and the associated flood plains and lower terrace areas, the other community populates the upper terrace areas and the upland hills and flats. The vegetation near the permanent water and drainages in the terraces is occasionally dense, includes mesic-adapted species not seen elsewhere in the project area, and generally is not stunted as is the scrub growth farther from the floodplains and in the uplands. However, in some areas along the creek and on the lower terraces grazing has severely affected the vegetation.

The vegetation in the creek-associated zone includes large mesquite trees (Prosopis glandulosa), thick stands of switchgrass (Panicum virgatum), reeds, yaupon (Ilex vomitoria), sunflower (Helianthus annus), greenbriar (Similax sp.), desert hackberry (Celtis pallida), guayacan (Guaiacum angustifloium), chapote or Texas persimmon (Diospyros texana), whitebrush (Aloysia gratissima), scattered cacti such as Texas prickly pear (Opuntia engelmannii) and tasajillo (Opuntia leptocaulis), and some acacias and cenizo (Leucophyllum frutesens). Much of the cacti, acacia, and cenizo present on the floodplain and lower terraces are in areas where large mesquite trees are fairly close to Sacatosa Creek and the surface has been denuded by grazing. 
The vegetation farther from the streams on the higher part of the terraces and the upland hills and flats is dominated by xeric varieties of thorny and woody scrub brush species. Cenizo and acacias, such as blackbrush (Acacia rigidula), catclaw (Acacia greggii), and guajillo (Acacia berlandieri) are the most prominent types of plants. These are accompanied by short and medium grasses such as tobosa (Hilaria mutica) and curly mesquite (Hilaria blageri), fall witchgrass (Digitaria cognata), buffalograss (Buchlo dactyloides), Texas paloverde (Parkinsonia texana), crucifixion thorn (Koeberlinia spinosa), scattered prickly pear, tasajillo, and strawberry cactus (Echinocereus enneacanthus). Century plants (Agave americana) and maguey (Agave scabra) are present but not common. The mesquite trees in the area are scattered and stunted.

The ecological and economic evolution of the region is a significant factor in the assessment of the biotic resources relative to prehistoric settlement and subsistence activities. The regional and local landscape has been significantly altered due to damming of the Rio Grande, denuding of the grasslands through overgrazing, and by modern land use practices such as military training operations. The presence of more extensive grasslands in the interior uplands prior to European contact is supported by palynological evidence and by accounts of Spanish explorers and early ranchers (Williams-Dean 1978).

Although geomorphological evidence reflects episodes of prehistoric flooding and erosional activity (Kochel 1982), surface runoff rates may have been considerably less than in the Historic period, and the ecological and archaeological implications of these differences should be considered. Several plant species found in the area, such as Bermuda grass (Cynodon dactylon), salt cedar (Tamarisk sp.), and tree tobacco (Nicotiana glauca), are not indigenous but were introduced by Europeans (Flyr 1966).

The diversity of the extant faunal species parallels that of the vegetation, again because of the ecological dynamics of the convergence of the three major biotic provinces in the Lower Pecos region. Word and Douglas (1970) list over 50 species of mammals, including whitetail deer (Odocoileus virginianus), bobcat (Lynx rufus), fox (Vulpes sp.), coyote (Canis latrans), opossum (Didelphis virginianus), javelina (Peccari angulatus), raccoon (Procyon lotor), porcupine (Erethizon dorsatum), skunk (Mephitis mephitis), armadillo (Dasypus novemcinctus), mice (Peromyscus sp. and Onychomys sp.), squirrels (Sciurus sp.), jackrabbit (Lepus californicus), cottontail rabbits (Sylvilagus sp.), and other rodents. Larger mammals such as bear (Ursus sp.) and pronghorn (Antelocapra americana) were found in earlier historic times (Word and Douglas 1970). Reptiles include many species of turtles, lizards, and snakes. Several species of fish including gar (Lepisosteus sp.), catfish (Ictalurus sp.), bass (Roccus sp.), sunfish (Orthagoriscus sp.), and perch (Perca sp.) have been identified in the rivers and intermittent streams. Field guides and manuals list many bird species that are either year-round or seasonal inhabitants of the region, including raptors and many smaller species (Robbins et al. 1963).

\section{SOILS}

The soil cover for the base and the marina is analyzed using the Soil Conservation Service's soil map units (Golden et al. 1982). Each soil map unit covers an area with a unique natural landscape that has a distinctive pattern of soils, relief, and drainage. Laughlin AFB is located in what is termed the Olmos-Acuna-Coahuila unit. Those soils are the major components of the area and are very shallow to deep, nearly level to sloping ( 0 to 8 percent) soils, on uplands and terraces of the Rio Grande Plain. These are generally clayey and loamy soils that are gravelly. The soils with the largest surface areas on the base are the Zapata-Vinegarroon complex (clay loam and gravelly loam), Acuna silty clay, and Olmos very gravelly loam. Tobosa clay lies along Zorro Creek on the west side of the base and Pintas clay lies along Sacatosa Creek. The two creek zones have areas of colluvial and alluvial deposits that may contain buried sites (see Nordt, this chapter).

The marina recreational area is located in the Langtry-Rock outcrop-Zorro map unit which consists of exposed limestone bedrock and very shallow to shallow, loamy soils that are cobbley and stony. The unit consists of gently rolling to very steep soils ( 1 to 60 percent) on plateaus and steep canyons. 


\section{PALEOENVIRONMENT}

Although the paleoenvironmental conditions for many areas of South Texas are not well understood (Black 1989), a sufficient data base for modeling the Lower Pecos region's paleoenvironment has been accumulated. Data sets have been built from the numerous archaeological investigations in the region resulting from the Amistad Reservoir salvage work and the interest in the area's rock art. The excellent preservation conditions in the arid environs and the protected rock shelters have contributed to the successful collection of palynological, paleontological, geomorphological, macrobotanical, bioarchaeological, coprolite, and stable-isotope data.

Based largely on the fossil pollen record from Lower Pecos archaeological sites such as Bonfire Shelter, the Devil's Mouth site, Eagle Cave, and Hinds Cave, Bryant and Holloway (1985) present a postPleistocene environmental reconstruction for southwest Texas. They suggest a general drying and warming trend beginning about 8,000 years ago with the initiation of the post-glacial period. Evidence from packrat middens from the Big Bend area supports this view of a relatively drier climate with increased summer temperatures and warmer winters (Van Devender 1990). This trend toward increasing aridity replaced the parkland areas of piñon and juniper with semi-arid shrub grassland and desert species. Dering's $(1977,1979)$ analyses of pollen and macro-plant remains from Hinds Cave and Baker Cave indicate that by 8500 B.P., agave, yucca, sotol, and various cacti (Opuntia), all associated with xeric environments, appeared in the archaeological record. Dering (1979) also notes a decrease in pine pollen percentages while the composite pollen percentage increased from the late glacial period.

Little pollen evidence is available from the period from about 7000-4000 B.P. (note: this period corresponds temporally with Antevs's Altithermal [Brown 1991]), but Johnson's (1963) analysis of small samples recovered from Centipede and Damp caves suggests no major changes in vegetation or climatic conditions for that period. Bryant and Holloway (1985:56-57) use Johnson's analysis, together with the coprolite (Williams-Dean 1978) and faunal analyses (Lord 1984) from Hinds Cave, to conclude that from about 7000-4000 B.P., the Lower Pecos region was becoming increasingly xeric. Dering (1979) again suggests a decrease in pine pollen frequencies with the nonarboreal pollen species dominating over the arboreal pollen types. This is also a period during which the geomorphological record shows intervals of severe flooding and erosional activity (Patton and Dibble 1982).

Bryant and Holloway (1985) further postulate that for the last 4,000 years the warming and drying trend gradually continued with only a short mesic episode about 2,500 years ago. This conclusion is based on a large bison kill at Bonfire Shelter and pollen analysis from the Devil's Mouth site. Thus during the last $4,000-5,000$ years, desert scrub communities were established and grasslands, xeric scrubs, and succulents became prominent and dominated the Lower Pecos landscape (Dering 1979; Van Devender 1990).

Most interpretations of the paleoenvironmental evidence suggest that a suite of resources similar to those available today was exploited, with a shift through time to more reliance upon xeric plant species. The determination of the percent contributed by the various plant and animal species to the prehistoric diet is still problematic, but there is evidence of the changing role of specific resources, such as bison and grass seeds.

The availability of water may have been a limiting factor on the mobility and settlement patterns for prehistoric groups in the semi-arid environment of the Lower Pecos. Surface water is scarce except for the three major rivers which provide permanent water supplies. The Devils River is unique among the three in that, unlike the Rio Grande and the Pecos River, it is not fed by precipitation runoff originating far upstream, but is principally supplied by discharge from a regional limestone aquifer.

While side canyons and arroyos carry water runoff only after rains and during flooding, many beds of these tributaries and side canyons have bedrock solution cavities (tinajas), some of which are fed by seep springs. Such tinajas can retain water for extended periods after the rain runoff (Mallouf and Tunnell 1977; Word and Douglas 1970). Although a systematic inventory of springs is not found in the literature, numerous references to permanent springs and seeps such as those near Baker Cave (Word and Douglas 1970) and in Seminole Canyon (Turpin and Bement 1985) are available. San Felipe Springs in Del Rio is a group of 10 springs with an average 
daily discharge of $247,000 \mathrm{kl}(65,000,000 \mathrm{gal})$, a significant water source which provides water to Laughlin AFB via a pipeline (Labadie 1986). Along with the Devils River, springs and tinajas in the area provide a reliable water source (Brown 1991).

\section{GEOLOGY}

Both the lower Edwards Plateau and the upper Rio Grande Plain in Val Verde County are developed primarily on sedimentary Cretaceous-age limestones and marls deposited under marine conditions. The Salmon Peak Limestone and Lower Cretaceous Del Rio Clay (shale and siltstone rocks) are overlain by Lower Cretaceous Buda Limestone. The Austin Chalk (hard-lime mudstone to soft chalk) is the last of the Cretaceous-aged sediments and these strata crop out in various areas of Val Verde County. The only Tertiary deposit in the area is the Uvalde Gravel, a Pliocene-aged alluvium deposit of calichecemented, mixed gravels dominated by chert and other siliceous clasts (Abbott 1991; Golden et al. 1982). Pleistocene- and Holocene-aged material is river-deposited sediments forming fluvial terraces, alluvial fans, and colluvium of calcareous gravel, sand, silt, and clay, and beds of caliche in some areas (Golden et al. 1982). 


\title{
GEOMORPHOLOGICAL INVESTIGATIONS
}

\author{
Lee C. Nordt
}

\section{INTRODUCTION}

The objectives of the geoarchaeological investigations within the project area were to: 1) identify and establish the chronology of the major late Quaternary stratigraphic units; 2) interpret environments of deposition; and 3) assess preservation and recovery potentials for the archaeological record as influenced by the geomorphic record.

\section{METHODS}

Thirteen backhoe trenches and one gully exposure were described in the project area. Standards and procedures for writing soil-stratigraphic descriptions followed those of the Soil Survey Staff (1981) and Holliday (1990). Stratigraphic units were defined as packages of sediments bound by disconformities and labeled I-IV, from oldest to youngest. Landforms were designated as $\mathrm{T} 2, \mathrm{~T} 1$, and $\mathrm{TO}$, from oldest to youngest. $\mathrm{T} 2$ and $\mathrm{T} 1$ are terrace designations, while TO refers to the active floodplain.

Charcoal samples were not available for carbon-14 dating; therefore three carbon-14 assays were done on bulk humate samples. While these ages seem reasonable and are taken to represent the time of alluvial deposition, post-depositional processes such as fluctuating water tables and plant roots can contaminate humate ages more so than charcoal. Further carbon-14 dating would be needed to verify the late Quaternary chronological framework in the project area. Carbon-14 assays were done by Beta Analytic, Inc. Ages are reported in years before present (B.P.) and corrected for variations in $\partial^{13} \mathrm{C}$.

Unless otherwise noted, cultural divisions and time periods follow those proposed by Turpin (1991) for the Lower Pecos region.

\section{GEOMORPHIC OVERVIEW}

The northwest corner of the project area is mapped as Upper Cretaceous limestones and clays (Barnes 1977). Most of the remaining area is mapped as the Pliocene/Pleistocene Uvalde Gravel. The Uvalde Gravel consists of caliche-cemented cherts and limestones deposited by ancestral streams having no relation to the modern tributary network. Thickness ranges from surface outcrop to $10 \mathrm{~m}$.

Two low-order streams, both tributaries of the Rio Grande to the south, bisect the study area. Sacatosa Creek flows along the eastern margin of the study area, while Zorro Creek flows through the northwest corner. Both floodplains are poorly drained and have high water tables during the spring and fall of each year. The downstream gradients of Sacatosa and Zorro creeks are about $2 \mathrm{~m} / \mathrm{km}$ and $3 \mathrm{~m} / \mathrm{km}$, respectively.

Olmos very gravelly loam soils have developed in the Cretaceous units, while the Zapata-Vinegarroon complex and Acuna clay soils have developed in the Uvalde Gravel and upland valley fills, respectively (Golden et al. 1982). The Sacatosa floodplain is mapped as the Pintas clay frequently flooded, and the Zorro Creek floodplain as the Acuna clay (Golden et al. 1982). While useful as general guidelines, the soil survey maps do not contain the information needed to identify culturally relevant deposits with confidence.

\section{UPLAND STRATIGRAPHY}

Trenches 1 and 2 were excavated in colluvial upland valley fills (Figures 2-1 and 2-2; Appendix A). The trenches expose stratigraphic Unit I and a Holocene undifferentiated unit. Unit I consists of an upper Bkm horizon with stage 4 carbonate morphology (indurated $\mathrm{CaCO}_{3}$ ) and a lower $\mathrm{Bk}$ horizon 


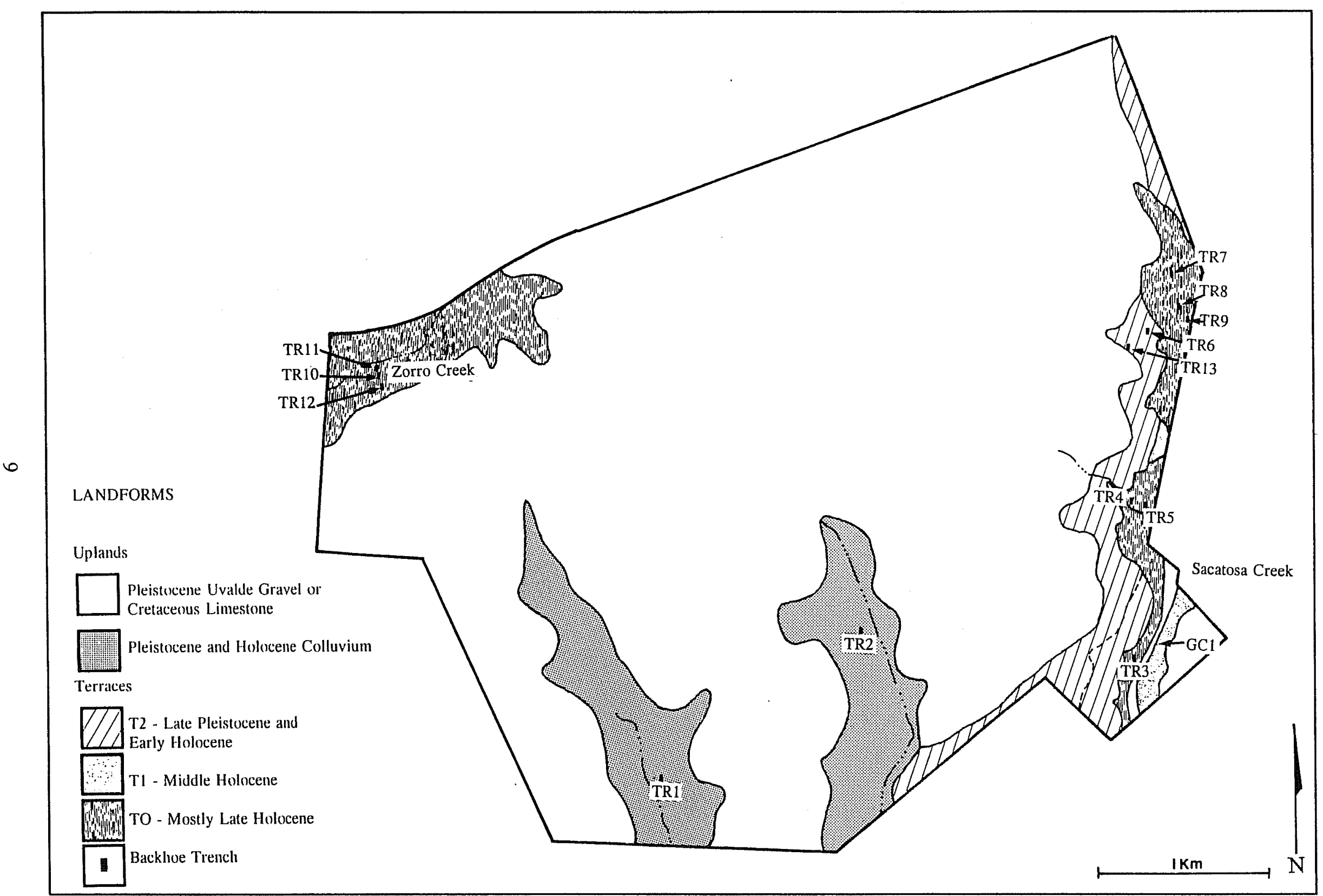

Figure 2-1. Map of the project area showing soil description localities and landforms. $\mathrm{TR}=$ trench location; $\mathrm{GC}=$ gully cut. 
with stage 2 carbonate morphology (nodular $\mathrm{CaCO}_{3}$; Gile et al. 1966). The degree of carbonate development suggests the sediments would be at least late Pleistocene age in both east-central New Mexico (Gile et al. 1966) and central Texas (Blum and Valastro 1989).

The Holocene undifferentiated unit consists of a loamy colluvial veneer burying Unit $I$ in each of the two trenches. This unit is calcareous and exhibits weak pedogenesis; thus, it is assigned a Holocene age. Trench 1 contains a gravelly colluvial wedge on the upslope end of the trench that laterally grades to the fine-grained Holocene undifferentiated unit on the downslope end of the trench (Figure 2-2). Lateral grading indicates that these colluvial facies are coeval and extend upslope to the local interfluves. Sediments in Unit I and the Holocene undifferentiated unit are derived locally from the Uvalde Gravel.

\section{SACATOSA CREEK STRATIGRAPHY}

Sacatosa Creek is bordered by three major fluvial landforms: terrace 2 (T2), terrace 1 (T1) and the modern floodplain (TO) (Figures 2-1 and 2-2). T2 is situated at an elevation between 320 and $323 \mathrm{~m}$ $(1,050$ and $1,060 \mathrm{ft})$ in the upper part of the drainage basin and between 316.9 and $320 \mathrm{~m}(1,040$ and $1,050 \mathrm{ft}$ ) in the lower part. In the south section of the project area, $\mathrm{T} 2$ consists of a bedrock strata veneered by channel lag. Most of T2, however, is underlain by at least two meters of alluvium, which is typified by the exposure provided in Trench 6 (Figure 2-3; Appendix A). The lower unit in this trench has a Bk horizon characterized by stage $2 \mathrm{CaCO}_{3}$ morphology, suggesting a Pleistocene age. Consequently, this unit may be correlative with Unit $I$ in Trenches 1 and 2 . Apparently T2 of Sacatosa Creek was the base levelcontrolling floodplain to which many local upland valleys were grading in the Pleistocene.

The upper 45 to $50 \mathrm{~cm}$ in Trench 6 consists of a calcareous, loamy $\mathrm{A}-\mathrm{Bw}$ horizon sequence designated as Unit II (Appendix A). A Golondrina point (9400-8800 B.P.) was discovered at a depth of $33 \mathrm{~cm}$ in a pit about $200 \mathrm{~m}$ north of Trench 6 on the northern boundary of site 41VV1654 (see Chapter 6 for artifact descriptions). This depth would place the point in the lower part of Unit II in Trench 6 . Assuming this point was not transported by bioturbation, aggradation of the T2 floodplain was still ongoing between 9400 and 8800 B.P. However, if the point was originally on the ground surface and subsequently bioturbated downward, T2 would have been in place by as early as 9400 B.P. Wilson and Gower points (8900-5500 B.P.) found on the surface of $\mathrm{T} 2$ indicate that its construction had definitely ended and the floodplain was available for human occupation by as early as 8800 B.P. Units I and II are relatively fine grained; however, Unit II has less silt and more sand than Unit I. Therefore, the sequence coarsens upward and may signify a shift in flow regime or possibly to wind-blown aggradation. In either case, the aggradational timing of Unit II may coincide in part with an early Holocene mesic 
interval characterized by fine-grained sedimentation along the Pecos River (Patton and Dibble 1982).

Sacatosa Creek incised about 9 to $10 \mathrm{~m}$ shortly after 8800 B.P., apparently in response to an early Holocene warming trend documented in both southwest Texas (Bryant and Holloway 1985) and in central Texas (Bryant and Holloway 1985; Nordt et al. 1994). This period of erosion slightly post-dates widespread stream channel trenching documented in central Texas between 15,000 and 11,000 B.P. (Blum and Valastro 1989; Nordt 1992). The Sacatosa Creek channel at this time became deeply scoured into the basal Uvalde Gravel beneath TO (Figure 2-3, Trench 4).

Deposition of Unit II within the floodplain of Sacatosa Creek began shortly after the early Holocene channel-trenching episode. Unit II in Trench 4 is characterized by a weak stage 2 , truncated $\mathrm{Bk}$ horizon (Appendix A). Based on a carbon14 age from Unit III along Zorro Creek (Trench 10, to be discussed later), deposition of Unit II along Sacatosa Creek had ended by 6500 B.P. It is tentatively assumed that Unit II beneath $\mathrm{T} 2$ is an eolian facies deposited coevally with the Unit II floodplain facies in Trench 4.

$\mathrm{T} 1$ of Sacatosa Creek is situated between the 310.9 and $396.2 \mathrm{~m}(1,020$ and 1,300 ft) contours on the southeast side of the project area (Figure 2-1). The oldest point discovered on $\mathrm{T} 1$ is either a Bandy or a Martindale. Turpin (1991) places the Bandy in the Early Archaic (Viejo period) between 8900 and 5500 B.P. in the Lower Pecos region and Turner and Hester (1993) place it in the Early Archaic between 8000 and 6000 B.P. Turner and Hester (1993) place the Martindale point in the Early Archaic, but without date brackets, while Prewitt (1985) places it between 6100 and 5100 B.P. in central Texas. These age estimations correlate closely with ongoing deposition of Unit III on Zorro Creek around 6500 B.P. Consequently, deposition of Unit III and construction of T1 on Sacatosa Creek probably did not begin much earlier than this.

Erosion just before or during deposition of Unit III removed most of Unit II except in the deep channel scour shown in Trench 4 (Figure 2-3). The graveliferous nature of Unit III, as exposed in Gully Cut 1 (GC1) (Appendix A), indicates that high magnitude flood events were occurring in this basin during the middle Holocene. Similar interpretations have been made for the middle Holocene in the Lower Pecos region (Patton and Dibble 1982) and in central Texas (Nordt 1992).

Aggradation of Unit III ended with a period of channel erosion in the latter part of the middle Holocene that left $\mathrm{T} 1$ as a terrace. This episode of erosion in the project area may correlate with the Ozona erosional episode that occurred sometime between about 4500 and 3500 B.P. along the lower Pecos River (Patton and Dibble 1982), and with widespread channel erosion documented in central Texas between 5000 and 4000 B.P. (Blum and Valastro 1989; Nordt 1992). This erosional event may have occurred in response to a middle Holocene warm/dry interval recorded in central Texas (Nordt et al. 1994; Toomey et al. 1993).

A carbon-14 age from Trench 4 in the TO floodplain shows that aggradation of Unit IV was underway by $3320 \pm 70$ B.P. (Beta 73178) (Figure 2-3). Here Unit IV represents a fine-grained alluvial fan deposit unconformably overlying Unit II (Figure 2-1; Appendix A). As revealed in Trench 13, these fan deposits begin on $\mathrm{T} 2$ as one-meter-thick gully-fills truncating and burying the $\mathrm{Bk}$ horizon correlated with Unit I in Trench 6 (Appendix A). The soil developed in both the gully-fills and fans of Unit IV exhibits a weakly developed A-Bw horizon sequence, substantiating a late Holocene age (Appendix A). According to carbon-14 ages from Trenches 4 and 5, another period of channel erosion occurred between 3320 and $1750 \pm 70$ B.P. (Beta 73179) (Figure 2-3). In the project area this erosional event removed most of the fan and floodplain deposits of Unit IV. Nordt (1992) documented widespread channel erosion in central Texas within this interval and attributed it to a brief warm/dry interval that occurred around 2000 B.P. Interestingly, this period of erosion roughly corresponds with an interpreted mesic interval between 3000 and 2000 B.P. in the lower Pecos region (Patton and Dibble 1982). This interval was characterized by fine-grained deposition and low intensity flooding.

Aggradation of Unit V began by $1750 \pm 70$ B.P. and proceeded slowly until Historic times (Trench 5) (Figure 2-3). Bryant and Holloway (1985), Patton and Dibble (1982), and Nordt et al. (1994) all show no appreciable change in climate during the last 2,000 years, which coincides with slow and uniform stream aggradation along Sacatosa Creek. Most 


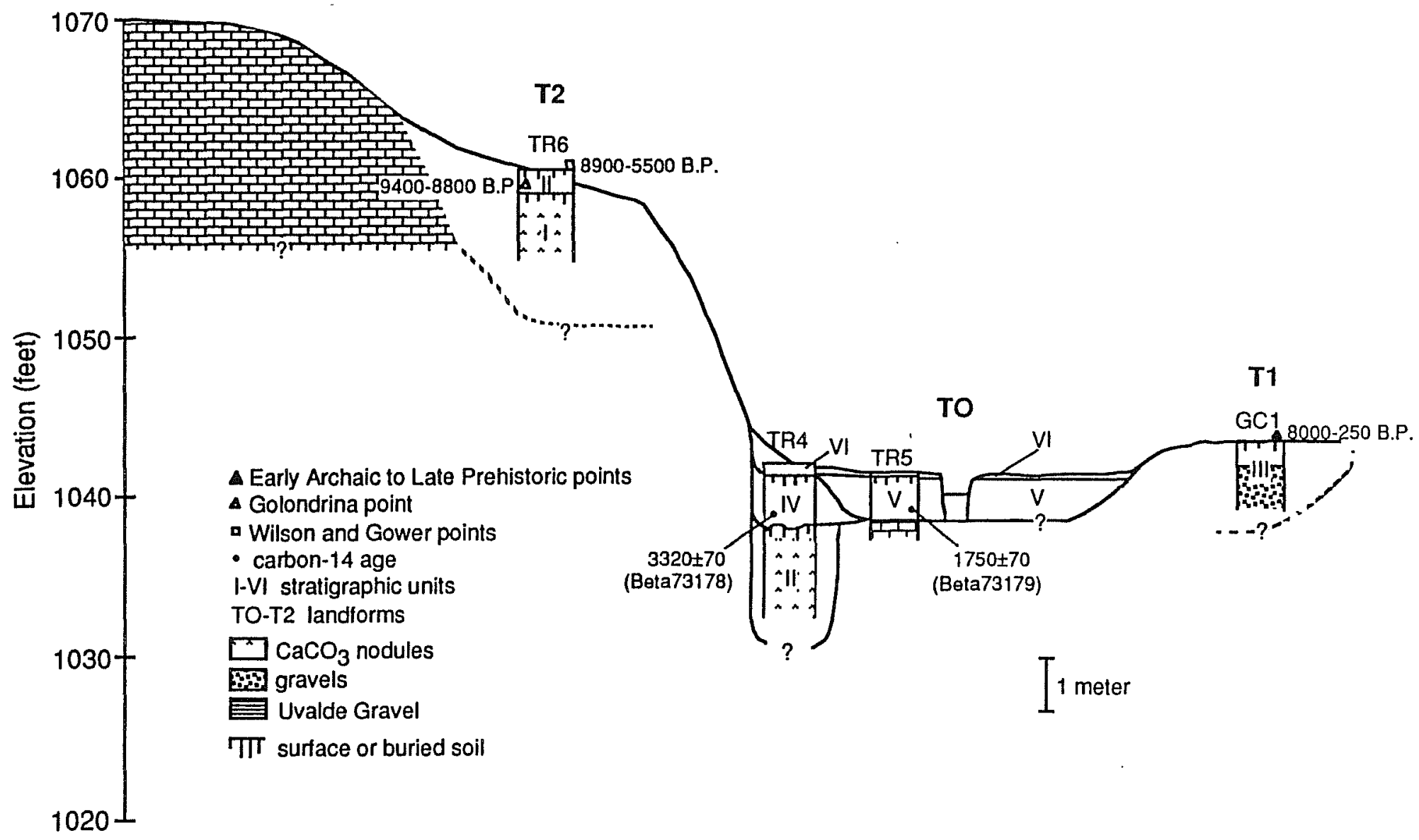

Figure 2-3. Composite stratigraphic cross-section of Sacatosa Creek based on selected trenches and gully exposures. See Figure 2-1 for horizontal locations. 
exposures show that Unit $\mathrm{V}$ is clayey (see Appendix A, Trenches 5, 7, and 8). However, graveliferous sediments in Trench 3 (Figure 2-1; Appendix A) of TO indicates that isolated coarse-grained meander belts are contained within widespread clayey floodbasin deposits. The soil developed in Unit V has a weakly developed A-Bg (gleyed) horizon sequence. Because the soil developed in the top of Unit IV exhibits no wetness features (redox), the modern high water table apparently became stable during aggradation of Unit V. Unit V in Trench 7 (Figure 2-1; Appendix A) suggests that fan aggradation was ongoing at this time also.

A light-colored, loamy layer about 5 to $15 \mathrm{~cm}$ thick covers most of the TO floodplain of Sacatosa Creek (Figure 2-3; see Appendix A, Trenches 5, 4, 7, and 8). This unit may have resulted from enhanced upland erosion during Historic times. This deposit is designated Unit VI.

\section{ZORRO CREEK STRATIGRAPHY}

No stream terraces are preserved adjacent to Zorro Creek (Figure 2-1). However, a carbon-14 age from Trench 10 (Figure 2-1; Appendix A) indicates that Holocene valley filling was occurring $6590 \pm 90$ B.P. (Beta 73180) (Figure 2-4). This age, and the ages of time-diagnostic artifacts on T1 of Sacatosa Creek, suggest that Unit III is chronologically correlative between the two basins. However, on Zorro Creek Unit III is finer grained, perhaps because of the shallower down-valley gradient and subsequent lower discharge velocities during the past. Unit III is also exposed in Trenches 11 and 12 (Figure 2-4; Appendix A) suggesting that middle Holocene valley filling was widespread along Zorro Creek. An isolated graveliferous channel deposit in Trench 11 shows that coarse sediments were confined to a coarse-grained meander belt, while most valley filling occurred by clayey floodbasin deposition. The presence of gypsum and the higher abundance of nodular $\mathrm{CaCO}_{3}$ in Trench 12 , compared to Trenches 11 and 10 , may be the result of lateral capillary wicking from a high water table near Trench 11 through the fine-grained Unit III sediments toward Trench 12. Gleyed colors in Unit III of Trench 11, accompanied by iron oxide pore coats, indicate that the ground water table adjacent to Zorro Creek is high for extended periods.

A late Holocene alluvial veneer buries Unit III in Trenches 10 and 11 , but pinches out before reaching Trench 12 in the outer half of the TO floodplain (Figures 2-1 and 2-4). If a channel facies exists with this veneer, it would be confined to the narrow modern meander belt of Zorro Creek. Although the landform near these trenches is mapped as TO, the veneer is mapped as a late Holocene undifferentiated unit. The exact timing of this period of deposition is unknown.

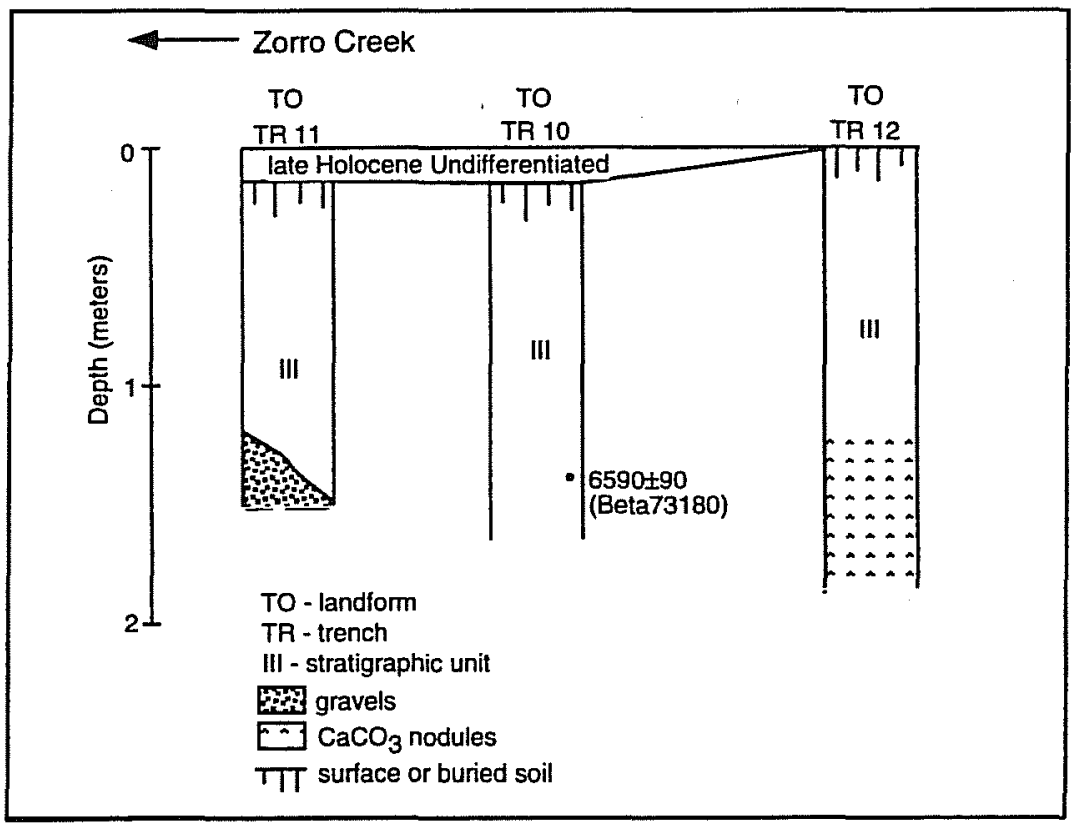

Figure 2-4. Composite stratigraphic cross-section of trenches from Zorro Creek. See Figure 2-1 for trench locations. 


\section{GEOARCHAEOLOGICAL INTERPRETATIONS}

\section{PALEOINDIAN (9400-8800 в.P.)}

The upland surfaces overlying the Cretaceous units and Uvalde Gravel may contain cultural sites spanning the entire known cultural record of the Lower Pecos region (Figure 2-1). Because of age and associated bioturbation, weathering, soil cracking, and human disturbance, Paleoindian sites will be difficult to locate in undisturbed contexts.

Associated with T2 and its underlying deposit and deeply buried beneath TO on the outer edge of Sacatosa Creek, Unit II is the most likely place to encounter buried Paleoindian sites (Figure 2-3). Both units appear to have accreted slowly, therefore, site-forming processes were conducive to site preservation. Recovery potentials for Paleoindian sites in Unit II of TO are low, however, because of the low volume of sediment preservation. Because of Holocene gully and sheet erosion, any cultural components found in site 41VV1685 on the southern part of $\mathrm{T} 2$ will probably be in secondary contexts.

\section{EARLY ARCHAIC (8900-5500 B.P.)}

Early Archaic sites can be found on the upland surface, and on T2 and T1 of Sacatosa Creek (Figure 2-1). Post-site-forming processes, however, may have altered components of these sites from their in situ contexts. Wilson and Gower points discovered on T2 and Bandy/Martindale, Pedernales, and Ensor points found on $\mathrm{T} 1$ show that these surfaces may contain sites ranging from Early Archaic to as late as the Late Prehistoric.

Buried Early Archaic sites will likely be located in the fine-grained alluvium of Unit III along Zorro Creek (Figure 2-4). Here slow, long-term aggradation made site forming processes amenable for site preservation. Only the upper $40 \mathrm{~cm}$ of Unit III beneath T1 of Sacatosa Creek may contain undisturbed Early Archaic sites (Figure 2-3). In fact, hearths can be observed eroding from this terrace near sites 41VV1686-1690. Any Early Archaic sites present in the lower graveliferous facies of Unit III will have been greatly disturbed by channel activity.

\section{MIDDLE ARCHAIC (5500-3200 B.P.)}

Middle Archaic components can be found on the upland surface, on T2 and T1 along Sacatosa Creek, and on the outer margins of TO along Zorro Creek where the late Holocene veneer does not bury Unit III (Figure 2-1). Buried Middle Archaic components will most likely occur 1) on Unit III along Zorro Creek buried beneath 10 to $15 \mathrm{~cm}$ of late Holocene overwash, and 2) in isolated alluvial fan deposits preserved along the outer valley wall of Sacatosa Creek. The gully-fills inset to and bisecting $\mathrm{T} 2$, and grading to the TO fan deposits on the west side of Sacatosa Creek, may also contain Middle Archaic components. Where these gullies cross site 41VV1654 on T2, only Middle Archaic and younger components may be observed.

\section{LATE ARCHAIC TO LATE PREHISTORIC (3200-250 B.P.)}

Late Archaic to Late Prehistoric components may be found on the uplands and on T2 and T1 of Sacatosa Creek. These same components may also be found buried within the late Holocene undifferentiated veneer along Sacatosa Creek. Where isolated from the erosional episode between 3300 and 1750 B.P., Late Archaic sites may be found in Unit IV of Sacatosa Creek. Aggradation of Unit IV was slow and uniform, so that where left intact, site preservation should be favorable. Unit V of Sacatosa Creek may contain part of the buried Late Archaic record and most of the Late Prehistoric record. Historic sites may only be buried in Unit VI, or on the surface of TO overlying Unit VI along Sacatosa Creek. Unit VI may also bury sites dating primarily to the Late Prehistoric that are concentrated on the soil developed in the top of Unit V. Slow and uniform deposition of Units $\mathrm{V}$ and $\mathrm{VI}$ was also amenable to site preservation.

Because of age uncertainty, it has to be tentatively assumed that the Holocene undifferentiated unit in Trenches 1 and 2 of the uplands may contain cultural components from any period. 


\section{PALEONTOLOGY AND STRATIGRAPIIY}

\section{James O. Jones}

Most of Laughlin AFB is located on the Uvalde Gravel of Tertiary/Quaternary age (approximately one million years and less). Underlying the gravels, in descending order (Table 2-1), are the Cretaceousage Buda and Del Rio formations and the Salmon Peak Limestone (approximately 100 million years) (Barnes 1977).

Three major areas were investigated and all were found to have numerous marine fossils, both microand megafauna. A fourth area had been previously reported (Lasher 1989); however, upon detailed investigation it was determined that the fossils present at that site had been transported to the locality by human activity. Sites of significance were in the northwest area and the southeast area of the base proper and the area known as the Recreation Area and Marina. The western margin of the main base has very weathered Buda Limestone along the gravel roadway. If the area were excavated, fresh limestone would surely yield good specimens.

The possibility of plant and vertebrate remains being preserved in Pliocene/Pleistocene-age clay and gravel exists; however, none was observed. One large pebble, found in the Uvalde Gravel, contained a small fish with only the head missing. The enclosing rock appeared to be Buda Limestone, however, a definitive stratigraphic source was not obtainable. All available fossils were classified taxonomically based on Frizzell (1954) and Moore (1978) (Appendix B).

\section{NORTHWEST SITE- DEL RIO FORMATION}

Numerous fossils are present at the northwest site, predominantly Illymatogyra arietina (Figures 2-5 and 2-6). Fossil preservation at and near the surface of the Del Rio Formation is not good as many specimens are weathered almost beyond recognition. Excavation, however, would surely yield excellent specimens. The northwest site is mostly an outcrop of Del Rio Formation, however, the top of the hill is composed of Buda Formation. The Buda is highly weathered at this outcrop and usable fossils were not observed. Sixteen genera of megafossils, seven of foraminifers, and five of ostracods were observed in the Del Rio Formation (Appendix B, Tables B-1 and $B-2$ ). Abundant burrows and various sedimentary structures were observed. Samples of the microfossils were mounted on slides with numbered squares and are provided as part of this research. Numbers after the species refer to the numbered square on the slides.

Sedimentary structures and the fossil fauna indicate that the Del Rio Formation in this area was deposited in a very shallow marine bay or lagoon environment. Salinity of the water may have been slightly higher than normal as suggested by the presence of serpulid worms and the absence of corals. Oscillation ripplemarks are generated by bidirectional currents of approximately equal energy.

Table 2-1. Stratigraphic Column at Laughlin AFB

\begin{tabular}{||c|l|}
\hline Geologic Period & \multicolumn{1}{|c|}{ Formation } \\
\hline Quaternary/Tertiary & Uvalde Gravel \\
\hline \multirow{3}{*}{ Cretaceous } & Buda Formation \\
\cline { 2 - 3 } & Del Rio Formation \\
\cline { 2 - 2 } & Salmon Peak Limestone \\
\hline
\end{tabular}




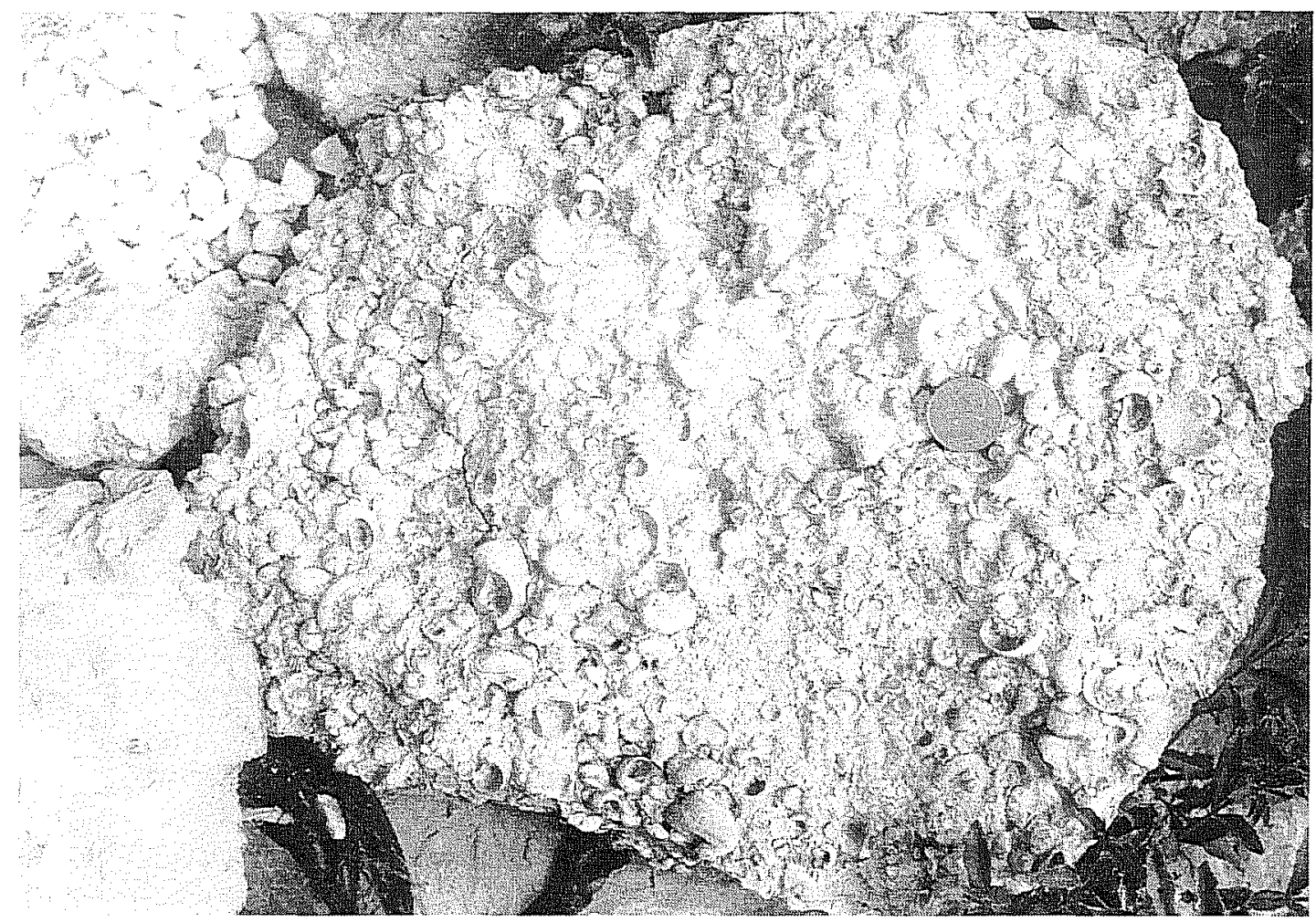

Figure 2-5. Slab of Illymatogyra arietina.

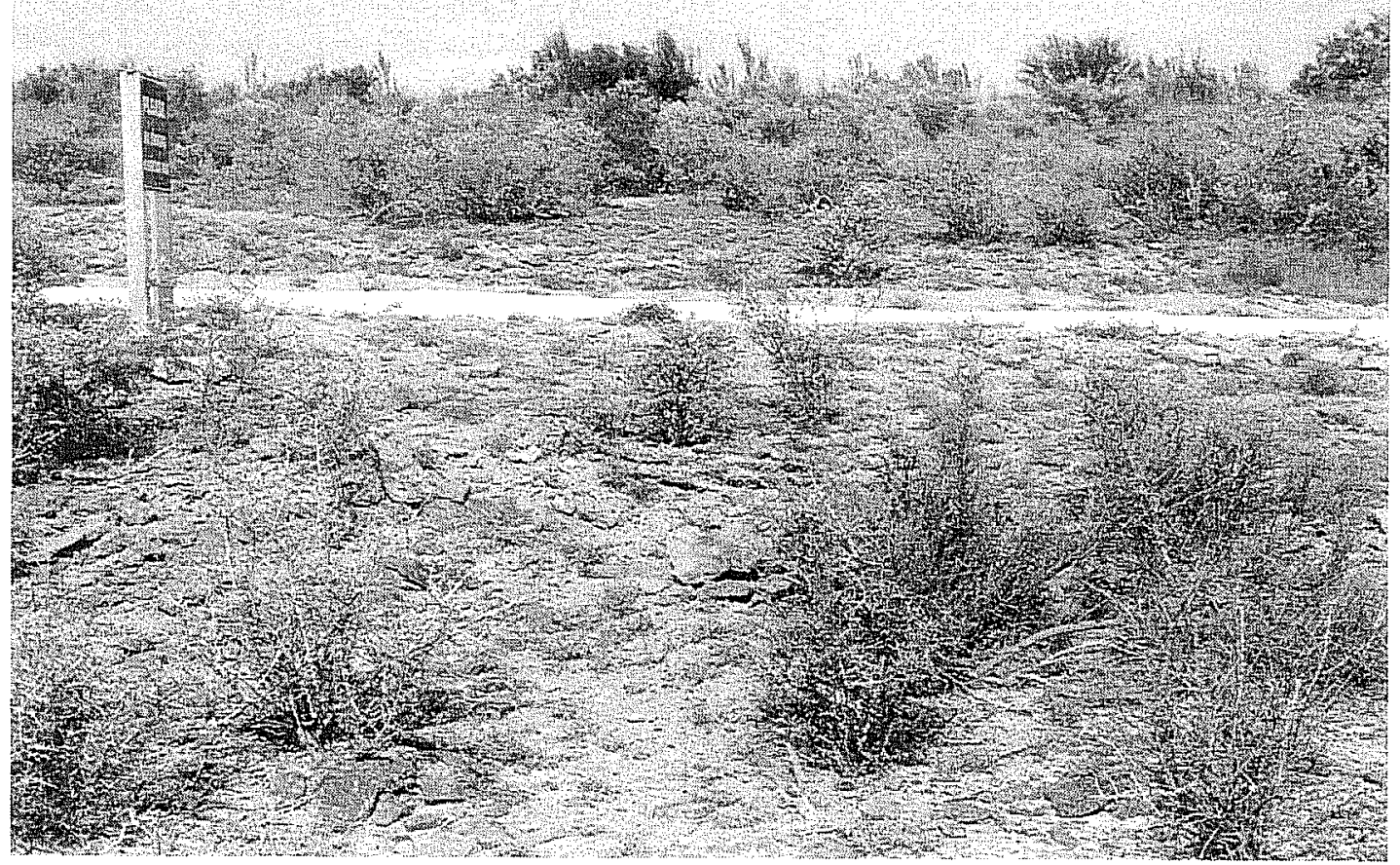

Figure 2-6. Outcrop of Del Rio Formation. 
The ripples here are small and were generated by low-energy currents, common in many bays and lagoons. Concentrations of Illymatogyra mixed with broken and unoriented shell remains of other fossils and the absence of most of the fine-grained sediment suggest that the sediment was removed and the fossil remains were moved and mixed during times of higher energy, such as storms.

\section{SOUTHEAST SITE- BUDA FORMATION}

The character of the Buda Limestone at the southeast site precludes the recovery of numerous specimens (Figure 2-7). Fortunately, some microfossils were recovered. Megafossils occur in the hard limestone and seldom weather out of the rock, instead they weather away with the rock. However, by breaking rocks with hammers and chisels, some megafossils were retrieved or exposed for identification. Quality of specimens varied from poor to good. Excavation through a construction process would surely provide excellent specimens. Nine genera of megafossils, six genera of foraminifers, and one ostracod genus were observed in the Buda Formation (Appendix B, Tables B-3 and B-4). Burrows were seldom observed, but were probably destroyed by lithification of the rock. Samples of the microfossils were mounted on slides with numbered squares and are provided as part of this research. Numbers after the species refer to the numbered square on the slides.

The fact that the basic rock is limestone indicates that the Buda Formation in this area was deposited in a very shallow, open marine environment. Salinity of the water was normal as indicated by the occurrence of corals (Parasmilia centralis?). Sedimentary structures are generally absent.

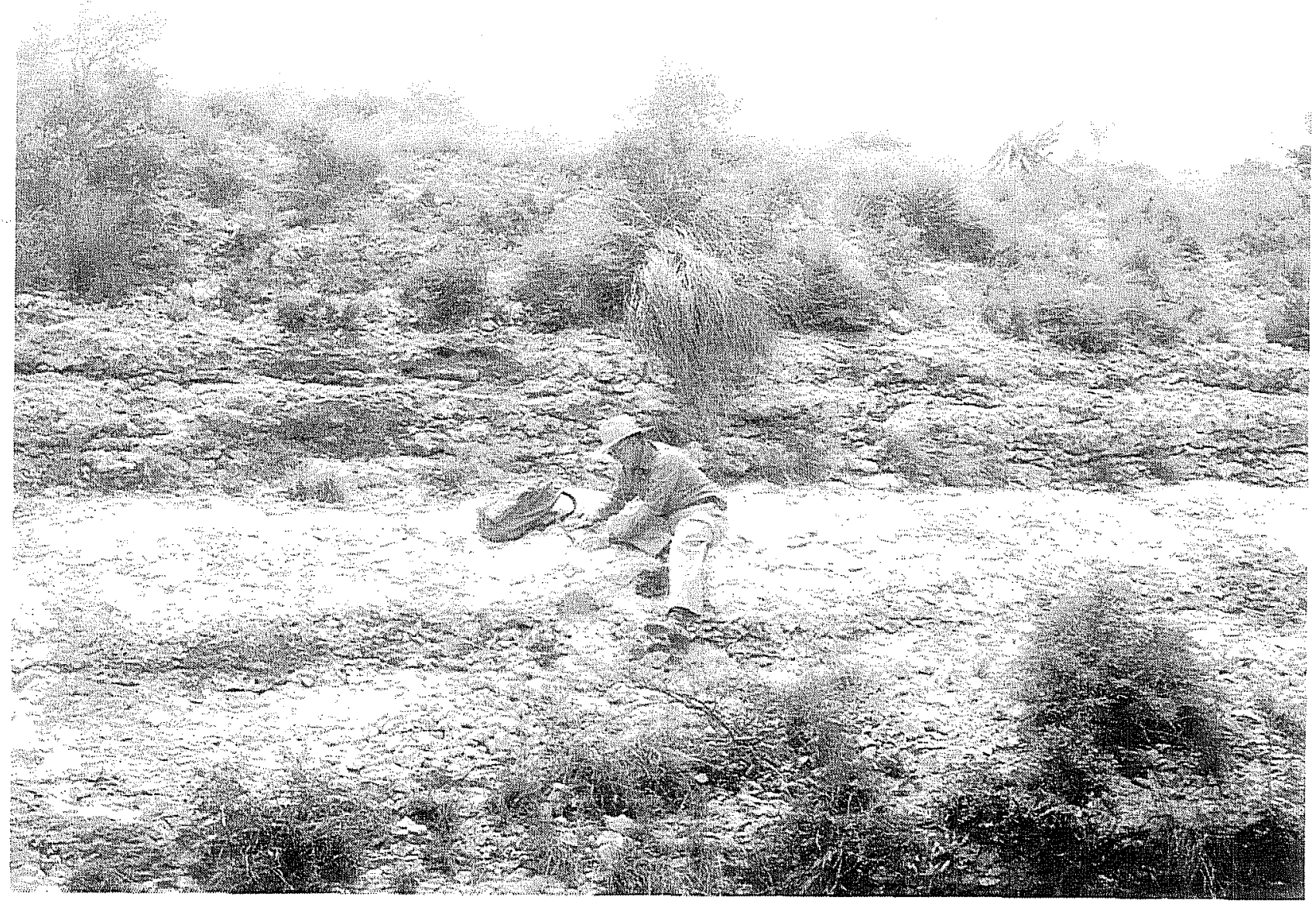

Figure 2-7. Outcrop of Buda Formation. 


\section{MARINA SITE- SALMON PEAK LIMESTONE}

Few fossils were observed at the marina site, mostly because of the encrusting calcium carbonate on surfaces normally covered by water and generally poor quality of exposures above normal pool level (Figures 2-8 and 2-9). Excavation of the Salmon Peak Limestone would surely provide good quality specimens. Five genera of megafossils and one microfossil genus were observed in the Salmon Peak Limestone (Appendix B, Table B-5). Probably the most notable is the caprinid type of clam and the ammonoid. The occurrence of limestone and normal marine fossils indicates that the Salmon Peak was deposited in normal marine conditions. Salmon Peak deposition was within the very large Maverick Basin surrounded by the Devils River Limestone-a reef with an opening to the south for normal water entrance.

\section{CONCLUSIONS}

Within the boundary of Laughlin AFB and the Marina are marine deposits containing abundant marine micro- and megafossil remains. Vertebrate and plant remains were not observed, but may be present in the soil and clay beds of the fluvial deposits.

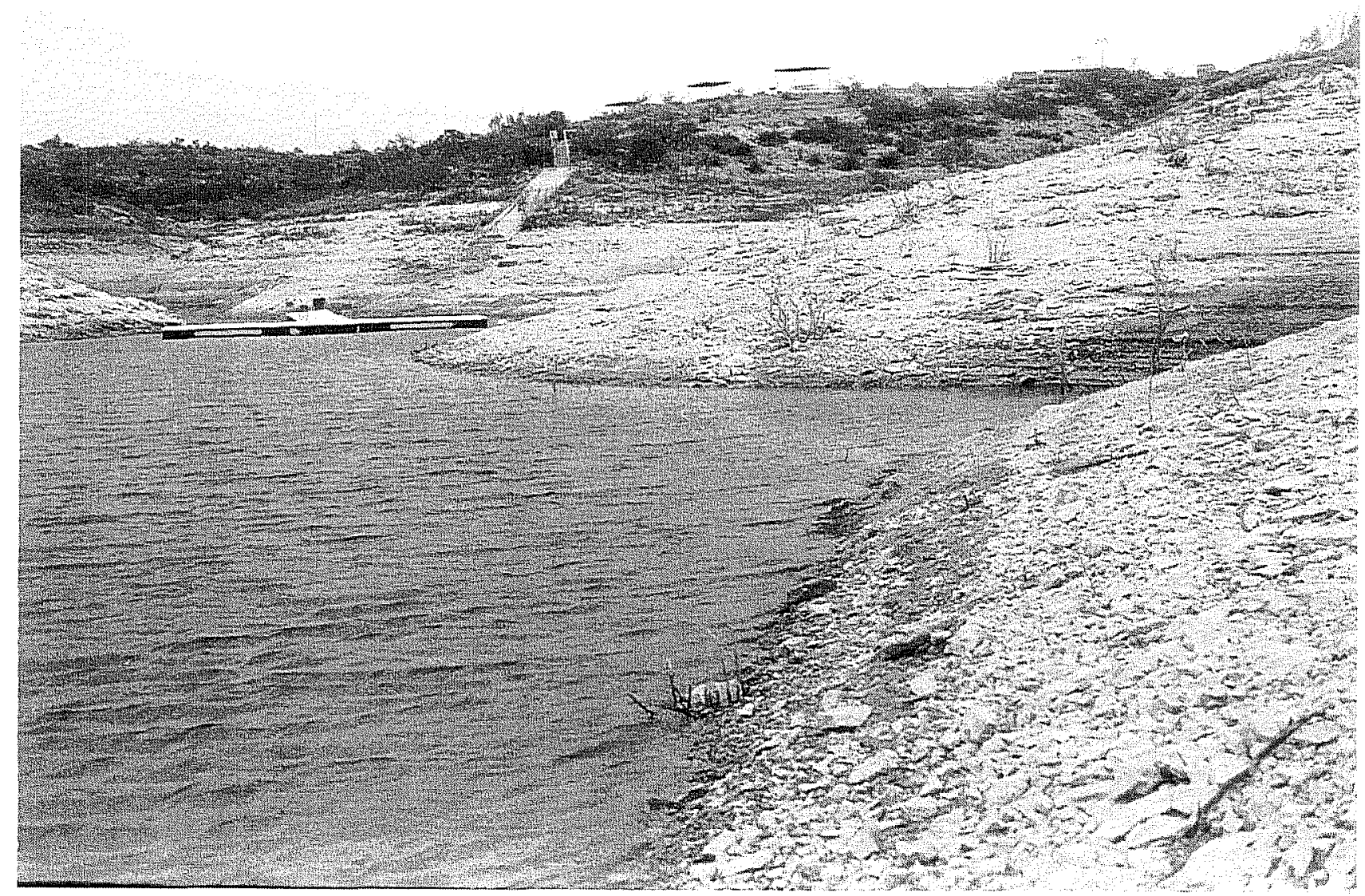

Figure 2-8. Outcrop of Salmon Peak Limestone at low water level. 


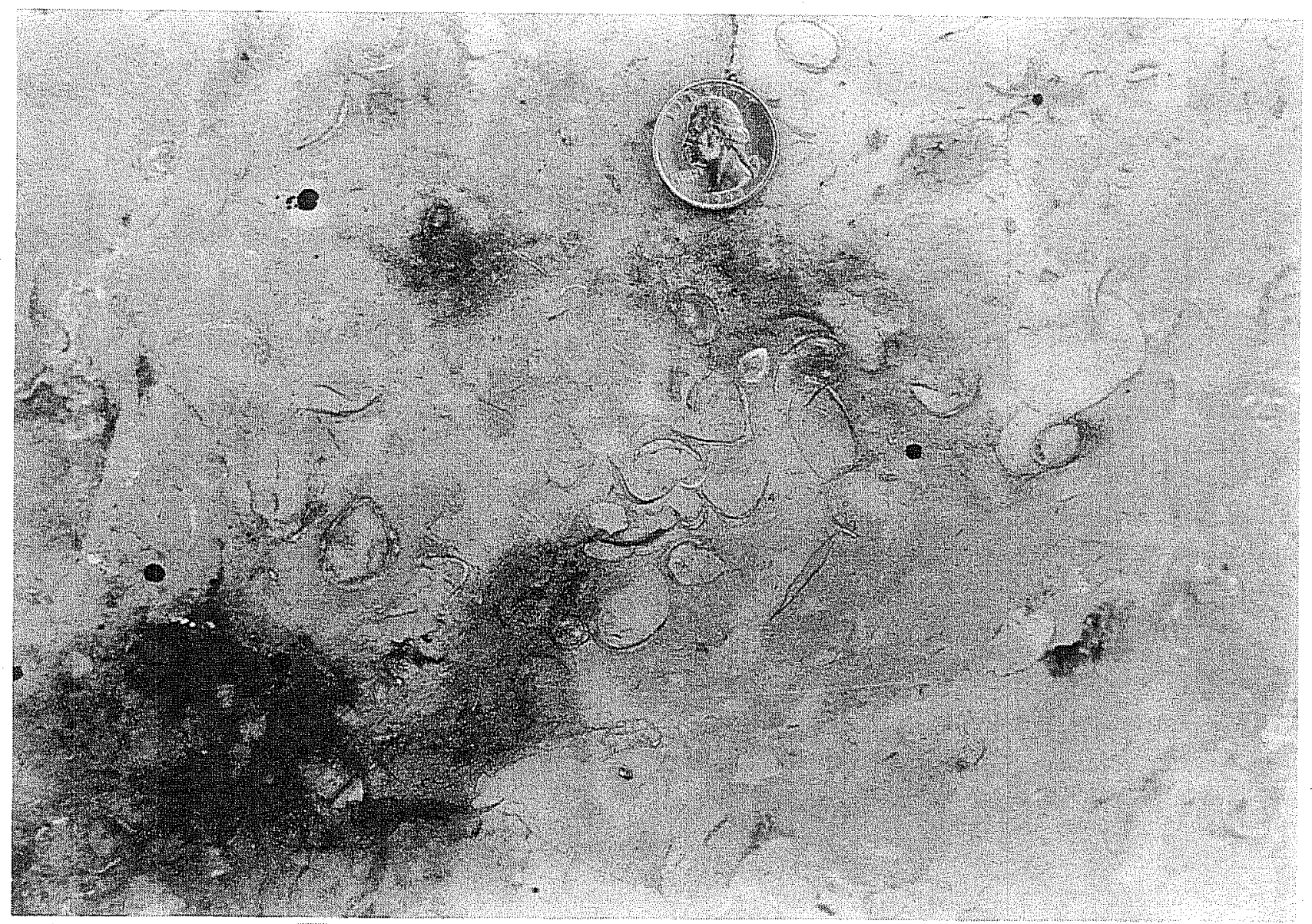

Figure 2-9. Salmon Peak Limestone above the low water level. Note the abundant rudistids and other clams. 


\section{Chapter 3. Methodology}

\section{Robert J. Hard, Marcie Renner, and Anna Jean Taylor}

This chapter details prefield and field investigations of the archaeological, historical, and natural resources of the Laughlin AFB project area. Laboratory procedures are also discussed.

\section{PREFIELDWORK INVESTIGATIONS}

Prefield investigations for the Laughlin project included: 1) conducting a preliminary literature and records search; 2) determining what archaeological and historical work had been conducted in the region; 3) identifying previously recorded archaeological and historical sites in the region; 4) providing field personnel with relevant data regarding the region; 5) formulating and organizing a plan to integrate the archaeological, historical, and geomorphological field work; and 6) preparing a manual for field and laboratory procedures. Some of this work was completed during the preparation of the proposal.

Research was conducted to determine what archaeological investigations were previously conducted in the region. Primary sources for this research included the files and library at the Texas Archeological Research Laboratory (TARL) at The University of Texas at Austin and those at CAR. Literature dealing with subjects such as the paleoenvironment and cultural chronology was also consulted. This information was used to determine the kinds of cultural and natural materials and features the project archaeologists could anticipate encountering in the project area. Examples of artifacts and materials known to occur in the region were presented to the field crew members and consultations were made with Joe Labadie, park archaeologist, National Park Service's Amistad National Recreational Area.

Research on the historic aspects of Laughlin AFB involved locating and reviewing relevant archival records on file at the base. Additionally, preexisting archaeological reports were examined for historical information, and an effort was made to locate relevant archaeological studies of historic American frontier sites. A literature and records search was conducted for data relating to protohistoric and historic Native American, Spanish, Mexican, and Euro-American populations in the region. Archaeological reports were used to gain information pertinent to historic site types; trails; settlement patterns; and land-use, particularly regarding water sources such as springs and creeks. Conversations with base personnel provided useful information and access to base records, especially valuable for tracing base modifications and the history of the property prior to its purchase by the military in 1942 . Personnel also provided leads regarding potential informants who would be knowledgeable about the history of the region. Information regarding the kinds of historic sites and artifacts expected in the project area was provided to the field personnel.

For the purpose of management of Laughlin AFB survey data, prefield preparations also involved the definition of sites anticipated to be present in the survey area. Based upon knowledge of the distribution and density of cultural material identified in other parts of the region, three categories of cultural properties were defined: large sites, small sites, and isolated finds (Table 3-1). Large sites have a density of 20 artifacts or greater within a $25-\mathrm{m}^{2}$ area, and/or are $100 \mathrm{~m}^{2}$ or larger in size, and/or contain two or more cultural features. Small sites have a density of 5 to 19 artifacts within a $25-\mathrm{m}^{2}$ area, and are less than $100 \mathrm{~m}^{2}$ in size, and/or contain a single cultural feature. Isolated finds have a density of less than 5 artifacts within a $25-\mathrm{m}^{2}$ area, are less than $100 \mathrm{~m}^{2}$ in size, and contain no cultural features. Exceptions could be made for areas which met the criteria for isolated finds but that yielded one or more unusual kinds of diagnostic artifacts, such as Paleoindian projectile points; such locations could instead be classified as sites. 
Table 3-1. Archaeological Site Definitions

\begin{tabular}{|c|c|c|c|}
\hline Site Type & $\begin{array}{c}\text { Artifact } \\
\text { Density } / 25 \mathbf{~ m}^{2}\end{array}$ & Area & $\begin{array}{c}\text { Features } \\
\text { Present }\end{array}$ \\
\hline Large & $20+$ & $>100 \mathrm{~m}^{2}$ & $2+$ \\
\hline Small & $5-19$ & $<100 \mathrm{~m}^{2}$ & 1 \\
\hline Isolate & $0-4$ & $<100 \mathrm{~m}^{2}$ & 0 \\
\hline
\end{tabular}

Prefield work also included subdivision of the project area into archaeological survey zones: 1) undeveloped uplands, 2) the recreation area and marina, 3) developed areas, and 4) the creek zone (Table 3-2). These zones were based upon vegetation, landform, and soils, detailed in Chapter 2, as well as expected cultural use of the landscape.

The upland zone consists of approximately 1,471 acres, or about 51 percent of the total project area. This area is comprised of hills and uplands located away from the creeks and has largely stable, intact, gravel surfaces with little soil or loess accumulation. The uplands are Cretaceous limestone and clays and Pliocene/Pleistocene Uvalde Gravel (Nordt, this volume). Raw lithic material, principally chert, is present in certain areas. The shrub vegetation in this zone mainly includes thorny plants, cacti, and grasses. Ground visibility ranges from 40 to 60 percent, but is generally better than 50 percent.

The developed zone consists of approximately 851 acres, or about 30 percent of the total project area. Vegetation is mainly comprised of yards with grasses and ornamental plants, resulting in ground visibility varying from 0 to 10 percent. The area is highly disturbed from grading and construction; reportedly, much fill dirt was brought into the developed zone, particularly at base housing, for landscape purposes (Ralph Mitchell, personal communication 1994).

Because identification of disturbed portions of the developed area was not apparent from field observations, CAR archaeologists interviewed base personnel to learn more about known archaeological sites in the developed areas, as well as other portions of the base. Locations of previously existing buildings were obtained from historic maps of the base, and individuals affiliated with the base engineering office were consulted to assist in the identification of disturbed areas and in determining the ages of certain structural remains located by CAR archaeologists within the developed area.

The creek zones along Zorro and Sacatosa creeks includes approximately 533 acres, or about 18 percent of the total project area. These areas contain bluffs, alluvial terraces, floodplains, and floodplain margins within $100 \mathrm{~m}$ of floodplains. This zone frequently contains dense thorny shrubs and grasses, with some patches of shrub vegetation which form impenetrable thickets. The ground visibility ranges

Table 3-2. Laughlin Air Force Base Archaeological Survey Zones

\begin{tabular}{|c|c|c|c|c|}
\hline Zone Type & $\begin{array}{c}\text { Area in } \\
\text { Acres }\end{array}$ & $\begin{array}{c}\text { Vegeta- } \\
\text { tion }\end{array}$ & Landform(s) & $\begin{array}{c}\text { Ground } \\
\text { Visibility }\end{array}$ \\
\hline upland & 1,471 & shrub & upland hills and flats & $40-60 \%$ \\
\hline creek & 533 & $\begin{array}{c}\text { dense } \\
\text { shrub }\end{array}$ & $\begin{array}{c}\text { floodplain, alluvial terraces, and } \\
\text { areas within 100 m of floodplain }\end{array}$ & $0-40 \%$ \\
\hline developed & 851 & yards and grass & disturbed & $0-10 \%$ \\
\hline $\begin{array}{c}\text { recreation \& } \\
\text { marina }\end{array}$ & 45 & shrub & terrace & $85-90 \%$ \\
\hline
\end{tabular}


from 0 to 40 percent and is directly related to the shrub density.

The Laughlin Recreation Area and Marina (Figure 3-1) zone consists of approximately 45 acres, or about two percent of the total project area. The landform within this zone is actually uplands. No canyons or arroyos incise this zone, although part of this area borders a steep canyon and overlooks Amistad Reservoir. The flora at the marina is generally a xeric scrub community consisting of prickly pear, sotol (Dasylirion texana), Spanish dagger (Yucca treculeana), blackbrush acacia, and mesquite trees (Prosopis glandulosa). Thus visibility is good, about 85-90 percent.

\section{ARCHAEOLOGICAL FIELD INVESTIGATIONS}

The major objective of the Laughlin project was a baseline, 100-percent pedestrian survey of the approximately 2,900 acres within the project area, which included much of Laughlin AFB and the Air Force Recreation Area and Marina. CAR archaeological survey crews were responsible for locating and recording prehistoric and historic cultural resources in a manner suitable for evaluation of site significance and potential nomination to the National Register of Historic Places. The archaeological survey was conducted by the CAR staff from April 12 through May 27, 1994.

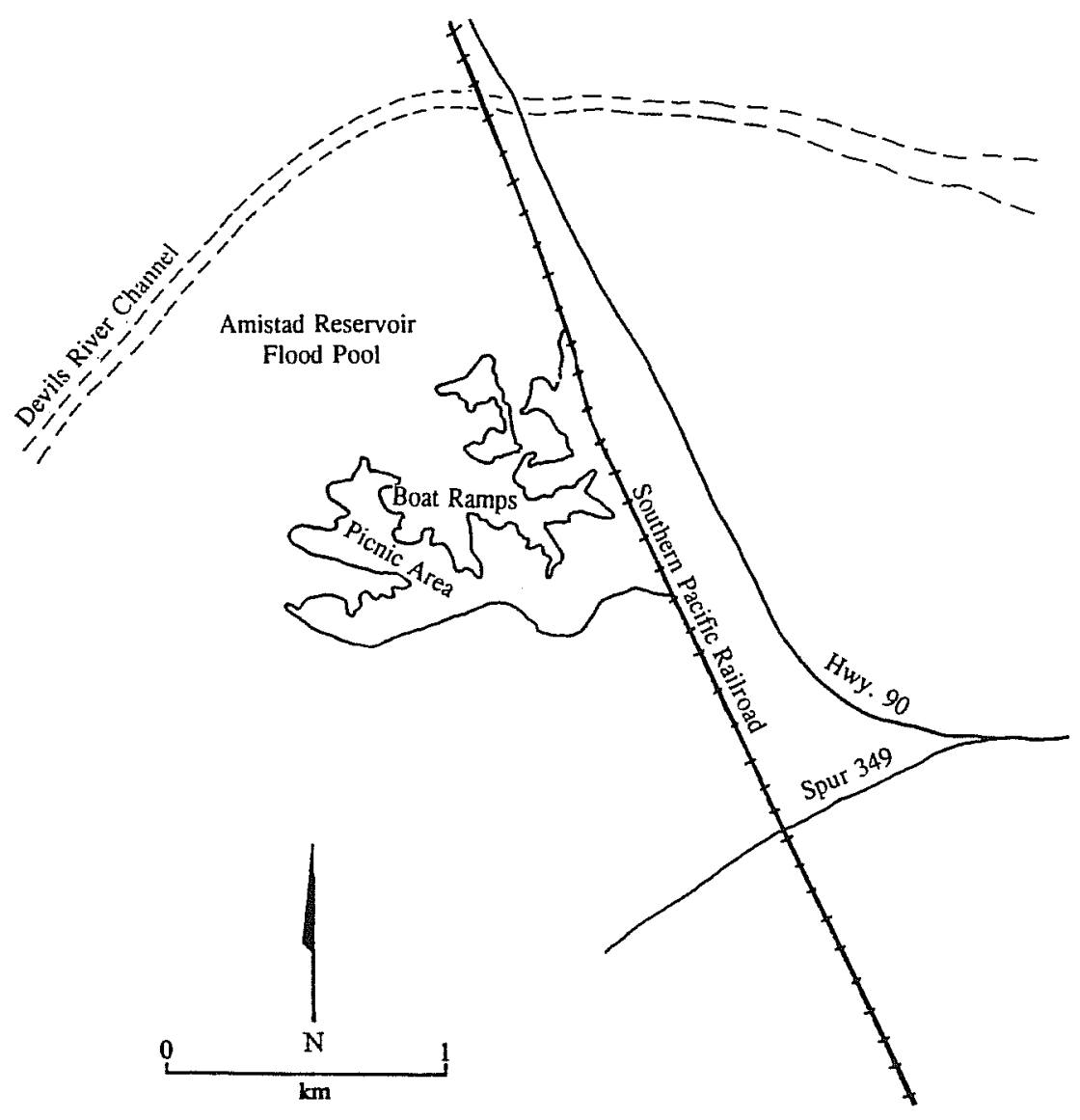

Figure 3-1. Map of the Air Force Recreational Area and Marina. 
In July 1993, prior to the initiation of the archaeological survey by CAR, Steven De Vore of the National Park Service conducted a cultural resource assessment of Laughlin AFB and the Air Force Recreation Area and Marina to assess the potential for archaeological sites. A limited pedestrian inspection of open areas resulted in the location of three archaeological sites, 41VV16531655, and one isolated find, 41VV1652 (De Vore 1993). Developed areas within the base proper were also investigated. Based on these observations, the potential for intact archaeological resources within the base boundary (excluding certain highly disturbed areas) was assessed to be high, and a baseline archaeological survey of Laughlin AFB was recommended by the National Park Service. The highly disturbed areas noted by De Vore (1993; NPS 1993: $\mathrm{C}-3$ and $\mathrm{C}-4$ ) and excluded from the recommended survey area, are the runway system, golf course, sewage disposal ponds, and two gravel pits (Figure 3-2).

\section{SURVEY METHODS}

The archaeological reconnaissance entailed a walkover of the project area by crew archaeologists supervised by the project archaeologist and/or a crew chief; also, the principal investigator periodically visited the project in the field. The survey was conducted by one to two crews of archaeologists ranging from three to six members each. All crew members were experienced in archaeological survey and site recording. For safety purposes, a portable radio unit was provided by the Laughlin AFB Security Police and was carried by a crew member during field investigations. Additionally, the CAR staff checked in daily with both the BHPO, Mr. Ralph Mitchell, and the Security Police so that base personnel were informed as to the archaeologists' location.

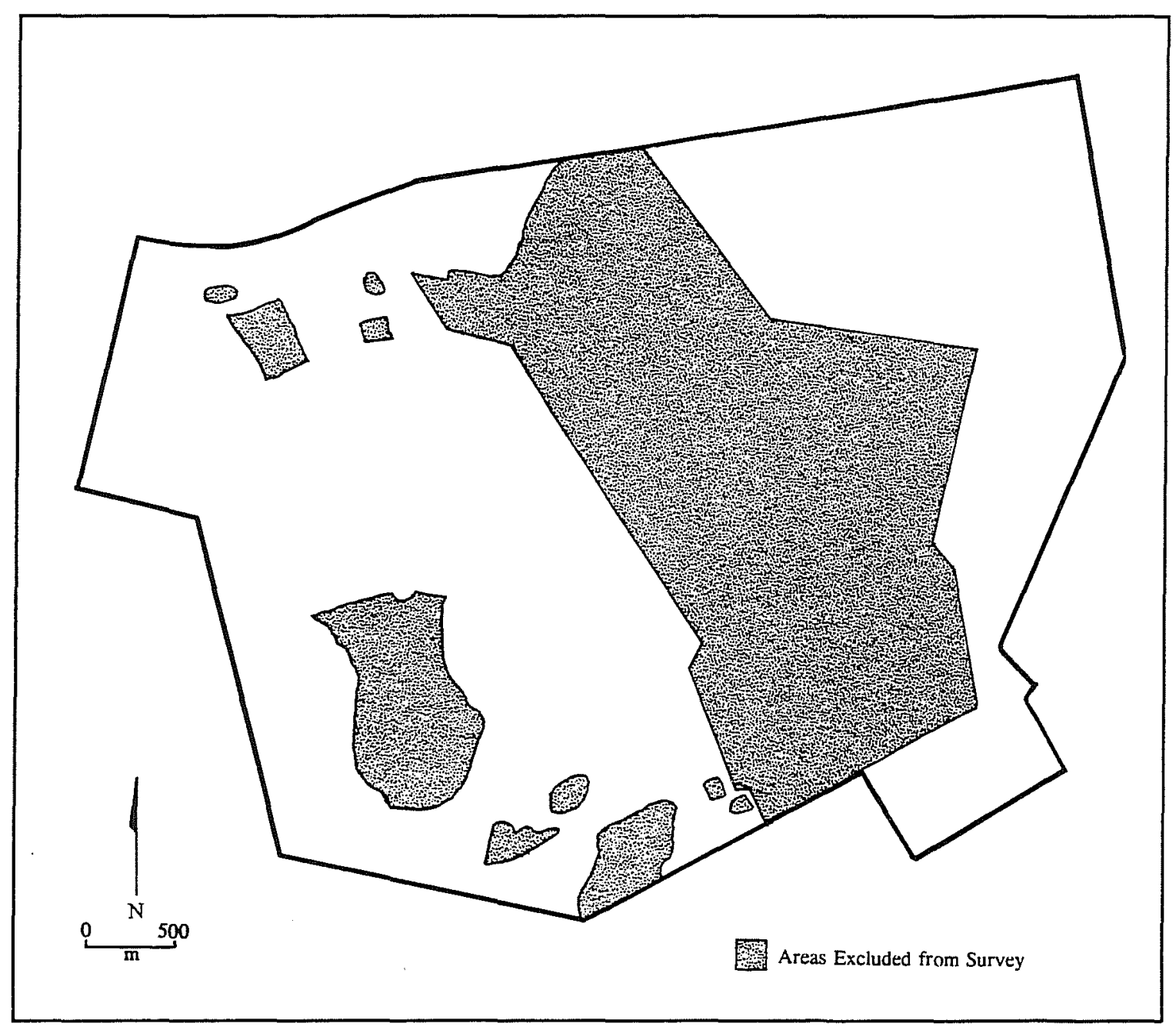

Figure 3-2. Map of Laughlin AFB with areas excluded from the survey indicated. 
During the survey, the ground surface was examined systematically using the transect spacing determined best for each defined zone.

1) Upland zone. The upland zone was surveyed by crew members in transects spaced $20 \mathrm{~m}$ apart. All cut banks, road cuts, and exposed slopes were inspected for archaeological deposits.

2) Creek zone. The creek zone was surveyed by crew members walking parallel to the drainages in transects spaced at $20-\mathrm{m}$ intervals except where prevented by dense vegetation. Eroded surfaces and cut banks were inspected for buried cultural material. Clusters of extremely dense vegetation which the field crew found to be impenetrable were circumvented. Although the patchy nature of the shrub thickets prevented consistent crew spacing, the average spacing of $20 \mathrm{~m}$ between crew members was judged to provide thorough coverage of this zone.

3) Developed zone. The developed portion of Laughlin AFB was surveyed, with special attention given to the housing, hospital, and stables areas where archaeological sites had been reported. Previously disturbed areas were identified through information reported by $\mathrm{De}$ Vore (1993), interviews with base personnel, and from early maps of Laughlin AFB. Given its generally disturbed condition and the low probability of locating intact sites, the developed zone of Laughlin AFB was judged to require a low-intensity survey. Accordingly, field crew members used a zig-zag pattern to cross-cut yards and walk around buildings, and other parts of the developed area. Ground surface exposure from erosion, road cuts, animal activity, etc. were carefully checked. In the housing areas crew members deliberately avoided entering fenced-in yards, choosing rather to have one member walk across the unenclosed front yard areas while a second member walked through the area behind the backyard fences; this procedure was chosen to avoid intruding on the privacy of the basehousing occupants.
4) Air Force Recreation Area and Marina. This upland zone was surveyed by crew members in transects spaced $20 \mathrm{~m}$ apart. Much of the shoreline of Lake Amistad was exposed below the usual water level at the time of the survey, making more of the area available for inspection.

The two survey crews usually worked independently within separate areas delineated by roads and identified as Sectors 1 through 14 (Figure 3-3). The sectors provided useful survey units which were covered in numerical order. Most transects originated at and ran perpendicular to a road. The crew members walked in a zig-zag pattern to maximize the amount of ground surface covered. Because very dense vegetation was present in some areas, the outermost surveyor marked the limits of his/her transect with flagging tape. The crew member(s) in the middle of a transect kept in visual or verbal contact with the crew members to their sides.

When cultural remains were first discovered, the area was investigated sufficiently to determine its status as a site or an isolated find. Isolated finds were recorded at the time they were located. For sites, the location was plotted on a $1 "=500^{\prime}$ base map and the site was marked with flagging. The crew continued the survey of that particular area or sector. Once the entire survey was largely completed, the crews returned to each of the sites for recording, testing, and possible artifact collection.

\section{RECORDING METHODS}

All sites were recorded using State of Texas Archeological Site Data forms. Isolated finds were recorded on separate forms prepared for this project. Appendix $C$ contains samples of forms used in all aspects of the project.

A temporary field designation, consisting of "Laughlin" followed by a sequential number (for example, "Laughlin 5") was assigned to each located site. Eighteen field site designations were assigned. Six localities initially assigned field site designations were later identified as being recent in age, another was a previously recorded site, and another proved to be part of a large site. Trinomial site designations were obtained from the Texas Archeological 


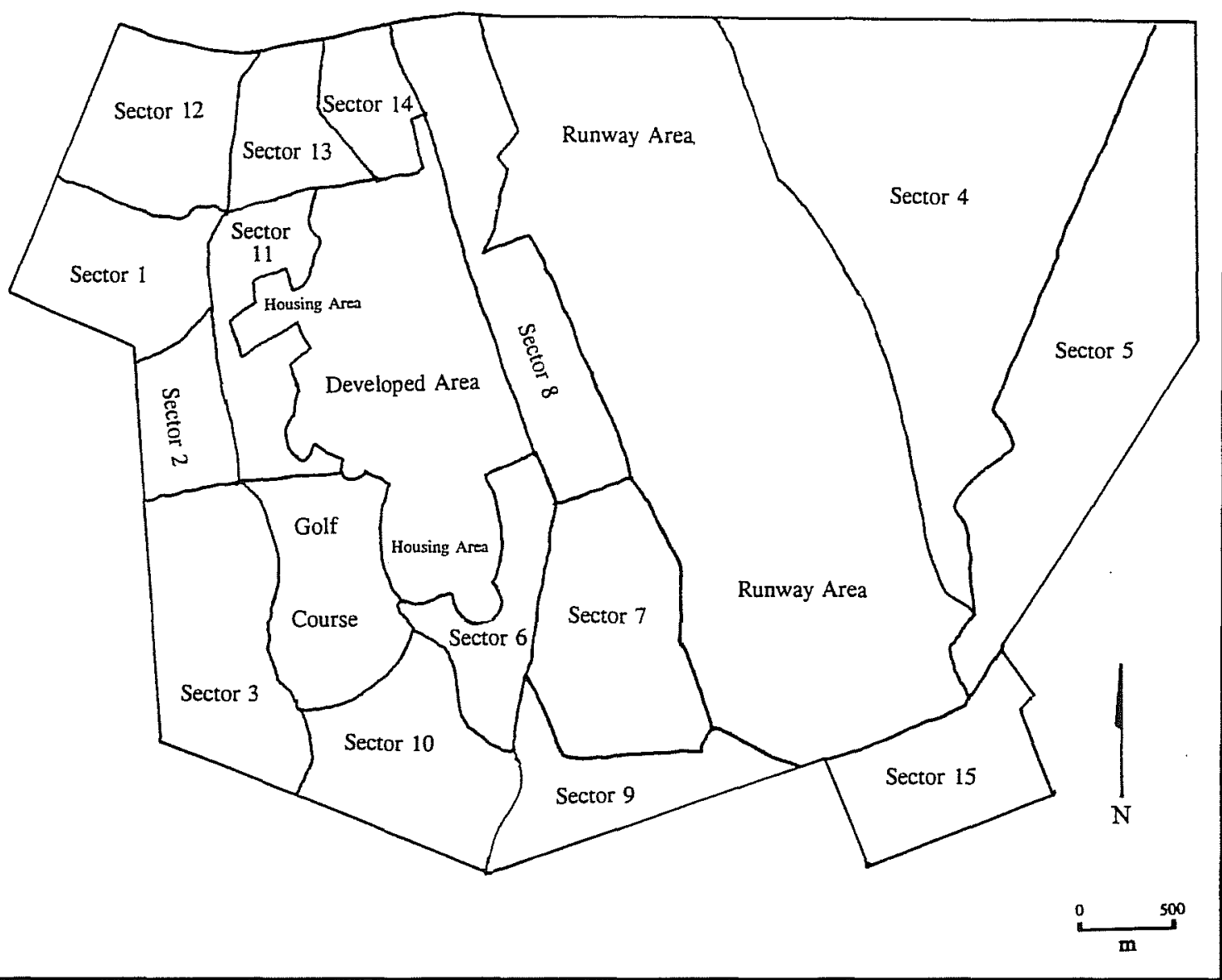

Figure 3-3. Map of Laughlin AFB showing sectors delineated for the survey.

Research Laboratory, The University of Texas at Austin, and were assigned to the 10 previously unrecorded sites located during this project. Twelve isolated finds, designated by the initials "IF" followed by a sequential number (for example, "IF 5"), were identified during the field survey.

Locations for sites and isolated finds were plotted on the $1^{\prime \prime}=500^{\prime}$ base map and also on the 7.5' USGS topographic quadrant Del Rio SE. Coordinates, consisting of latitude and longitude, were also obtained for the sites using a Sony hand-held global positioning system (GPS) unit, provided by Laughlin AFB personnel, which was accurate to within 30 to $100 \mathrm{~m}$.

Site boundaries were established by having crew members fan out radially from known artifact areas. Boundaries were generally established at the point where exposed cultural features and/or artifact densities fell off substantially. Site boundaries were indicated on the USGS 7.5' Del Rio quadrangle and the Laughlin AFB map ( $1^{\prime \prime}=500^{\prime}$ scale).

All recording for both prehistoric and historic resources was performed in metric units. A scaled compass-and-pace sketch map showing major modern, natural, and archaeological features; the site datum; shovel test units; collection areas; site boundaries; and disturbance areas was made for each site.

A permanent site datum consisting of a length of rebar was driven into the ground, leaving about 10 to $15 \mathrm{~cm}$ of the post extending above the surface, within each site. Attached to each datum with a copper wire was an aluminum tag on which was inscribed the following information: trinomial site designation, UTM coordinates, date established, and agency performing the work (CAR). 
Two cameras were used to document all sites with 35-mm black-and-white and color photographs. Site photographs included views of the general terrain, features, and shovel tests. Panoramic, non-sitespecific photographs were taken of the project area, and also of work in progress to document field methods. A photograph log was kept to inventory the photographic film and coverage.

\section{SHOVEL TESTING METHODS}

For the investigations conducted at Laughlin AFB, 88 shovel tests were performed. These were numbered sequentially and tracked in a shovel test log. All recovered cultural material was recorded and bagged. Any recovered special samples were noted on a special sample log.

Shovel tests were dug within each site to provide information about the nature and the horizontal and vertical distribution of the cultural deposits. The number of shovel tests dug within a particular site was decided on a case-by-case basis, with site size, density of cultural material, extent of subsurface sediments, landform, and vegetation all considered.

Shovel tests ranged from 30 to $35 \mathrm{~cm}$ in diameter and were hand excavated to a maximum depth of $50 \mathrm{~cm}$ below the modern ground surface. Sediments were removed in arbitrary $10-\mathrm{cm}$ levels and were screened using $1 / 4$-inch wire mesh. Cultural material recovered from shovel tests was bagged by level and retained for analysis. Information regarding sediment color and texture and recovered cultural material was recorded on a shovel test form developed for the project. Locations of shovel tests were recorded on the site maps. Shovel tests were backfilled after site recording was completed. Information regarding subsurface deposits within the project area was supplemented with the findings of Nordt's geomorphological investigations.

\section{COLLECTION METHODS}

The artifact collection strategy included surface collection of artifacts which were potentially temporally or functionally diagnostic; locations of diagnostic items were recorded on the site maps. All cultural material, with the exception of burned rock, was collected from shovel tests. These objects were bagged, assigned sequential artifact numbers, and when appropriate, drawn on the back of the field record form. A count of burned rock recovered from each $10-\mathrm{cm}$ level in the shovel tests was made and recorded on the shovel test forms. No apparently non-recent charcoal was located in the project area.

Chronologically diagnostic artifacts, referred to as unique items, received "Unique Item" designations consisting of the initials "UI" followed by a sequential number (for example "UI 15"). Information pertaining to unique items-including description, provenience, and a drawing-was recorded on a unique item log.

Counts of surface artifacts to be used for quantitative comparative purposes were made for each site using dogleash sample units (circular areas, $10 \mathrm{~m}$ in diameter). For all but the smallest sites at least two dogleash units were used; one unit was located in the area of apparently greatest surface artifact density, the other in an area of more moderate, or average, surface artifact density. The types and counts of artifacts observed within the sample units were recorded, and unit locations were plotted on the site maps.

\section{GEOMORPHOLOGICAL INVESTIGATIONS}

A geomorphological study was conducted by Lee Nordt of Texas A\&M University. Nordt's objectives were to determine where buried archaeological deposits and intact terrace surfaces might be present, and to evaluate the modification of the landscape by past cultural and natural processes. The geomorphological study included the excavation of 12 backhoe trenches to provide information for the assessment. Special attention was given to the deep alluvial terraces and colluvial deposits. Nordt's results are presented in Chapter 2 and Appendix A. 


\section{PALEONTOLOGICAL INVESTIGATIONS}

James O. Jones of UTSA performed a paleontological study of Laughlin AFB. Jones's goal was to classify known fossil formations on base and to identify any additional fossil bed exposures existing on the AFB proper or the marina annex. Jones located three areas-two on the base and one encompassing the marina-containing paleontological remains. The results of Jones's study are presented in Chapter 2 and Appendix B.

\section{HISTORICAL FIELD INVESTIGATIONS}

The historical field investigations included further examination of the base records and discussions with base personnel familiar with the history of the base. Records at the Val Verde County Courthouse, including deed records, were examined; these records revealed a chain of ownership of the property dating from the 1870 s until acquisition by the government in 1942. Other county records gave valuable information on sheep operations, prices, and land lease values. A visit to the Whitehead Memorial Museum in Del Rio included conversations with museum personnel regarding area history, and examination of the museum records.

Telephone interviews were conducted with Anselyn (Mrs. Gilbert G.) Marshall and Florence Marshall Major, both of Del Rio, Texas. Both women are members of the family which owned the property on which Laughlin AFB is now located.

\section{LABORATORY PROCEDURES}

Artifacts recovered during the Laughlin survey were transported to the CAR laboratory for processing and analysis. All artifacts were washed, air dried, sorted by type, and labeled with provenience. Catalogue sheets identifying artifact types and number of artifacts were filled out for each provenience. Artifact cataloguing and labeling includes the site number, horizontal and vertical provenience (if appropriate), and a sequential catalogue number (beginning with 1 for each site). Additional information in the catalogue includes date of recovery, last name of recoverer, quantity, material, and description.

Information from the catalogue sheets was entered onto a computerized spreadsheet for analysis. Selected fields of the artifact catalog are given in Appendix D. References to artifacts in this report include the site and sequential catalogue number or, in the case of IFs, LGH for Laughlin and the IF\#.

All recovered material culture, site records, and archival and administrative documents will be curated at the CAR laboratory. Site data packets, including maps, photographs, and State of Texas Site Data forms, were submitted to NPS for distribution to Laughlin AFB, the Texas Archeological Research Laboratory, and the Texas Historical Commission. A summary of the fieldwork (Hard et al. 1994) was also submitted to NPS for distribution. 


\title{
Chapter 4. Prehistoric Period Background
}

\author{
Cynthia L. Tennis
}

\section{HISTORY OF ARCHAEOLOGICAL INVESTIGATIONS}

Archaeologists have conducted numerous investigations in the Lower Pecos River region and have written and published much about the area. The extraordinary rock art and the well-preserved organic materials and artifacts in the caves and rockshelters dotting the canyon walls of the region have attracted attention since the 1930s. In the late 1950s and early 1960s, surveys and salvage archaeology activity increased in the area in conjunction with the construction of the Amistad Reservoir. In the 1970 s and 1980s, data from many previously excavated sites served as a basis for scholarly research which applied modern analytical techniques and processual questions to the area. This interest has continued into the present decade, producing numerous specialized studies as well as regional syntheses.

Archaeological work began in the Lower Pecos in the 1930s with the excavation of Fate Bell Shelter (Pearce and Jackson 1933). Throughout the 1930s and 1940s, excavations of Eagle Cave (Davenport 1936a, 1936b, 1937); Shumla Cave (Martin 1933); and Knight, Moorehead, and Goat caves (Setzler 1932, 1933) were carried out by representatives from the Smithsonian Institution, the Witte Museum, and The University of Texas at Austin. Detailed descriptions and large inventories of corded and woven artifacts were recorded from these shelters. From Fate Bell Shelter, for example, Pearce and Jackson (1933) recovered cordage, sandals, basketry, matting, burden bands, and belts made from woven sotol, agave, and grass fibers. These early investigations also yielded descriptions of burials (Setzler 1934) and pictographs (Kirkland 1937, 1938), as well as the first attempts at cultural chronology (Sayles 1935; Taylor 1948, 1949). Pearce and Jackson (1933) attempted to relate the fiber industries of the Lower Pecos to those from the Desert Culture of the Great Basin and the Basketmakers of the
Southwest. In each case, similarities were noted but the differences were viewed as great enough to rule out any direct relationships. Pearce and Jackson determined these cultures represented convergent adaptations to life in arid regions.

The imminent inundation and destruction of many canyon sites by the construction of the Amistad Dam and Reservoir in the early 1960s sparked much archaeological activity in the area. Story and Bryant (1966) compiled a series of environmental studies incorporating articles by Flyr (1966), Irving (1966), and Raun (1966) on the modern and ancient environments of the area. A survey by Dibble and Prewitt (1967) of the area to be impacted by the reservoir identified 68 additional sites in the area, including 4 buried sites, 13 rockshelters, and 51 open burned rock middens and/or lithic scatters. Collins (1969) excavated 10 Middle Archaic to Late Prehistoric sites in the area. Excavation began at Bonfire Shelter, a rare, stratified bison kill site (Dibble and Lorrain 1968), and at Eagle Cave (Ross 1965), Castle Canyon (Greer 1966), and Centipede and Damp caves (Epstein 1963). Open sites including Nopal Terrace (Sorrow 1967), Devil's Mouth (Johnson 1964; Sorrow 1968), and the Cammack site (Greer 1968) were also investigated. Rock art in the Pecos was reported by Grieder (1966) and Kirkland and Newcomb (1967), while Schuetz $(1956,1961,1963)$ published accounts of cultural material stored at the Witte Museum. Burials from sites in Mexico and the Lower Pecos were also described (Benfer and McKern 1968; Del Rio 1956; Greer and Benfer 1963).

The last 30 years has seen a continuation of interest in the Lower Pecos region, but the focus of the investigations has shifted from excavation and description to more specialized research designs. The geomorphology of the region was defined by Kochel (1982). Dibble (1975) continued his work at Bonfire Shelter in the lower beds of the kill site. Baker Cave was thoroughly excavated and the results analyzed (Chadderdon 1981, 1983; Hester 1983; Word and 
Douglas 1970). Hinds Cave was excavated by Shafer and Bryant (1977), and Maslowski (1978) described and analyzed the artifacts from Moorehead Cave. Survey and testing in the Devils River State Natural Area identified 239 new sites (Turpin and Davis 1990) and other surveys located several upland sites away from the canyon area (Labadie 1986; Peter et al. 1990; Prewitt and Dibble 1974). Seminole Sink, a vertical shaft burial tomb, was excavated (Marks et al. 1985), and skeletal analyses were done on burials from Shumla Cave (Glassman 1985) and Skyline Shelter (Powell 1991). Turpin (1991) and Turpin et al. (1986) described the changes in mortuary practices through time, while Steele and Olive (1989) made a comprehensive comparison of burial populations in the Lower Pecos and south and central Texas.

The paleoenvironment was investigated through pollen studies by Bryant and Shafer (1977) and Bryant and Holloway (1985). Subsistence of the prehistoric inhabitants of the area was reconstructed through numerous coprolite studies (Bryant 1974, 1986; Riskind 1970; Sobolik 1988, 1991; Stock 1983; Williams-Dean 1978) and Huebner's (1991) isotope studies, while Winkler (1982) looked at the availability and nutritional values of existing native plant foods. The role of meat in the diet was investigated through faunal remains by Dering and Shafer (1976), Douglas (1970), Lord (1984), and Lundelius (1984). Pictograph and petrograph styles continued to be analyzed for content and temporal differences by Mock (1987), Shafer (1975, 1977 , 1980), and Turpin (1984a, 1984b, 1986a, 1986b). Updated regional syntheses and chronologies have recently been proposed by Hester (1979, 1986), Shafer (1981, 1988), and Turpin (1982, 1991, 1995).

\section{CULTURAL CHRONOLOGY}

Reconstruction of prehistoric cultural phases within the chronological sequences of the Lower Pecos has been an area of some debate in recent years. Diagnostic point types tend to overlap, rendering dates based on association tentative. The major rockshelters, such as Baker Cave (Chadder- don 1983; Hester 1986), Hinds Cave (Lord 1984), and Fate Bell Shelter (Peck 1991), all show evidence of occupation throughout the Early, Middle, and Late Archaic periods, without clear indication of material culture changes. Until recently, the seven periods of the Amistad sequence established by Story and Bryant (1966) had been the standard used in most studies. However, continuing work and improved dating techniques have sparked new assessments. Most recently, Turpin $(1991,1995)$ has combined new and existing radiocarbon dates with the work done by Dibble (1975), Shafer (1986), and Story and Bryant (1966) to create the updated 12-phase sequence used here (Figure 4-1).

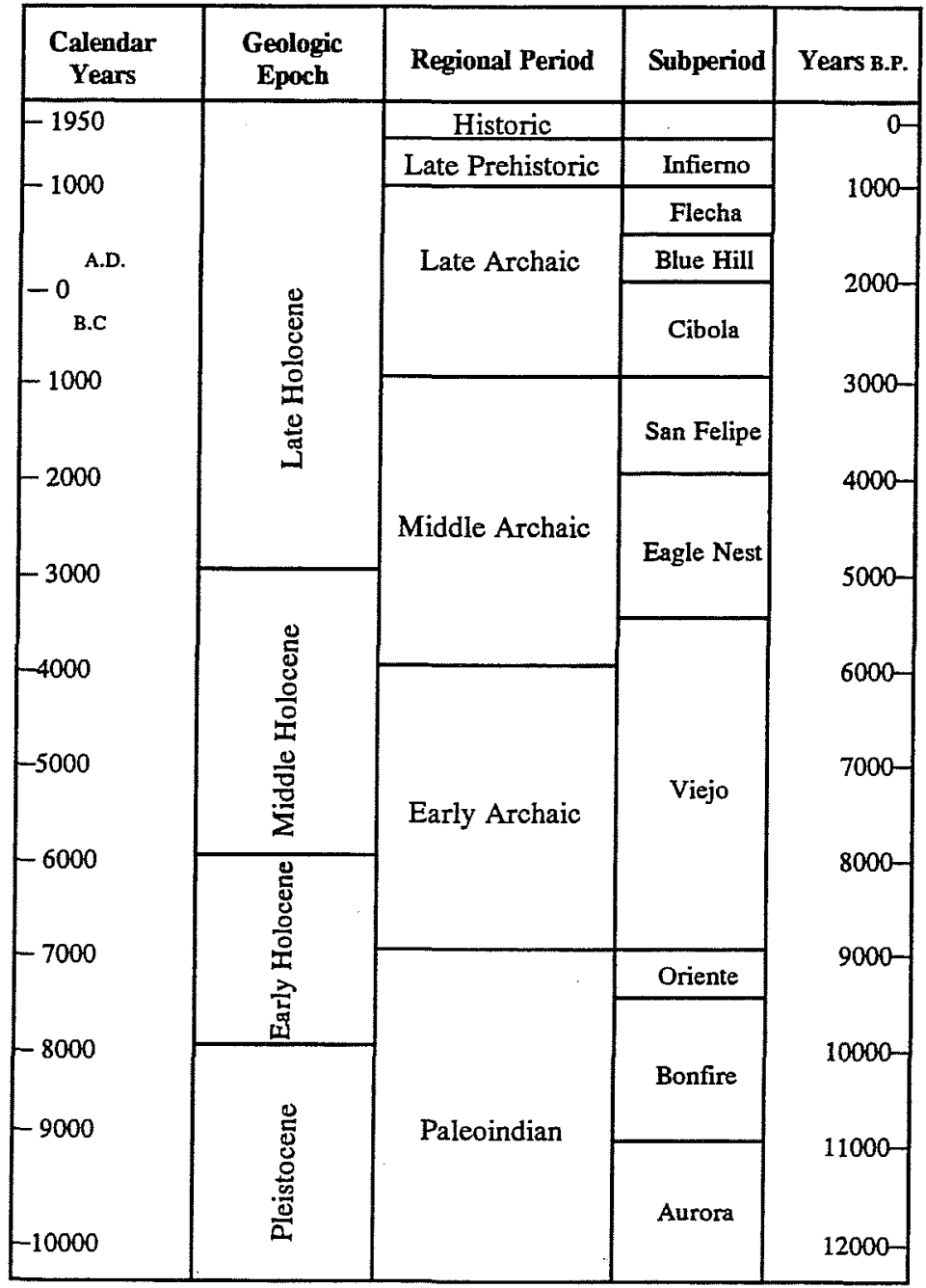

Figure 4-1. Regional chronology. 


\section{PALEOINDIAN PERIOD \\ $(14,500-8800$ в.P. $)$}

The Paleoindian period in the Pecos region is divided into three phases.

1) The Aurora phase $(14,500-11,900$ B.P.) is based on radiocarbon dates from charcoal found in association with extinct vertebrate remains in Bone Bed 1 in Bonfire Shelter (Dibble 1975). Although no formal tools were recovered from the lowest level of Bonfire Shelter, charcoal associated with extinct bison, camel, horse, and mammoth bones suggests human involvement. Heavily burned faunal remains with butchering marks from Cueva Quebrada, a small rockshelter adjacent to Conejo Shelter, also produced dates from this phase (Lundelius 1984). These bone beds support the model of big game hunters as the earliest occupants of the area.

2) The Bonfire phase $(10,700-9800$ B.P.) is based on radiocarbon dates from Bone Bed 2 at Bonfire Shelter. This level contained Folsom and Plainview projectile points in association with skeletal remains of an estimated 197 adult and juvenile bison (Bison antiquus). Investigations showed that the bison from this level had been almost completely butchered on the site, with the tops of many skulls removed from the site (Dibble and Lorrain 1968). This was a mesic period of general warming and gradual expansion of grasslands to support the megafauna in the region (Bryant and Holloway 1985).

3) The Oriente phase ( $9400-8800$ B.P.) is defined by the presence of Golondrina points at sites including Baker Cave (Hester 1983) and Devil's Mouth (Johnson 1964). The associated strata at these sites show evidence of full development of the various fiber-related artifacts for which the later periods are known. Analysis of the soil matrix from a cooking pit at Baker Cave which dated to this period showed evidence of black walnut, prickly pear, mesquite, rabbit, squirrel, rodent, and fish (Hester 1983), signs that adaptations to the changing climate were beginning by the end of the Paleoindian period. This period marks the end of the mesic environment and the beginning of the drying trend that persisted for the next 5,000 years (Bryant and Holloway 1985).

\section{EARLY ARCHAIC PERIOD (8900-5500 B.P.)}

The Early Archaic period consists of only one phase which lasted for 3,900 years:

1) The Viejo phase is characterized by Early Barbed, Early Stemmed, and Corner Notched projectile points (Turpin 1991). Eagle Cave, Hinds Cave, Baker Cave, Skyline Shelter, and Devil's Mouth have all produced radiocarbon dates that fall within this time frame (Turpin 1991). Floral and faunal analyses from Baker Cave (Chadderdon 1983) and Hinds Cave (Lord 1984) show the presence of walnuts, prickly pear, persimmon, hackberry, and mesquite along with deer, rabbit, rodent, and fish. Coprolite studies from Hinds Cave (Williams-Dean 1978) support this continuing shift in subsistence practices away from big game toward adaptations to the increasingly arid conditions described by Bryant and Holloway (1985).

\section{MIDDLE ARCHAIC PERIOD (5500-3200 B.P.)}

The two phases within the Middle Archaic are characterized by further adaptation to what Bryant and Holloway (1985) have identified as warm and dry periods marked by massive erosional episodes.

1) The Eagle Nest phase ( $5500-4100$ B.P.) is identified by the presence of a regional point type, the beveled Pandale, in association with radiocarbon dates within this span. Turpin (1991) suggests that the increasing regionalization of point styles during a time of near-drought conditions may indicate a hunting and gathering range restricted to the more isolated river sites.

2) The San Felipe phase ( $4100-3200$ B.P.) sees the trend to regionalization of projectile points continuing, with Langtry, Val Verde, and Almagre points. At Baker Cave, lecheguilla fruit appears (Chadderdon 1983) and fish and aquatic turtle supplement the faunal remains at Hinds Cave (Lord 1984). Based on an increase in 
projectile point frequencies at many of the larger rockshelters during this time, Turpin (1991) suggests a concentration of population along the rivers, perhaps prompting the need for ritual activity associated with the Pecos River style rock art that appears about this time.

\section{LATE ARCHAIC PERIOD (3150-1300 B.P.)}

The Late Archaic is divided into three phases, each marked by environmental, subsistence, and material culture changes:

1) The Cibola phase (3150-2300 B.P.) is described by Bryant and Holloway (1985) as a cooler, wetter interval. The trend toward regionality is evidently reversed as Marshall, Castroville, Ensor, Frio, and Montell points, usually associated with Central Texas (Turner and Hester 1993), appear in association with bison bones at Bonfire Shelter (Dibble 1975; Dibble and Lorrain 1968), Eagle Cave (Ross 1965), and Castle Canyon (Greer 1966). Prewitt (1970), Dibble (1975), and Turpin (1991) suggest that this change in point styles represents an intrusion by Plains hunters following the bison returning during this brief mesic interlude. However, at deeply stratified sites with Cibolaphase material, such as Baker Cave (Chadderdon 1983), Hinds Cave (Lord 1984), and Conejo Shelter (Bryant 1974), bison bone is not found and coprolite studies reveal a continued reliance on dry climate succulents and small mammals (Bryant 1974; Sobolik 1991). This suggests that the proposed influx of bison during this time did not dramatically alter the established subsistence patterns. Turpin (1984c) associates the Red Linear Style rock art to this period.

2) The Flanders phase (ca. 2300 B.P.) is marked by the appearance of the Shumla point. Radiocarbon dates associated with this point type are inconclusive, but the presence of Shumla points in Cueva de la Zona in Mexico has prompted Turpin (1991) to suggest an expansion into the area by inhabitants from Northern Mexico, filling a void created by the withdrawal of the bison hunters at the return of a more arid climate.
3) The Blue Hill phase (2300-1300 B.P.) overlaps with the preceding Flanders phase in dates as well as point types. Ensor, Frio, and Marcos points are found in the same layers as the Shumla points at Baker Cave (Chadderdon 1983), Hinds Cave (Lord 1984), and Bonfire Shelter (Dibble 1975). A shift in mortuary practices is seen by the appearance of bundle burials in dry rockshelters during this time (Turpin et al. 1986). Coprolite studies from this time period from Conejo Shelter (Bryant 1974) and Baker Cave (Sobolik 1991) indicate that sotol and yucca were of major importance in the diet while the faunal analysis from Baker Cave (Douglas 1970) indicates the continued importance of riverine species in the diet.

\section{LATE PREHISTORIC PERIOD (1320-250 B.P.)}

Both phases of the Late Prehistoric are marked by the introduction of the bow and arrow, distinctive tool kits, and other cultural changes.

1) The Flecha phase (1320-450 B.P.) is characterized by the appearance of the bow, along with small stemmed and unstemmed arrow points, at Cueva de la Zona (McClurkan 1980), Centipede Cave (Epstein 1963), and the Cammack site (Greer 1968). Turpin $(1991,1995)$ suggests that Red Monochrome rock art appears during this time. Burned rock rings and crescent middens in the uplands have also been associated with this time (Dibble and Prewitt 1967; Greer 1968). The crescent-shaped burned rock midden at the Cammack site revealed particles of burned sotol and lecheguilla still in place. Coprolites from Baker Cave (Sobolik 1988) and Conejo Shelter (Bryant 1974) show the continued importance of desert succulents to the diet of the peoples of this time period.

2) The Infierno phase (450-250 B.P.) is distinctive for its tool kit of small, stemmed arrow points. On the high promontories near reliable water sources, stone wickiup rings with evidence of pole supports, hearths, and ring middens have been recorded (Turpin and Bement 1988; Young 1981, 1982). Undecorated brown ceramic pieces, in limited quantities, have been recovered from the Cammack site (Greer 1968) 
and the upper strata of the Devil's Mouth site (Johnson 1964). Bold Line Geometric rock art also appears during this time (Turpin 1986b).

\section{PREHISTORIC CULTURAL OVERVIEW}

\section{SUBSISTENCE}

The earliest evidence of human occupation in the Lower Pecos Region surrounding Laughlin AFB reflects the highly mobile "big game hunter" adaptation associated with the Clovis and Folsom cultures across all North America (Hester 1989a, 1989b; Shafer 1986). Between 8000-9000 B.P., however, the climate in Texas became warmer and drier and the big game became less plentiful. People in the Lower Pecos region began to explore new adaptive strategies which centered on the exploitation of small game and available natural plant resources present in the region. The flexibility and mobility of this hunting and gathering way of life enabled the people to successfully adapt, without major change, to the continuing drying trend that occurred over the next 9,000 years.

The arid conditions and the choice of sheltered caves as living areas combined to leave deeply stratified, well-preserved records of life in the Lower Pecos throughout the Early, Middle, and Late Archaic periods. Floral and faunal analysis from Baker Cave (Chadderdon 1983; Douglas 1970; Hester 1986), Hinds Cave (Lord 1984), Cueva Quebrada (Lundelius 1984), and Fate Bell Shelter (Peck 1991) reveal that, except for variations in frequencies and the increasing reliance on desert succulents, the diet in the Lower Pecos remained essentially the same over time. Texas black walnut, prickly pear, persimmon, hackberry, buckeye, grapes, and mesquite and mescal beans were recovered from the Early Archaic occupations at Baker Cave (Chadderdon 1983; Hester 1986). During the Middle Archaic, lecheguilla appears. Sotol is added to the collection in the Late Archaic as black walnut disappears, reflecting the increased importance of desert plants as the climate became more arid. Faunal analyses from Baker Cave (Douglas 1970) and Hinds Cave (Lord 1984) reflect a similar consistency in the meat resources through time. While a wide range of terrestrial and aquatic game was exploited, deer from the uplands remained the primary source of meat in the diet, supplemented by rabbit and rodent in the Early Archaic, and by rabbit, fish, and aquatic turtle during the Middle and Late Archaic.

Latrine deposits have also been an important source of dietary information in the Lower Pecos. While coprolites are limited because they contain evidence from only 1-4 meals, enough samples from different time periods have been collected and analyzed to give an overall view of individual diets from 8500 to 2500 B.P. (Bryant 1974; Sobolik 1988, 1991; Stock 1983; Williams-Dean 1978). Sobolik (1988, 1991) compared these studies and found a consistent pattern that supports continued shift toward reliance on desert succulents. In Middle Archaic period samples, prickly pear, sotol, agave, and yucca appear to be staples in the diet. The fragmented nature of the prickly pear seeds in the samples suggest these staples were milled or ground before ingestion. Seeds from other plants-including juniper, mesquite, goosefoot, pincushion cactus, mustard plants, hackberry, acorn, and walnut-are also present, but in quantities suggesting a supplemental role during this time. Sobolik $(1988,1991)$ sees the consistent presence of sage brush and grass seed pollen as indicating these items were also stable, unchanged aspects of the diet. Stock (1983) and Williams-Dean (1978), however, interpret the presence as accidental additions from ingestion of rodents and birds (Sobolik 1988).

While protein-rich meat is not well represented in coprolites because of more complete digestion, some faunal dietary ingredients are detectable through the presence of small bones, fur, and fish scales. The samples from Hinds Cave (Stock 1983; WilliamsDean 1978), Conejo Shelter and Frightful Cave (Bryant 1974), and Baker Cave (Sobolik 1988, 1991) all contain evidence of fish, rodents, birds, and a low frequency of snake and lizard. Birds and rodents seem to have been eaten whole. Fish remains are associated with charcoal, an indication of roasting (Sobolik 1988). Huebner (1991) looked at total diet through a stable isotope analysis of five Late Archaic burials. Using human bone from four burials at Conejo Shelter and one burial at Skyline Shelter, Huebner identified a dietary pattern based on the combined use of CAM plants (desert succulents) and C3 (grazing) animals. He estimates 45-68 percent of the diet from the sample area came from CAM plants. 


\section{SEASONALITY}

Attempts have been made to understand the seasonal rounds of the hunting and gathering prehistoric peoples of the Lower Pecos region through the study of pollen remaining in the prehistoric soils and coprolites. Alexander (1970), in his pollen study from Parida Cave, found high proportions of lecheguilla, prickly pear, and sotol. Based on the fact that these plants are available on a year-round basis in the area, he raised the possibility that Parida may have been the site of long-term occupations, possibly serving as a permanent campsite from which longrange foraging was conducted. From Conejo Shelter samples, Alexander (1974) found a consistent mix of pollens; based on seasons of ripening, he determined the pollen represented long, seasonal occupations from early summer to late fall.

Bryant (1974), Riskind (1970), Sobolik (1991), and Williams-Dean (1978) used pollen residue in coprolite samples from their study areas to assign probable seasons of use to these sites. Occupations of middle to late summer have been suggested for Parida Cave (Riskind 1970), spring to early summer for Conejo Shelter, and spring to early fall for Frightful Cave (Bryant 1974). Pollen present in Hinds Cave samples suggests summer occupations (Williams-Dean 1978), and late summer to fall is suggested at Baker Cave (Sobolik 1991).

In their study of matrix samples from Gobbler Shelter, Dering and Shafer (1976) found leaf and caudex fragments of yucca, lecheguilla, and sotol. They also found fruits from mesquite, juniper, prickly pear, oak, walnut, and persimmon. While these findings support the existing information on subsistence in the area, Dering and Shafer found it impossible to assign seasonality using this information. Instead, after reviewing several accounts of varying blooming periods of these plants in modern times, they found that blooming times are highly variable, based more on a combination of temperature and precipitation than on the change of season. Plants have been shown to bloom after a rain, no matter the season, and many times plants will bloom and fruit more than once a year under the right climatic conditions. Therefore, Dering and Shafer raise doubts about the use of pollen in determining seasonality in arid locations.
ROCK ART

The rockshelters that dot the walls of the major river canyons in the lower Pecos region are known for their wide array of pictographs and petroglyphs. Through work done by Kirkland and Newcomb (1967), Shafer (1977, 1986), Turpin (1984b, 1984c, 1986a, 1986b, 1991, 1995), Turpin and Bement (1985), and others, four prehistoric and one historic style of pictographs have been defined. The earliest, the Pecos River style, contains lifesize and larger humanoid and animalistic figures in red, black, yellow, white, and green. This style probably dates to the Middle Archaic period, 3200-3900 B.P. (Turpin and Bement 1985). Red Linear, characterized by red, miniature human stick figures and fullbodied deer and bison, has been dated to the Late Archaic period between 3150 and 1300 B.P. (Turpin 1984c, 1995). Both the Red Monochrome with its full bodied, naturalistic depictions of humans and animals, and the red and yellow abstract designs of the Bold Line Geometric style are though to have occurred during the Late Prehistoric, 1320-450 в.P. (Turpin 1984b, 1986a, 1986b, 1995). 


\title{
Chapter 5. Prehistoric Sites and Isolated Finds
}

\author{
Barbara A. Meissner, Anna Jean Taylor, Cynthia L. Tennis, \\ and Kevin J. Gross
}

\section{RESULTS}

Thirteen archaeological sites were recorded on Laughlin AFB, three by De Vore (1993) and 10 during this phase of investigation. Of these 13 sites, 11 (41VV1653, 41VV1655, and 41VV1683-1691) were composed of prehistoric components. Diagnostic projectile points representing Late Paleoindian through Late Prehistoric occupations were recovered from five of these sites. One historic site (41VV1682) consists of remnants of the headquarters of the Zacatosa Ranch which occupied the immediate area from the 1920s to the 1940s when the property was bought for use by the military. One site (41VV1654), recorded by De Vore (1993), has a large prehistoric component-Late Paleoindian to Early Archaic-as well as a historic component associated with the Zacatosa Ranch and an earlier, possibly pre-1900, artifact scatter. Artifact types and densities were recorded and shovel tests were excavated at each of the 13 sites.

Thirteen isolated finds were also recorded, 10 consisting of prehistoric cultural material, one (41VV1652) with prehistoric and historic material (De Vore 1993), and two with historic material. Site 41VV427, previously recorded at the Air Force Recreation Area and Marina, was not relocated during this present survey.

\section{PREHISTORIC SITES}

Descriptions for each of the 12 prehistoric archaeological sites located within the project area are provided in the following section. Included are details regarding the natural setting at each site including the topography, soils, and vegetation. Further site-specific descriptive information is provided concerning cultural features, dogleash-unit inventories, subsurface testing, and artifacts.
$41 \mathrm{VV} 1653$

Site 41VV1653 (Figure 5-1) is a prehistoric lithic scatter first recorded by De Vore (1993) during a preliminary survey of the base and reinvestigated by CAR staff during the current project. The site is on the western side of the base, in an area set aside as a nature preserve. A gravel-covered nature trail bisects the site. A sign indicating the presence of both the archaeological site and a fossil bed is located at the head of the trail, the exact location of the site is not given on the sign.

\section{SITE SETTING}

Topography

The site is situated on a gently sloping lower portion of a ridge, about $100 \mathrm{~m}$ south of the Zorro Creek floodplain. The ground surface slopes downward to the northwest and north, from a bench on the southeastern edge of the site. The elevation at the site datum is approximately $327 \mathrm{~m}(1,072 \mathrm{ft})$ above mean sea level (amsl).

Soils

The soil at site 41VV1653 is from the Valverde series which consists of deep, well-drained valley fill on uplands, having a silty clay loam texture (Golden et al. 1982). However, the ground surface also contains large numbers of invertebrate fossils which have eroded out of limestone, limestone gravels, and hematite nodules. In some areas of the site these fossils, gravels, and nodules comprise as much as 90 percent of the ground surface, but within 1 to $2 \mathrm{~cm}$ below the modern ground surface they constitute only approximately 20 percent of the matrix. 


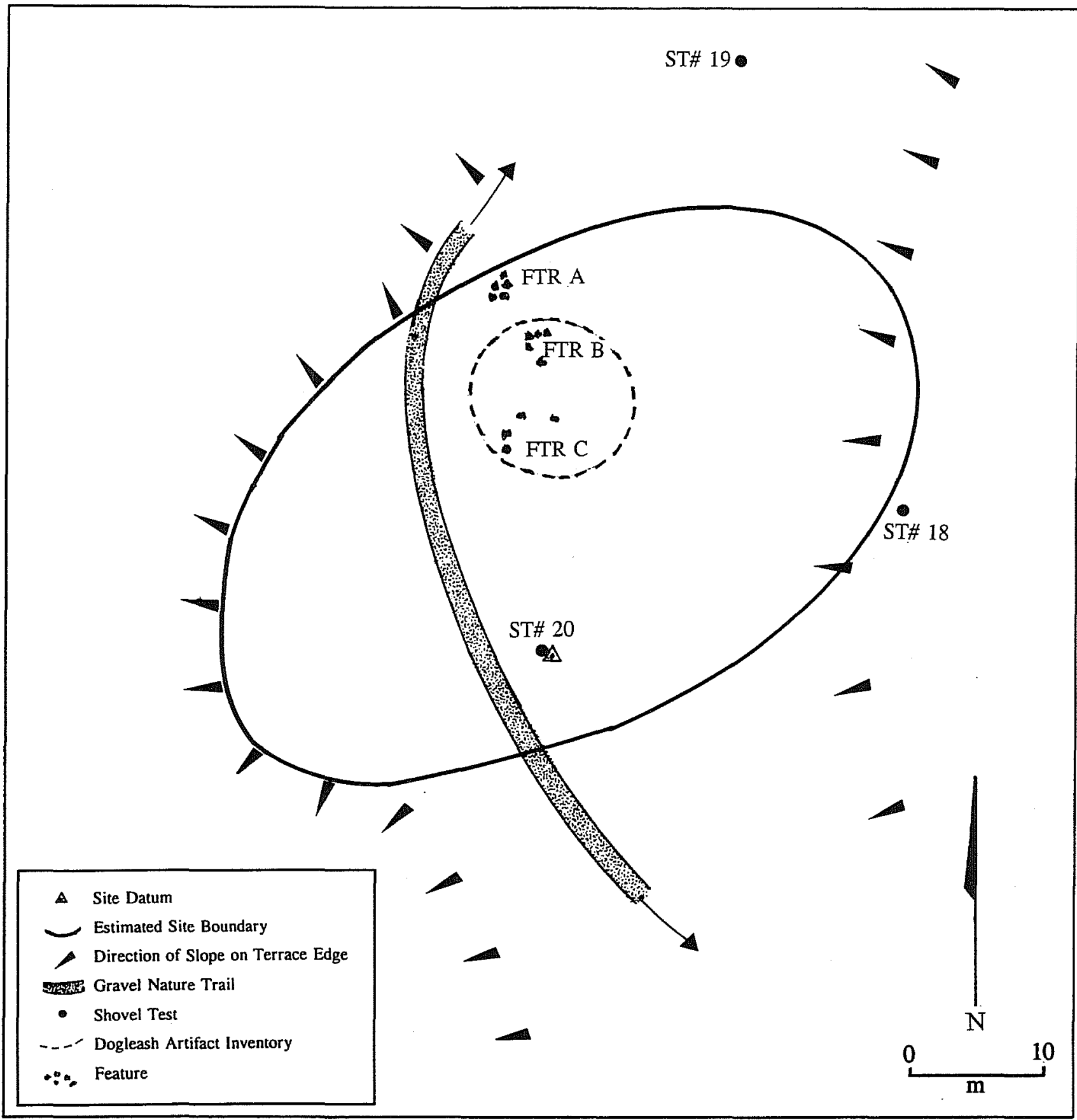

Figure 5-1. Site map, 41VV1653.

Vegetation

Site 41VV1653 is associated with Zorro Creek. Vegetation at the site is dominated by cenizo but also includes other woody plants and thorny brush species such as blackbrush acacia and catclaw. Small and medium xeric grasses including buffalograss, tobosa, curly mesquite, and fall witchgrass are also present (Everitt and Drawe 1993; Hatch and Pluhar 1993). The site vegetation is sparse, providing approximately 75 percent ground surface visibility.

\section{SITE DESCRIPTION}

Site 41VV1653 is a thin scatter of prehistoric lithic material located on a gently sloping terrace. Its dimensions are approximately $40 \times 45 \mathrm{~m}$, or ca. $1,800 \mathrm{~m}^{2}$, with the greatest width running northeastsouthwest (Figure 5-1). Cultural material observed on the surface includes a chert core and a few chert flakes. 
Features

Three cultural features were recorded for site 41VV1653 (Figure 5-1). Each feature is a loose concentration of thermally altered limestone, possibly representing hearth remnants. Feature A, located near the north-central boundary of the site, is comprised of 7 pieces of burned limestone ranging from 3 to $10 \mathrm{~cm}$ in width and occurring within a 1-m diameter area. Feature B, situated approximately $5 \mathrm{~m}$ southeast of Feature A, consists of 4 pieces of burned limestone, 4 to $5 \mathrm{~cm}$ in width, occurring within a $1-\mathrm{m}$ diameter area. Feature $\mathrm{C}$, located approximately $5 \mathrm{~m}$ south of Feature B, consists of 6 pieces of burned limestone within a $4-m$ diameter area.

Dogleash-Unit Inventories

Only one dogleash-unit artifact inventory (Figure 5-1) was performed for this site because of the limited site size and paucity of artifacts present on the ground surface. The inventoried artifacts are listed in Table 5-1.

Subsurface Testing

A single shovel test (ST 20), located within the south-central part of the site (Figure 5-1), was excavated at 41VV1653. Soil color changes were noted at $10 \mathrm{~cm}$ and $45 \mathrm{~cm}$ within the $45-$ to $50-\mathrm{cm}$ deep shovel test. At a depth of $45 \mathrm{~cm}$ below the modern ground surface, the matrix was composed of 50 percent caliche, fossils, sand, and gravels. This shovel test yielded no cultural material.

To test the possibility that the cultural material observed on the site surface was eroded from a buried site and/or that the bench above the site might contain undisturbed cultural deposits, two additional shovel tests (STs 18 and 19) were excavated. One shovel test was located outside the northeastern boundary of the site, the other shovel test was located outside the southeastern boundary. No cultural material was recovered from either of these two nonsite shovel tests.

\section{DISCUSSION}

Cultural material recorded for the single dogleash unit, and that observed elsewhere on the site, consisted of chert debitage. This debitage was comprised mainly of tertiary flakes, but also included secondary and primary flakes and a single chert core. No cultural material was recovered from the shovel tests excavated in and around site 41VV1653.

Table 5-1. Dogleash-Unit Inventory for Prehistoric Site 41VV1653

\begin{tabular}{|c|c|}
\hline Artifact Type & $\begin{array}{c}\text { Dogleash } \\
\text { Unit \#1 }\end{array}$ \\
\hline Primary flakes & 1 \\
\hline Secondary flakes & 3 \\
\hline Tertiary flakes & 16 \\
\hline Retouched flakes & 0 \\
\hline Unifaces (and fragments) & 0 \\
\hline Bifaces (and fragments) & 0 \\
\hline Projectile points (and fragments) & 0 \\
\hline Cores & 1 \\
\hline Tested cobbles & 0 \\
\hline Heat-spalled chert & 0 \\
\hline Thermally altered limestone & 10 \\
\hline Total & 31 \\
\hline
\end{tabular}


While evidence from the three shovel tests suggests the absence of subsurface cultural deposits, the three burned rock features warrant further investigation. This site has potential to contribute information about prehistoric adaptations in this portion of the Lower Pecos region and is recommended as eligible for nomination to the National Register of Historic Places under Criterion D. In order to develop a data recovery plan, additional testing would be required.

\section{VV1654}

Site 41VV1654 (Figure 5-2) is a large, multicomponent site first recorded by De Vore (1993) during a preliminary site survey in 1992 and reinvestigated by CAR staff during the current project. The site is situated on the east-central side of the base and is associated with Sacatosa Creek.

\section{SITE SETTING}

\section{Topography}

Most of site 41VV1654 is on the T2 terrace above Sacatosa Creek. However, to some extent the site extends eastward into the creek floodplain (T0). The elevation at the site datum is approximately $320 \mathrm{~m}$ $(1,050 \mathrm{ft})$ amsl, and ranges from $314 \mathrm{~m}(1,030 \mathrm{ft})$ to $323 \mathrm{~m}(1,060 \mathrm{ft})$ within the site.

\section{Soils}

The soils within the site consist of three types -Pintas, Zapata, and Coahuila-which occur in roughly north-south trending bands (Golden et al. 1982). The Pintas soil series consist of deep, somewhat poorly drained clays and silty clays (Golden et al. 1982:75) located in the creek bottomlands. The Zapata series soils consist of shallow, well-drained, gravelly and loamy soils located in upland areas and are formed by alluvial outwash over thick beds of caliche (Golden et al. 1982:81). The Zapata series soils are located in the western part of the site, particularly in the westcentral area. The soils occurring between these two series are from the Coahuila series, consisting of deep, well-drained loamy clay alluvium on old stream terraces and low uplands (Golden et al. 1982:67). The majority of the site has Coahuila series soils.

\section{Vegetation}

The eastern edge of site 41VV1654 is located within the floodplain, while the remainder of the site is on the second terrace. The vegetation within the site changes with increasing distance from Sacatosa Creek; these vegetational changes appear to generally co-vary with soil changes. Dense vegetation is present at the eastern edge of the site 41VV1654 and within some drainage bottoms in the central part of the site. Vegetation includes large mesquite trees, whitebrush, yaupon, thick stands of switchgrass, sunflower, and even some greenbriar, in addition to other relatively mesic plants.

The vegetational change from the lowland mesic to xeric varieties on the upper terrace is abrupt, and occurs roughly where the Pintas clays change to Coahuila clays. Cenizo dominates the upland xeric vegetation, accompanied by blackbrush acacia, Texas paloverde, catclaw, crucifixion thorn, and several varieties of short grasses. Additionally, Texas prickly pear, tasajillo, and strawberry cactus, are common. Century plants and maguey also are present, but are less common.

Within the highest area of the site, along the western site boundary where the Zapata series soils are found, the plant species are essentially the same as those listed above, but are significantly smaller and more stunted. Agave species are somewhat more common in this part of the site, as are blackbrush acacia and catclaw.

As a result of the variation in vegetation, the site surface visibility varies. At the eastern site boundary, where mesic plants proliferate, ground surface visibility is very poor, averaging less than 10 percent. Within the more open upland areas which comprise the majority of the site, the ground surface visibility is between 50 and 70 percent.

\section{SITE DESCRIPTION}

Site 41VV1654 (Figure 5-2) is extensive and has both prehistoric and historic components. The prehistoric component is detailed here, the historic component in Chapter 9. The site measures approximately $1,330 \mathrm{~m}$ north-south by $440 \mathrm{~m}$ east-west, with a total area of ca. $585,200 \mathrm{~m}^{2}$. The military has used the site and the surrounding vicinity as a training area for a number of years. Numerous dirt roads, deep 


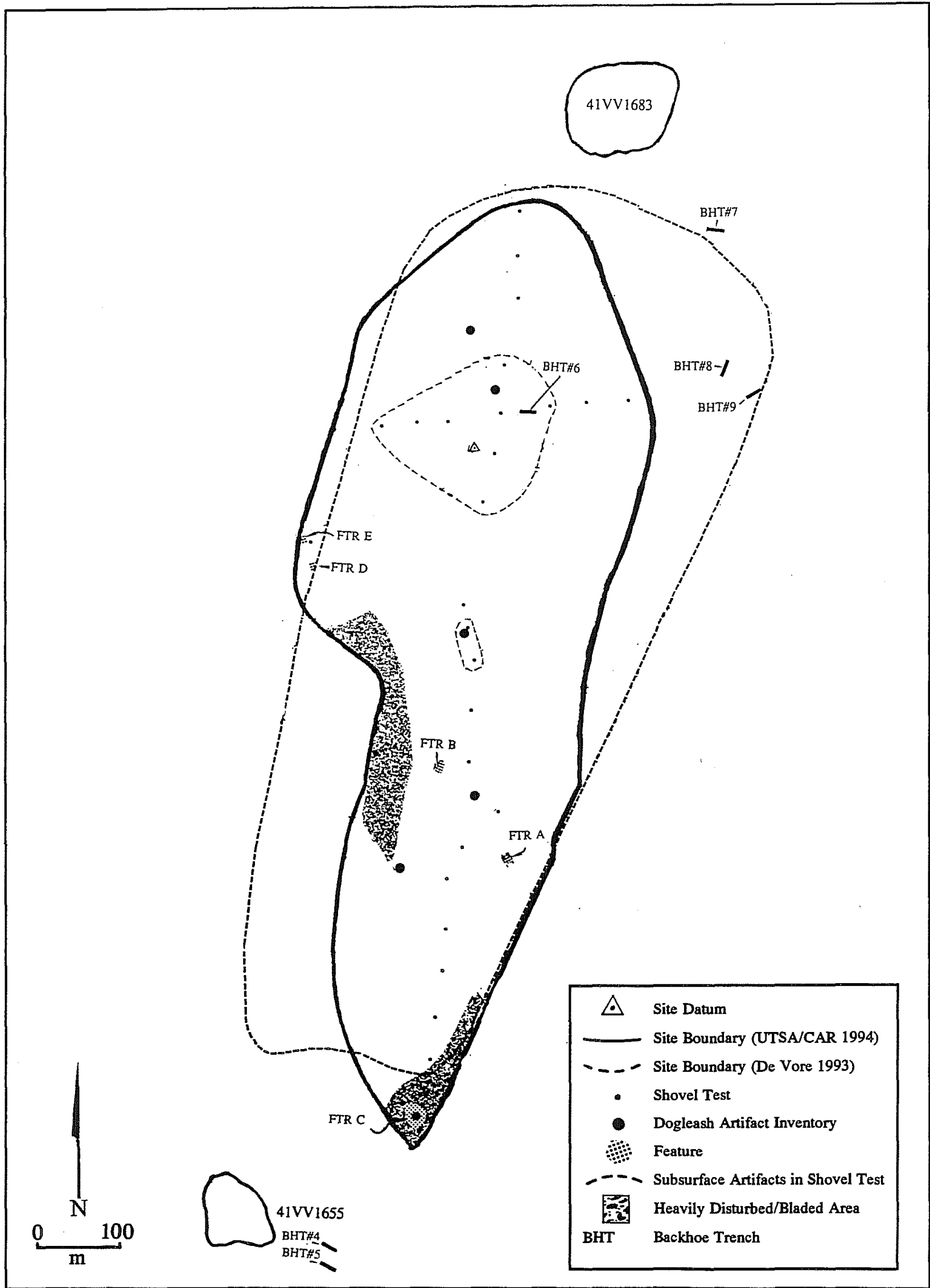

Figure 5-2. Site map, 41VV1654. 
bunkers, and other disturbances are evident, especially in the central part of the site. Lithic material is present across the entire site, with the densest concentration of cultural material, including most of the recorded formal lithic tools, occurring in the northern third of the site. The three diagnostic dart points-Golondrina/Barber, Wilson, and reworked Gower- recovered from the northern part of the site indicate it includes late Paleoindian ( 9800 to 9400 B.P.) and Early Archaic (8900 to 5500 B.P.) components. Additionally, at least two areas within the site contain cultural features and artifacts dating to the last quarter of the nineteenth century and to the 1920 s to 1940 s.

\section{Features}

Two prehistoric cultural features, $\mathrm{A}$ and $\mathrm{B}$, were observed within site 41VV1654. Both features are clusters of thermally altered limestone river cobbles possibly representing hearth remnants. Feature A (Figure 5-3), located in the southeastern part of the site (Figure 5-2), was exposed in an eroded dirt roadbed and occurred approximately 10 to $15 \mathrm{~cm}$ below the modern ground surface. A scatter of chert flakes was associated with this feature, but no diagnostic artifacts were observed. Feature B was located in the south-central part of the site (Figure 5-2) and consisted of 6 to 8 burned limestone cobbles clustered within an area approximately $1 \mathrm{~m}$ in diameter. Numerous other, less well-defined concentrations of thermally altered limestone were observed on the surface and in roadcuts and other disturbed areas within the site. Most of these possible features, which may also represent disturbed hearth remnants, were located in the southern part of the site.

Three historic features were identified on site 41VV1654. For discussion of the historic component, see Chapters 8 through 10.

\section{Dogleash-Unit Inventories}

Six dogleash units were performed within site 41VV1654 (Figure 5-2). Dogleash Unit \#1 was located in the central part of a primarily historic artifact scatter, in the southeastern part of the site. Prehistoric objects found in Dogleash Unit \#1 are listed in Table 5-2; historic artifacts are presented in Chapter 9. Only prehistoric artifacts were observed within the remaining five dogleash units (Table 5-2).

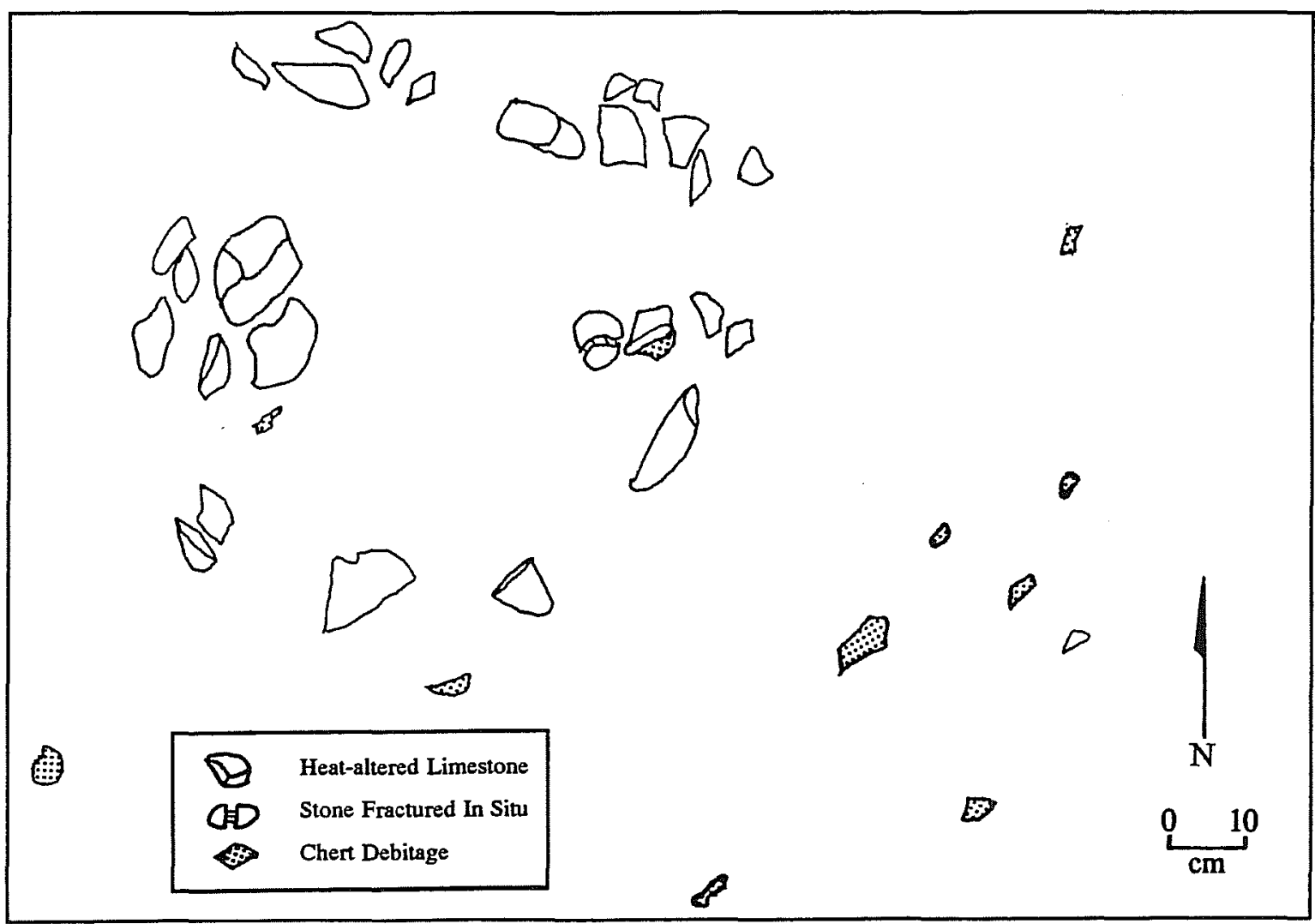

Figure 5-3. Feature $A$, site 41VV1654. 
Table 5-2. Dogleash-Unit Inventories for Site 41VV1654, Prehistoric Components

\begin{tabular}{|c|c|c|c|c|c|c|}
\hline Artifact Type & $\begin{array}{l}\text { Dogleash } \\
\text { Unit \#1 }\end{array}$ & $\begin{array}{l}\text { Dogleash } \\
\text { Unit \#2 }\end{array}$ & $\begin{array}{l}\text { Dogleash } \\
\text { Unit \#3 }\end{array}$ & $\begin{array}{l}\text { Dogleash } \\
\text { Unit \#4 }\end{array}$ & $\begin{array}{l}\text { Dogleash } \\
\text { Unit \#5 }\end{array}$ & $\begin{array}{c}\text { Dogleash } \\
\text { Unit \#6 }\end{array}$ \\
\hline Primary flakes & 0 & 13 & 1 & 1 & 7 & 2 \\
\hline Secondary flakes & 0 & 34 & 9 & 4 & 45 & 12 \\
\hline Tertiary flakes & 6 & 84 & 27 & 0 & 21 & 25 \\
\hline Retouched flakes & 0 & 0 & 3 & 0 & 0 & 0 \\
\hline Unifaces (and fragments) & 0 & 0 & 3 & 0 & 0 & 0 \\
\hline Bifaces (and fragments) & 1 & 0 & 0 & 0 & 2 & 1 \\
\hline $\begin{array}{l}\text { Projectile points } \\
\text { (and fragments) }\end{array}$ & 0 & 0 & 1 & 0 & 0 & 0 \\
\hline Cores & 0 & 4 & 0 & 0 & 1 & 1 \\
\hline Tested cobbles & 0 & 0 & 0 & 0 & 0 & 1 \\
\hline Heat-spalled chert & 0 & 0 & 4 & 1 & 0 & 0 \\
\hline Thermally altered limestone & 0 & 0 & 7 & 0 & 0 & 118 \\
\hline Total & 7 & 135 & 55 & 6 & 76 & 160 \\
\hline
\end{tabular}

Subsurface Testing

Twenty-eight shovel tests (STs 44-49, 69-88, and 90-91) were excavated within site 41VV1654 (Figures 5-2 and 5-4). The shovel tests ranged from 10 to $50 \mathrm{~cm}$ in depth, with the depths of the excavations varying according to the depth of the sediment composing the site deposits.

Cultural material, consisting entirely of chert flakes, was recovered from 12 of the 28 (42.9 percent) shovel tests (Table 5-3). Of the 12 shovel tests yielding cultural material, six (STs 48, 49, and 72-75) were within the north-central part of the site (Figures 5-2 and 5-4). Within four of these shovel tests (STs 48, 49, 74, and 75), cultural material was recovered from as deep as $50 \mathrm{~cm}$.

Three shovel tests (STs 78, 90, and 91) located in the central part of the site (Figure 5-4) also yielded subsurface cultural lithic material. Material was recovered to a depth of 40 to $50 \mathrm{~cm}$ in ST 91, and from 30 to $40 \mathrm{~cm}$ in ST 90 .

In the southern part of the site, one shovel test (ST 84) yielded prehistoric cultural material from a depth of 0 to $20 \mathrm{~cm}$. Historic material was recovered from a second shovel test (ST 88), located within Feature C, as deep as $20 \mathrm{~cm}$.

\section{DISCUSSION}

Site 41 VV1654 is an extensive prehistoric and historic site extending from the Sacatosa Creek floodplain to the second terrace. Evidence suggests a long-term use of the site by prehistoric people and historic peoples, from the Late Paleoindian through Early Archaic periods and from the late nineteenth century to the 1940s. No evidence of Middle Archaic to Late Prehistoric occupation of the site was found; however, only a very small part of this large site has been tested. The similarity between the trough features (Features D and E) and the trough feature (Feature A) in site 41VV1682 (the Zacatosa Ranch headquarters), strongly suggest that Features D and $\mathrm{E}$ are associated with the ranch. Detailed consideration of the historic component is found in Chapter 9 .

The prehistoric surface artifacts were most evident in the northern part of the site, on the upper terrace. Much of the cultural material is exposed and apparent along the edges of various dirt roads cutting through this part of the site. Most (17 of 18 , or 94.4 


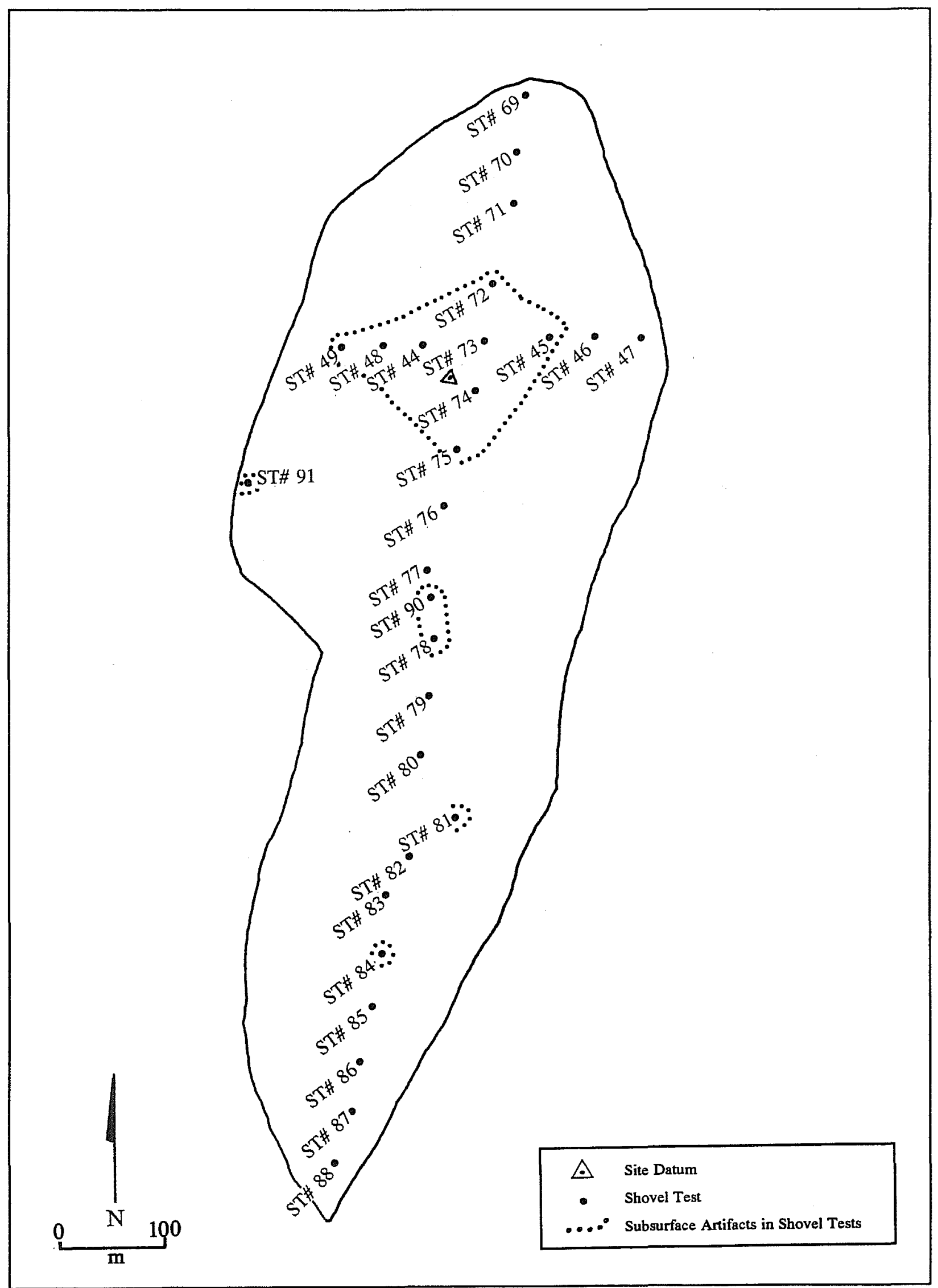

Figure 5-4. Shovel test locations, site 41VV1654. 
Table 5-3. Shovel Tests and Levels which Produced Artifacts on Site 41VV1654

\begin{tabular}{|c|c|c|c|c|c|}
\hline Shovel Tests & $\begin{array}{l}0 \text { to } 10 \\
\mathrm{~cm}\end{array}$ & $\begin{array}{c}10 \text { to } 20 \\
\mathrm{~cm}\end{array}$ & $\begin{array}{c}20 \text { to } 30 \\
\mathrm{~cm}\end{array}$ & $\begin{array}{c}30 \text { to } 40 \\
\mathrm{~cm}\end{array}$ & $\begin{array}{c}40 \text { to } 50 \\
\text { cm }\end{array}$ \\
\hline ST 48 & $X$ & $X$ & $\mathrm{X}$ & & $X$ \\
\hline ST 49 & $X$ & $\mathrm{X}$ & & & $X$ \\
\hline ST 72 & $\mathrm{X}$ & & $X$ & & \\
\hline ST 73 & & $\mathrm{X}$ & & $X$ & \\
\hline ST 74 & $\mathrm{X}$ & & & & $X$ \\
\hline ST 75 & & & & $\mathrm{X}$ & $\mathrm{X}$ \\
\hline ST 78 & $\mathrm{X}$ & $\mathrm{X}$ & & & \\
\hline ST 81 & $\mathrm{X}$ & & & & \\
\hline ST 84 & $X$ & $X$ & & & \\
\hline ST 88 & $\mathrm{X}^{*}$ & $\mathrm{X}^{*}$ & & & \\
\hline ST 90 & $X$ & & $\mathrm{X}$ & $\mathrm{X}$ & \\
\hline ST 91 & & & $\mathrm{X}$ & & $\mathrm{X}$ \\
\hline
\end{tabular}

*Historic period artifacts

percent) of the formal tools observed within the site were found in this northern area, including the three prehistoric diagnostic projectile points (Golondrina/ Barber, Wilson, and a reworked Gower dart point), numerous thin bifaces, unifaces, and one limestone pestle. The dart points date to the late Paleoindian ( 9400 to 8800 B.P. for the Golondrina/Barber point) and Early Archaic (8900 to 5500 B.P. for the Wilson and Gower points) periods.

Inventories from the two northern dogleash units indicate the density of lithic debitage was relatively sparse, in comparison to the central part of the site, and consisted mainly of tertiary flakes, with lesser amounts of secondary flakes and very few primary flakes. Eight of the 11 shovel tests yielding subsurface cultural material were located nearby in the northern part of the site. A Golondrina/ Barber point was found in situ and collected from the profile of a military foxhole, at a depth of $33 \mathrm{~cm}$ below the modern ground surface; the backdirt from this same foxhole yielded the only ground stone artifact, a pestle, found within the project area.

Most of site 41VV1654 is on the T2 terrace, but the site also extends into the floodplain to the east. Much of this area has been disturbed by the construction of dirt roads, military bunkers, and other military structures. The density of lithic debitage inventoried in three central dogleash units indicates chipped stone debris on the surface is greatest here. However, no formal tools were found in this part of the site. Subsurface material was recovered to a maximum depth of 40 to $50 \mathrm{~cm}$ in five shovel tests in this area.

The southern to southeastern portion of site 41 VV1654 is predominantly located within the floodplain, although the western edge of this area is on the alluvial terrace. Relatively limited construction disturbance is evident here, although the dense vegetation might obscure older disturbances. Blading by heavy machinery was most evident in the southernmost part of the site. The dogleash-unit inventory conducted in this bladed area showed a sparse scatter of lithic debris consisting of chert tertiary flakes and one biface. Generally, limited amounts of lithic debitage were observed on the surface in this part of the site, although such material may have been obscured by dense vegetation. Five shovel tests were excavated within this part of the site, two of which yielded subsurface cultural material. 
Overall, the shovel test results suggest that the deeper subsurface cultural deposits $(20 \mathrm{~cm}$ or more below the modern ground surface) at 41VV1654 are restricted to the central and northern areas. The lack of formal tools in the central and southern part of the sites may be due to the heavier use of these areas by military personnel. Due to its size, integrity, and potential for buried deposits, site 41VV1654 has high research potential and could contribute significantly to our understanding of Late Paleoindian and Early Archaic adaptation.

This site is one in a cluster of sites within the Sacatosa Creek drainage and has the potential to contribute substantial data to the understanding of past human adaptations in this area of the Lower Pecos. Site 41VV1654 is recommended as eligible for nomination to the National Register of Historic Places under Criterion D. In order to develop a data recovery plan, additional testing would be required.

\section{$41 V V 1655$}

Site 41VV1655 (Figure 5-5) is the third of three sites originally recorded by De Vore (1993) in 1992 and revisited by CAR archaeologists during the current project. This site is a prehistoric lithic scatter on the $\mathrm{T} 2$ terrace in the creek zone, on a high point above the juncture of Sacatosa Creek and an unnamed intermittent tributary. It has been disturbed by the blading of a dirt road along its western boundary and by the construction of a short spur of dirt road into the site. Additionally, a large cabin-style deer blind was constructed within the site, causing further disturbance. The general area has been used for military training and hunting.

\section{SITE SETTING}

\section{Topography}

Site 41VV1655 is situated on a point above the juncture of two water courses, Sacatosa Creek and an unnamed tributary. The modern ground surface sharply slopes downward on all but the western side. The elevation at the site datum is $321 \mathrm{~m}(1,050 \mathrm{ft})$ amsl.
Soils

The site soils are from the Coahuila series and consist of deep, well-drained loamy clay alluvium on old stream terraces and low uplands (Golden et al. 1982). Some erosion along the edge of the terrace is evident.

\section{Vegetation}

The vegetation on site 41VV1655 consists largely of cenizo, blackbrush acacia, Texas prickly pear, and mesquite. Grasses are short, xeric varieties. Vegetation density is moderate, except in the disturbed areas, where the plant density is low.

\section{SITE DESCRIPTION}

Site 41VV1655 is a lithic scatter situated on the upland T2 terrace between Sacatosa Creek and an unnamed tributary. The site measures approximately $50 \times 90 \mathrm{~m}$, or roughly $4,500 \mathrm{~m}^{2}$ in area, with the length oriented east-west (Figure 5-5). It is located within a hunting area for base personnel. A large, enclosed deer blind has been constructed on the site, at the terrace edge, and a bladed dirt road leads to the deer blind. Erosion is evident along the steep eastern edge of the terrace.

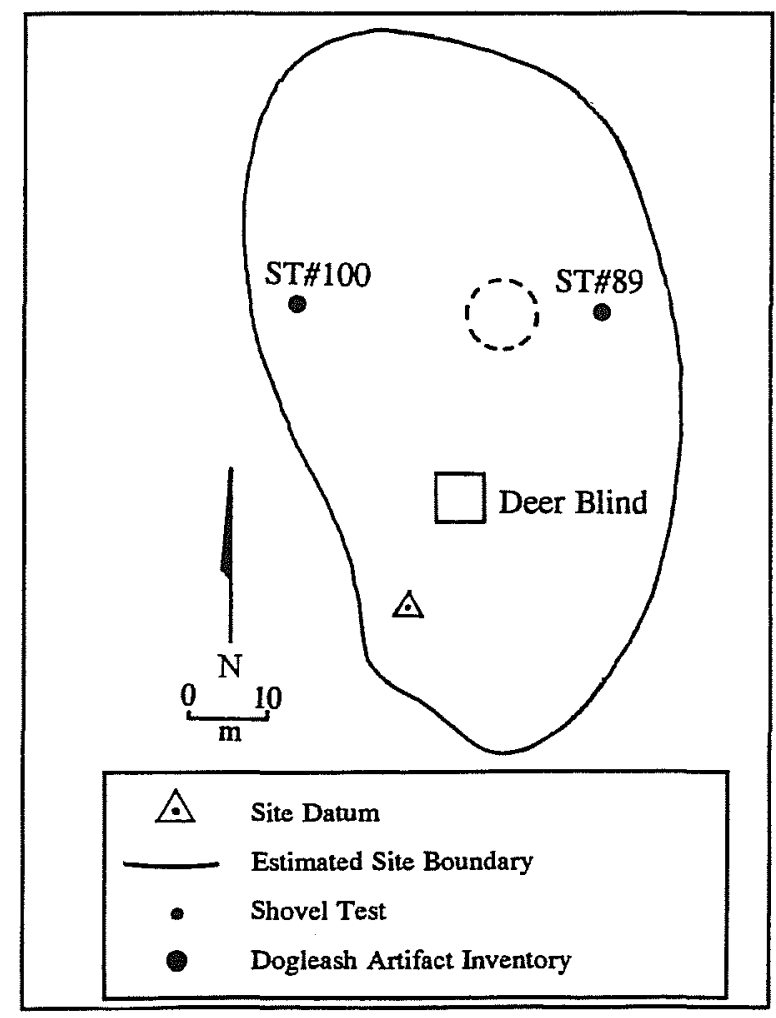

Figure 5-5. Site map, 41VV1655. 
Cultural material observed on the ground surface includes chert cores, flakes, and tested chert cobbles. Unmodified chert cobbles are exposed on the ground surface of the site.

\section{Features}

No prehistoric cultural features were observed at this site.

\section{Dogleash-Unit Inventories}

Due to the limited horizontal extent and limited amount of cultural material, only one dogleash-unit inventory was conducted (Figure 5-5). The results are summarized in Table 5-4.

Subsurface Testing

The depths of the two shovel tests (STs 89 and 100) excavated in site 41VV1655 were dependant upon the levels at which bedrock was encountered. In ST 89 , located near the terrace edge in the eastern part of the site (Figure 5-4), the sediments were a light brown sandy silt with limestone cobbles, gravels, and pebbles. Cultural material, consisting of unmodified and modified primary and secondary chert flakes, was recovered from a maximum depth of $20 \mathrm{~cm}$ (Table 5-5).

Bedrock was reached at $45 \mathrm{~cm}$. ST 100, located in the western part of the site (Figure 5-5), also had light brown sandy silt, with almost 90 percent of the volume comprised of limestone cobbles, gravels, and pebbles. Bedrock was reached at $15 \mathrm{~cm}$ in this shovel test. No artifacts were recovered from this test.

Table 5-4. Dogleash-Unit Inventory for Prehistoric Site 41VV1655

\begin{tabular}{|c|c|}
\hline Artifact Type & $\begin{array}{c}\text { Dogleash } \\
\text { Unit \#1 }\end{array}$ \\
\hline Primary flakes & 12 \\
\hline Secondary flakes & 16 \\
\hline Tertiary flakes & 2 \\
\hline Retouched flakes & 0 \\
\hline Unifaces (and fragments) & 0 \\
\hline Bifaces (and fragments) & 0 \\
\hline Projectile points (and fragments) & 0 \\
\hline Cores & 4 \\
\hline Tested cobbles & 10 \\
\hline Heat-spalled chert & 0 \\
\hline Thermally altered limestone & 0 \\
\hline Total & 44 \\
\hline
\end{tabular}

Table 5-5. Shovel Tests and Levels which Produced Artifacts on Site 41VV1655

\begin{tabular}{|c|c|c|c|c|c|}
\hline Shovel Tests & $\begin{array}{c}0 \text { to } 10 \\
\mathrm{~cm}\end{array}$ & $\begin{array}{c}10 \text { to } 20 \\
\mathrm{~cm}\end{array}$ & $\begin{array}{c}20 \text { to } 30 \\
\mathrm{~cm}\end{array}$ & $\begin{array}{c}30 \text { to } 40 \\
\mathrm{~cm}\end{array}$ & $\begin{array}{c}40 \text { to } 50 \\
\mathrm{~cm}\end{array}$ \\
\hline ST 89 & $\mathrm{X}$ & $\mathrm{X}$ & & & \\
\hline
\end{tabular}




\section{DISCUSSION}

Site 41VV1655 is a sparse lithic scatter, associated with Sacatosa Creek, located at the edge of the high T2 terrace where gravels, including chert pebbles and cobbles, are exposed. The results of one shovel test indicate the presence of subsurface cultural deposits.

This site is one in a cluster of sites within the Sacatosa Creek drainage and has the potential to contribute substantial data to the understanding of past human adaptations in this area of the Lower Pecos. Site 41VV1655 is recommended as eligible for nomination to the National Register of Historic Places under Criterion D. In order to develop a data recovery plan, additional testing would be required.
$41 V V 1683$

Site 41VV1683 (Figure 5-6) is located near the eastern boundary of the base. This prehistoric site consists of a moderately dense scatter of chert artifacts and debitage in the creek zone.

\section{SITE SETTING}

\section{Topography}

Site 4IVV1683 is located on a gentle slope of the T2 terrace, overlooking the floodplain on the west side of a small, unnamed, intermittent tributary of Sacatosa Creek. The site extends into the floodplain of the tributary, almost to the channel. The elevation

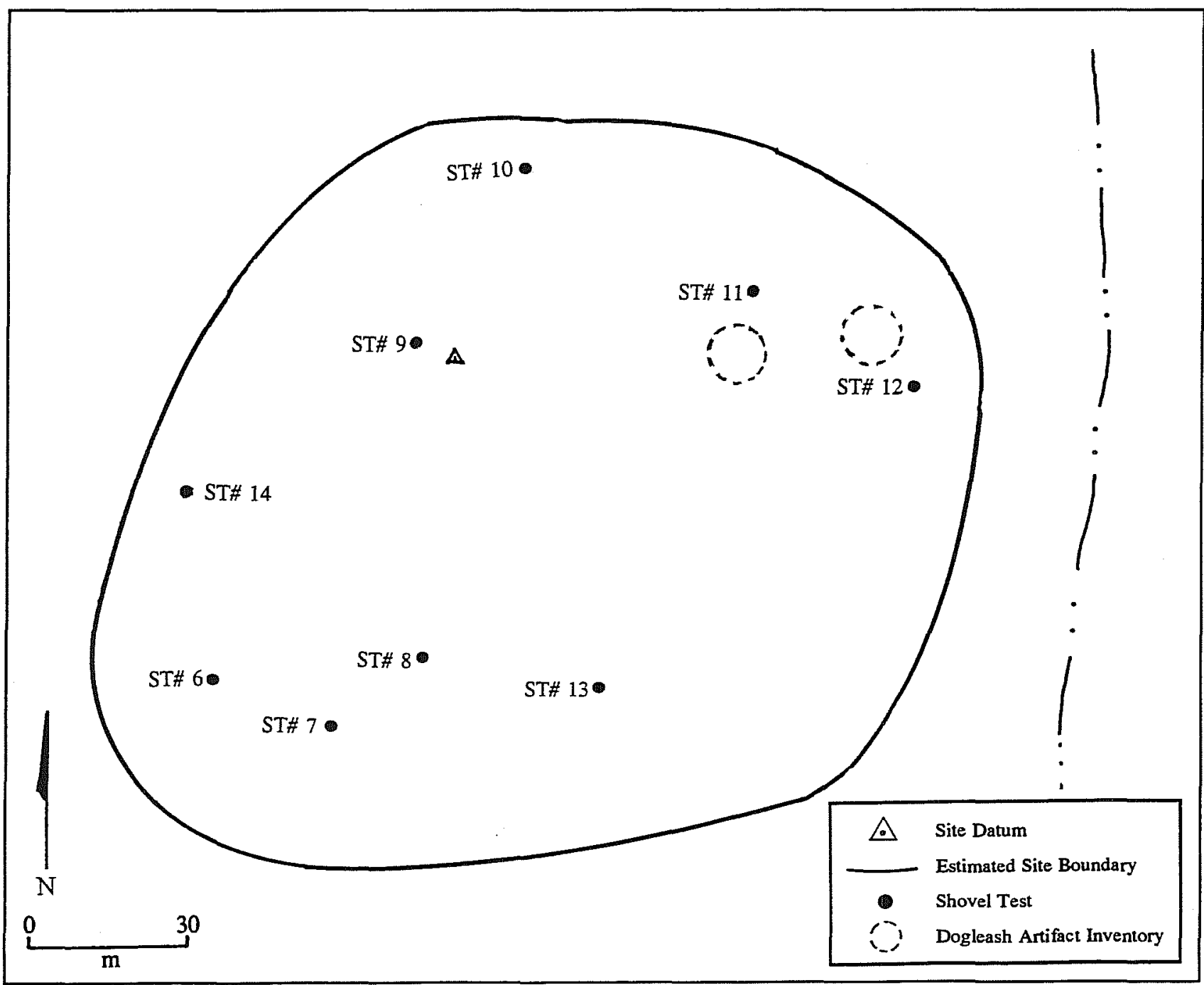

Figure 5-6. Site map, 41VV1683. 
at the site datum is approximately $321 \mathrm{~m}(1,050 \mathrm{ft})$ amsl. While most of the site is on an upland landform, it is within $100 \mathrm{~m}$ of the floodplain; therefore, it falls within the creek zone.

\section{Soils}

The site soils are from the Acuna series, which consists of deep, nearly level soils found on stream terraces and low uplands (Golden et al. 1982:17-18, Map 55).

\section{Vegetation}

Site 41VV1683 is associated with the creek and contains both xeric and mesic species. The vegetation on the upper part of the site is largely cenizo, with many large mesquite, and grasses such as sideoats grama (Bouteloua curtipendula), plains bristlegrass (Setaria leucopila), and buffalograss. Closer to the creek are desert hackberry, guayacan, and chapote, as well as fall witchgrass and other tall grasses (Everitt and Drawe 1993; Hatch and Pluhar 1993). The vegetation on the site is fairly dense, making visibility of the ground surface poor, approximately 20 percent.

\section{SITE DESCRIPTION}

Site 41VV1683 consists of a moderately dense scatter of chert artifacts and debitage, including exhausted cores, retouched flakes, thick bifaces, a triangular biface, one Late Paleoindian Angostura dart point fragment, and a possible hammerstone. The site measures approximately $120 \times 135 \mathrm{~m}$, or $16,200 \mathrm{~m}^{2}$. Part of the southwestern portion of the site has been bladed for a dirt road (Figure 5-6).

\section{Features}

No well-defined cultural features were observed within 41VV1683, although thermally altered limestone was visible in some places in the western part of the site.

\section{Dogleash-Unit Inventories}

Two dogleash units were conducted on the eastern side of site 41VV1683 (Figure 5-6). Dogleash Unit \#1 is located in an area with what was judged to be an average artifact density. Dogleash Unit \#2 was conducted in an area of the site with the highest surface artifact density. Table 5-6 shows the results of these inventories.

Table 5-6. Dogleash-Unit Inventory for Prehistoric Site 41VV1683

\begin{tabular}{|c|c|c|}
\hline Artifact Type & $\begin{array}{c}\text { Dogleash } \\
\text { Unit \#1 }\end{array}$ & $\begin{array}{c}\text { Dogleash } \\
\text { Unit } \# 2\end{array}$ \\
\hline Primary flakes & 7 & 11 \\
\hline Secondary flakes & 3 & 2 \\
\hline Tertiary flakes & 4 & 3 \\
\hline Retouched flakes & 0 & 5 \\
\hline Unifaces (and fragments) & 0 & 0 \\
\hline Bifaces (and fragments) & 1 & 0 \\
\hline Projectile points (and fragments) & 0 & 0 \\
\hline Cores & 0 & 3 \\
\hline Tested cobbles & 0 & 0 \\
\hline Heat-spalled chert & 0 & 1 \\
\hline Thermally altered limestone & 0 & 1 \\
\hline Total & 15 & 26 \\
\hline
\end{tabular}


Subsurface Testing

Nine shovel tests (STs 6-14) were excavated at site 41VV1683 (Figure 5-6). No discernable soil change was evident in six of these shovel tests. One test (ST 11) did have numerous large $(8$ to $12 \mathrm{~cm}$ ) chert nodules at a depth of 20 to $35 \mathrm{~cm}$. In ST 8, located in the southwestern part of the site, a layer of medium brown silty clay extended to $12 \mathrm{~cm}$, and was followed by a layer of caliche gravels to $20 \mathrm{~cm}$. At $20 \mathrm{~cm}$ a layer of almost solid caliche blocks was uncovered, at which point the excavation was stopped.

Five of the nine tests yielded chert artifacts (Table 5-7). In ST 7 chert debitage, consisting of unmodified and modified secondary and tertiary flakes, was recovered from levels of 0 to $20 \mathrm{~cm}$ and from 30 to $50 \mathrm{~cm}$. Additionally, a thin biface fragment came from 0 to $10 \mathrm{~cm}$ in depth and small bone fragments (Sylvilagus sp., unidentified bird sp., and unidentifiable fragments) were recovered from a level 10 to $20 \mathrm{~cm}$ in depth.

\section{DISCUSSION}

41VV1683 is a small site, part of which has been disturbed by blading. The presence of an Angostura dart point suggests a Late Paleoindian component. The recovery of chert debitage to a depth of $50 \mathrm{~cm}$ indicates the presence of subsurface cultural deposits.

This site is one in a cluster of sites within the Sacatosa Creek drainage and has the potential to contribute substantial data to the understanding of past human adaptations in this area of the Lower Pecos. Site 41VV1683 is recommended as eligible for nomination to the National Register of Historic Places under Criterion D. In order to develop a data recovery plan, additional testing would be required.

\section{VV1684}

Site 41VV1684 (Figure 5-7) is located in the central part of the main base, in an open, mowed, grassy area near several parking lots. The site consists of two areas (designated Areas A and B) with sparse scatters of lithic debitage and thermally altered limestone, and a third area (Area C) which reportedly yielded numerous prehistoric artifacts (Donnie Stillwell, personal communication 1994). The site has been extensively disturbed by landscaping and by the construction of buildings, roads, and parking lots. Some of the buildings are no longer extant.

\section{SITE SETTING}

\section{Topography}

Due to modern construction activities, the original topography of the site is unknown. Generally, however, the site is in the upland zone about $2.8 \mathrm{~km}$ from Sacatosa Creek and $1.7 \mathrm{~km}$ from Zorro Creek. This site vicinity has the highest elevation, approximately $341 \mathrm{~m}(1,120 \mathrm{ft})$ amsl, and is the farthest from a creek of any location on the base.

Table 5-7. Shovel Tests and Levels which Produced Artifacts on Site 41VV1683

\begin{tabular}{||c||c|c|c|c|c||}
\hline Shovel Test & $\begin{array}{c}0 \text { to } 10 \\
\text { cm }\end{array}$ & $\begin{array}{c}10 \text { to } 20 \\
\text { cm }\end{array}$ & $\begin{array}{c}20 \text { to } 30 \\
\text { cm }\end{array}$ & $\begin{array}{c}30 \text { to } 40 \\
\text { cm }\end{array}$ & $\begin{array}{c}40 \text { to } 50 \\
\text { cm }\end{array}$ \\
\hline ST 7 & $\mathrm{X}$ & $\begin{array}{c}\mathrm{X} \\
\text { Bone }\end{array}$ & & $\mathrm{X}$ & $\mathrm{X}$ \\
\hline ST 8 & $\mathrm{X}$ & & & & \\
\hline ST 9 & $\mathrm{X}$ & & & & \\
\hline ST 10 & $\mathrm{X}$ & $\mathrm{X}$ & & & \\
\hline ST 12 & $\mathrm{X}$ & & & & \\
\hline
\end{tabular}




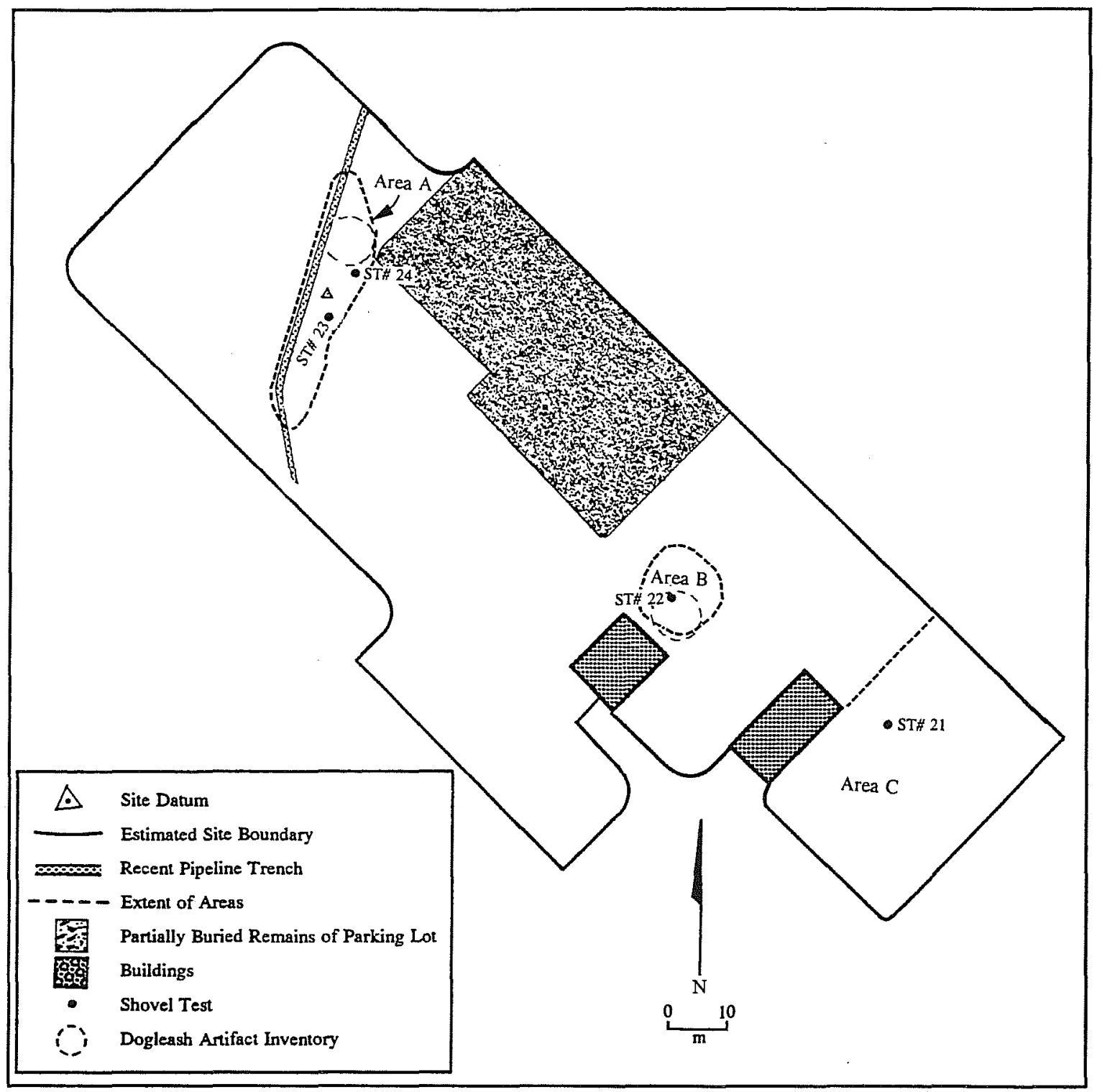

Figure 5-7. Site map, 41VV1684.

Soils

The soils in the area of site 41VV1684 are of the Zapata-Vinegarroon complex, a series of shallow soils on uplands formed on old outwash sediment over thick beds of caliche (Golden et al. 1982:43-44, Map 55). However, the site is located in a highly disturbed area, and at least some of the sediments currently at the site are fill brought in for construction and landscaping purposes.

\section{Vegetation}

Site 41VV1684 is located within the upland zone. However, the area of the site is maintained as a lawn, so vegetation consists almost entirely of Bermuda and other grasses. An occasional plant of false-mesquite (Calliandra confert), much stunted by mowing, is also present. The ground surface visibility at the site varied from approximately 5 percent where the grass was thick, to approximately 20 percent where the grass was less dense. The ground surface of a recent construction trench cut across the site and was visible.

\section{SITE DESCRIPTION}

Site 41VV1684 measures approximately $55 \times 160 \mathrm{~m}$, or approximately $8,800 \mathrm{~m}^{2}$ (Figure $5-7$ ). The site includes two areas (Areas $\mathrm{A}$ and $\mathrm{B}$ ) having thin scatters of prehistoric chert debitage on the surface. Additionally, numerous small to medium pieces ( 3 to $10 \mathrm{~cm}$ in diameter) of thermally altered limestone are 
associated with these scatters. A third area (Area C) adjacent to the lithic scatters was examined closely because an informant stated that at one time artifacts had been plentiful on the ground surface (Donnie Stillwell, personal communication 1994). Although no evidence of artifacts was currently evident in this area, it was included in the site boundaries.

Area $\mathrm{A}$ is located in the northern part of the site (Figure 5-7). It measures approximately $15 \times 40 \mathrm{~m}$, with the long axis oriented southwest to northeast. All the cultural material observed within Area A was located south of a narrow machine-dug trench. It is possible that at least part of the cultural material found on the ground surface in this area was from the backdirt of this trench.

Area B is located south of Area A, east of a barbecue and picnic area and northeast of a metal storage shed (Figure 5-7). This area is roughly circular in outline and measures approximately $10 \mathrm{~m}$ in diameter. The sparse scatter of chert debitage and thermally altered rock in this area seems to be associated entirely with what appears to be reddish-tan fill dirt dissimilar to the other soils in the area. This sediment may have been associated with a no-longer-extant building reportedly located here.
Area $C$ is located south of Area B. No artifacts were discovered either on the ground surface or in the shovel test that was excavated in this area. However, a local informant stated that a site, abundant with lithic artifacts, once located here was subsequently bladed, covered with a half-meter or more of imported fill dirt, and leveled (Donnie Stillwell, personal communication 1994). Area $C$ was included in the site because of the possibility that some portion of this reported site might still exist beneath the layers of fill.

\section{Features}

No cultural features were observed within the site.

Dogleash-Unit Inventories

Two dogleash-unit inventories were conducted at site 41VV1684. Dogleash Unit \#1 was located within Area A and Dogleash Unit \#2 was located in Area B (Table 5-8).

\section{Subsurface Testing}

Four shovel tests (STs 21-24) were excavated at site 41 V1684 (Figure 5-7). The shovel tests ranged from 9 to $50 \mathrm{~cm}$ in depth and none yielded cultural material. The profile of ST 21, located in Area C, shows a layer of dark grayish brown clay extending

Table 5-8. Dogleash-Unit Inventory for Prehistoric Site 41VV1684

\begin{tabular}{||l|c|c|}
\hline \multicolumn{1}{|c|}{ Artifact Type } & $\begin{array}{c}\text { Dogleash } \\
\text { Unit \#1 }\end{array}$ & $\begin{array}{c}\text { Dogleash } \\
\text { Unit \#2 }\end{array}$ \\
\hline Primary flakes & 0 & 0 \\
\hline Secondary flakes & 2 & 1 \\
\hline Tertiary flakes & 8 & 4 \\
\hline Retouched flakes & 0 & 0 \\
\hline Unifaces (and fragments) & 0 & 0 \\
\hline Bifaces (and fragments) & 0 & 0 \\
\hline Projectile points (and fragments) & 0 & 0 \\
\hline Cores & 0 & 0 \\
\hline Tested cobbles & 0 & 0 \\
\hline Heat-spalled chert & 0 & 0 \\
\hline Thermally altered limestone & 41 & 13 \\
\hline & $\mathbf{5 1}$ & $\mathbf{1 8}$ \\
\hline
\end{tabular}


from 0 to $8 \mathrm{~cm}$ below the modern ground surface. At $8 \mathrm{~cm}$ an abrupt shift to a clay/caliche mix containing numerous pea-sized gravels occurs. This layer continues to $48 \mathrm{~cm}$; below $48 \mathrm{~cm}$ is an almost solid layer of large caliche and limestone fragments. Due to the density of rock fragments, excavation was ended at $48 \mathrm{~cm}$. The sediment evident in the profile appears to be fill rather than naturally occurring sediments.

Another shovel test (ST 22) was located in the central part of Area B (Figure 5-7). The upper $2 \mathrm{~cm}$ of sediment was a reddish-tan sandy clay. From 2 to 26 $\mathrm{cm}$ below the modern ground surface was a hardpacked caliche and gravel fill. At a depth of 26 to 38 $\mathrm{cm}$, a yellowish brown, sandy silt layer was encountered. A solid layer of rock and gravel was reached at a depth of $38 \mathrm{~cm}$; excavation was ended at this level.

Two shovel tests (STs 23 and 24) were located in Area A (Figure 5-7). ST 23 was approximately $1 \mathrm{~m}$ south of the narrow machine-cut trench. The upper layer, 0 to $13 \mathrm{~cm}$ in depth, was a sandy silt, mottled reddish brown and medium brown in color. A single chert flake and 7 chunks of thermally altered limestone were recovered from the first $10 \mathrm{~cm}$ level. Below $13 \mathrm{~cm}$ was a hard-packed caliche and gravel layer, with asphalt adhering to some of the gravel; this layer appeared to be an old roadbed. The shovel test excavation was stopped at this depth. Subsequent examination of older maps of the base showed that this area was a parking lot for a hospital building.

The other shovel test in Area A (ST 24) was placed approximately $6 \mathrm{~m}$ east of the first. The same mottled sandy silt was encountered in this shovel test. Two pieces of fire-cracked limestone were recovered from 0 to $5 \mathrm{~cm}$ in depth. At a depth of 8 to $9 \mathrm{~cm}$, the hard-packed caliche and gravel fill that included some gravel with attached asphalt was encountered. The test was terminated at this depth.

\section{DISCUSSION}

Site 41VV1684 is the only prehistoric site on the base located in the upland zone; it is, unfortunately, highly to completely disturbed. The few cultural objects located at this site were from disturbed context and may have been imported with fill brought in for landscaping or construction. This site is not recommended as eligible for nomination to the National Register so further work is not required..

\section{VV1685}

Site 41 VV1685 (Figure 5-8) is a prehistoric site consisting of an extensive scatter of chert debitage. It is located on top of a highly dissected terrace rising some 9 to $12 \mathrm{~m}$ above Sacatosa Creek in an area used by local land owners to graze goats, horses, and cattle.

\section{SITE SETTING}

\section{Topography}

Site 41VV1685 is situated on the relatively level T2 terrace which slopes gently eastward toward Sacatosa Creek and is dissected by three large and numerous smaller arroyos (Figure 5-8). The terrace drops steeply downward to the creek and in some places, especially Area $B$, is precipitous. The elevation at the site datum is approximately $318 \mathrm{~m}(1,040 \mathrm{ft}) \mathrm{amsl}$; elevations within the site range from 314 to $321 \mathrm{~m}$ $(1,030$ to $1,050 \mathrm{ft})$. Outcrops of chert-bearing limestone bedrock are evident in numerous places within the site, especially along the edges of the terrace. Chert nodules, ranging in size from pebbles to moderately large cobbles (10 to $15 \mathrm{~cm}$ in diameter), are eroding out of the limestone bedrock.

Soils

The soils are very shallow or absent over most of the site. A few areas that have deep soils may represent filled arroyos. The soils within most of the site are of the Olmos series, consisting of shallow, very gravelly loam on old outwash deposits on uplands. Along the north and western boundaries of the site are some soils from the Coahuila series, consisting of well-drained, loamy clay alluvium on old stream terraces and low uplands (Golden et al. 1982).

Vegetation

Site 41VV1685, located on the $T 2$ terrace of Sacatosa Creek, supports xeric vegetation. The species present reflect the grazing of livestock and is thus dominated by woody shrubs, especially cenizo and blackbrush acacia. Other woody shrubs are catclaw, Texas paloverde, and guajillo. A few mesquite trees are present in the smaller arroyos. 


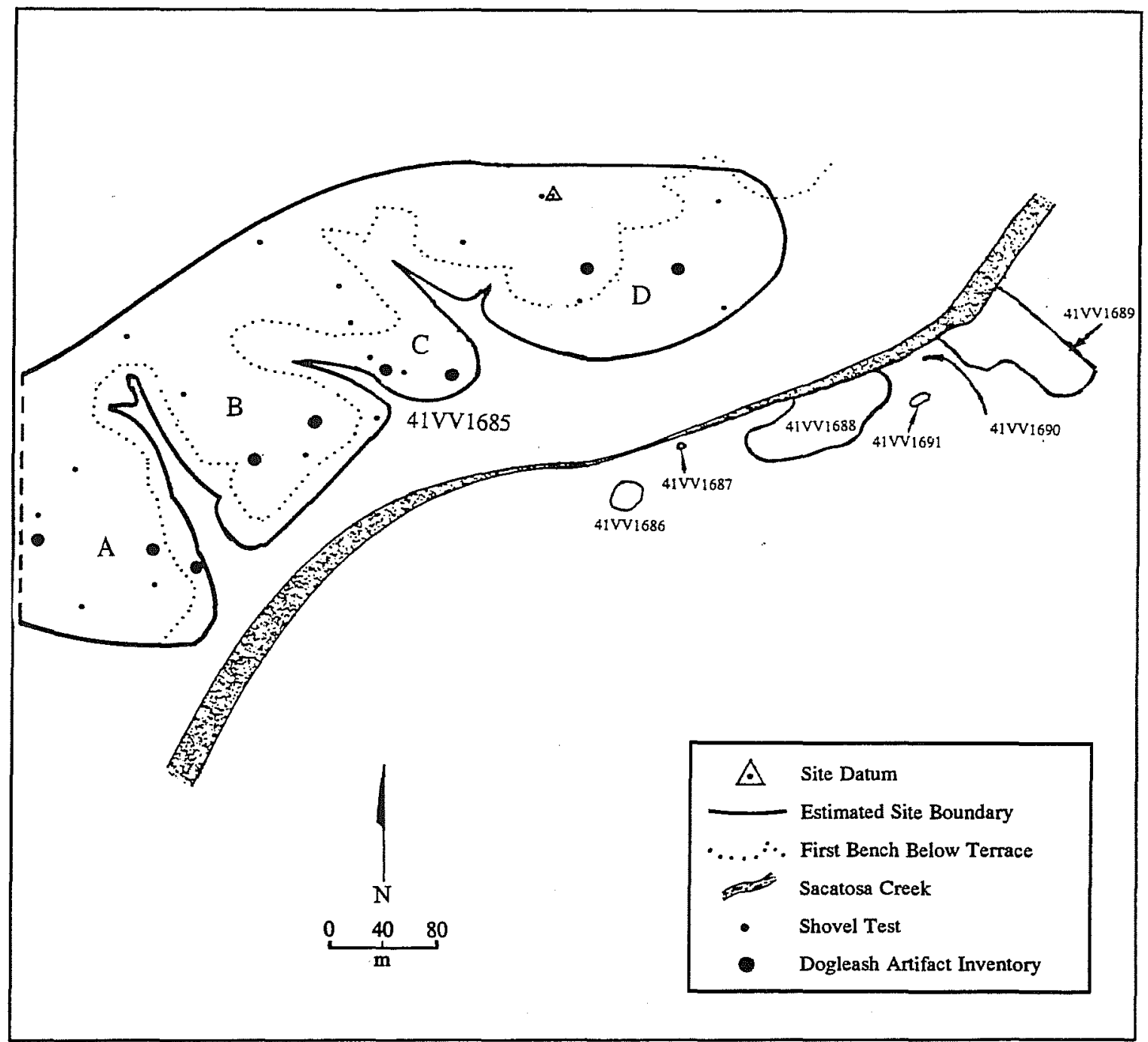

Figure 5-8. Site map, 41VV1685. A, B, C, and D denote site areas.

Grasses, mostly threeawn (Aristida purpurea), fall witchgrass, and curly mesquite, are located in some areas, as are Texas prickly pear, tasajillo, and strawberry cactus. Century plants and maguey also are present on the site (Everitt and Drawe 1993; Hatch and Pluhar 1993).

Because of the thin soils and grazing by livestock, the site vegetation is generally sparse, except for the cenizo and blackbrush acacia. Ground visibility ranges from approximately 50 to 70 percent.

\section{SITE DESCRIPTION}

Site 41VV1685 consists of an extensive lithic scatter including tested chert cobbles, flakes, thick bifaces, and projectile points. The site measures approxi- mately $560 \times 130 \mathrm{~m}$, or $72,800 \mathrm{~m}^{2}$. Because the site is so large, it was divided into four areas (designated Areas A, B, C, and D), each of which is a terrace lobe cut on both sides by an arroyo (Figure 5-8). The site appears to be limited to the high terrace and the first bench beneath it. A few artifacts were observed in the arroyos that cut into the high terrace, but these appear to have been displaced by erosion.

Area A includes the southwesternmost part of the site. It measures approximately $130 \times 110 \mathrm{~m}$ and is bounded on the south by the base property line and on the north by a large arroyo. Area B measures approximately $155 \times 130 \mathrm{~m}$. An arroyo separates Area $B$ from Area $C$, which measures approximately $120 \times 75 \mathrm{~m}$. Area D, the largest of the four areas, measures $120 \times 200 \mathrm{~m}$. The site datum is located in the west-central part of Area D. 
Features

No cultural features were observed at this site.

Dogleash-Unit Inventories

Nine dogleash-unit inventories were conducted at the site (Figure 5-8). The results of these inventories are listed in Tables 5-9 through 5-12. One unidentified, unfinished dart point fragment was found in Dogleash Unit \#2 in Area D.

Table 5-9. Dogleash-Unit Inventory for Prehistoric Site 41VV1685, Area A

\begin{tabular}{||l|c|c|c||}
\hline \multicolumn{1}{|c|}{ Artifact Type } & $\begin{array}{c}\text { Dogleash } \\
\text { Unit \#1 }\end{array}$ & $\begin{array}{c}\text { Dogleash } \\
\text { Unit \#2 }\end{array}$ & $\begin{array}{c}\text { Dogleash } \\
\text { Unit \#3 }\end{array}$ \\
\hline Primary flakes & 17 & 22 & 21 \\
\hline Secondary flakes & 24 & 32 & 65 \\
\hline Tertiary flakes & 7 & 7 & 22 \\
\hline Retouched flakes & 2 & 9 & 0 \\
\hline Unifaces (and fragments) & 0 & 0 & 0 \\
\hline Bifaces (and fragments) & 2 & 4 & 3 \\
\hline Projectile points (and fragments) & 0 & 0 & 0 \\
\hline Cores & 2 & 6 & 4 \\
\hline Tested cobbles & 2 & 4 & 10 \\
\hline Heat-spalled chert & 0 & 0 & 0 \\
\hline Thermally altered limestone & 0 & 0 & 0 \\
\hline Total & $\mathbf{5 6}$ & $\mathbf{8 4}$ & $\mathbf{1 2 5}$ \\
\hline
\end{tabular}

Table 5-10. Dogleash-Unit Inventory for Prehistoric Site 41VV1685, Area B

\begin{tabular}{|c|c|c|}
\hline Artifact Type & $\begin{array}{c}\text { Dogleash } \\
\text { Unit \#1 }\end{array}$ & $\begin{array}{c}\text { Dogleash } \\
\text { Unit \#2 }\end{array}$ \\
\hline Primary flakes & 15 & 19 \\
\hline Secondary flakes & 27 & 45 \\
\hline Tertiary flakes & 23 & 27 \\
\hline Retouched flakes & 16 & 5 \\
\hline Unifaces (and fragments) & 0 & 0 \\
\hline Bifaces (and fragments) & 1 & 0 \\
\hline Projectile points (and fragments) & 0 & 0 \\
\hline Cores & 2 & 7 \\
\hline Tested cobbles & 3 & 10 \\
\hline Heat-spalled chert & 1 & 0 \\
\hline Thermally altered limestone & 0 & 0 \\
\hline Total & 88 & 113 \\
\hline
\end{tabular}


Table 5-11. Dogleash-Unit Inventory for Prehistoric Site 41VV1685, Area C

\begin{tabular}{|c|c|c|}
\hline Artifact Type & $\begin{array}{c}\text { Dogleash } \\
\text { Unit \#1 }\end{array}$ & $\begin{array}{c}\text { Dogleash } \\
\text { Unit \#2 }\end{array}$ \\
\hline Primary flakes & 34 & 24 \\
\hline Secondary flakes & 56 & 50 \\
\hline Tertiary flakes & 24 & 11 \\
\hline Retouched flakes & 11 & 3 \\
\hline Unifaces (and fragments) & 1 & 0 \\
\hline Bifaces (and fragments) & 0 & 2 \\
\hline Projectile points (and fragments) & 0 & 0 \\
\hline Cores & 8 & 4 \\
\hline Tested cobbles & 8 & 3 \\
\hline Heat-spalled chert & 3 & 5 \\
\hline Thermally altered limestone & 0 & 1 \\
\hline Total & 145 & 103 \\
\hline
\end{tabular}

Table 5-12. Dogleash-Unit Inventory for Prehistoric Site 41VV1685, Area D

\begin{tabular}{|c|c|c|}
\hline Artifact Type & $\begin{array}{c}\text { Dogleash } \\
\text { Unit \#1 }\end{array}$ & $\begin{array}{c}\text { Dogleash } \\
\text { Unit } \# 2\end{array}$ \\
\hline Primary flakes & 56 & 7 \\
\hline Secondary flakes & 78 & 15 \\
\hline Tertiary flakes & 49 & 8 \\
\hline Retouched flakes & 7 & 1 \\
\hline Unifaces (and fragments) & 3 & 0 \\
\hline Bifaces (and fragments) & 3 & 0 \\
\hline Projectile points (and fragments) & 0 & 1 \\
\hline Cores & 7 & 0 \\
\hline Tested cobbles & 6 & 0 \\
\hline Heat-spalled chert & 40 & 0 \\
\hline Thermally altered limestone & 4 & 0 \\
\hline Total & 253 & 32 \\
\hline
\end{tabular}

Subsurface Testing

Nineteen shovel tests (STs 50-68) were excavated at site 41VV1685 (Figure 5-9). The shovel tests ranged from 1 to $50 \mathrm{~cm}$ in depth, depending on the depth of the underlying bedrock.
In Area A four shovel tests (STs 62-65) were dug. The sediments were silty loams containing 50 to 90 percent gravels and ranging in depth from 8 to $50 \mathrm{~cm}$ or more below the modern surface. Although artifacts were present on the ground surface, no subsurface artifacts were recovered from the shovel tests in Area A. 


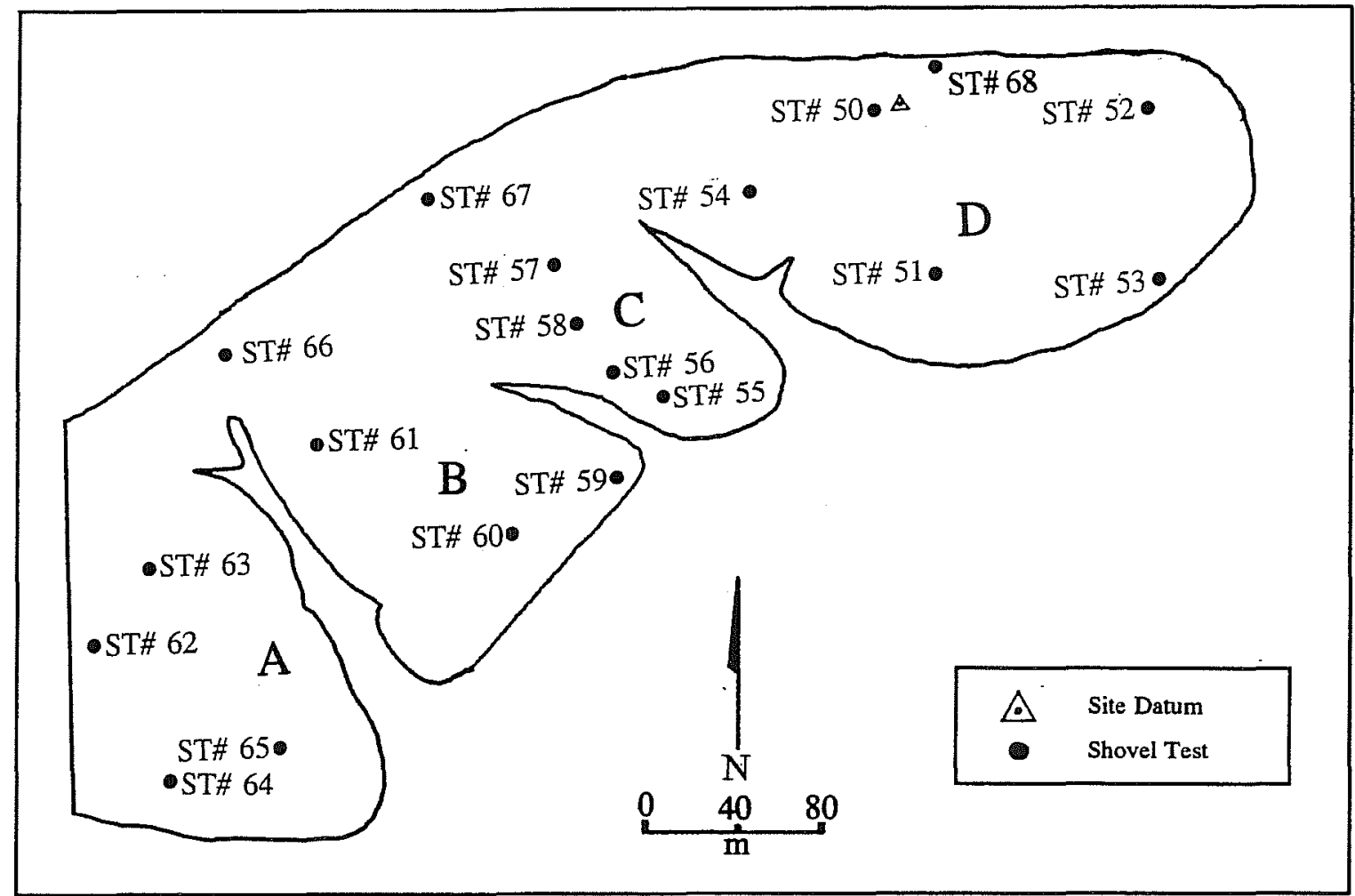

Figure 5-9. Shovel test locations, site 41VV1685.

Four shovel tests (STs 59-61 and 66) were excavated in Area B (Figure 5-9). The sediments were sandy clay loams containing gravels which comprised 5 to 85 percent of the volume; these sediments ranged from $8 \mathrm{~cm}$ to more than $50 \mathrm{~cm}$ in depths. Although numerous artifacts were visible on the surface, only one of the Area B shovel tests (ST 60) yielded subsurface artifacts, at a depth of 10 to $20 \mathrm{~cm}$ (Table 5-13).

In Area C five shovel tests (STs 55-58 and 67) were dug (Figure 5-9). The soils were sandy clay loams to silty loams containing gravel varying from between 25 and 80 percent by volume. The sediments were 25 $\mathrm{cm}$ to more than $50 \mathrm{~cm}$ in depth. In one Area $\mathrm{C}$ shovel test (ST 57), a chert flake was recovered from 25 to $30 \mathrm{~cm}$ below ground surface (Table 5-13).

Six shovel tests (STs 50-54 and 68) were excavated in Area D (Figure 5-9). The soils were sandy clays to sandy loams, and ranged in depth from $1 \mathrm{~cm}$ to more than $50 \mathrm{~cm}$ below the modern ground surface. ST 50 yielded a chert chunk at a depth of $2 \mathrm{~cm}$.

Table 5-13. Shovel Tests and Levels which Produced Artifacts on Site 41VV1685

\begin{tabular}{|c|c|c|c|c|c|}
\hline $\begin{array}{c}\text { Shovel Test/ } \\
\text { Area }\end{array}$ & $\begin{array}{c}0 \text { to } 10 \\
\mathrm{~cm}\end{array}$ & $\begin{array}{c}10 \text { to } 20 \\
\mathbf{c m}\end{array}$ & $\begin{array}{c}20 \text { to } 30 \\
\mathbf{c m}\end{array}$ & $\begin{array}{c}30 \text { to } 40 \\
\mathbf{c m}\end{array}$ & $\begin{array}{c}40 \text { to } 50 \\
\mathbf{c m}\end{array}$ \\
\hline ST 50/D & $\mathrm{X}$ & & & & \\
\hline ST 57/C & & & $\mathrm{X}$ & & \\
\hline ST 60/B & & $\mathrm{X}$ & & & \\
\hline
\end{tabular}




\section{DISCUSSION}

Site 41VV1685 is an extensive creek-associated lithic scatter, located on a high terrace overlooking Sacatosa Creek. Numerous chert cobbles and pebbles are present on the site surface. The results of the dogleash-unit inventories indicate that Areas A, B, and $\mathrm{C}$ contained numerous tested cobbles, cores, and a predominance of primary and secondary flakes; additionally, a number of thick bifaces were observed in Area A. The densest concentration of these lithics is in Area A, with the density decreasing eastward across the site toward Area D. Area D, in contrast to Areas $A-C$, has greater amounts of tertiary flakes and also includes formal tools, consisting of worked flakes, unifaces, bifaces, and one unfinished projectile point fragment; thermally altered rock was also observed in Area D, but not in the other areas.
This site is one in a cluster of sites within the Sacatosa Creek drainage and has the potential to contribute substantial data to the understanding of past human adaptations in this area of the Lower Pecos. Site 41VV1685 is recommended as eligible for nomination to the National Register of Historic Places under Criterion D. In order to develop a data recovery plan, additional testing would be required.

\section{VV1686}

Site 41VV1686 (Figure 5-10) is a prehistoric site located along the low-lying eastern bank of Sacatosa Creek. This area is used by a local landowner for grazing livestock (goats, cattle, and horses). Some recreational activities also take place along the creek. Site 41VV1686 is the southernmost of a series of six sites extending along the bank of Sacatosa Creek.

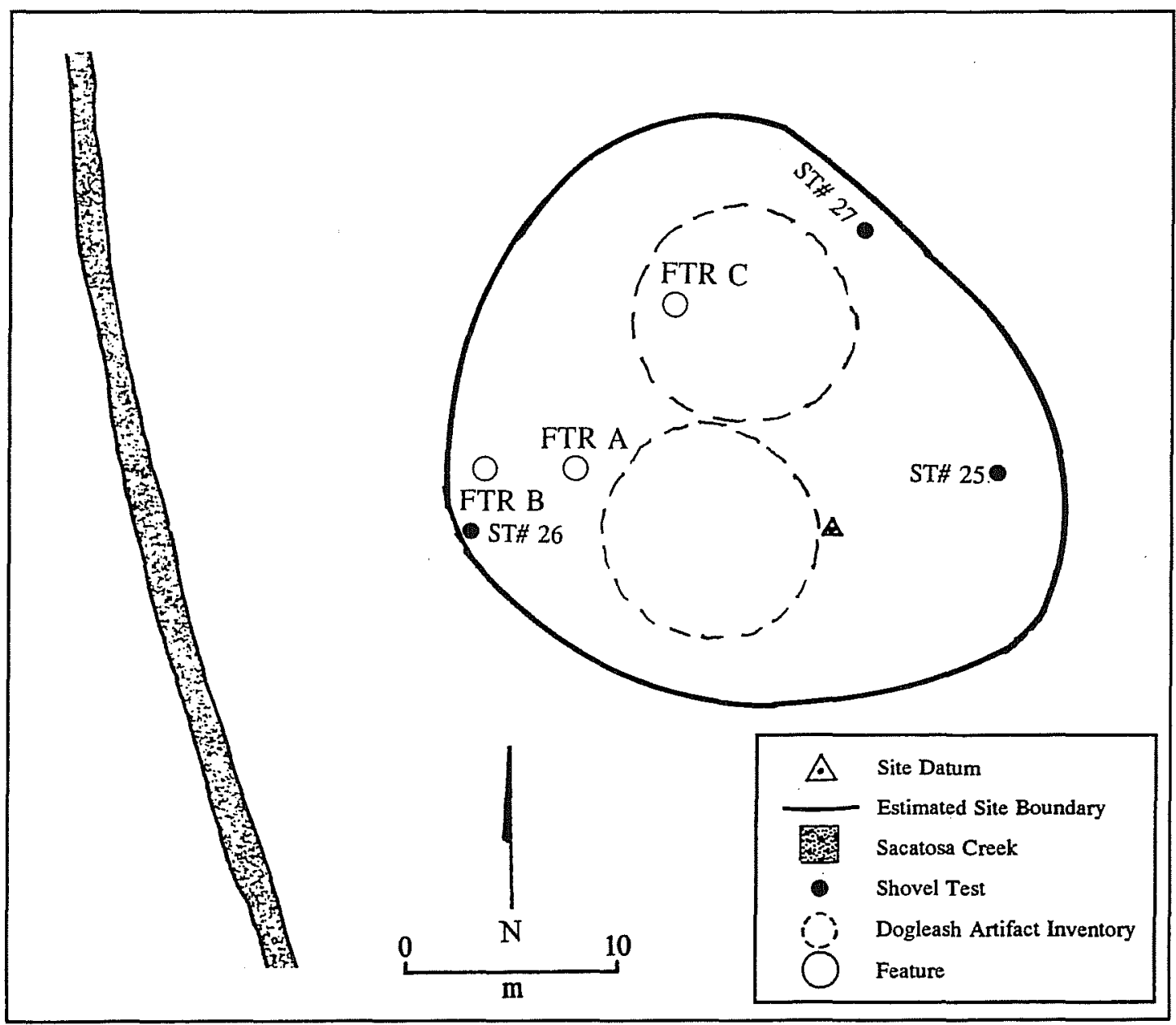

Figure 5-10. Site map, 41 VV1686. 


\section{SITE SETTING}

Topography

The site is situated on a low, fairly level first terrace of Sacatosa Creek. The elevation at the site datum is approximately $312 \mathrm{~m}(1,020 \mathrm{ft})$ amsl. The low elevation above the creek of this terrace probably results in frequent flooding of the site, although the apparently intact features at this and the other six sites along the creeks suggest that such flooding is of low velocity. Grazing by livestock has removed many of the grass species at the site, making the potential damage to the site from flooding more pronounced.

\section{Soils}

This small site is located at the juncture of three soil series. Along the western site boundary, toward the creek, are alluvial clays of the Pintas series, which are deep clays on the floodplains of small perennial streams (Golden et al. 1982:35-36, Map 55). The southern part of the site has soils of the Coahuila series, consisting of gently sloping clay loams on old stream terraces and low uplands (Golden et al. 1982:20-21, Map 55). The northeastern part of the site has soils of the Val Verde series, which are gently sloping silty clay loams on valley fills on uplands (Golden et al. 1982:43, Map 55).

\section{Vegetation}

Site 41VV1686 is on the first terrace above Sacatosa Creek and the vegetation on the site shows the results of grazing by livestock. Mesquite trees, some of which are quite large, shade roughly half the site. Woody plants such as cenizo and blackbrush acacia, and cacti such as Texas prickly pear and tasajillo also are present (Everitt and Drawe 1993; Hatch and Pluhar 1993). A few grasses also occur in this area, but they are closely cropped and were not identified. Because of grazing many areas of the site are barren of vegetation. Much of the site has good ground surface visibility, from 60 to 80 percent.

\section{SITE DESCRIPTION}

Site 41VV1686 is a prehistoric lithic scatter measuring approximately $30 \times 28 \mathrm{~m}$, or $840 \mathrm{~m}^{2}$ in area (Figure 5-10). The lithic scatter at the site includes chert debitage, a core fragment, and bifaces. Additionally, several concentrations of thermally altered stones which may represent hearth remnants are present (Figure 5-11). Most of the artifacts found on the site surface are eroding out of the clay and clay loams in areas barren of vegetation. These barren areas range in size from 0.5 to $5 \mathrm{~m}$ in diameter and probably represent places where favored grasses have been stripped away by roaming livestock.

\section{Features}

Three concentrations (designated Features A, B, and C) of partially buried, thermally altered stones that may be hearth remnants were found. These stones consist of both rounded river cobbles and fragments or slabs of the highly fossiliferous limestone, commonly found along the creek, which turns from a gold-tan color to a brick-red color when burned.

Feature $A$ is located $13 \mathrm{~m}$ west of the site datum (Figure 5-10). It consists of approximately 25 partially buried, thermally altered pieces of limestone. These stones form a rough circle approximately $1 \mathrm{~m}$ in diameter (Figure 5-11).

Feature B is a concentration of thermally altered stones located approximately $16.6 \mathrm{~m}$ west of the site datum, and approximately $3.5 \mathrm{~m}$ west of Feature A (Figure 5-10). Feature B consists of 19 pieces of thermally altered limestone forming a rough circle approximately $1 \mathrm{~m}$ in diameter. The stones are situated in a slight depression.

Feature $\mathrm{C}$ is located $13.7 \mathrm{~m}$ northwest of the site datum (Figure 5-10). It consists of a roughly circular concentration, slightly less than $1 \mathrm{~m}$ in diameter, of 30 partially buried, thermally altered pieces of limestone (Figure 5-11).

\section{Dogleash-Unit Inventories}

Two dogleash-unit inventories were conducted at site 41 VV1686 (Figure 5-10). The results of these inventories are shown in Table 5-14.

\section{Subsurface Testing}

Three shovel tests (STs 25-27) were excavated at site 41VV1686. All were excavated to a depth of $50 \mathrm{~cm}$ below the modern ground surface. ST 25 was located $8 \mathrm{~m}$ southeast of the site datum (Figure 5-10). The sediments were brownish yellow sandy silt with about 40 percent pea-sized gravels, which decreased to approximately 20 percent by a depth of $20 \mathrm{~cm}$. No artifacts were recovered from this shovel test. 


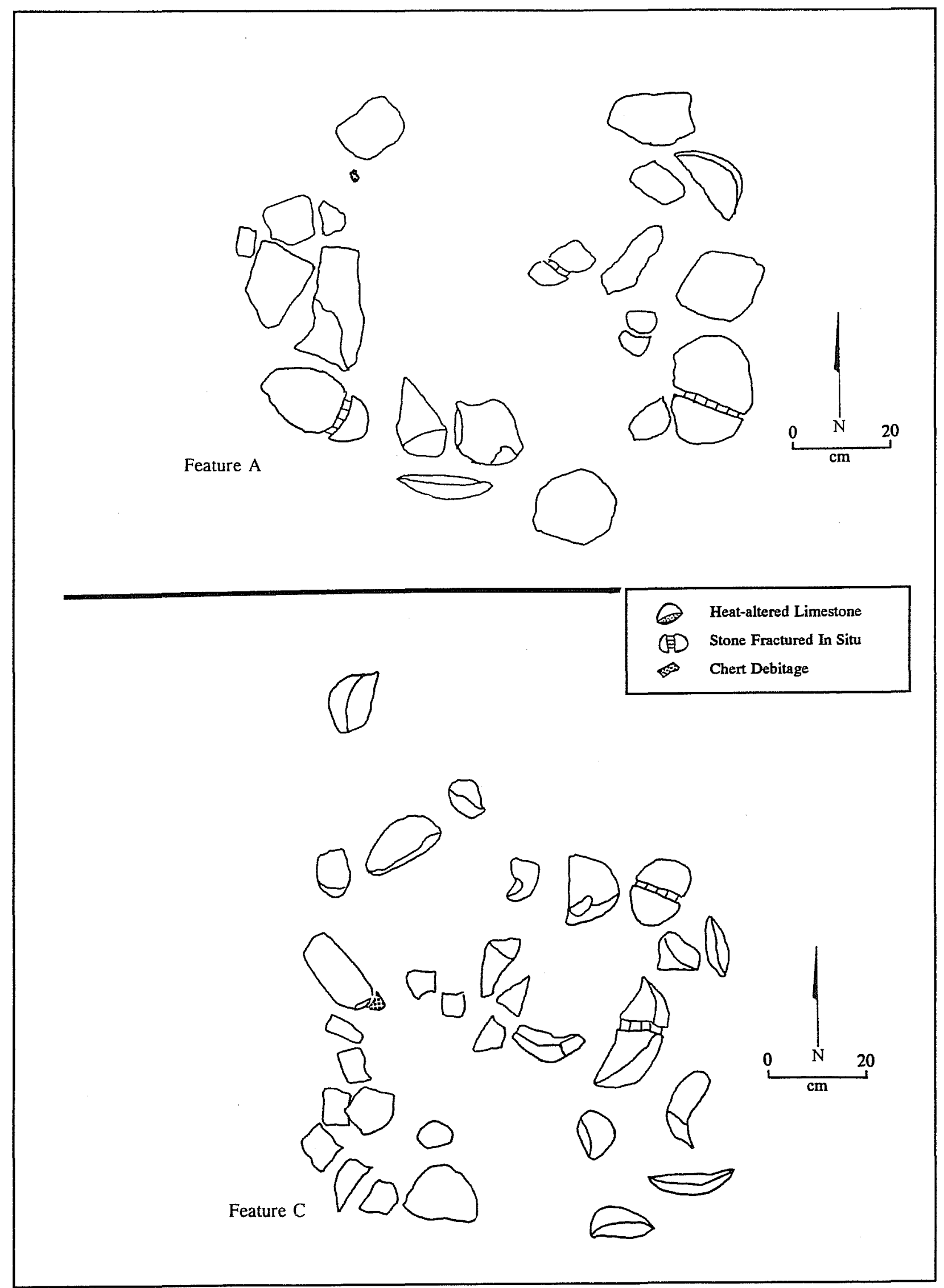

Figure 5-11. Features $A$ and $C$, site $41 \mathrm{VV} 1686$. 
Table 5-14. Dogleash-Unit Inventory for Site 41VV1686

\begin{tabular}{|c|c|c|}
\hline Artifact Type & $\begin{array}{c}\text { Dogleash } \\
\text { Unit \#1 }\end{array}$ & $\begin{array}{c}\text { Dogleash } \\
\text { Unit \#2 }\end{array}$ \\
\hline Primary flakes & 2 & 1 \\
\hline Secondary flakes & 8 & 10 \\
\hline Tertiary flakes & 15 & 6 \\
\hline Retouched flakes & 0 & 0 \\
\hline Unifaces (and fragments) & 0 & 0 \\
\hline Bifaces (and fragments) & 4 & 0 \\
\hline Projectile points (and fragments) & 0 & 0 \\
\hline Cores & 0 & 1 \\
\hline Tested cobbles & 0 & 0 \\
\hline Heat-spalled chert & 0 & 0 \\
\hline Thermally altered limestone & 23 & 18 \\
\hline Total & 52 & 36 \\
\hline
\end{tabular}

ST 26 was located $1 \mathrm{~m}$ west of Feature B (Figure 5-10). The sediments, from a depth of 0 to $30 \mathrm{~cm}$, were a grayish tan sandy silt with approximately 40 to 50 percent pea-sized gravels. Between 30 and 50 $\mathrm{cm}$ below the ground surface, the gravels constituted only about 10 percent of the volume and were mixed with much caliche. A core fragment was recovered from the 0 to $10 \mathrm{~cm}$ level and a tertiary flake was from the 20 to $30 \mathrm{~cm}$ level of this shovel test (Table 5-15).

The third shovel test (ST 27) was located $14 \mathrm{~m}$ south of the site datum (Figure 5-10). The sediments, from a depth of 0 to $20 \mathrm{~cm}$, were grayish tan sandy silt with approximately 50 percent pea-sized gravel and some larger limestone rocks ( 3 to $5 \mathrm{~cm}$ in diameter). From 20 to $50 \mathrm{~cm}$ in depth, the sediment had approximately 30 percent gravels and a caliche/silt mix, the latter increased in amount with depth. A modified secondary chert flake was recovered from the 0 to $10 \mathrm{~cm}$ level of this shovel test (Table 5-15).

\section{DISCUSSION}

The results of the dogleash-unit inventories at this site indicate a predominance of secondary and tertiary flakes and the presence of a core and bifaces. Three hearth features, as well as other, poorly defined concentrations of burned rock, are present. The shovel tests indicate subsurface cultural deposits to a depth of $30 \mathrm{~cm}$ below the modern ground surface. Although the site is small, the presence of features, some evidence for subsurface deposits, and

Table 5-15. Shovel Tests and Levels which Produced Artifacts on Site 41 VV1686

\begin{tabular}{||c||c|c|c|c|c|}
\hline Shovel Tests & $\begin{array}{c}0 \text { to } 10 \\
\mathrm{~cm}\end{array}$ & $\begin{array}{c}10 \text { to } 20 \\
\mathrm{~cm}\end{array}$ & $\begin{array}{c}20 \text { to } 30 \\
\mathrm{~cm}\end{array}$ & $\begin{array}{c}30 \text { to } 40 \\
\mathrm{~cm}\end{array}$ & $\begin{array}{c}40 \text { to } 50 \\
\mathbf{c m}\end{array}$ \\
\hline ST 26 & $\mathrm{X}$ & & $\mathrm{X}$ & & \\
\hline ST 27 & $\mathrm{X}$ & & & & \\
\hline
\end{tabular}


the overall artifact context make this site significant. This site is one in a cluster of sites within the Sacatosa Creek drainage and has the potential to contribute substantial data to the understanding of past human adaptations in this area of the Lower Pecos. Site 41VV1686 is recommended as eligible for nomination to the National Register of Historic Places under Criterion D. In order to develop a data recovery plan, additional testing would be required.

\section{VV1687}

Site 41VV1687 (Figure 5-12) is a small prehistoric lithic scatter eroding out of the T1 terrace along Sacatosa Creek. This area is currently is used by a local landowner to graze livestock. Additionally, some recreational activities take place along the creek. Site 41VV1687 is located approximately $48 \mathrm{~m}$ north of site 41VV1686.

\section{SITE SETTING}

\section{Topography}

The site lies very close to the present course of Sacatosa Creek; the site datum is located only $20 \mathrm{~m}$ from the edge of the creek. The ground surface at the site slopes slightly downward to the west, toward the creek. A low bench, perhaps 10 to $15 \mathrm{~cm}$ in elevation, extends across the central part of the site.

A small, eroded area approximately $2 \mathrm{~m}$ in width is located along this bench; more than 90 percent of the surface artifacts were found within this area (Figure 5-12).

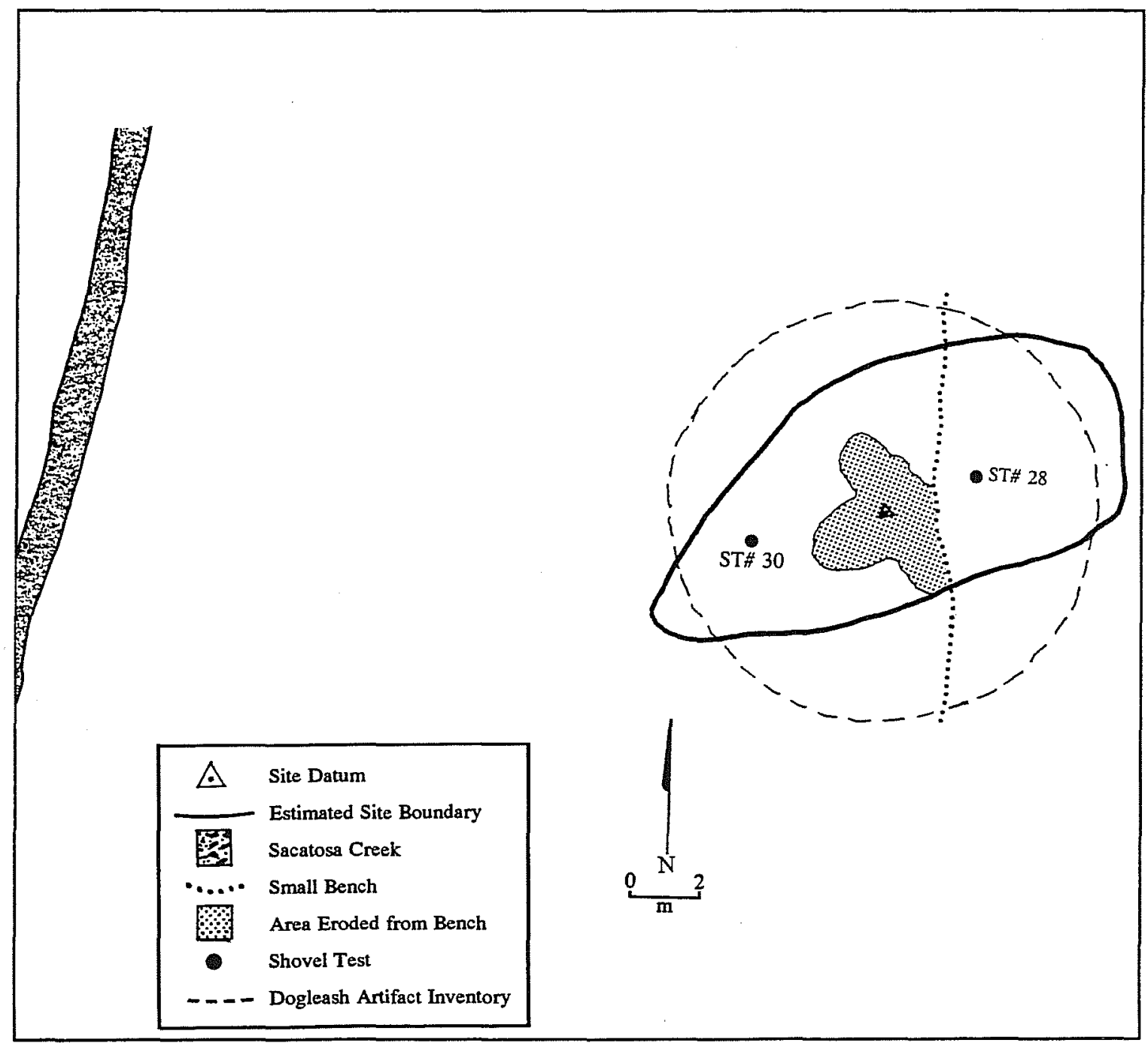

Figure 5-12. Site map, 41 VV1687. 
Soils

Soils at site 41 VV1687 are of the Pintas series (Golden et al. 1982:35-36, Map 55). These are deep alluvial clays on the flood plains of small perennial streams.

\section{Vegetation}

Site 41VV1687 is creek-associated and is on the T1 terrace. Although the position of the site near water would normally ensure heavy vegetation, use of this area for livestock grazing has thinned the plants. A few closely cropped grasses are present but the dominant plant species on the site is mesquite, several large specimens of which shade the site. Blackbrush acacia and Texas prickly pear are also present (Everitt and Drawe 1993; Hatch and Pluhar 1993).

The shade from the trees and grazing by livestock has resulted in little to no ground cover for the site. Only above the bench are any shrubs present. Grasses are sparse and do little to hide the ground surface; hence, visibility was good, from 70 to 100 percent.

\section{SITE DESCRIPTION}

Site $41 \mathrm{VV} 1687$ measures approximately $6 \times 10 \mathrm{~m}$, or $60 \mathrm{~m}^{2}$ in area (Figure 5-12). It includes a small scatter of chert flakes, including a uniface and thermally altered limestone. The majority of cultural material appears to have eroded from the low bank which cuts across the site.

Features

Several large and numerous small pieces of thermally altered fossiliferous and non-fossiliferous limestone were present, indicating features are present at this site.

Dogleash-Unit Inventories

Because of the small size of the site, only one dogleash-unit artifact inventory was conducted (Figure 5-12). The results are presented in Table 5-16.

Subsurface Testing

Two shovel tests (STs 28 and 30) were excavated at site 41VV1687, both of which were $50 \mathrm{~cm}$ in depth. The first shovel test (ST 28) was located $2.5 \mathrm{~m}$ east

Table 5-16. Dogleash-Unit Inventory for Site 41VV1687

\begin{tabular}{|l|c|}
\hline \multicolumn{1}{|c|}{ Artifact Type } & $\begin{array}{c}\text { Dogleash } \\
\text { Unit \#1 }\end{array}$ \\
\hline Primary flakes & 4 \\
\hline Secondary flakes & 19 \\
\hline Tertiary flakes & 9 \\
\hline Retouched flakes & 2 \\
\hline Unifaces (and fragments) & 1 \\
\hline Bifaces (and fragments) & 0 \\
\hline Projectile points (and fragments) & 0 \\
\hline Cores & 0 \\
\hline Tested cobbles & 0 \\
\hline Heat-spalled chert & 0 \\
\hline Thermally altered limestone & 52 \\
\hline & $\mathbf{8 7}$ \\
\hline
\end{tabular}


of the site datum, above the edge of the small bench (Figure 5-12). The sediments, from the modern ground surface to $50 \mathrm{~cm}$ in depth, were a grayish brown clay loam with very little (5 percent) pea- and marble-sized gravel. Secondary and tertiary chert flakes were recovered from the $0-$ to- $10-\mathrm{cm}$ and the 10-to-20-cm levels (Table 5-17).

ST 30 was located $3 \mathrm{~m}$ west of the site datum (Figure 5-12). From the surface to $50 \mathrm{~cm}$ below the modern ground surface the sediments were light brown clay loam with 10 to 20 percent marble-sized gravel. A core fragment and 5 pieces of thermally altered limestone ( 3 to $5 \mathrm{~cm}$ in diameter) were recovered from the $0-$ to- $10-\mathrm{cm}$ level of this shovel test (Table 5-17).

\section{DISCUSSION}

The dogleash-unit inventory indicates a predominance of secondary chert flakes with lesser amounts of primary and tertiary flakes, and the presence of a core, a uniface, and numerous pieces of thermally altered limestone on the site surface. The shovel test results indicate the presence of subsurface cultural material to a depth of $20 \mathrm{~cm}$ below the modern ground surface; however, additional parts of the site could remain buried further beneath the low creek bank.

This site is one in a cluster of sites within the Sacatosa Creek drainage and has the potential to contribute substantial data to the understanding of past human adaptations in this area of the Lower Pecos. Site 41VV1687 is recommended as eligible for nomination to the National Register of Historic Places under Criterion D. In order to develop a data recovery plan, additional testing would be required.

\section{VV1688}

Site 41VV1688 (Figure 5-13) lies along the edge of Sacatosa Creek. The area is used by a local landowner for grazing goats, cattle, and horses. Some recreational activities also take place along the creek.

\section{SITE SETTING}

\section{Topography}

The site is situated on the T1 terrace above Sacatosa Creek. It extends from the creek bank, across the terrace, and ends where the ground surface begins to slope upward more sharply toward a ridge east of the site. Most of the site is nearly level, with the ground surface sloping gently toward the creek. The site elevation is $312 \mathrm{~m}(1,020 \mathrm{ft})$ amsl.

\section{Soils}

The soils on the site are from two series, the Pintas series-deep clays on the floodplains of small perennial streams-and the Val Verde series-gently sloping silty clay loams on valley fills on uplands. The Pintas soils lie along the edge of the creek, in the western third of the site. The Val Verde soils extend over the eastern two-thirds of the site (Golden et al. 1982:35-36, 43, Map 55).

\section{Vegetation}

Site 41 VV1688 is creek-associated. The vegetation on the site has been strongly affected by the grazing of livestock. Large mesquite trees shade much of the site, especially the western third. While some grasses are present, most are severely cropped and were not identified. The site also contains blackbrush acacia and Texas prickly pear. On the eastern edge of the site, cenizo becomes common (Everitt and Drawe 1993; Hatch and Pluhar 1993). Grazing apparently

Table 5-17. Shovel Tests and Levels which Produced Artifacts on Site 41VV1687

\begin{tabular}{|c|c|c|c|c|c|}
\hline Shovel Tests & $\begin{array}{c}0 \text { to } 10 \\
\text { cm }\end{array}$ & $\begin{array}{c}10 \text { to } 20 \\
\text { cm }\end{array}$ & $\begin{array}{c}20 \text { to } 30 \\
\text { cm }\end{array}$ & $\begin{array}{c}30 \text { to } 40 \\
\text { cm }\end{array}$ & $\begin{array}{c}40 \text { to } 50 \\
\text { cm }\end{array}$ \\
\hline ST 28 & $X$ & $X$ & & & \\
\hline ST 30 & $X$ & & & & \\
\hline
\end{tabular}




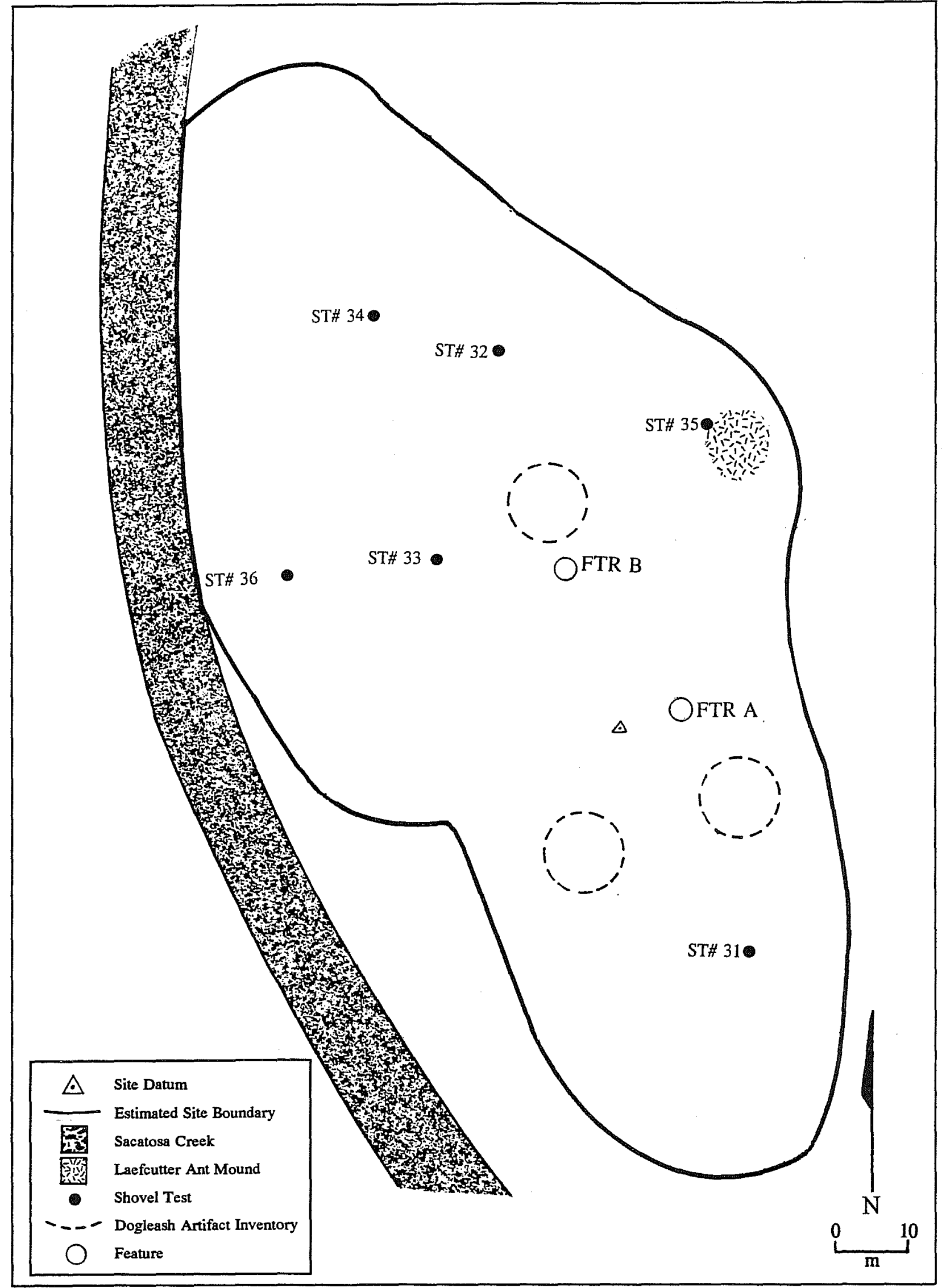

Figure 5-13. Site map, 41VV1688. 
caused several areas within the site to be barren of vegetation. These bare areas measure between $0.5 \mathrm{~m}$ and $5 \mathrm{~m}$ in length, and are more common away from the creek.

\section{SITE DESCRIPTION}

Site 41VV1688 measures approximately $80 \mathrm{x}$ $160 \mathrm{~m}$, or roughly $12,800 \mathrm{~m}^{2}$ in area (Figure 5-13): The eastern boundary of the site is generally marked by a change in dominant vegetation from mesquite trees to cenizo.

Cultural material observed at the site includes two projectile points: a Middle Archaic Kinneylike point; a Late Prehistoric Ensor point fragment; and a small, shoulderless, lanceolate unidentified point. Bifacial tools, core tools, and large numbers of chert flakes are thinly scattered across the site. These chert objects were largely observed in areas barren of vegetation where erosion was evident.

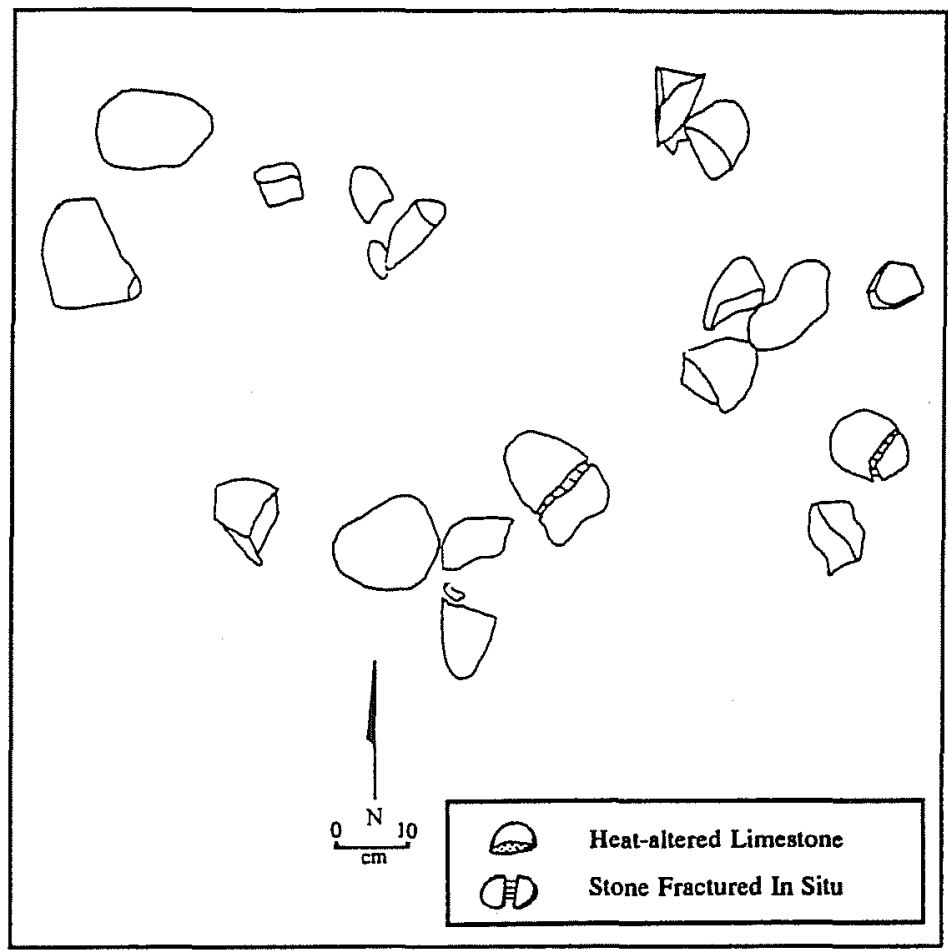

Figure 5-14. Feature A, site 41VVI688.

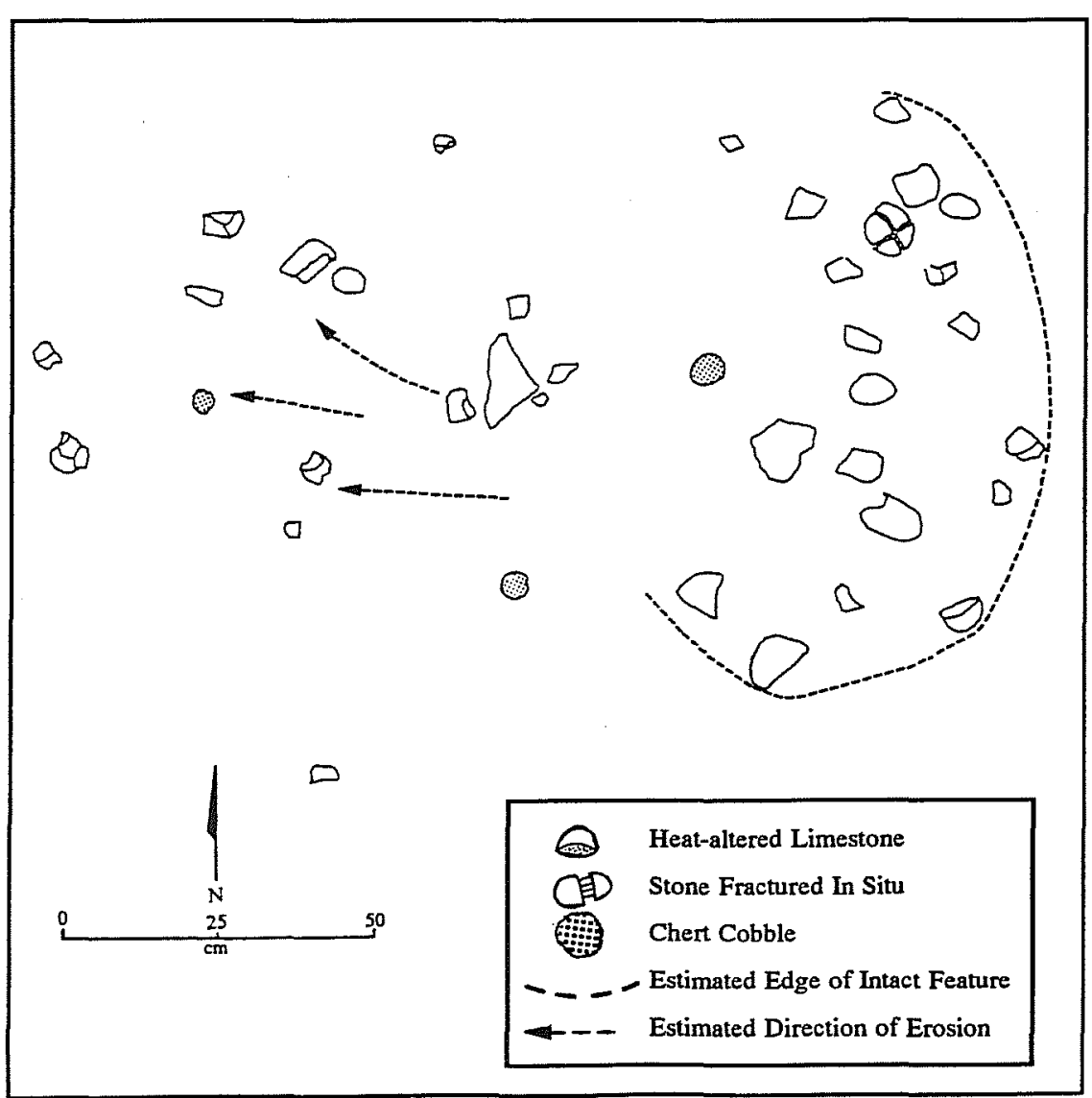

Figure 5-15. Feature B, site 41VV1688.
Features

Two concentrations of thermally altered rock (designated Features $\mathrm{A}$ and $B$ ), perhaps representing hearth remnants, were observed at site 41VV1688. These features consist of both smooth river cobbles and the highly fossiliferous limestone slabs, commonly occurring in this area, which turn from a gold-tan color to a brick red color when heated.

Feature A is a roughly oval-shaped concentration of 20 partially buried, thermally altered pieces of limestone (Figure 5-14). Feature B designates a concentration of 22 partially buried, thermally altered limestone pieces (Figure 5-15) in a roughly oval-shape. Extending westward from this oval-shaped concentration are 17 pieces of thermally altered limestone which appear to be a disturbed portion of Feature B. 
Dogleash-Unit Inventories

Three dogleash-unit inventories were conducted at site 41VV1688 (Figure 5-13). Results of these inventories are presented in Table 5-18.

Subsurface Testing

Six shovel tests (STs 31-36) were dug on site 41VV1688 (Figure 5-13). A depth of $50 \mathrm{~cm}$ below the modern ground surface was reached in all six shovel tests.

ST 31, in the southern part of the site (Figure 5-13), showed a uniform grayish brown sandy silt with 10 to 25 percent pea- to marble-sized limestone gravel, present from the modern ground surface to a depth of $50 \mathrm{~cm}$. No cultural material was recovered from this shovel test.

Two shovel tests (STs 32 and 34), situated in the northern part of the site (Figure 5-13), also had uniform grayish brown sandy silt to a depth of $50 \mathrm{~cm}$. In ST 32 an unmodified tertiary flake, two trimmed tertiary chert flakes, and a piece of thermally altered limestone were recovered from the 0 -to- $10-\mathrm{cm}$ level (Table 5-19).

Three shovel tests (STs 33, 35, and 36) were excavated in the central part of the site (Figure 5-13). The easternmost of these shovel tests (ST 35) contained light brown sandy loam with 70 to 90 percent golf ball- to fist-sized limestone gravels. No cultural material was recovered. ST 33 had uniform grayish brown sandy silt with 5 to 10 percent peasized gravels to a depth of $50 \mathrm{~cm}$. A chert chunk and a tertiary flake were recovered from the 0 -to- $10-\mathrm{cm}$ level of this shovel test. The westernmost shovel test (ST 36) also showed a uniform profile of grayish brown sandy silt with some ( 10 to 20 percent) pea- to golf ball-sized gravels to a depth of $50 \mathrm{~cm}$. One small chert chunk was recovered from the 20-to-30$\mathrm{cm}$ level.

Table 5-18. Dogleash-Unit Inventory for Site 41VV1688

\begin{tabular}{|l|c|c|c|}
\hline \multicolumn{1}{|c|}{ Artifact Type } & $\begin{array}{c}\text { Dogleash } \\
\text { Unit \#1 }\end{array}$ & $\begin{array}{c}\text { Dogleash } \\
\text { Unit \#2 }\end{array}$ & $\begin{array}{c}\text { Dogleash } \\
\text { Unit \#3 }\end{array}$ \\
\hline Primary flakes & 0 & 0 & 0 \\
\hline Secondary flakes & 6 & 1 & 3 \\
\hline Tertiary flakes & 9 & 3 & 1 \\
\hline Retouched flakes & 0 & 0 & 0 \\
\hline Unifaces (and fragments) & 0 & 0 & 0 \\
\hline Bifaces (and fragments) & 1 & 0 & 0 \\
\hline Projectile points (and fragments) & 2 & 1 & 0 \\
\hline Cores & 0 & 0 & 0 \\
\hline Tested cobbles & 0 & 0 & 0 \\
\hline Heat-spalled chert & 0 & 0 & 0 \\
\hline Thermally altered limestone & 0 & 0 & 0 \\
\hline & $\mathbf{1 8}$ & $\mathbf{5}$ & $\mathbf{4}$ \\
\hline
\end{tabular}


Table 5-19. Shovel Tests and Levels which Produced Artifacts on Site 41VV1688

\begin{tabular}{|c||c|c|c|c|c|}
\hline Shovel Tests & $\begin{array}{c}0 \text { to } 10 \\
\mathbf{c m}\end{array}$ & $\begin{array}{c}10 \text { to } 20 \\
\mathbf{c m}\end{array}$ & $\begin{array}{c}20 \text { to } 30 \\
\mathbf{c m}\end{array}$ & $\begin{array}{c}30 \text { to } 40 \\
\mathbf{c m}\end{array}$ & $\begin{array}{c}40 \text { to } 50 \\
\mathbf{c m}\end{array}$ \\
\hline ST 32 & $\mathrm{X}$ & & & & \\
\hline ST 33 & $\mathrm{X}$ & & & & \\
\hline ST 36 & & & $\mathrm{X}$ & & \\
\hline
\end{tabular}

\section{DISCUSSION}

The results of the dogleash-unit inventory indicate a predominance of secondary and tertiary chert flakes, with no primary flakes. A thin ovate biface and a small, shoulderless lanceolate dart point were also present in the dogleash units. Two diagnostic dart points suggest the site contains Middle and Late Archaic components. The shovel test results indicate shallow cultural deposits, extending only perhaps to a maximum depth of $10 \mathrm{~cm}$ below the modern ground surface. Generally, this site appears to be an occupation site at which resharpening or final thinning of lithics occurred.

This site is one in a cluster of sites within the Sacatosa Creek drainage and has the potential to contribute substantial data to the understanding of past human adaptations in this area of the Lower Pecos. Site 41VV1688 is recommended as eligible for nomination to the National Register of Historic Places under Criterion D. In order to develop a data recovery plan, additional testing would be required.

\section{VV1689}

Site 41VV1689 (Figure 5-16) is a lithic scatter with two areas in which most of the lithics are concentrated. It is the northernmost site of a series of six sites located adjacent to Sacatosa Creek. The area is used by a local landowner for grazing livestock. Recreational activities also occur along the creek.

\section{SITE SETTING}

\section{Topography}

The site is located near Sacatosa Creek and extends eastward across the first terrace to where the land begins to slope upward toward a ridge to the southeast. The site slopes gently downward toward the creek. Cutting through the site is an arroyo varying in size from $1 \mathrm{~m}$ wide and $0.2 \mathrm{~m}$ deep to $5 \mathrm{~m}$ wide and $1 \mathrm{~m}$ deep. Dirt roads cut through the western and eastern part of the site. The elevation at the site datum is approximately $312 \mathrm{~m}(1,020 \mathrm{ft})$ amsl.

Soils

The soils on site 41 VV1689 are from two series. Most of the site lies on soils of the Pintas clay series, consisting of deep alluvial clays on the flood plains of small perennial streams (Golden et al. 1982:35-36, Map 55). The eastern quarter of the site has soils of the Val Verde series, which are gently sloping silty clay loams on valley fills on uplands (Golden et al. 1982:43, Map 55).

\section{Vegetation}

Site 41VV1689 is creek-associated. Vegetation on the site shows the effects of grazing by livestock. Large mesquite trees heavily shade the western half of the site, but this species is much smaller and more sparsely present in the eastern half, where cenizo and blackbrush acacia dominate. The few grasses present on the site are closely cropped and were not identified (Everitt and Drawe 1993; Hatch and Pluhar 1993). 


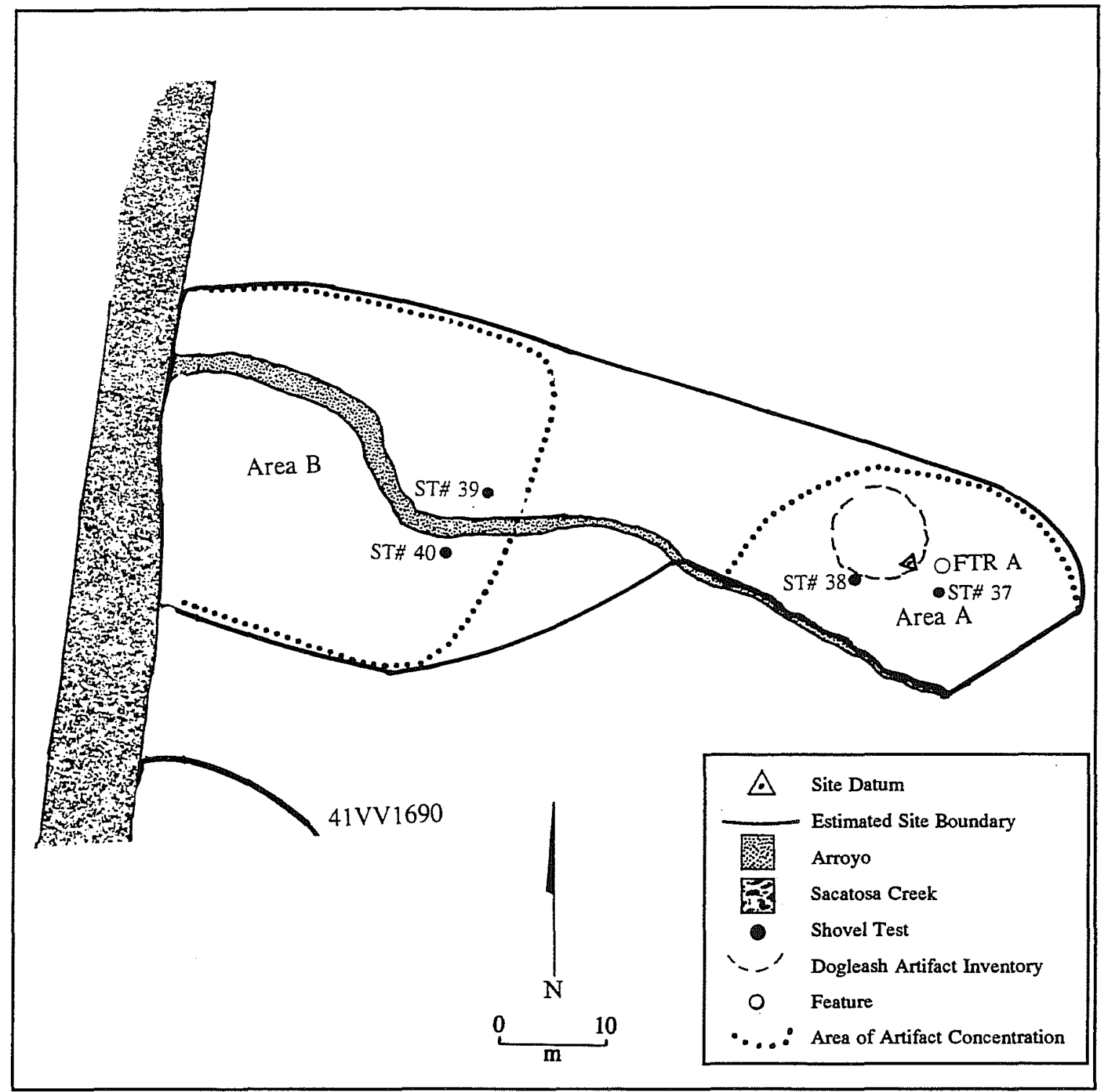

Figure 5-16. Site map, 41VV1689.

\section{SITE DESCRIPTION}

41VV1689 is a prehistoric site with two lithic concentrations, designated Areas A and B (Figure 5-16). The site measures approximately $105 \mathrm{~m}$ east-west. The eastern part of the site (Area A) is approximately $25 \mathrm{~m}$ wide, while the western part of the site (Area B) is approximately $40 \mathrm{~m}$ wide. The site boundaries enclose an approximately $2,800 \mathrm{~m}^{2}$ area. An arroyo cuts through the site, forming the southern edge of Area A, but cutting through the middle of Area B. Lithic density in both areas is very low. Artifacts observed include a core, a uniface tool, and a few chert flakes. Additionally, a heavily reworked Bandy/Martindale (8900 to 5500 B.P.) dart point fragment was collected.

\section{Features}

A roughly circular concentration of thermally altered limestone cobbles, designated Feature A, was located near the eastern edge of the site in Area A (Figure 5-16). Much of this feature, a possible hearth remnant, was buried.

At least two other concentration of thermally altered limestone were found which, although in eroded situations, may have been the remains of disturbed hearths. Both of these concentrations were in Area B, south of the arroyo (Figure 5-16). 
Dogleash-Unit Inventories

A single dogleash-unit artifact inventory was conducted on this site (Figure 5-16) because of the paucity of the lithic scatter. The results of the inventory are listed in Table 5-20.

Subsurface Testing

Four shovel tests (STs 37-40) were excavated to a depth of $50 \mathrm{~cm}$ below the modern ground surface. STs 37 and 38 were located in Area A, STs 39 and 40 in Area B (Figure 5-16). The two shovel tests in Area A showed a uniform medium brown sandy silt from the ground surface to a depth of $50 \mathrm{~cm}$. Six large (greater than $10-\mathrm{cm}$ diameter) limestone cobbles were recovered from the uppermost $10 \mathrm{~cm}$ of ST 37, located approximately $1.5 \mathrm{~m}$ south of Feature A. Some of these cobbles appeared thermally altered. No large rocks were present below a depth of $10 \mathrm{~cm}$, but a chert core fragment was recovered from a depth of 10 to $20 \mathrm{~cm}$ (Table 5-21).

The two shovel tests in Area B showed a uniform light brown sandy silt to a depth of $50 \mathrm{~cm}$. No cultural material was recovered from these shovel tests.

Table 5-20. Dogleash-Unit Inventory for Prehistoric Site 41VV1689

\begin{tabular}{|c|c|}
\hline Artifact Type & $\begin{array}{c}\text { Dogleash } \\
\text { Unit \#1 }\end{array}$ \\
\hline Primary flakes & 0 \\
\hline Secondary flakes & 3 \\
\hline Tertiary flakes & 1 \\
\hline Retouched flakes & 0 \\
\hline Unifaces (and fragments) & 0 \\
\hline Bifaces (and fragments) & 0 \\
\hline Projectile points (and fragments) & 0 \\
\hline Cores & 0 \\
\hline Tested cobbles & 0 \\
\hline Heat-spalled chert & 0 \\
\hline Thermally altered limestone & 4 \\
\hline Total & 8 \\
\hline
\end{tabular}

Table 5-21. Shovel Tests and Levels which Produced Artifacts on Site 41 VV1689

\begin{tabular}{|c|c|c|c|c|c|}
\hline Shovel Tests & $\begin{array}{c}0 \text { to } 10 \\
\mathrm{~cm}\end{array}$ & $\begin{array}{c}10 \text { to } 20 \\
\mathrm{~cm}\end{array}$ & $\begin{array}{c}20 \text { to } 30 \\
\mathrm{~cm}\end{array}$ & $\begin{array}{c}30 \text { to } 40 \\
\mathrm{~cm}\end{array}$ & $\begin{array}{c}40 \text { to } 50 \\
\mathrm{~cm}\end{array}$ \\
\hline ST 37 & & $\mathrm{X}$ & & & \\
\hline
\end{tabular}




\section{DISCUSSION}

The site has a very thin scatter of lithic material on the surface. The heavily reworked Bandy/ Martindale dart point fragment suggests the site includes an Early Archaic component. One hearth feature and additional burned rock clusters are present. One shovel test indicates subsurface cultural material is present at the site.

This site is one in a cluster of sites within the Sacatosa Creek drainage and has the potential to contribute substantial data to the understanding of past human adaptations in this area of the Lower Pecos. Site 41 VV1689 is recommended as eligible for nomination to the National Register of Historic Places under Criterion D. In order to develop a data recovery plan, additional testing would be required.

\section{VV1690}

Site 41VV1690 (Figure 5-17) includes three concentrations of thermally altered rock which may be hearth remnants and one which is clearly a recent campfire. A few chert flakes are found on the surface of this site. This area is used for grazing livestock, and some recreational activities, as evidenced by the presence of the recent campfire, also take place along the creek.

\section{SITE SETTING}

\section{Topography}

The site is situated on the T1 terrace of Sacatosa Creek. The ground surface is almost level, sloping only slightly toward the creek. The majority of the site has been impacted by the blading of dirt roads and subsequent erosion. In some areas of the site small arroyos have developed in the road beds. The site datum is at an elevation of $312 \mathrm{~m}(1,020 \mathrm{ft})$ amsl, and is only about two feet above the level of the creek.

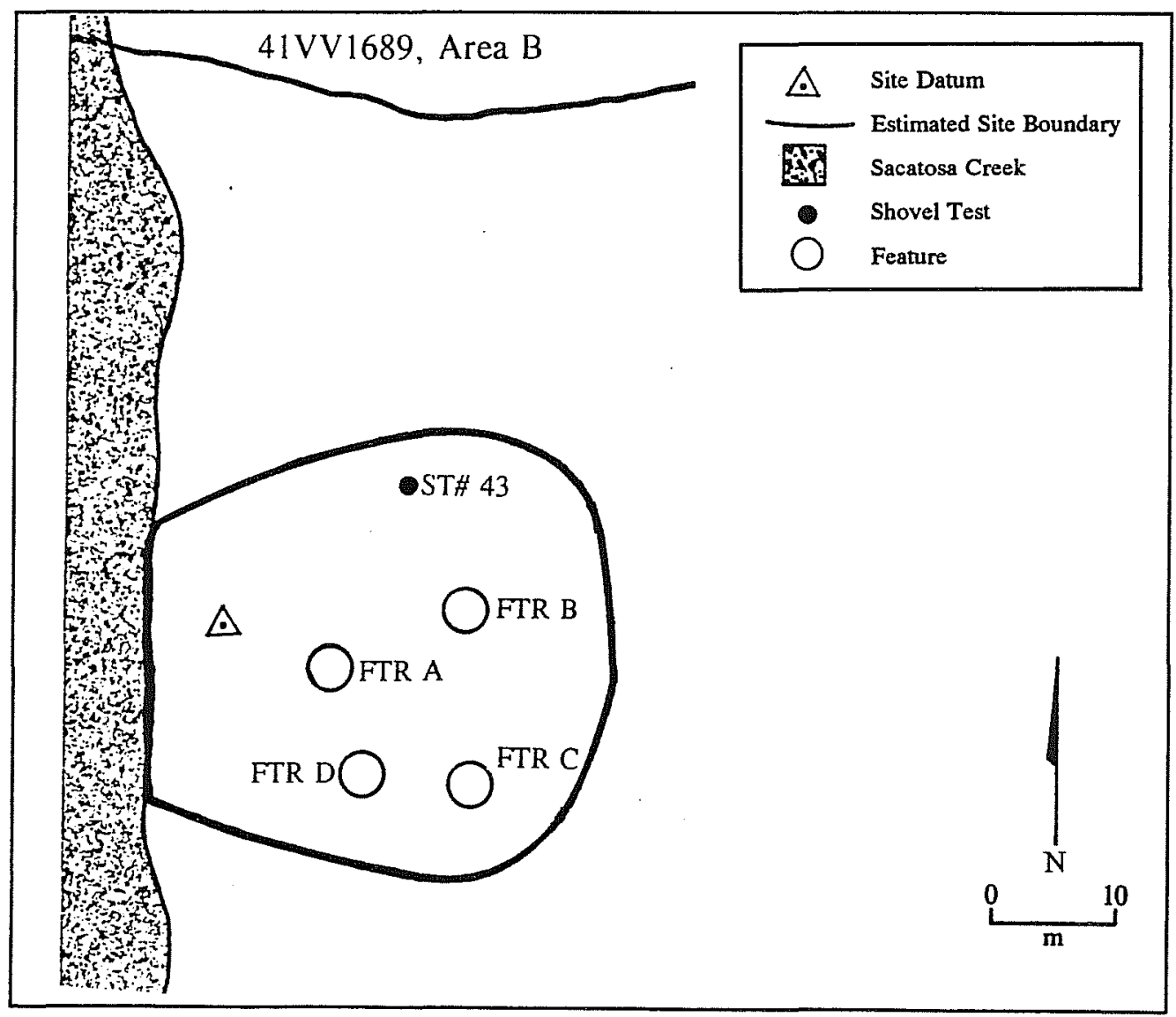

Figure 5-17. Site map, 41VV1690. 
Soils

The soils at the site are of the Pintas clay series, consisting of deep alluvial clays on the flood plains of small perennial streams (Golden et al. 1982:35-36, Map 55).

\section{Vegetation}

Site 41 VV1690 is associated with Sacatosa Creek. Due to the extensive blading of the surface for roads and grazing by livestock, however, much of the site is barren of vegetation. Large mesquite trees are growing along the creek bank and the northeastern boundary of the site includes the edge of a mesquite woods. A few cenizo and blackbrush acacia also are present (Everitt and Drawe 1993; Hatch and Pluhar 1993). A few closely cropped grasses were observed, but not identified. Between 80 and 100 percent of the site ground surface is visible.

\section{SITE DESCRIPTION}

41VV1690 is a site along the bank of Sacatosa Creek which exhibits evidence of the use of the area as a camp site. The site measures approximately $25 \times 25 \mathrm{~m}$, or $625 \mathrm{~m}^{2}$ in area. In addition to the presence of an obviously recent hearth, three concentrations of partially buried, thermally altered limestone cobbles also were observed. All three of these apparently non-recent features are eroding out of the dirt roads that cover most of the site. The site also included a very thin scatter of chert flakes, a thin ovate biface, and a Pedernales (4100 to 3200 B.P.) dart point stem.

Blading for dirt roads has removed approximately 2 to $10 \mathrm{~cm}$ of the modern ground surface and erosion has lowered the ground surface another 2 to $20 \mathrm{~cm}$ in certain areas. The surfaces of the three nonrecent, partially buried concentrations of thermally altered limestone (Features B, C, and D) are located between an estimated 5 to $10 \mathrm{~cm}$ below the modern ground surface (Figure 5-17).

\section{Features}

Feature $\mathrm{A}$ is a recent hearth or campfire composed of from 30 to 35 limestone river cobbles. It contains charcoal, a Styrofoam cartridge package, and the outer cardboard sleeve of the package identifying the cartridges as Winchester .38 caliber ammunition. Spent cartridges for .38 and .22 caliber weapons and shotgun shells were found around the modern hearth. The base of a Pedernales dart point was located a few centimeters from the edge of this recent feature. Whether the point was left there by recent campers who collected and then discarded or lost it, or by Middle Archaic-period peoples, is not known.

Feature $B$ is a roughly oval concentration of thermally altered limestone measuring approximately $1 \times 0.8 \mathrm{~m}$. This possible hearth remnant is located at the edge of a roadbed, approximately $15 \mathrm{~m}$ east of the site datum (Figure 5-17). The concentration consists of from 8 to 10 partially buried limestone cobbles and slabs, comprised of smooth and rounded river cobbles and the locally occurring, highly fossiliferous limestone that turns from a gold-tan color to a brick-red color when heated.

Feature $\mathrm{C}$ also designates a concentration of partially buried, thermally altered limestone eroding out of the middle of a road bed. This feature includes approximately 30 limestone river cobbles and fossiliferous limestone slabs, both of which exhibit evidence of thermal alteration. These stones occur within an oval area measuring approximately $1.5 \times 0.8 \mathrm{~m}$ in diameter. A scatter of recent charcoal was observed on the ground surface by Feature $C$; this charcoal was not obviously associated with this feature, and may rather reflect the modern usage of this area for recreational purposes.

Feature $D$ is a smaller and probably much more disturbed concentration of thermally altered limestone. It is located on the edge of a small arroyo that cuts into the road surface, approximately $10 \mathrm{~m}$ southeast of the site datum. About 10 pieces of thermally altered limestone are present, forming a rough semicircle approximately $0.5 \mathrm{~m}$ in width. The remainder of this feature appears to have been destroyed by erosion as it was cut by the arroyo.

\section{Dogleash-Unit Inventories}

No dogleash-unit inventories were conducted at site 41VV1690 because of the paucity of cultural material evident on the site surface. Only four widely spaced flakes, an ovate thin biface, and a Pedernales dart point stem were found at this site. The Pedernales dart point stem was recovered near Feature $A$, the modern hearth. The thin ovate biface was found in the northeastern part of the site, near the shovel test (Figure 5-17). 
Subsurface Testing

A single shovel test (ST 45) was excavated in the northeastern corner of the site (Figure 5-17). The shovel test profile revealed dark brown clay, containing no gravel, extending from the modern ground surface to a depth of $50 \mathrm{~cm}$. No cultural material was recovered from this shovel test.

\section{DISCUSSION}

Whether the Pedernales point represents debris imported to the campsite by modern campers or indicates a Middle Archaic component for this site is unknown. Although the results from the one shovel test were negative, material eroding from bladed areas indicates some archaeological deposits.

This small site also has been impacted by blading and other historic activities. 41VV1690 has only moderate research potential and considered alone would not be recommended for further investigation. However, because this site is one in a cluster of sites within the Sacatosa Creek drainage, it is recommended as eligible for nomination to the National Register of Historic Places under Criterion D. In order to develop a data recovery plan, additional testing would be required.

\section{VV1691}

Site 41VV1691 (Figure 5-18) is a lithic scatter located approximately $55 \mathrm{~m}$ southeast of site 41VV1690. The area is used for grazing livestock.

\section{SITE SETTING}

Topography

41VV1691 is situated on the T1 terrace of Sacatosa Creek. The ground surface is almost level, sloping only slightly to the west, toward the creek. The site elevation is approximately $312 \mathrm{~m}(1,020 \mathrm{ft})$ amsl.

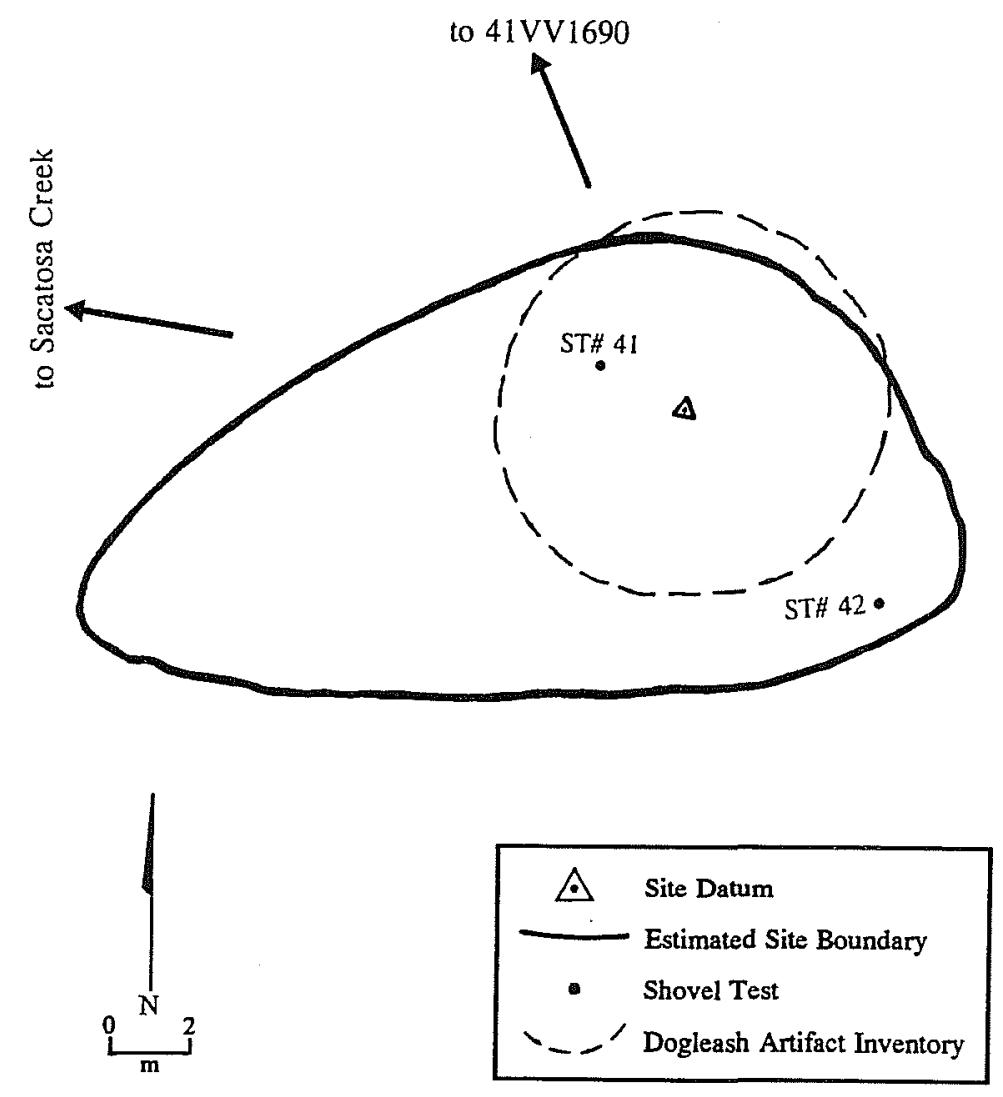

Figure 5-18. Site map, 41 VV1691. 
Soils

The site has soils of the Pintas clay series, consisting of deep alluvial clays on the flood plains of small perennial streams (Golden et al. 1982:35-36, Map 55).

\section{Vegetation}

Site 41VV1691 is creek-associated. The vegetation on the site reflects grazing by goats, cattle, and horses. The site lies in a small clearing in mesquite woods. The ground surface is largely barren, with only Texas prickly pear and a scatter of woody plants such as cenizo and blackbrush acacia present. The ground surface visibility is excellent, from 90 to 100 percent.

\section{SITE DESCRIPTION}

Site 41VV1691 is a small, sparse scatter of chert flakes. The site measures approximately $9 \times 21 \mathrm{~m}$, or $189 \mathrm{~m}^{2}$ in area.
Features

No cultural features were observed at this site.

Dogleash-Unit Inventories

A single dogleash-unit artifact inventory was conducted at site 41VV1691 (Figure 5-18). Table 5-22 lists the results of this inventory.

Subsurface Testing

Two shovel tests (STs 41 and 42) were excavated at site 41VV1691 (Figure 5-18). The sediments in both shovel tests were a uniform dark brown clay that extended from the modern ground surface to a depth of $50 \mathrm{~cm}$. A uniface fragment was recovered immediately below the ground surface in ST 41 . No artifacts were discovered in ST 42 (Table 5-23).

Table 5-22. Dogleash-Unit Inventory for Prehistoric Site 41VV1691

\begin{tabular}{|c|c|}
\hline Artifact Type & $\begin{array}{c}\text { Dogleash } \\
\text { Unit \#1 }\end{array}$ \\
\hline Primary flakes & 0 \\
\hline Secondary flakes & 1 \\
\hline Tertiary flakes & 4 \\
\hline Retouched flakes & 0 \\
\hline Unifaces (and fragments) & 0 \\
\hline Bifaces (and fragments) & 0 \\
\hline Projectile points (and fragments) & 0 \\
\hline Cores & 0 \\
\hline Tested cobbles & 0 \\
\hline Heat-spalled chert & 0 \\
\hline Thermally altered limestone & 0 \\
\hline Total & 5 \\
\hline
\end{tabular}

Table 5-23. Shovel Tests and Levels which Produced Artifacts on Site 41VV1691

\begin{tabular}{|c|c|c|c|c|c|}
\hline Shovel Tests & $\begin{array}{c}0 \text { to } 10 \\
\mathrm{~cm}\end{array}$ & $\begin{array}{c}10 \text { to } 20 \\
\mathrm{~cm}\end{array}$ & $\begin{array}{c}20 \text { to } 30 \\
\mathrm{~cm}\end{array}$ & $\begin{array}{c}30 \mathrm{to} 40 \\
\mathrm{~cm}\end{array}$ & $\begin{array}{c}40 \text { to } 50 \\
\mathrm{~cm}\end{array}$ \\
\hline ST 41 & $\mathrm{X}$ & & & & \\
\hline
\end{tabular}




\section{DISCUSSION}

The small size, low density, and lack of features and subsurface deposits at 41VV1691 indicate that this surface lithic scatter has limited research potential and if considered alone would not be recommended for further investigation. However, because this site is one in a cluster of sites within the Sacatosa Creek drainage, it is recommended as eligible for nomination to the National Register of Historic Places under Criterion D. In order to develop a data recovery plan, additional testing would be required.

\section{ISOLATED FINDS}

Descriptions for each of the 13 archaeological isolated finds (IF) found within the project area are provided in the following section. The isolated finds identified by CAR did not receive state trinomials. One isolated find (41VV1652, located by De Vore [1993]) was located in the west-central part of the base. Two isolated finds (IFs 6 and 8) were located in the north-central to northwestern part of the base, near the north base entrance. The remaining isolated finds were grouped in two general areas: the northeastern part of the base (IFs 1-5) and the southeastern part of the base (IFs 7 and 9-12).

\section{VV1652}

IF 41VV1652, located by De Vore (1993), consists of a probable Archaic chert projectile point (missing its base) and a 1940s .45 caliber steel-jacketed bullet. This isolated find is located in the northwestern part of the base, within the uplands biotic zone. The artifacts were situated along a dirt road. No other artifacts were located in this area.

\section{ISOLATED FIND 1}

IF 1 consists of a tertiary chert flake fragment located in the northeastern part of the base, within the upland flats biotic zone. No other artifacts were found within a $25-\mathrm{m}$ radius of this flake fragment, which was not collected.

\section{ISOLATED FIND 2}

A stoneware sherd with an early twentieth-century Albany and Bristol glaze was designated IF 2. The sherd was located in the center of a bladed dirt road in the northeastern part of the base, on the upland flats biotic zone. No other artifacts were found in the vicinity. This artifact was not collected.

\section{ISOLATED FIND 3}

IF 3 consists of a single secondary chert flake. It is located within the upland flats biotic zone, in the northeastern part of the base. No other artifacts were found in the area. This artifact was not collected.

\section{ISOLATED FIND 4}

Four chert flakes found within a 25-m diameter area were designated IF 4 . These flakes were located in the uplands biotic zone, near Sacatosa Creek. Broken chert cobbles also were present in this area, but did not appear to be the result of cultural activity. These flakes were not collected.

\section{ISOLATED FIND 5}

IF 5 was a large secondary deposit of recent construction debris found in an area approximately $20 \mathrm{~m}$ in diameter and $30 \mathrm{~cm}$ in depth. It is located in the upland flats biotic zone. Several bricks embossed with "D'HANIS" and a "CBMA" logo were observed at this location. Although more than four artifacts were present, the obviously secondary deposit was not considered a site. No artifacts were collected.

\section{ISOLATED FIND 6}

A worked secondary chert flake was designated IF 6 . This flake was found west of the main gate, in the uplands biotic zone, in the dirt berm of a bladed dirt road. No other artifacts were found in this area. The flake was not collected. 


\section{ISOLATED FIND 7}

IF 7 was a worked chert flake. This artifact was located in the creek zone near Sacatosa Creek. No other cultural material was found within a $25-\mathrm{m}$ radius around this find. It was not collected.

\section{ISOLATED FIND 8}

A thin, broken, chert biface, possibly a distal fragment of a dart point, was designated IF 8 . This biface fragment was located in the northern part of the base, in the upland flats biotic zone. The area is highly disturbed, and it was not evident whether this biface fragment was deposited in this area in prehistoric times or imported to the area during construction activities. No other artifacts were found in the vicinity. This artifact was collected.

\section{ISOLATED FIND 9}

IF 9 was a thin, pointed, chert biface distal fragment. This biface fragment was located in a rocky portion of a creek zone. No other artifacts were observed in the area. This artifact was collected.

\section{ISOLATED FIND 10}

A corner-notched point probably dating to the Early Archaic period-8000 to 4000 B.P. (Turner and Hester 1993:78)-was designated IF 10. This dart point was located in the creek zone which has sparse vegetation. No other artifacts were observed nearby. The point was collected.

\section{ISOLATED FIND 11}

IF 11 was a crude basalt biface fragment. It was located within the creek zone. This artifact was collected because it was a type of stone not seen on the base.

\section{ISOLATED FIND 12}

A pointed, thin chert biface fragment was designated IF 12. This artifact was located on a rocky, sparsely vegetated area within the upland biotic zone. The artifact was collected. 


\section{Chapter 6. Prehistoric Artifacts}

\section{Cynthia L. Tennis}

\section{INTRODUCTION}

Prehistoric artifacts recorded and/or collected from the surface during the Laughlin Air Force Base Survey include 1,511 lithics, listed in Table 6-1. Also recorded were ground stone $(n=1)$, thermally altered chert $(n=55)$, and burned limestone $(n=342)$. These surface artifacts were identified and recorded within
29 controlled 10-m-diameter dogleash units on 11 of the 12 prehistoric sites (see Chapter 5 for details). An additional 13 surface lithics were recorded away from the sites as Isolated Finds. Diagnostic projectile points as well as a representative sample of unifaces, bifaces, and cores were collected. The following characteristics were used in the field to classify prehistoric lithic material.

Table 6-1. Dogleash Sample Unit Artifacts

\begin{tabular}{|c|c|c|c|c|c|c|c|c|}
\hline Area & $\begin{array}{l}\text { Prim. } \\
\text { Flake }\end{array}$ & $\begin{array}{l}\text { Sec. } \\
\text { Flake }\end{array}$ & $\begin{array}{l}\text { Tert. } \\
\text { Flake }\end{array}$ & $\begin{array}{l}\text { Retouched } \\
\text { Flake }\end{array}$ & $\begin{array}{c}\text { Uniface } \\
\text { \& Frags }\end{array}$ & $\begin{array}{c}\text { Biface } \\
\& \\
\text { Frags }\end{array}$ & $\begin{array}{l}\text { Points } \\
\text { \& Frags }\end{array}$ & $\begin{array}{c}\text { Cores \& } \\
\text { Tested } \\
\text { Cobbles }\end{array}$ \\
\hline IF1 & & & 1 & & & & & \\
\hline IF3 & & 1 & & & & & & \\
\hline IF4 & 4 & & & & & & & \\
\hline IF6 & & & & 1 & & & & \\
\hline IF7 & & & & 1 & & & & \\
\hline IF8 & & & & & & 1 & & \\
\hline IF9 & & & & & & 1 & & \\
\hline IF10 & & & & & & & 1 & \\
\hline IF11 & & & & & & 1 & & \\
\hline IF12 & & & & & & 1 & & \\
\hline $41 \mathrm{VV} 1653$ & 1 & 3 & 16 & & & & & 1 \\
\hline 41VV1654 & 24 & 104 & 157 & 3 & 3 & 3 & 6 & 7 \\
\hline 41VV1655 & 12 & 16 & 2 & & & & & 14 \\
\hline 41VV1683 & 18 & 5 & 7 & 5 & & 1 & 1 & 3 \\
\hline 41VV1684 & & 3 & 12 & & & & & \\
\hline $41 \mathrm{VV} 1685$ & 215 & 392 & 178 & 54 & 4 & 15 & 2 & 86 \\
\hline 41VV1686 & 3 & 18 & 21 & & & 4 & & 1 \\
\hline 41VV1687 & 4 & 19 & 9 & 2 & 1 & & & \\
\hline 41VV1688 & & 10 & 13 & & & 1 & 3 & \\
\hline 41VV1689 & & 3 & 1 & & & & 1 & \\
\hline 41VV1690 & & & 4 & & & 1 & 1 & \\
\hline $41 \mathrm{VV} 1691$ & & 1 & 4 & & & & & \\
\hline TOTAL & $\begin{array}{c}281 \\
(18.5 \%)\end{array}$ & $\begin{array}{c}575 \\
(38 \%) \\
\end{array}$ & $\begin{array}{c}425 \\
(28 \%) \\
\end{array}$ & $\begin{array}{c}66 \\
(4 \%) \\
\end{array}$ & $\begin{array}{c}8 \\
(.5 \%) \\
\end{array}$ & $\begin{array}{c}29 \\
(2 \%) \\
\end{array}$ & $\begin{array}{c}15 \\
(1 \%) \\
\end{array}$ & $\begin{array}{c}112 \\
(8 \%) \\
\end{array}$ \\
\hline
\end{tabular}


Primary flake: 100 percent cortex on dorsal face; striking platform and bulb of percussion present.

Secondary flake: 1-99 percent cortex on dorsal face; striking platform and bulb of percussion present.

Tertiary flake: 0 percent cortex on dorsal face; striking platform and bulb of percussion present.

Retouched flake: flake with platform and bulbs of percussion remaining; has evidence of retouching on some edges.

Uniface: worked flake with intentional flaking on one face only.

Biface: flakes removed from both sides to shape object.

Cores and Tested Cobbles: parent material from which flakes have been detached. Cores exhibit numerous scars from flake removal while tested cobbles show evidence of only minimal flake removal.
Point and Point Fragment: complete or partial projectile point.

Chips and chunks: debitage not exhibiting striking platforms or bulbs of percussion, but exhibiting conchoidal fractures. Because of the high density of naturally occurring chert nodules over much of the tested area and the difficulty distinguishing between culturally manufactured and naturally occurring chert chips and chunks from surface contexts, this category of lithics was systematically recorded for subsurface testing only.

Thermally altered chert: discolored chip, chunks, or nodules with pot-lid fractures.

Thermally altered limestone: reddened or angularly fractured fossiliferous limestone.

Of the 88 shovel tests dug during this survey, 30 produced 89 lithic artifacts. These lithics are shown, by site, in Table 6-2.

Table 6-2. Shovel Tests Artifacts

\begin{tabular}{|c|c|c|c|c|c|c|c|}
\hline Location & $\begin{array}{l}\text { Chips \& } \\
\text { Chunks }\end{array}$ & $\begin{array}{l}\text { Prim. } \\
\text { Flake }\end{array}$ & $\begin{array}{l}\text { Sec. } \\
\text { Flake }\end{array}$ & $\begin{array}{l}\text { Tert. } \\
\text { Flake }\end{array}$ & $\begin{array}{c}\text { Uniface } \\
\& \\
\text { Frags. }\end{array}$ & $\begin{array}{l}\text { Biface } \\
\quad \& \\
\text { Frags }\end{array}$ & $\begin{array}{c}\text { Cores \& } \\
\text { Tested } \\
\text { Cobbles }\end{array}$ \\
\hline $41 \mathrm{VV} 1654$ & 25 & 2 & 11 & 7 & 4 & 1 & 1 \\
\hline 41VV1655 & & 1 & 2 & & & & \\
\hline 41VV1683 & 7 & & 1 & 3 & & 1 & \\
\hline 41VV1684 & 1 & & 1 & & & & \\
\hline 41VV1685 & 1 & & 1 & 1 & & 1 & 1 \\
\hline 41VV1686 & & & 1 & 1 & & & 1 \\
\hline 41VV1687 & & & 3 & 2 & & & 1 \\
\hline 41VV1688 & 2 & & & 3 & & & \\
\hline $41 V V 1689$ & & & & & & & 1 \\
\hline \multicolumn{8}{|l|}{$41 \mathrm{VV} 1690$} \\
\hline $41 V V 1691$ & & & & & 1 & & \\
\hline TOTAL & $\begin{array}{c}36 \\
(40 \%)\end{array}$ & $\begin{array}{c}3 \\
(3 \%)\end{array}$ & $\begin{array}{c}20 \\
(23 \%)\end{array}$ & $\begin{array}{c}17 \\
(19 \%)\end{array}$ & $\begin{array}{c}5 \\
(6 \%)\end{array}$ & $\begin{array}{c}3 \\
(3 \%)\end{array}$ & $\begin{array}{c}5 \\
(6 \%)\end{array}$ \\
\hline
\end{tabular}




\section{ARTIFACT DESCRIPTIONS}

As described in the laboratory section of Chapter 3, all artifacts were given a catalog number consisting of the site trinomial and a sequential number or, in the case of isolated finds, the IF number and "LGH" for Laughlin AFB. Selected fields of the artifact catalog are presented in Appendix D.

\section{PROJECTILE POINTS}

Of the 14 points and point fragments recovered, 13 were from the surface of 6 sites, and 1 was an isolated surface find. Based on Turpin (1991), these diagnostics represent a time span of 8,000-9,000 years-from the Late Paleoindian to the Late Prehistoric. The points are discussed by provenience.

\section{IF 10 (IF10LGH-001)}

This is an almost complete point with a concave base and corner-notched stem, characteristic of the Early Corner-notched point types associated with the Early Archaic in the Lower Pecos (Figure 6-1a). The material is a pinkish-gray chert with moderate patination on both sides. The distal tip and both barbs are missing. Maximum thickness of this point is $4.5 \mathrm{~mm}$.

\section{VV1654}

Three identifiable points and three unidentifiable point fragments were recovered during surface inspection of this site, originally recorded in 1992 by De Vore (1993).

The three identified point types from 41VV1654 are associated with the Late Paleoindian and Early Archaic time periods. 41VV1654-065 is a nearly complete Golondrina/Barber type point (Figure $6-1 b)$. It is heavily patinated with broad parallel flaking on one side and ground edges on both sides of the stem. Point dimensions are: length $=47 \mathrm{~mm}$, width $=28 \mathrm{~mm}$, and thickness $=5 \mathrm{~mm}$. Specimen 41VV1654-006 (Figure 6-1c) is an almost complete Wilson point made of gray-brown chert. It is side notched with edge grinding on both the stem and base. The tip of this point is missing. Maximum width is $25.5 \mathrm{~mm}$ and maximum thickness is $7 \mathrm{~mm}$. Specimen 41VV1654-066 (Figure 6-1d) is a lightly patinated Gower point made of tan-colored chert. This small point is $29 \mathrm{~mm}$ long, $19.5 \mathrm{~mm}$ wide, and $5 \mathrm{~mm}$ thick.

The three unidentified points from 41VV1654 include: 41VV1654-024, a straight-stemmed, beveled fragment with corner notches (Figure 6-1e); 41VV1654-011, a broad, heavily patinated, triangular fragment with corner notching and a reworked spokeshave-like concavity along one edge (Figure 6-1f); and 41VV1654-064, a small, heavily patinated, non-chert fragment with a slightly concave proximal section (Figure 6-1g).

\section{VV1683}

Specimen 41VV1683-003 is an Angostura-like point fragment (Figure 6-1h). It is made of dark brown chert and is heavily patinated on one side. The distal tip of this point shows signs of retouch. Positive identification of this point is not possible as the proximal end is missing; however, the pattern of parallel flake scars on one side and the alternately beveled edges are characteristic of the Angostura type. This point is $19.5 \mathrm{~mm}$ wide and $5 \mathrm{~mm}$ thick.

\section{VV1685}

The two projectile point fragments from this site (4IVV1685-003 and -014) are both distal portions with mid-shaft hinge-fractures (Figures 6-1i and $\mathrm{j}$ ). One is made from dark brown chert material, the other from light tan chert. Neither shows parallel flake scars or evidence of edge grinding. Point -003 is $33 \mathrm{~mm}$ wide and $8 \mathrm{~mm}$ thick, -014 is $24 \mathrm{~mm}$ wide and $6 \mathrm{~mm}$ thick.

\section{VV1688}

Two diagnostic points were recovered from this site. Specimen 41VV1688-001 (Figure 6-1k) is a shallowly side-notched, straight-based Kinney-like point. It is $58.5 \mathrm{~mm}$ long, $26 \mathrm{~mm}$ wide, and $5.5 \mathrm{~mm}$ thick. Specimen 41VV1688-005 (Figure 6-11) is an Ensor point. It is side notched with a broad stem and straight base, and appears to have been thermally altered. The tip of this point is broken; it measures $20 \mathrm{~mm}$ wide and $6 \mathrm{~mm}$ thick. These points span the Late Archaic and Late Prehistoric periods in this region (Turpin 1991). 

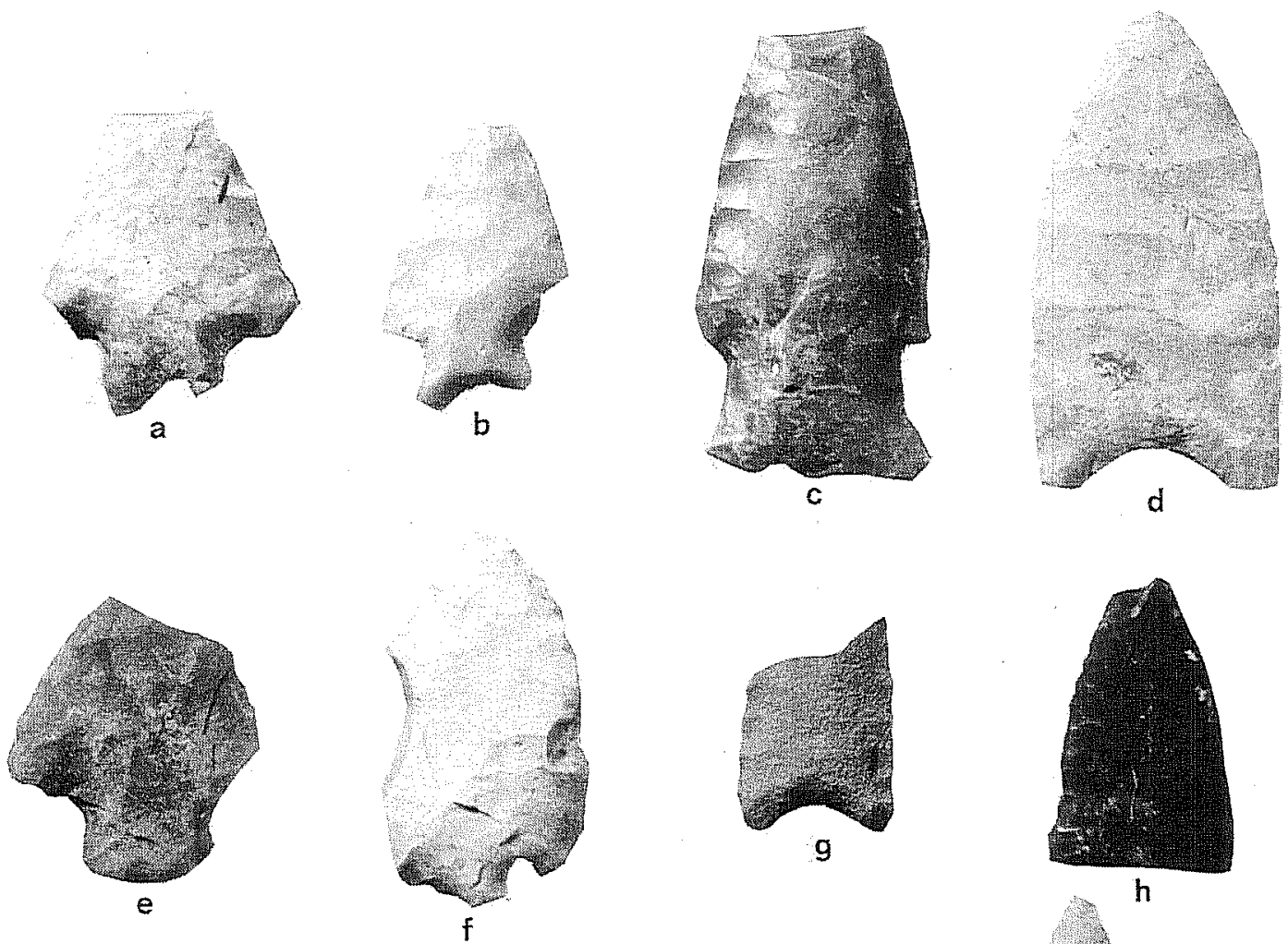

h
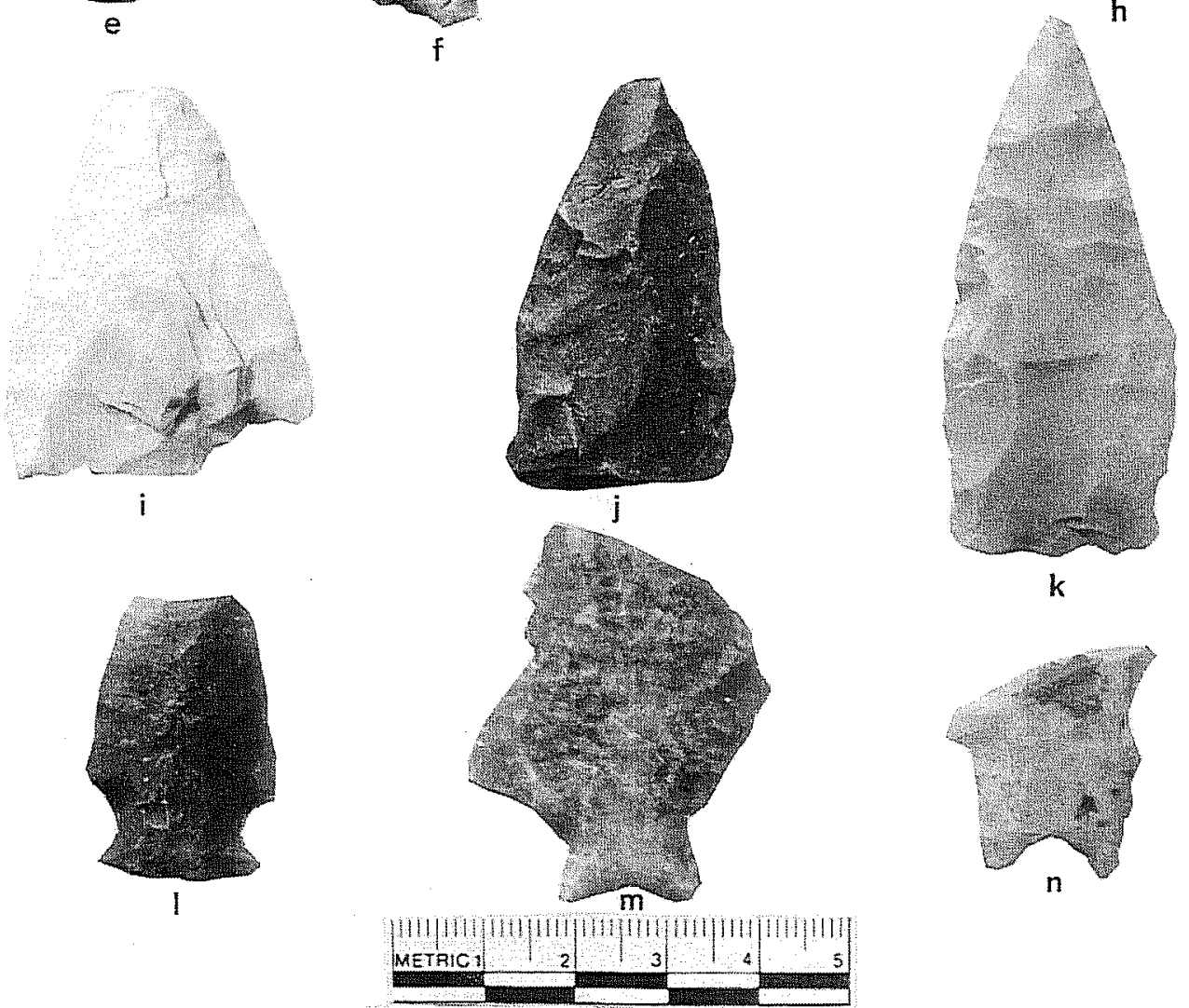

Figure 6-1. Projectile points. IF10- a: Early Corner-notched; 41VV1654- b: Golondrina/Barber; c: Wilson; d: Gower; e-g: unidentified; 41VV1683- h: Angostura-like; 41VV1685-i, j: unidentified; 41VV1688- k: Kinneylike; l: Ensor; 41VV1689- m: Bandy/Martindale; 41VV1690- n: Pedernales-like. 


\section{VV1689}

One heavily reworked Early Archaic Bandy/ Martindale fragment (41VV1689-001) was collected from this site. This point is made from brown chert and has the distinc-tive fishtail-shaped base. Both of the barbs and the distal tip of this point are missing. It is $3 \mathrm{~mm}$ thick (Figure 6-1m).

\section{VV1690}

The basal section of a small, 3-mm-thick Pedernales-like point (41VV1690-002) was recovered from a modern hearth on this site. The classic rectangular, bifurcated stem and broad, flute-like thinning flake are characteristic of Pedernales, but this point is small for the type. It is made of rosecolored chert and is characteristic of the Middle Archaic time period (Figure 6-1n).

\section{BIFACE TOOLS (Figures 6-2 and 6-3)}

Of the 32 bifacially modified chert artifacts recorded during the survey, 29 were found on the surface and 3 were recovered from shovel tests. Twenty-three of these bifaces were collected and are described below by site. Measurements for bifacial tools are given in Table 6-3.

Four bifaces fragments, designated as Isolated Finds, were recorded outside identified site boundaries. IF 8 (Figure 6-2a) and IF 12 (Figure 6-2b) were found in upland flats; IF 9 (Figure 6-2 c) and IF 11 (Figure 6-2d) were from rocky areas in the creek zone. IF 11 is a crude biface fragment made from basalt, the others are thin, pointed, chert fragments, possibly distal portions of projectile points.

Seven thin bifaces were recovered from 41VV1654, six (41VV1654-001, -002, -013, -019, -025, and -030 ) from the surface. These include distal, medial, and proximal sections (Figures 6-2e-j), with 41VV1654-001 showing evidence of thermal alteration. One rectangular-shaped thin biface (41VV1654-016) with alternately beveled edges (Figure 6-2k) was recovered from a shovel test.

One surface biface (41VV1683-005) and one subsurface biface (41VV1683-004) were recovered from 41VV1683 (Figures 6-2l, m). Both are thin, brown chert, distal fragments. Specimen 4IVV1683-
005 is finely flaked with serrated, alternately beveled edges.

Of the five bifaces recovered from 41VV1685, two (41VV1685-009 and -010) are thin, leaf-shaped forms made up of two conjoining pieces that appear to have been broken during manufacture (Figures 6-3a, b). Two thick bifaces also came from this site. Specimen 41VV1685-005 (Figure 6-3c) is made on a small circular pebble that retains approximately 80 percent of the cortex on both sides and has been bifacially worked on one end. Specimen 41VV1685006 (Figure 6-3d) has irregular edges that narrow toward one flattened end and retains 90 percent of the cortex on one side. Specimen 41VV1685-008 (Figure 6-3e) is a heavily patinated, rectangular biface with three beveled edges. One large flake scar runs the entire length of one side of this gouge-like artifact.

Three thin, bifacially worked lithics were collected from the surface at 41VV1686. Specimen 41VV1686004 (Figure 6-3f) is a very small, moderately patinated oval biface. Specimen 41VV1686-001 (Figure 6-3g) is a heavily patinated basal section with a broad rounded base. Specimen 41VV1686-005 (Figure 6-3h) is moderately patinated with a square base, one finished straight edge, and one uneven/ unfinished edge.

One small, thin, lanceolate-shaped biface, 41VV1688-004 (Figure 6-3i), was found on the surface at 41VV1688. One thin, lanceolate biface (41VV1690-001) made of rose-colored chert was also recovered from $41 \mathrm{VV} 1690$ (Figure 6-3j).

\section{UNIFACE TOOLS}

Thirteen unifacially modified flakes were identified from four sites at Laughlin AFB. Two of the unifaces recovered from below the surface (41VV1654-004 and -069) are circular in shape with steeply modified edges. Four unifaces were recovered on the surface at 41VV1685, one of which (41VV1685-004) is a semicircular, expanding uniface still exhibiting remnants of a prepared platform and a large bulb of percussion. One uniface was observed on the surface at 41VV1691 and one large unifacially modified flake (41VV1691-001) was recovered from a shovel test at 41VV1691. 


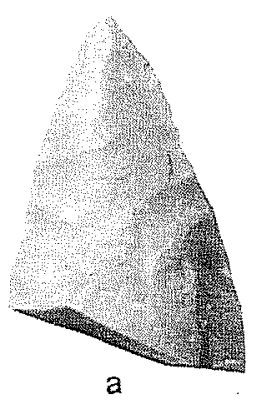

a
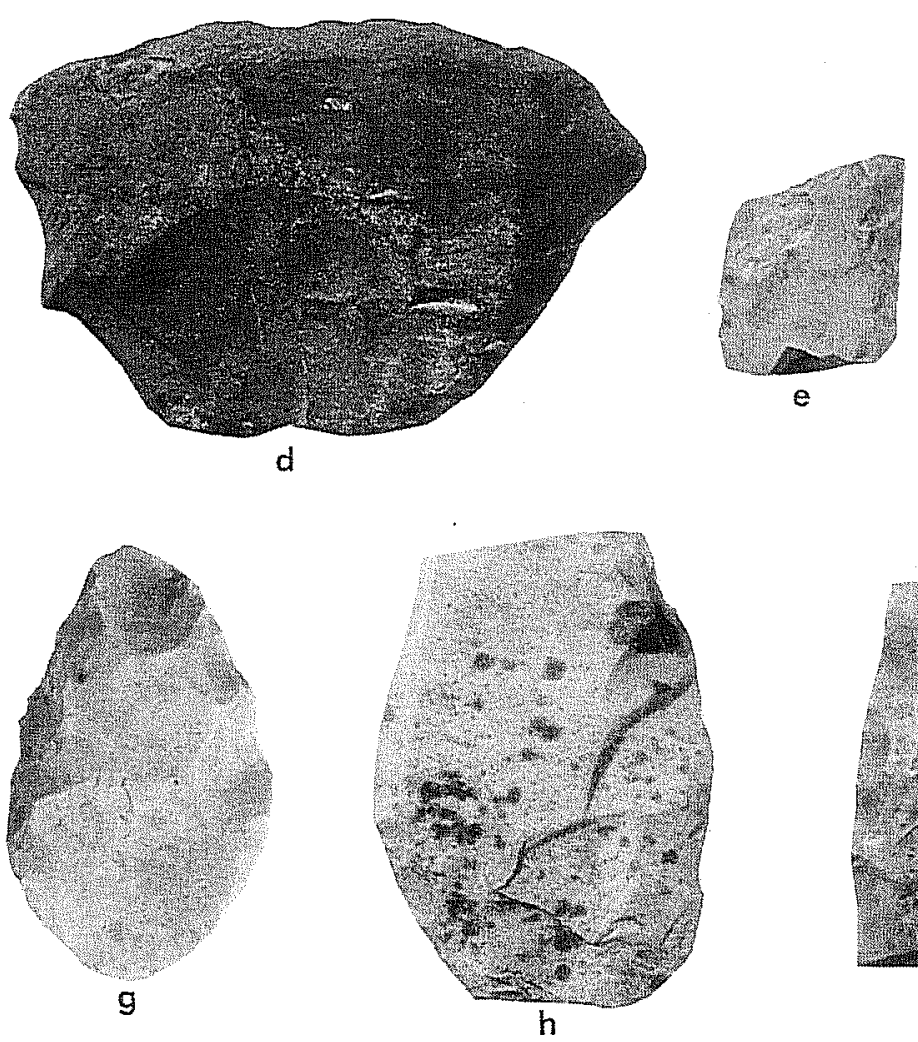

b
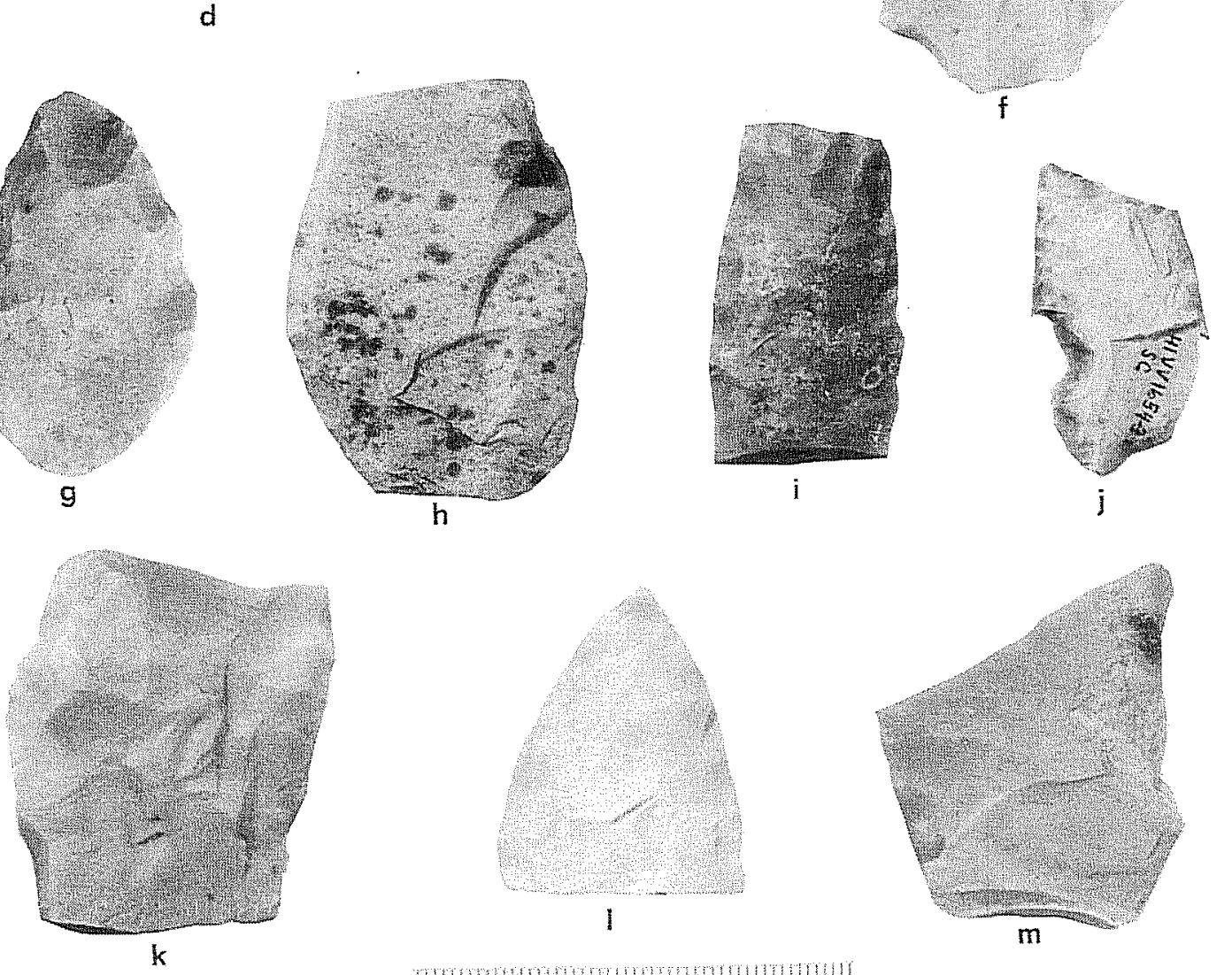

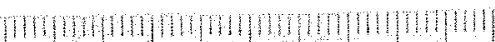

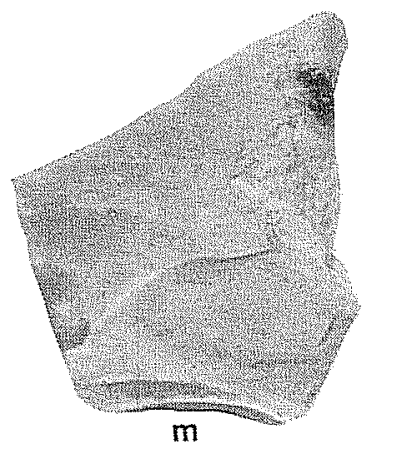

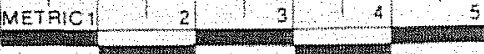
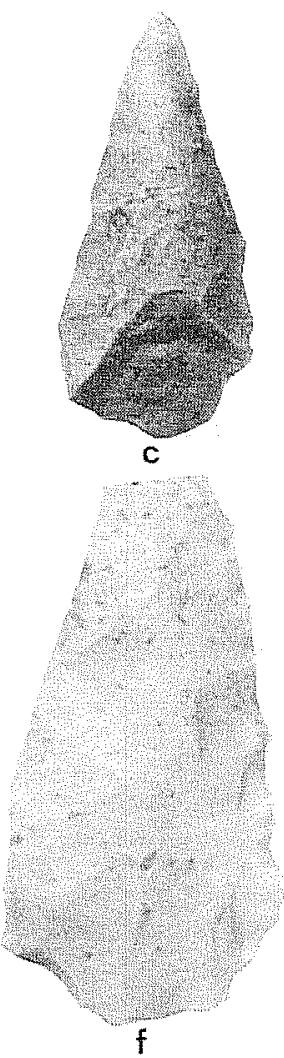


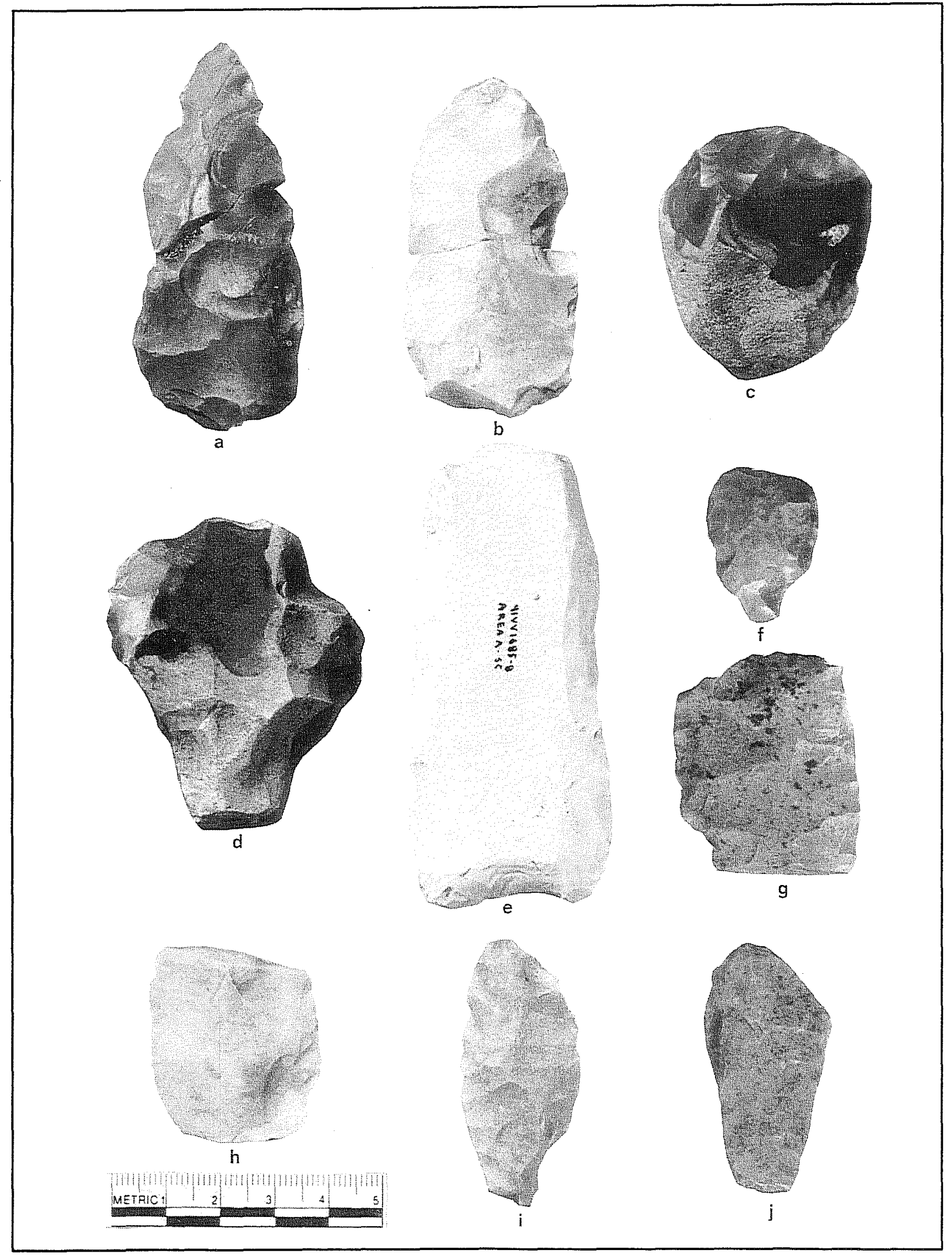

Figure 6-3. Biface tools. 41VV1685- a-e; 41VV1686- f-h; 41VV1688- i, j. 
Table 6-3. Biface and Uniface Tool Dimensions

\begin{tabular}{|c|c|c|c|c|}
\hline & Artifact & $\begin{array}{l}\text { Width } \\
\text { (mm) }\end{array}$ & $\begin{array}{l}\text { Length } \\
(\mathbf{m m})\end{array}$ & $\begin{array}{l}\text { Thickness } \\
\text { (mm) }\end{array}$ \\
\hline \multirow{23}{*}{$\begin{array}{l}\frac{\infty}{8} \\
\stackrel{0}{0} \\
\stackrel{\oplus}{\oplus}\end{array}$} & IF8-1 & 23 & - & 5.5 \\
\hline & IF9-1 & 19 & - & 8 \\
\hline & IF11-1 & 64 & 47 & 12 \\
\hline & IF12-1 & 37 & - & 4.5 \\
\hline & $1654-1$ & 13 & - & 5 \\
\hline & $1654-2$ & 28 & - & 7 \\
\hline & $1654-13$ & 27 & 44.5 & 8 \\
\hline & $1654-16$ & 35 & - & 10 \\
\hline & $1654-19$ & 34 & - & 8 \\
\hline & $1654-25$ & 23 & - & 8 \\
\hline & $1654-30$ & 19 & 36 & 4 \\
\hline & $1683-4$ & 37 & - & 7 \\
\hline & $1683-5$ & 29 & - & 8 \\
\hline & $1685-2$ & 26 & - & 4 \\
\hline & $1685-5$ & 39 & 47 & 16 \\
\hline & $1683-6$ & 46 & 53 & 16 \\
\hline & $1685-9$ & 34 & 73 & 9 \\
\hline & $1685-10$ & 30.5 & 64 & 11 \\
\hline & $1686-1$ & 34.5 & - & 6 \\
\hline & $1686-4$ & 21 & 29.5 & 6 \\
\hline & $1686-5$ & 31 & - & 7 \\
\hline & $1688-4$ & 23 & 51 & 9 \\
\hline & $1690-1$ & 24 & - & 7 \\
\hline \multirow{5}{*}{ 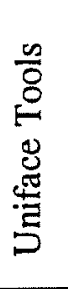 } & $1654-4$ & 29 & 50 & 9 \\
\hline & $1654-69$ & 37 & 38 & 17 \\
\hline & $1684-1$ & 35 & 43 & 16 \\
\hline & $1685-4$ & 34 & 48 & 13 \\
\hline & $1691-1$ & 24 & 56 & 15 \\
\hline
\end{tabular}




\section{CORES}

Five chert cores, including one multidirectional core and one core tool, were collected from shovel test excavations. An additional 55 cores were recorded in dogleash areas, 40 from 41 VV1685. Fifty-seven tested cobbles were also recorded, 46 from 41VV1685. Core materials appears to be from locally occurring chert outcrops in the limestone bedrock or late Pliocene and early Pleistocene gravels common in the uplands.

\section{GROUND STONE}

One piece of ground stone, identified as a limestone pestle (Figure 6-4), was collected from 41VV1654. This pestle is $34.5 \mathrm{~cm}$ long and has a maximum diameter of $20 \mathrm{~cm}$. This pestle, which has been shaped overall by pecking and grinding, displays two patterns of use. One end is sub-conical in shape and displays asymmetrical grinding or polishing on a 3.5$4 \mathrm{~cm}$ area of this overall pecked surface. Several parallel lines running perpendicular to the long axis are indicative of rotary motion. The $2 \mathrm{~cm}$ tip of the broader end has been flattened by pounding. Thesepatterns are consistent with wear expected from use in circular bedrock mortar holes known to occur in sites along the canyon (Pearce and Jackson 1933; Shafer 1986). This piece of ground stone was found in disturbed context in the wall of a military foxhole.
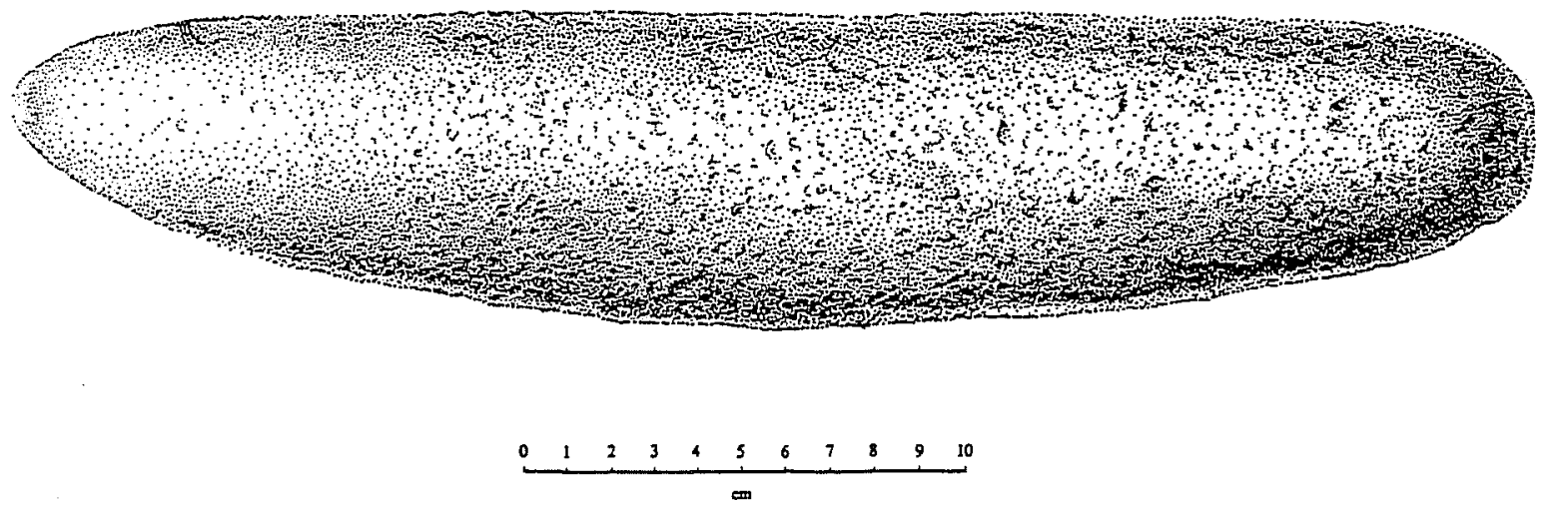

Figure 6-4. Ground stone pestle, from site 41VV1654. 


\section{Chapter 7. Prehistoric Analysis}

\section{Gerry R. Raymond, Robert J. Hard, and Cynthia L. Tennis}

The purpose of this project was to evaluate, through survey and shovel testing, the extent of the historic and prehistoric use and occupation of Laughlin AFB and the nature of that use and occupation. Within those general parameters, several research questions were addressed concerning the prehistoric adaptations. The following analyses of assemblage composition, site use, settlement patterns, and formation processes relate to prehistoric utilization of the base area.

\section{GENERAL SUMMARY}

Of the approximately 4,145 acres comprising the miliary base, about 1,300 acres were excluded from the survey. These areas are part of the runway system, were otherwise altered, or were inaccessible due to military operations. The remaining 2,845 acres were divided into three zone for the purpose of this analysis. The developed zone contains about 850 acres located in the upland hills and flats, but is comprised largely of housing and buildings with yards and maintained grass fields with little or no ground visibility. The upland zone (excluding the developed portions) is made up of about 1,471 acres of gentle hills, flats, and valley fills away from the creek zones. The creek zones total about 533 acres including the floodplain, the associated terraces, and $100 \mathrm{~m}$ bordering the floodplain where there are no terraces.

Twelve prehistoric sites were identified on the base, including the three sites (41VV1653, 41VV1654, and $41 V V 1655$ ) originally identified by Steven De Vore (1993). A small lithic scatter, 41VV1653, was located on the valley slope overlooking Zorro Creek in the northwest part of the base. Only one site, 41VV1684, was located in the upland area of the base; however, this small lithic scatter was in the developed, central part of the base and shovel testing of the site indicated a disturbed matrix of imported fill material. The 10 other sites were located along
Sacatosa Creek in the eastern and southeast part of the base.

Four sites are located on the west terrace (T2) of Sacatosa Creek and include a very large, dense lithic scatter (41VV1685), two small lithic scatters (41VV1655 and 41VV1683), and an extensive site (41VV1654) in which numerous lithic scatters and areas of thermally altered limestone representing a range of activities at the site were identified. Of these west terrace sites, two are extensive in area. Site $41 \mathrm{VV} 1654$ contains about $585,200 \mathrm{~m}^{2}$ and runs from the upper reaches of the west terrace down into the floodplain. Site 41VV1685 contains about $72,800 \mathrm{~m}^{2}$, with the southern portion situated on exposed bedrock bluffs overlooking the creek. This site contains extensive deposits of chert cobbles and nodules and appears to have been a source of lithic raw material for the area. The other two west terrace sites, 41VV1655 and 41VV1683, were much smaller, containing $4,500 \mathrm{~m}^{2}$ and $16,200 \mathrm{~m}^{2}$ respectively.

The remaining six sites (41VV1686-1691) were clustered along the east side of Sacatosa Creek on the lower portion of the eastern terrace (T1) abutting the floodplain (T0) in the southeastern part of the base. Three hearth features were found at one site (41VV1686) and possible hearth remnants and thermally altered limestone were found at four of the other sites. One of the sites (41VV1691) is a thin lithic scatter with no features. Five of the six sites produced subsurface material ranging in depths to 30 $\mathrm{cm}$ below the surface. Limited amounts of primary, secondary, and tertiary flakes were identified at all of the sites, and only a few bifaces or bifacial fragments were recovered in addition to the projectile points. Only one of these sites produced worked flakes or unifacial type tools. All the east terrace sites were smaller than those on the west side. The largest, $41 \mathrm{VV1} 1688$, contains about $12,800 \mathrm{~m}^{2}$. The other five range in size from $2,800 \mathrm{~m}^{2}$ to $60 \mathrm{~m}^{2}$. 
The nine diagnostic projectile points recovered from the surface survey reflect occupation and use of the base from the Late Paleoindian through the Late Prehistoric period, a span of about 8,000 years. The chipped stone assemblage consists of projectile points, worked flakes, unifaces, and thin and thick bifaces, unmodified flakes, and lithic debris which is consistent with the lithic technology employed throughout the Lower Pecos region. All the projectile points were made from chert of varying characteristics, including a wide range of colors. Although sourcing of the materials was beyond the scope of this project, the material used for the points is within the range of characteristics of chert found in the base area. While occasional cobbles and nodules of chert are found throughout the base area, the terraces and bluffs along the west side of Sacatosa Creek are rich in chert cobbles, nodules, and outcrops and would have provided a local source of lithic material.

Ten prehistoric isolated finds were observed during the survey, from which 13 artifacts were recorded. Nine of the artifacts were in the uplands, including 6 pieces of chert debitage, 1 worked chert flake, and 2 chert bifaces. The terrace/creek zone contained 4 isolates including 1 worked chert flake, 1 chert biface, 1 basalt biface, and 1 Early Archaic chert point.

\section{ANALYSIS}

The lithic assemblage recorded within surface dogleash units is analyzed to search for patterns related to site function and land-use patterns in areas removed from the rock shelters and major drainages in the region. All but one of the sites recorded during the survey are within $100 \mathrm{~m}$ of either Zorro or Sacatosa creeks and therefore fall within our classification of creek zone sites. For this analysis, however, the prehistoric creek zone sites have been further subdivided, based on topographic location, into bluff/terrace sites and floodplain sites as shown in Table 7-1.

Three floodplain sites, 41VV1689, 41VV1690, and 41VV1691 are excluded from the quantitative comparisons because of the small number of artifacts recorded in the dogleash sample units ( $n=6$ for each site); 41VV1684, an upland site, is excluded from all analysis because of the highly disturbed nature of the site.

\section{TEMPORAL DISTRIBUTION}

Two of the four bluff/terrace sites, 41VV1654 and 41VV1683, contained diagnostic points. The four points from these two sites-Angostura, Golondrina/ Barber, Gower, and Wilson-are all associated with either the late Paleoindian or the Early Archaic time periods. Three of the four floodplain sites contained diagnostics. Of these, the reworked Bandy/ Martindale from 41 VV1689 is associated with the Early Archaic. The Ensor and Kinney-like points from 41VV1688 and the Pedernales-like point from 41VV1690 are characteristic of the Middle Archaic to Late Prehistoric time periods. This spatial distribution of diagnostic points from different time periods suggests a pattern of bluff/terrace land use during the Late Paleoindian and Early Archaic periods and a possible shift to floodplain land use after the Middle Archaic.

However, this spatial/temporal distribution of the projectile points may be accounted for by depositional and erosional processes. The geoarchaeological evaluation indicates that Paleoindian sites and artifacts, not removed by later erosional events, may

Table 7-1. Creek Zone Subdivisions

$\begin{array}{cc}\text { Bluff/Terrace Sites } & \text { Floodplain Sites } \\ \text { 41VV1654 } & 41 \mathrm{VV} 1653 \\ 41 \mathrm{VV} 1655 & 41 \mathrm{VV} 1686 \\ 41 \mathrm{VV} 1683 & 41 \mathrm{VV} 1687 \\ 41 \mathrm{VV} 1685 & 41 \mathrm{VV} 1688\end{array}$


be buried in channel scours of the floodplain in stratigraphic Unit II, an alluvial deposition that coincides with an early Holocene mesic interval (Nordt, this volume). Early Archaic material may be buried within the upper $40 \mathrm{~cm}$ of stratigraphic Unit III along the lower east terrace (T1) of Sacatosa Creek where deposition did not begin much earlier than 6500 B.P. However, deposits below $40 \mathrm{~cm}$ were highly disturbed by channel activity that would make intact cultural deposits unlikely on the west side of Sacatosa Creek (Nordt, this volume). Middle and Late Archaic material may be buried in the gully-fills dissecting the bluffs and terraces (T2).

The juxtaposition of the floodplain and the bluff/ terraces-each with critical resources for the area, water and chert-and the facility of movement between the two land forms may indicate that these empirical observations are a product of the method of analysis, i.e. the subdivision of the creek zone, sample size (nine diagnostic points), or the geomorphology, rather than the utilization of one area in a particular period to the exclusion of the other area. However, shifts in the nature of the land use and in the technological organization may have occurred. These shifts could account for the distribution (as almost all expedient tool types, such as retouched flakes and unifaces, were on bluff/terraces sites). Some aspects of this issue could be addressed with further subsurface testing of buried deposits as detailed in the geoarchaeological evaluation.

\section{SITE FUNCTION}

Figure 7-1 compares lithic reduction stage frequencies from bluff/terrace sites to those of floodplain sites. A higher frequency of cores and tested cobbles ( 9 percent, $n=110$ ) and primary flakes ( 20 percent, $n=251$ ) is found at terrace/bluff sites than at floodplain sites where cores and tested cobbles make up only 1.5 percent of the assemblage $(n=2)$ and primary flakes account for only 6 percent $(n=8)$. This difference suggests more-intense early stage lithic manufacturing activities of the types associated with procurement sites occurred at the elevated sites.

Figure 7-2 illustrates that features are not commonly found at sites with high frequencies of primary flakes, further supporting their classification as lithic procurement or location sites. Comparison of combined frequencies of lithic tools (bifaces, unifaces, and points) at terrace/bluff sites ( 3 percent, $\mathrm{n}=35$ ) versus floodplain sites ( 7 percent, $n=9$ ) suggests final-stage reduction activities were emphasized at the floodplain sites.

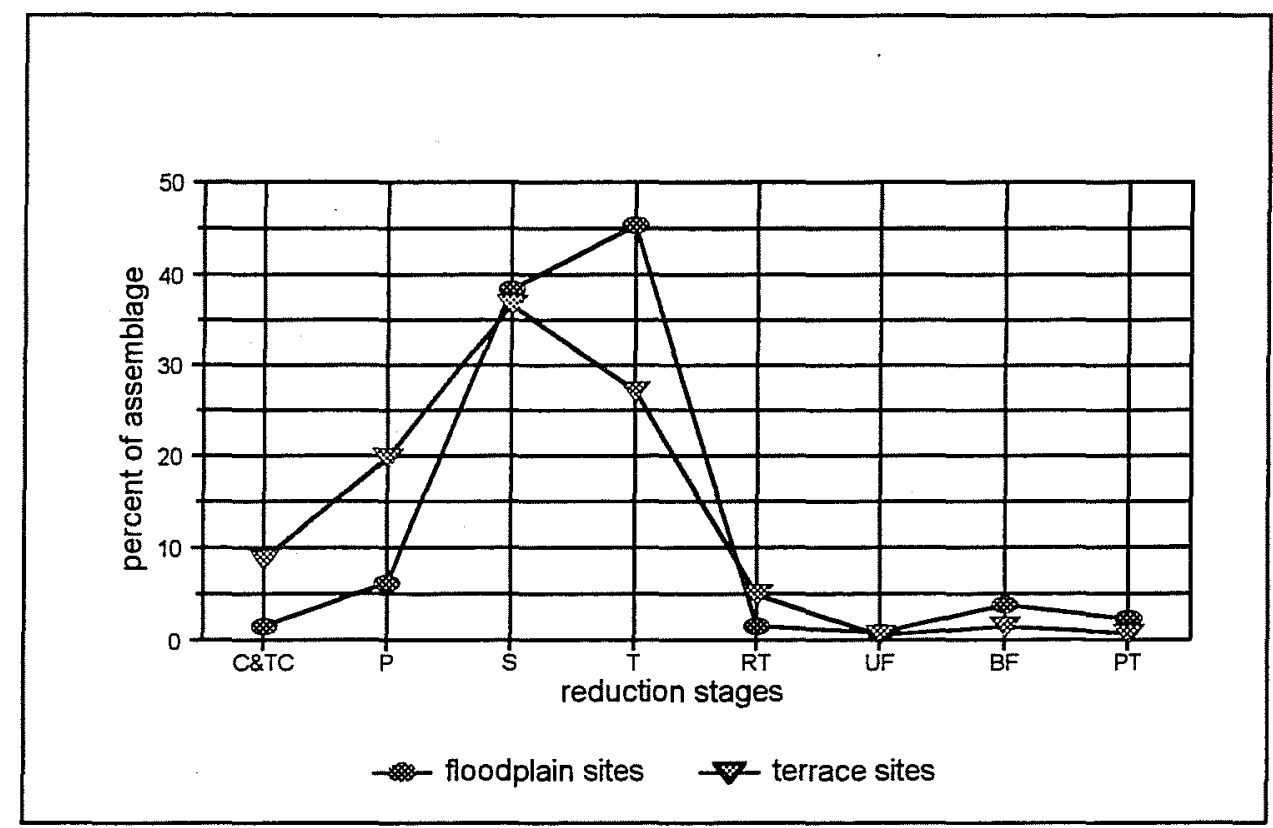

Figure 7-1. Reduction stage frequencies, floodplain vs. terrace sites. C\&TC: cores and tested cobbles; P: primary flakes; S: secondary flakes; T: tertiary flakes; RT: retouched flakes; UF: uniface; BF: biface; PT: projectile point. 


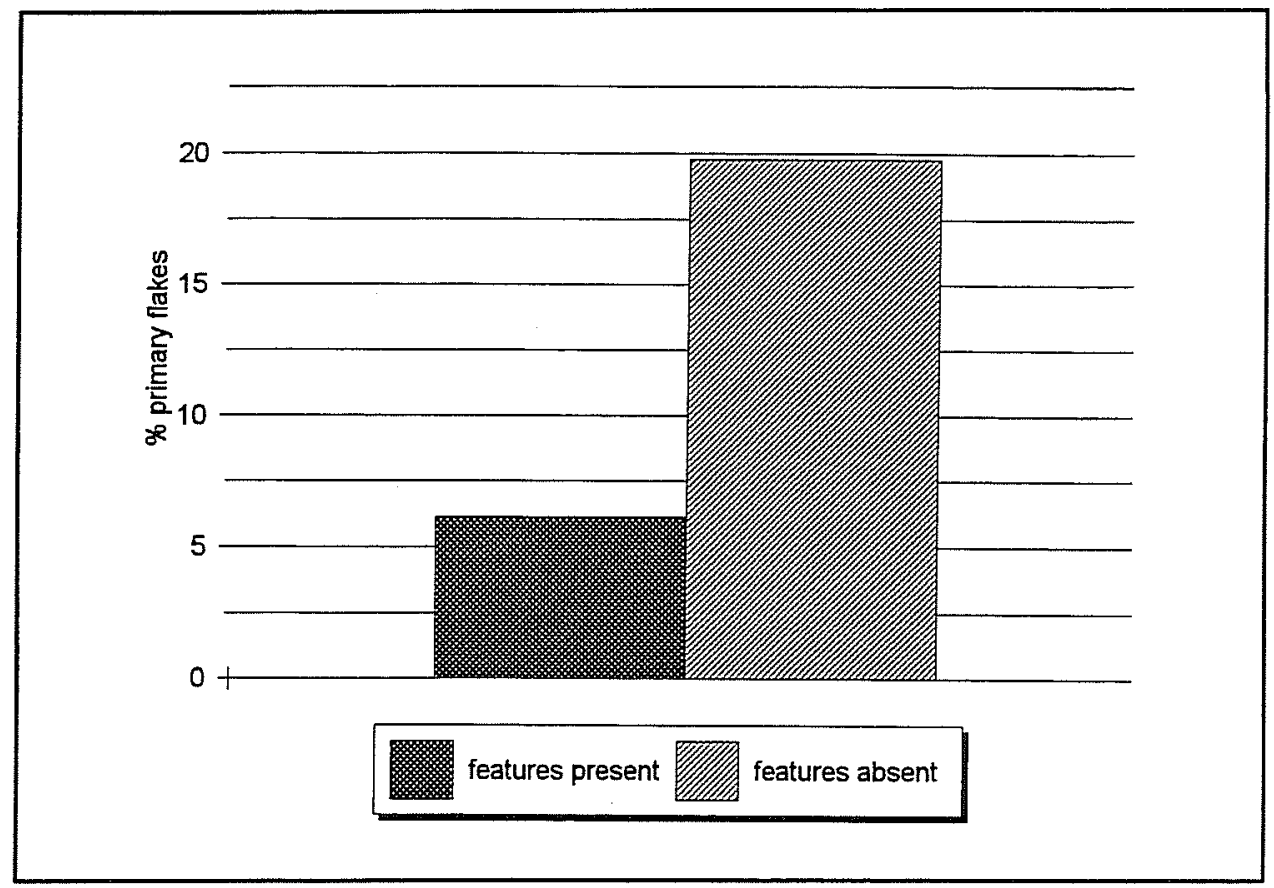

Figure 7-2. Primary flake and feature comparison.

Figure 7-2 indicates another characteristic of the bluff/terrace versus floodplain site content pattern: sites without features have a higher average proportion of primary flakes, and the sites with features have a higher proportion of late-stage reduction items. The presence of features coupled with late stage reduction activities fits the archaeological expectations for both residential bases and field camps which may be found in forager and collector systems (sensu Binford 1980). The bluff/ terrace sites with high proportion of cores, primary flakes, and low frequency of features suggest that these are primarily lithic procurement sites.

Note that site 41VV1654 covers an extensive area from the upper reaches of the west terrace (T2) down into the floodplain. The lithic sample from this site may represent discreet areas of activity (possibly of varying functions) and palimpsest effects. While differences in the degree of diversity of artifact types among the various sites are seen, the diversity increases with sample size. Without appropriate models (Kintigh 1984) to establish relationships between diversity and site function for the project area, the differences in the assemblages from Laughlin can not be used as measures of site function.

\section{SETTLEMENT PATTERNS}

Material correlates such as lithic assemblages and site characteristics are associated with differences in land-use patterns. Using a model of settlementsubsistence systems of hunters and gatherers, Binford (1980) posits that residentially mobile groups are generally associated with the employment of an expedient technology and fewer curated tools, with raw material availability being the primary factor in the organization of the lithic assemblage of foragers (Kelly 1988). Likewise, logistical strategies employed by collectors are generally linked to increases in curation and maintenance of tools (Binford 1977, 1980), with the duration and purpose(s) of the logistical forays affecting the composition of the tool kit (Kelly 1988). Binford (1979) suggests raw material procurement in logistical systems is embedded in basic subsistence tasks and schedules. The basis of these generalizations is derived from the concepts of the foragercollector continuum (Binford 1980; Kelly 1983) and the strategies used to relate raw material availability and technological efficiency to the temporal, spatial, and extractive demands of the resource structure. Of course, since most hunter-gatherer systems incorporate both residential and logistical components within their mobility system, the organization of the technological system is likewise compounded by the integration of expedient and curatorial components; 
thus the archaeological record is more complex. We originally suggested a foraging model for the Lower Pecos due to the resource structure of the region; therefore, using relatively high residential mobility with the abundance of chert material available in the Laughlin area, the expectation would be for a lithic assemblage organized around an expedient flake industry.

However, simplistic generalizations comprised of lithic systems typologies and correlations between lithic system typologies, the forager-collector continuum, and mobility fail to address many of the aspects of the organization of lithic technologies and their relationship to settlement/subsistence strategies. That mobility plays a significant role in the organization of lithic technology is generally accepted, but Kelly (1989:719) states that "there is no direct correlation between mobility and the organization of a technology." Kelly (1989:719) instead relates hunter-gather lithic technologies to "a set of conditions concerning tool needs and rawmaterial availability." The definition and discrimination of various sets of conditions concerning tool needs have been approached in several ways but remains problematic.

Further complicating the issue are discussions of the relationship between lithic organization and the general mobility continuum as opposed to the more specific definitions of logistical and residential mobility used for understanding forager-collector strategies. Parry and Kelly (1987) use data from the temperate zone of North America to demonstrate a general shift from curated lithic core technologies during the Paleoindian and Archaic periods to expedient core technologies that they associate with the first appearance of permanent villages. Parry and Kelly (1987:297) postulate "that increasingly expedient lithic technology is a logical consequence of decreased residential mobility." However, Parry and Kelly are relating the organization of technology to the general concept of the mobility continuum as opposed to mobility strategies of forager-collector systems. They further note the concomitant shift from resource acquisition economies of huntergatherers to mixed subsistence economies that use domesticates as a staple in the diet.

In examining the lithic technology of huntergatherers, Binford $(1973,1977,1979,1980)$ used an organizational-technological continuum ranging from expedient to curated. Bamforth (1986) points out that Binford's concept of curation extends beyond design, manufacture, transport, and use of tools to include their maintenance and recycling and criticizes Binford as linking this entire range of activities directly or solely to settlement organization. Bamforth (1986:40) argues that technological organization is not determined "at the level of overall systemic organization without reference to local conditions" (such as resource availability) and that a particular technological organization is not defined simply by the economic system.

Although researchers use the concept of curation in different ways, the various definitions cover a wide range of activities and tool characteristics. Curation includes design and manufacture in anticipation of a tool's use; tools that are versatile and designed for multipurpose use; transportation from location to location; design for extended use-life and maintenance through numerous uses; tools recycled for other uses when they are no longer suitable for their original purpose; and tools which are often cached for later use (Bamforth 1986; Bousman 1993). Parry and Kelly (1987:288) also associate curation with bifaces and other "formal" tools, standardized production techniques, and a high level of skill and effort in the production process. In contrast, expedient tools are minimally prepared prior to use and are generally used for a specific, immediate task and then discarded at the location of use. The form of expedient tools is characterized "by little alteration or secondary shaping" (Bousman 1993:69), and no functional distinction is made between tools and debitage (Parry and Kelly 1987) in an expedient flake industry.

Bleed (1986) approaches the analysis of variability in technological systems through the examination of engineering concepts of design efficiency relative to risk management in the context of the resource structure of forager-collector models. He describes reliable systems as those in which failure costs are high and thus justify higher costs (time and material) to insure that the tools will function when needed. Reliable systems are used for generally specialized, predictable, and repetitive hunting activities. Maintainable systems have generally low failure costs and thus employ tools that can easily be brought to a functional state; these systems are used for generalized activities with continuous need but unpredictable schedules. Maintainable tools are 
generally simpler than reliable tools. Bleed (1986) limits his analysis to hunting tools and posits that hunters in a foraging system would use maintainable tools for scattered but ubiquitous game, and collectors would employ a reliable lithic system to hunt specific large game or seasonally available game. Although curation is not a conceptual aspect of Bleed's approach, the design aspects and characteristics of reliable and maintainable systems as defined by Bleed (1986:739) overlap and cross-cut the curatorial characteristics of a lithic technology.

Bousman (1993) proposes that the concepts of reliability and maintainability are not limited to extractive hunting weapons but have application to all extractive tools (tools used to obtain food) as well as to all maintenance tools (tools used to make other tools or products). He merges Bleed's design concepts with Binford's expedient/curated distinction and argues that a tool can incorporate aspects of reliability, maintainability, and expediency. $\mathrm{He}$ proposes that hunter-gatherers employ different design goals for extractive and maintenance tools. Bousman (1993:76) uses ethnographic cases to demonstrate that some forager groups' extractive tools have a longer use-life than those of some collector groups, while their maintenance tools have a shorter use-life than those of the collectors. $\mathrm{He}$ uses foraging theory as the basis to argue that foragers are time minimizers and emphasize longer use life with extractive tools and stress shorter production time and less maintenance costs in their repair kits (Bousman 1993). Collectors, as resource maximizers, stress attributes of diversity, complexity, and reliability and intensive maintenance strategies in their tool repair kits in response to resource structures with limited temporal availability that is exploited in bulk.

Several major variables affect the organization of lithic technologies, thus simple correlations between curation-expediency and the foragercollector continuum are insufficient to explain the organization. The correlation of the numerous variables "lead to a more complex view of how function can be expressed in the composition of an assemblage" (Ammerman and Feldman 1974:610). As Kelly (1988:719) asserts, "tool production and use are not responsive to logistical and residential mobility per se." Although methodologies have been offered for the above approaches to lithic organization, the development and implementation of techniques for identifying, measuring, and quantifying many of the criteria remains problematic as does discriminating the behavioral and temporal aspects relative to the criteria. Thus the application of the above-discussed approaches, while conceptually promising, has been limited, especially in contexts other than those in which the approach was developed.

The lithic tools identified at Laughlin exhibit attributes and characteristics of curation, expediency, reliability, and maintainability. However, the sample size and the nature of the project do not provide the means to analyze the organization of the technological system such to make inferences as to the settlement/subsistence strategies.

Site distributional data do allow some inferences, particularly with regard to land-use patterns in the interior upland areas of the project area. This aspect of the prehistoric adaptation of the base area varied considerably from the archaeological expectations. Originally we suggested that the upland areas were being extensively utilized for the exploitation of succulent plants and the hunting of small animals.

As is readily apparent from Table 7-2, the data indicate extensive use of the creek zone (density 1:36), but not of the uplands (density 1:210). Furthermore, no sites were identified in the uplands, only isolates. Of course, in a semi-arid area such as the Lower Pecos, a concentration of occupation sites and activity areas near water is to be expected. However, previous investigations indicated that the upland areas would be exploited for the succulents and cacti, although Saunders (1986) documented an absence of burned rock middens and features in upland areas away from large streams, with a greater number of ephemeral sites in those areas. However, neither case was identified during our survey.

A comparison of the density of sites and isolates from Laughlin AFB to other upland areas is appropriate as a means of developing models for regional and systemic settlement and subsistence organization. However, the certain unique qualities of the Laughlin area must be considered to place comparisons in the proper context. Although a part of the Rio Grande drainage, the base is several miles from that river and, as previously mentioned, is characterized by flat lands to gently rolling hills. The three short gullies or arroyos dissecting the bluffs in 
Table 7-2. Density of Prehistoric Remains

\begin{tabular}{|l|c|c|c|c|c|c|}
\hline \multicolumn{1}{|c|}{ Zone } & $\begin{array}{c}\text { \# of } \\
\text { Acres }\end{array}$ & $\begin{array}{c}\text { \# of } \\
\text { Isolates }\end{array}$ & $\begin{array}{c}\text { Isolate } \\
\text { Density }\end{array}$ & $\begin{array}{c}\text { \# of } \\
\text { Sites }\end{array}$ & $\begin{array}{c}\text { Site } \\
\text { Density }\end{array}$ & $\begin{array}{c}\text { Total } \\
\text { Density }\end{array}$ \\
\hline Uplands & 1471 & 7 & $1: 210$ & 0 & 0 & $1: 210$ \\
\hline Creek Zone & 533 & 4 & $1: 133$ & 11 & $1: 48$ & $1: 36$ \\
\hline Subtotal & 2004 & 11 & $1: 182$ & 11 & $1: 182$ & $1: 91$ \\
\hline Developed & 851 & 0 & 0 & 1 & $1: 851$ & $1: 851$ \\
\hline Total & 2855 & 11 & $1: 260$ & 12 & $1: 238$ & $1: 124$ \\
\hline
\end{tabular}

the lower part of Sacatosa Creek are relatively shallow and the area does not offer the vertical transitions seen in the canyonlands. The upland area of the base is also conspicuous for its lack of cacti and other succulents such as agave and sotol, instead it is dominated by acacia and other thorny and woody scrub plants (see Chapter 2). Scattered isolates of agave, sotol, and opuntia are present but not as dense patches. The gentle topography, soil conditions, and modern land-use practices are no doubt related to the low population and distribution of the succulents and cacti. However, overgrazing and modern use normally results in the displacement of grasses by shrub invasion. The distribution of succulents should have been only marginally affected by modern practices.

While comparisons of the intensity of use of different areas can be made by site and isolate density, little data is available on upland areas as most research in the Lower Pecos has focused on the canyonlands. Therefore most models for the use of the uplands have been based on inferences drawn from the data derived from rockshelters, from open terrace sites along the major rivers, and from upland sites that border the canyons, and those models are largely untested. A few surveys have been undertaken that include upland areas such as Turpin's (1982) research at Seminole Canyon and at Devils River State Natural Area (DRSNA) (Turpin and Davis 1993), the Dughest project undertaken by GeoMarine (Peter et al. 1990), and Saunders's survey project of the Blue Hills and Hinds Ranch (1986). However, comparisons to the Laughlin area project are problematic due to differences in methodologies, site and isolate definitions, and the presentation of the data.

The most useful data for comparison to the Laughlin area is Saunders's (1986) comparative study of the upland areas at Hinds Ranch and the Blue Hills. Table 7-3 presents a summary of the density for the three areas.

Table 7-3. Artifact Density Comparisons

\begin{tabular}{|c|c|c|c|c|}
\hline Survey & $\begin{array}{c}\text { \# of Sites and } \\
\text { Isolates }\end{array}$ & Acreage & $\begin{array}{c}\text { Density } \\
\text { in acres }\end{array}$ & Source \\
\hline Hinds Ranch & 693 & 3648 & $1: 5$ & Saunders 1992 \\
\hline Blue Hills & 86 & 1024 & $1: 12$ & Saunders 1992 \\
\hline Laughlin uplands & 7 & 1471 & $1: 210$ & \\
\hline
\end{tabular}


The Hinds Ranch site density (1:5) provides a baseline that includes a wide range of activities carried out in the upland areas near major rockshelters along the rivers of the canyonlands. The uplands of the Blue Hills are not associated with a water source and the topography of rolling hills is similar to the Laughlin project area. However, there is a striking difference in the site and isolate density of the two areas with a Blue Hills ratio of $1: 12$, compared to the Laughlin upland ratio of 1:210. A total of 184 tools, including 61 projectile points and 20 formal bifaces, was recovered from the BlueHills area. Only 7 isolates were recorded on the 1,471 upland acres at Laughlin; 3 tools were among the 9 artifacts recovered.

Based on the percentage of isolate point locations and the points in the total lithic assemblage, Saunders posits that the uplands at Blue Hills were used for hunting. Although succulents were present, he suggests that they were not intensively exploited at Blue Hills. Further, Saunders found no evidence of residential camps or middens, which suggests that the hunting was accomplished through a logistical strategy or that the area was within the range of daily foraging activities from residential or location sites away from Blue Hills. Although the succulent plant resources were available, the uplands did not have the facilities (water) to process bulk resources for transport to residential camps. Saunders, however, discusses how an upland area devoid of water and shelters is used, but the Blue Hills do not suffer from a lack of evidence that the area was exploited, whereas there is a dearth of evidence that the Laughlin upland zone was exploited for either hunting or succulent gathering.

The other surveys mentioned above identified several types of sites in the upland zones; however, most of these are upland areas that border canyons. Lithic scatters, quarries, burned rock middens, ring middens, stone alignments, hearth fields, and pictograph sites have been found in the uplands, but only a few sites have been identified in the interior areas away from the permanent rivers and lower canyons.

As previously stated, none of the above types of upland sites is found in the Laughlin upland zone, and only a few isolated lithic artifacts were identified. If hunting activities occurred in the uplands, isolate projectile points would be expected as seen at Blue Hills; however, a comparison of the artifact and site density indicates little hunting activity at Laughlin. If collecting and processing of succulents occurred, ring middens and either curated bifaces or worked flakes or unifaces would be expected, but again the archaeological data provides no evidence that these activities occurred.

The hearths and possible hearth remnants at the five sites on the east terrace of Sacatosa Creek could represent residential bases or locations associated with a forager system, or field or base camps (41VV1688) in the collector component of a mobility system. Approximately 4.8 to $6.4 \mathrm{~km}$ northwest of the base, 15 sites along the banks of San Felipe Creek in terrain similar to that at Laughlin were identified (Dibble 1974; Prewitt and Dibble 1974). Hearths, burned rock middens, and middens as deep as $60 \mathrm{~cm}$ were found, as were manos and numerous points and bifacial tools. A comparison to these sites indicates a more narrow range of activities and shorter or less repetitious occupation at Laughlin. However, only limited investigation of these sites was undertaken within the purview of the objectives of the survey. Further definition and function of these sites and their role in the settlement/subsistence system could be addressed with further research.

\section{EXPLANATIONS FOR THE LACK OF USE OF THE LAUGHLIN UPLAND ZONE}

That a paucity of material was observed in the upland hills and flats at Laughlin is clear, and several plausible explanations exist. Most of the possibilities revolve around the research methodology or postdepositional processes.

First, there is the possibility that the 20 -m transect spacing did not provide the necessary coverage in an area with low artifact density. The $20-\mathrm{m}$ spacing was effective in the creek zone that had similar or less ground visibility, but if the difference in the results is a function of artifact density, then the possibility exists that the artifacts were not observed in the uplands due to the transect spacing. However, given the relatively good ground visibility and the experience level of the crews, this possibility seems remote.

Another factor that may have affected the results is the possibility of buried material. About 368 of the 
1,471 acres of the uplands were identified by Nordt as valley fills with about $50 \mathrm{~cm}$ of sediments and soils of Holocene age. Thus buried material may occur in the valley fills as a result of postdepositional processes. If so, a systematic method of subsurface testing, such as shovel tests, would reveal the material. However, the possibility of buried material is mitigated by the lack of material throughout the uplands. If there was a drop-off in the density of artifacts in the areas of the valley fills, then there would be reason to suspect that postdepositional processes were the cause and further investigation would be required.

Another consideration is the differential use of the uplands and the creek zones for military operations. Although the differences in use are difficult to quantify, much of the upland area was routinely subjected to heavy human and equipment traffic, whereas much of the creek zone was fenced and seldom affected by military operations. Some of this creek-zone acreage was, however, leased to ranchers and was thus subjected to goat and cattle grazing. No doubt the area has been affected and artifact scavenging has occurred, but the degree of the effect of military operations is difficult to assess. Since points were recovered at the base and the base historian reports collecting activities over the years, it is reasonable to suggest that collecting has reduced the number of points remaining in the uplands. However, many researchers associate unifaces with the exploitation of succulents and there is no reason to expect that these type of tools or debitage would have been removed by local collectors.

Another line of reasoning to explain the lack of evidence for the use of the uplands is that those areas were exploited only minimally and thus the very low frequency of artifacts observed is representative of minimal use. The modern microenvironmental habitat contains only sparse amounts of the succulents and cacti that has been documented as major components of the Lower Pecos diet. Thus if the current floral condition is representative of the prehistoric uplands microenvironment, it follows that the Laughlin upland area was not extensively exploited because it did not contain needed staple resources. Presumably the seed resources and small game in the uplands were either not exploited or these activities left little archaeological evidence.
Most models for the use of uplands propose either foraging from a residential base and transporting the succulent resources back to the camp, or roasting facilities in the uplands in association with temporary camps. However, in the area at Laughlin, the data do not support either of the models. The data suggests a linear exploitation of the area tied to the streams with exploitation of the riverine and terrace resources.

Our analysis indicates that the bluff/terrace sites were used as lithic procurement areas during the Late Paleoindian and Early Archaic periods and the absence of hearths or other features give little indication that the bluff/terrace zone was used for habitation. The geomorphological evidence indicates that early sites in the floodplain may be buried, and thus the floodplain was utilized during the entire span of the area's exploitation. However, the lack of evidence of lithic procurement activities during the Middle and Late Archaic or Late Prehistoric periods on bluffs and terraces may indicate a shift in land-use patterns.

Models of settlement/subsistence systems for this area should consider 1) its location on the periphery of the canyonlands, 2) the effect of the local resource structure and topography on those systems, and 3) how the Laughlin area articulates with the canyoniands. As Saunders (1986) states, while much is known about the use of the major river systems and the major canyonlands, little systematic research has been accomplished in the uplands, thus precluding an understanding of the systemic use of the Lower Pecos region and the role of the interior uplands in the regional settlement/subsistence system. 


\title{
Chapter 8. Historic Period Background
}

\author{
Shirley Boteler Mock
}

\section{INTRODUCTION}

This chapter begins with an overview of previous archival and archaeological work in south Texas. From these sources, a broad cultural context is developed and presented chronologically. The next section, detailing sheep ranching in south Texas, is followed by a discussion of the Zacatosa Ranch which was located on what is now Laughlin AFB property. The information presented in the latter results from CAR's archival research and personal interviews. The final section outlines the history of Laughlin AFB.

\section{PREVIOUS RESEARCH}

The lifestyles, culture, and ethnic groupings of the historic Indians who lived in the Lower Pecos region are little understood (Hester 1989c:77). Several Historic Indian groups such as the Coalhuilteco, Lipan Apache, Toboso, and Comanche have been recorded in the Lower Pecos area. A number of researchers in the 1950 s and early 1960 s attempted to compile a summary of the culture of the Indians of south Texas and northern Mexico (Ruecking 1953, 1954a, 1954b, 1955; Schuetz 1969; Troike 1961, 1962); these attempts are summarized by Almaraz (1979). Other researchers have attempted to define food sources and processing methods for these same peoples (León et al. 1961; Salinas 1990). Campbell (1972, 1979, 1991), Ewers (1973), and Newcomb (1961) contributed data gleaned from the reports of early contact by Europeans with the indigenous peoples. Faulk (1969) and Herring (1986) address the later Historic period in light of intrusive peoples such as the Apache and the Comanche. The intrusion of these later groups brought about cultural changes in the post-contact period (De Vore 1993; Hester et al. 1989).

Steen (1948) describes contact between Indians and Europeans in south Texas. De Sosa's expedition into the Del Rio area is recounted by Bannon (1963) and John (1975). Numerous other sporadic Spanish expeditions are chronicled by Fox (1989), Hammond and Rey (1967), and John (1975). Clark et al. (1964) and Fox (1989) describe the introduction of the mission system into this portion of the Rio Grande area. The first Franciscan concerns with the area in 1675 are addressed by Bolton (1959).

Oberste (1953) relates the problems of the new Mexican government toward the unsettled and unpopulated frontier created by the introduction of colonization and the empresario system. The development and maintenance of Spanish-Mexican ranching is described by Fox (1989).

Frequent encounters with Indians following the Mexican War necessitated the U.S. military's presence on the frontier (Clark et al. 1964; Webb 1952). Specific information on the individual forts and camps established at this period are provided in Bowden (1986) and Wooster (1987). Daily military operations are addressed by Labadie (1994:1-4). The importance of ranching, both sheep and cattle, to the economy of southwest Texas has been documented by Hester et al. (1989), while the Spanish origin of these traditions is discussed by Fox (1989). The significance of the growth of the sheep industry and improved access provided by the introduction of rail transportation created new markets which had a major impact on both the area's and the state's economies (Briggs 1974; Carlson 1982; Cronon 1991; Labadie 1994; Lehmann 1969; Patterson 1980; Texas Almanac 1933). Specific economic contributions by early settlers are chronicled by the Whitehead Memorial Museum and the Val Verde Historical Commission (WMM/VVCHC [1976]).

A flurry of archaeological work in the 1960s was initiated by the construction of the Amistad Reservoir. Pre-inundation studies of prehistoric and historic sites include those of Briggs (1974) and Parsons (1962). Historic sites related to the railroad were noted within the boundaries of the Seminole Canyon State Historical Park (Briggs 1974; Patterson 
1980) and near Langtry (Patterson 1987). To the west of the Southern Pacific Railroad bridge are tunnels that were placed on the National Register (Labadie 1994). One late-nineteenth-century pictograph (41VV226) created by a Southern Pacific employee has been recorded.

\section{CULTURAL CONTEXT}

Archival as well as archaeological research has documented the dynamics of indigenous and European peoples in the Lower Pecos region of southwest Texas. Drawn by the sparkling waters of San Felipe Springs, a succession of visitors from early Paleoindians (circa 11,950 B.P.) to later sixteenth-century Spanish explorers such as Cabeza de Vaca and Castano de Sosa were drawn to this historic landscape near the present-day town of Del Rio. In marked contrast to other areas of Texas, this borderland area remained virtually untouched by the political activities of Spain, Mexico, and the United States during the early part of the nineteenth century.

\section{OVERVIEW OF HISTORIC INDIANS}

In recent papers, Campbell (1972, 1979, 1991) points out the fallacy of lumping together a large number of small historic ethnic groups in Texas which were in the process of rapid change at the time of contact with the Spanish. He stresses the absolute necessity for the researcher to obtain every possible document which might include a description of individual groups and how and where they were living at the time of encounter. Campbell, following his own advice, has completed years of painstaking research, resulting in a large body of information on the Indian groups of the south Texas and northern Mexico area (e.g. Campbell 1991; Campbell and Campbell 1981, 1988). Particularly pertinent to the Del Rio area is Campbell's (1979) publication on the Indian groups connected with three eighteenthcentury missions at present-day Guerrero, Coahuila, approximately $48 \mathrm{~km}$ downstream from Eagle Pass/ Piedras Negras. From Campbell's examination of each group and their distribution and living habits, an interesting pattern emerges of the Bacorame, Cohabita, Ervipiame, Gueiquesal, Hape, Pacuache, and Saesse, who inhabited the general area of northeastern Coahuila, across the Rio Grande from
Del Rio between the mountains and the river. These people habitually crossed the Rio Grande below the mouth of the Pecos to hunt bison in the winter (Campbell 1979), ranging northward as far as the southern margin of the Edwards Plateau.

These indigenous groups were pushed into northern Mexico by the Lipan Apaches who moved into Texas from Colorado and New Mexico in the 1600s-1700s (Hester 1989c). By 1729 the Lipan Apache were the dominant group in the Lower Pecos region, but they too were soon pushed into Mexico by the Comanche (Weddle 1968). Both Indian groups created havoc in the lower Rio Grande area with the Comanche not only harassing the Apache, but raiding the Spanish settlements as well (Hester 1989c:83-84). Other Plains and Southwestern groups such as the Kiowa, the Kiowa-Apache, and the Mescalero were also present on the Texas plains but had no significant impact on the Lower Pecos area.

This vast expanse of land belonging to the Indians was perceived as unoccupied space to be expropriated by more civilized sedentary peoples. As one recorder of history proclaims, the lands were to be put to a more useful purpose than serving the needs of "roving Indian tribes," that of the "production of meat and feed crops for a great and civilized nation" (Jones 1927:95).

Distinctive archaeological remains of the Historic period Native Americans in the Lower Pecos is limited to scattered metal arrow points, one rockshelter, and 16 rock art sites incorporating mission, crosses, men on horseback, and cattle (Hester 1989c; Turpin 1989, 1995).

\section{SPANISH-MEXICAN PRESENCE (1700-1836)}

Spanish expansion of the northeastern frontier progressed slowly toward the Rio Grande until the late-seventeenth century (Bannon 1963; John 1975:33-36). Certainly the hesitance to settle the area was due in part to the presence of some Indian groups hostile to Spanish intrusion on their hunting lands. De Sosa's reports of encounters with the Tepelguan, a group of nomadic bison hunters originally from the southern plains of Texas (De Vore 1993:9) and de Vaca's eyewitness descriptions (de Vaca 1984[1527]) are some of the earliest historic accounts. Contact with the Indian populations 
in the area, though sporadic, continued into the seventeenth century with the intrusion of the Spanish entradas such as the Expejo-Beltran expedition and the Bosque-Larios expedition (Hammond and Rey 1967).

In documenting their journeys, however, many of the Spanish explorers were more concerned with conquering territories laden with riches than with describing the ecology of the lands they visited (Inglis 1964:4). They found the aridity and brushcovered lands of the Lower Pecos area unsuitable for settlement, traveling on in their relentless search for riches and converts. Archaeological information indicates that prior to Spanish contact, indigenous groups in the Lower Pecos region practiced a hunting and gathering way of life utilizing such wild plant resources as maguey or sotol, prickly pear tuna, acorns, roots, wild plants, and mesquite, and a variety of animals such as deer, rabbits, javelina, rodents, birds, and fish (e.g. Campbell 1991:344; Salinas 1990).

Early Franciscan expeditions into east Texas tended to stay well south of the Del Rio area, crossing at several fords near Guerrero (Bolton 1959:291; Campbell 1979). The arrival in Coahuila of a new group of Franciscan missionaries from the College of Queretaro gave impetus to the process of settlement and resulted in the founding, in 1690, of a group of missions in east Texas (Almaraz 1979:1). In order to support the missionary effort in south Texas, it soon became apparent that a way station at the Rio Grande crossing was necessary and, by 1701 , a settlement containing two missions and a presidio had been founded in the Valley of the Circumcision, downriver from present-day Piedras Negras. The presidio served a dual purpose in guarding the mission from attack by Indian groups, and providing troops to escort travelers. Two seasons of archaeological excavations at this location in 1975-1976 resulted in a series of publications (Almaraz 1979, 1980; Campbell 1979) and two unpublished reports (Adams 1975,1976 ), which contain the only archaeological information available on Spanish settlement in the central portion of the Rio Grande between the Big Bend and Laredo. Actual physical presence of the Spanish in the Lower Pecos region is limited to the unsuccessful 1737 attempt to establish the Sacramento presidio on the San Diego River south of Ciudad Acuna (Moorhead 1975) and the short-lived mission San Felipe Del Rio established near Del Rio in 1808 (Clark et al. 1964).

By the early part of the nineteenth century, a shortlived community had been established in an area called "Las Sapas" or "El Salto" (WMM/VVCHC 1976:3), located on the San Felipe River where it empties into the Rio Grande northwest of Del Rio. The small community was actually a transitory stepping-stone for Mexicans who were on their way to other communities in Texas. The homes of these early inhabitants consisted of makeshift underground shelters covered with brush or grass (WMM/ VVCHC 1976:3). By around 1870, the transitory community was eclipsed by the development of large haciendas needing farm laborers (WMM/VVCHC 1976:5).

In 1821 Mexico achieved independence from Spain and became concerned with finding settlers to bolster and protect its claims to Texas from usurpers. The Mexican government encouraged empresarios to bring new immigrants to the area by rewarding 23,000 acres for each 100 families successfully settled on land grants (Oberste 1953:2-3).

The tradition of ranching, brought over by the Spanish and continued by the Mexican government, continued through the 1840 s. Ranches, such as Villa de Dolores on Los Morales Creek in Kinney County, were established, but were later disbanded due to drought, Indian raids, and the presence of Santa Anna's troops in the region (Fox 1989:88). Hastily constructed forts were built in response to the Mexican War which ended with the signing of the Treaty of Guadalupe Hidalgo on February 2, 1848. As a result, Mexico renounced all claims to Texas and accepted the Rio Grande as the boundary between the U.S. and Mexico (Webb 1952:185). During the Texas Republic period (1836-1846), Anglo-American settlement expanded further west into the unsettled range lands of the broad Rio Grande plain, setting the stage for large scale cattle ranching as a major economic base in this region.

In 1845 the Texas Republic began issuing land grants to individuals such as homesteaders or former soldiers in the war for Texas independence (WMM/ VVCHC 1976:466). Among early Anglo-American land owners in the area was Erastus (Deaf) Smith, a hero of the war of Texas Independence who was awarded a large parcel of land (No. 153) at the 
confluence of San Felipe Creek and the Rio Grande in 1850 (Figure 8-1). Under the Texas Republic, the tradi-tional Spanish-Mexican system of land grants or porciones gave way to the use of "long-lots." The latter was usually a narrow, perpendicular ribbon of land stretching from a road, navigable river, or irrigation or drainage ditch (acequia). Long-lots typically varied in size from small lots of 4 hectares (10 acres) to larger grants measuring $8 \times 32 \mathrm{~km}$. At a minimum they were three times as deep as wide, however the majority of Texas long-lots exceed these dimensions in depth (Jordan 1974:71). Typically, long-lot plots occurred in groups rather than singly, thus allowing this form to dominate entire river valleys (Jordan 1974) as seen in the Del Rio area.

Settlers along the Rio Grande and its right bank tributaries generally received larger porciones due to the nonirrigable land. The most valuable long-lots granted by the new Texas Republic were those aligned in a northeasterly direction along the Rio Grande (Figure 8-1). Most of these land holdings measured $1.1 \mathrm{~km}$ wide and $16 \mathrm{~km}$ in depth. The peculiar shape of the lots was due to the need to provide access to water for livestock for, according to documents, no provision was made for irrigation, creating many future legal entanglements in Texas (Jordan 1974:74). Additional problems occurred later since access to water was often threatened when the plots of land were divided among heirs; thus, the value of certain portions of the property were diminished if, in the process of division, they were cut off from the Rio Grande (Maupin 1974:105).

Statehood, achieved in 1846, encouraged the advance of settlers, until the Civil War disrupted the region. In 1885, Val Verde County, population 1,800, was created out of portions of Kinney, Crockett, and Pecos counties (Clark et al. 1964:2; Hester et al. 1989:126). The town of Del Rio, which had been laid out nine years earlier, became the county seat.

\section{DEL RIO: THE FRONTIER OASIS}

The historic frontier was a late and transitory development in Texas history, the borders constantly changing with each influx of immigrants and advance of technology. As each new wave of immigrants followed the golden path of opportunity, the frontier was extended further southwest. Frontier communities such as San Antonio became economic centers while small settlements such as Del Rio, located near the confluence of the Rio Grande and the Devils River, sprang up on the frontier fringes. By the turn of the twentieth century, this small community became the nucleus for a coterie of enterprising sheep ranchers and claimed its place as one of the nation's largest producers and warehousers of wool and mohair. Del Rio was an integral part of the regional and state economy until the invention of synthetic fibers in the 1950 s and 1960s (Carlson 1982:213).

From the very beginning, Del Rio's supply of pure sparkling water from its three springs ordained its survival (Jones 1927:12). In an arid environment such as southwest Texas, water sources, in particular irrigation systems, played a significant role not only in the settlement but the evolution of social and cultural patterns. Determined to transform this arid area into the "Land of Promise," six entrepreneurs embarked on designing and constructing an elaborate irrigation system of irrigation canals or acequias extending from Del Rio south to the Rio Grande (WMM/VVCHC 1976:467).

In 1868, following the Civil War, a joint stock company was formed by James $\mathrm{H}$. Taylor of Uvalde; Joseph Ney of D'Hanis; Donald Jackson, a surgeon in the U.S. Army stationed at Fort Clark; A. O. Strickland and Randolph Pafford of Kinney County; and W. C. Adams of San Antonio. The explicit purpose of the company was to purchase the Mitchell grant (Lot 183), awarded to the heirs of Dr. James Mitchell who was killed at the Battle of San Jacinto in 1862, and other properties below and to the southwest of Del Rio to construct an irrigation system to increase the value of the land (WMM/ VVCHC 1976:467). Jerome Strickland later joined these "six stout-hearted pioneers"-later to be known as the fathers of Del Rio (Daniels 1922:52)-and shareholders in the Madre Ditch (Acequia Madre) of the San Felipe Agricultural Company (WMM/ VVCHC 1976:468). Unfortunately, Jackson and Strickland were killed by Indians and did not live to see the fruit of their labors (WMM/VVCHC 1976: 469)-the first irrigation ditch on the west bank of the San Felipe River completed in 1871.

Controlling interest in the irrigation company was secured by $\mathrm{G}$. Bedell Moore, who also acquired title to the Sosteno Corrosco survey on which the San Felipe Springs were located (WMM/VVCHC 1976: 


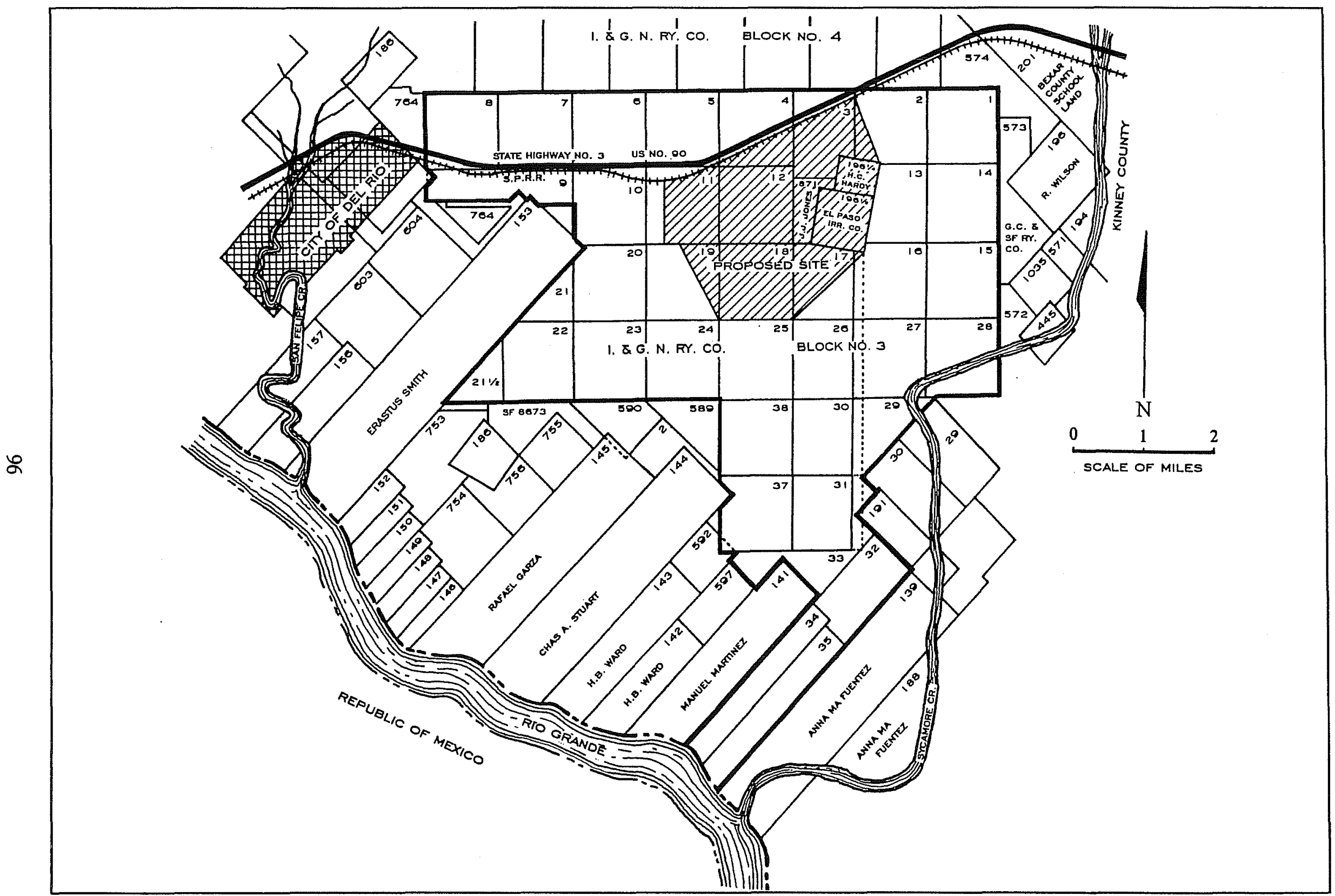

Figure 8-1. Map of the proposed Air Corps Training Center, 1940. Laughlin AFB archives. 
184, 475). This irrigation project later became the San Felipe, Agricultural, Manufacturing, and Irrigation Company (S.F.A.M.\&I.) (Daniels 1922: 52), 45 miles of canals creating an oasis of rich farmland of oats, corn, sugar cane, and other crops in what is today Del Rio.

Water, now made available by an extensive irrigation system, thus became a dynamic force in the changing landscape, creating a context for accelerated economic development and settlement. Staple crops such as corn and oats grown by small farmers were sold to prairie schooners plying the trails between San Antonio and El Paso and further to Chihuahua City, thus opening up a new mercantile economy in Del Rio, by now incorporated into Kinney County.

Additional advantages accrued were farm-related jobs for Mexicans and Mexican-Americans. Among the 145 residents of San Felipe listed in the 1870 census, 41 of 47 male Mexican nationals listed their occupation as farm laborer. Among the Mexican nationals, three are listed as sheep herders while one is listed as a farmer (WMM/VVCHC 1976:14-17). For example, among the settlers to Del Rio with Hispanic surnames in the 1860 s was Esteban Salvatierra. By 1900 he and his wife, Trinidad, and family had a farm on the Rio Grande west of Del Rio (WMM/VVCHC 1976:8).

Not to be overlooked in the story of the creation of an oasis economy in Del Rio is Doña Paula Losoya Taylor de Rivera (Figure 8-2), wife of the sixth father of Del Rio, the James Taylor noted above. Doña Paula played an integral role in the evolution of Del Rio into a growing community by the latetwentieth century. Arriving from Rio Grande City, Texas, in 1862 with her sister, Doña Refugio Losoya de Rivera, she subsequently married James A. Taylor and the couple requested and received a government grant on which they built a home and started farming. According to documents (Valdez 1976:3, 5), after the death of James, Doña Paula and her sister became powerful and influential forces in the small settlement of San Felipe; their hacienda the center of politics and religious activities (WMM/ VVCHC 1976:3). Doña Paula, moreover, became actively involved in the construction of the first irrigation ditch or Acequia Madre and, after its completion, started a sugar cane mill, a candy factory, a flour mill, and a gin, ultimately becoming an immensely wealthy woman. According to the same document, Doña Paula was responsible for asking the commander of Fort Clark at Las Moras to send a detachment of soldiers to drive out the Indians, who were constantly attacking the San Felipe settlement. It is said that Doña Paula buried three Indians and two Mexicans on her property on Round Mountain (Valdez 1976).

\section{PROTECTING THE HINTERLAND: MILITARY PRESENCE IN THE LOWER PECOS}

The U.S. Army was dependent on a network of roads for the maintenance of its strong, significant frontier presence in Texas from about 1848 until 1890. The military presence was characterized by a constantly changing array of forts, subposts, and small temporary camps rather than a line of static defensive positions (Wooster 1987).

Because of its strategic location, San Antonio became the hub of the regional fort system as it could readily supply all western garrisons with both men and provisions. By 1848 construction of a military road from San Antonio westward began, followed by the routing of wagon trains through the area (Clark et al. 1964:2).

The U.S. Army constructed a series of roads and two interrelated chains of forts in endangered frontier areas (Figure 8-3). The first chain paralleled the U.S.-Mexican border, extending from Fort Brown at the mouth of the Rio Grande, to Fort Duncan in Eagle Pass. The forts were situated to impede access to traditional Indian fords, but they were primarily intended to serve as a means for protection of the international border. Fort Clark, founded in 1852 at the head of San Moras Creek in Kinney County, was the first of a series of forts dedicated to guarding the roads.

From Camp Hudson and Forts Brown, McIntosh, Duncan and Clark, the U.S. Army would launch punitive operations against Indians, in addition to performing routine patrols. Much of the army's daily operations, in fact, involved protecting the roads and providing escorts for mail carriers, freighters, cattle drivers, and wagon trains (Labadie 1994:2-17). This early military presence in west Texas was ultimately responsible for the development of the ranching 


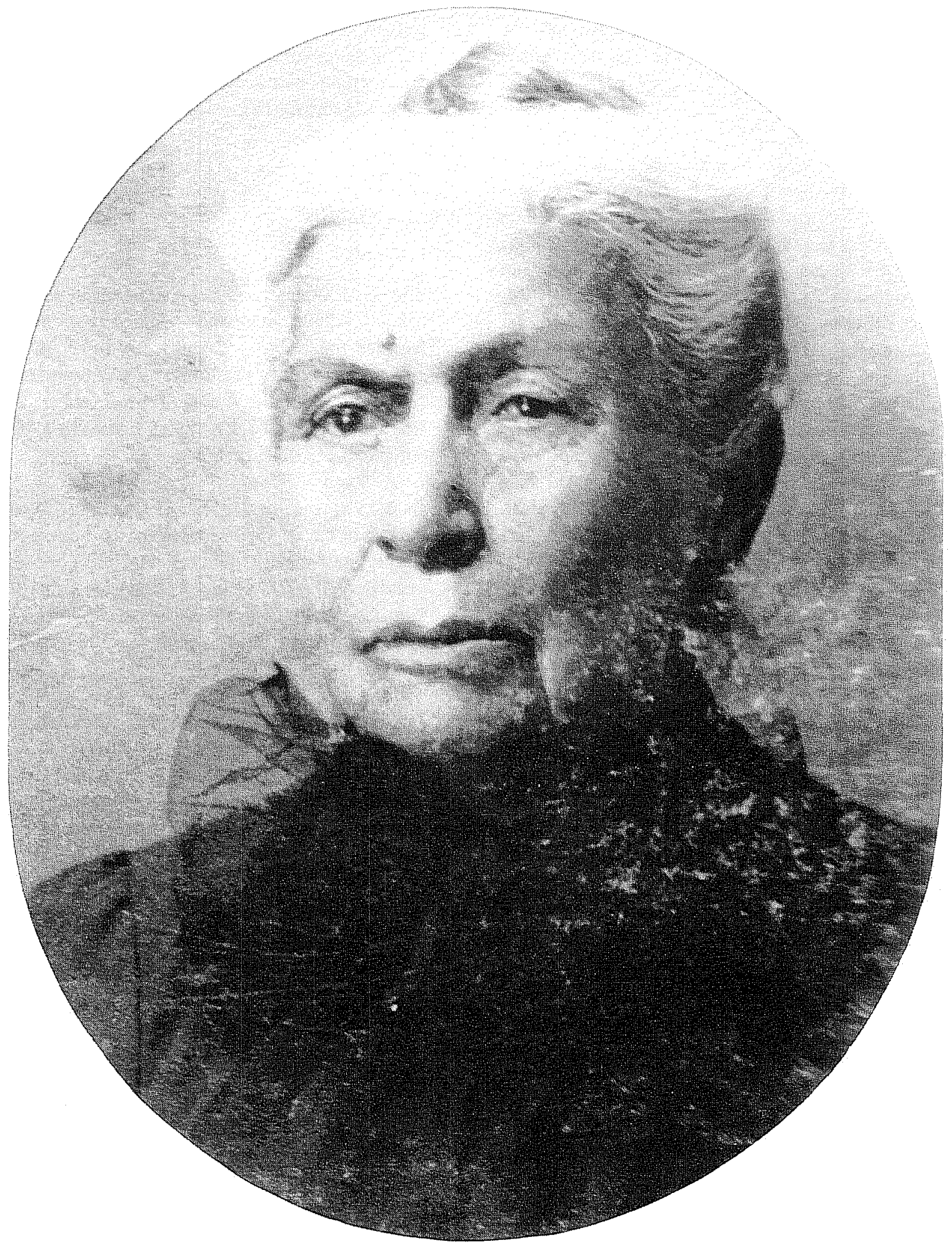

Figure 8-2. Portrait of Dona Paula Losoya Taylor de Rivera. Whitehead Memorial Museum. 
economy that later flourished in Del Rio and Val Verde County. The second chain of forts extended from Fort Worth to Fredericksburg (Fort Martin Scott) and was designed to be slightly in advance of the expanding western frontier (Figure 8-3).

The frontier had advanced beyond the fortification system by 1852 . A new line of forts was then constructed about $240 \mathrm{~km}$ farther west. Finally, the discovery of gold in California necessitated a third chain of forts spaced at irregular intervals along the El Paso-San Antonio road/trail (Bowden 1986:1-2).

During the Civil War, all of Texas's borderland forts were surrendered and troops evacuated. Both Fort
Clark at Brackettville and Fort Duncan in Eagle Pass were abandoned in 1861 (Bowden 1986:15-8). Attempts to protect the western territories from Indians, however, continued into the 1860 s with Fort Clark reactivated in 1866 due to the continued demand of the ranchers for protection (Brown 1976:429). An outpost was built in 1857 on San Felipe Creek, which became known as Camp Del Rio (Clark et al. 1964:2), and made a sub-post of Fort Duncan. It was closed 10 years later, and only briefly re-opened from 1914 to 1922 . Continued threats from Indians and rustlers and the desolate nature of the land created a vast "high risk" arena of territory awaiting the first forays of immigrant entrepreneurs.

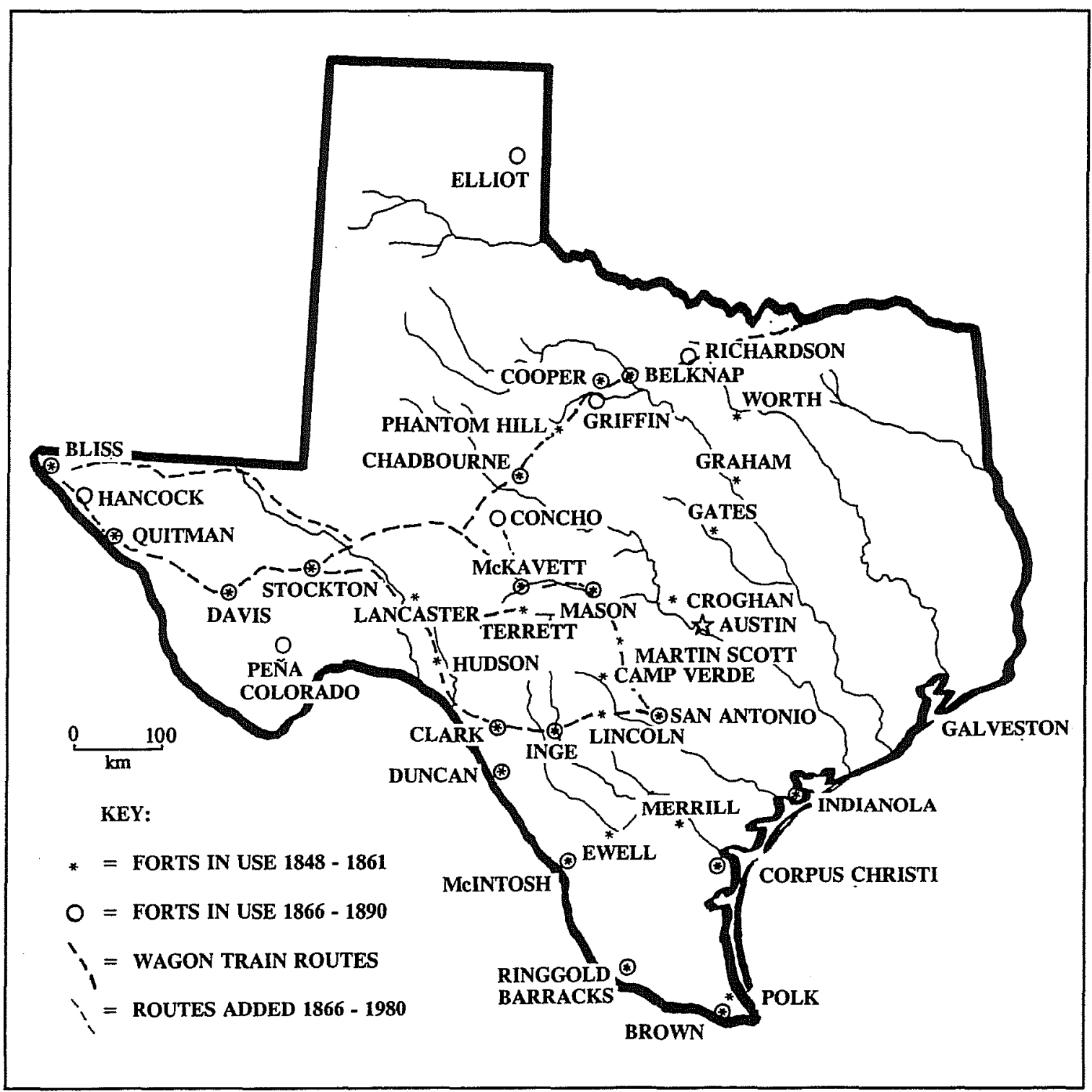

Figure 8-3. Texas frontier forts and roads. 
After the Civil War, the federal government decided not to re-occupy all the forts that were originally part of the 1850 borderlands line of defenses. Instead, a new series of forts further west was opened (Labadie 1994). In the 1880 s and 1890 s, having eliminated the threat of Indian attacks, the U.S. Army gradually abandoned its Texas posts (Wooster 1987).

\section{THE RISE OF THE HINTERLAND: THE RAILROADS}

The frontier expanded as cities such as San Antonio became economic centers, and tributary settlements such as Del Rio sprang up further west. Metropolises and outlying tributaries became inextricably connected in a relationship of economic dominance and dependency due to a combination of environmental, political, and economic factors and the values of the societies that shaped them. This changing landscape, fueled by new episodes of technological innovations, is the historic context of the Lower Pecos region.

Attempts to draw this area of Texas into the heartland of America were accelerated by a momentous occasion near the Pecos River on January 12, 1883: the joining of the Texas and Pacific Railroad and the Southern Pacific Railroad with a silver spike (WMM/VVCHC 1976:109). Not only did the railroad open up the frontier to immigrants and provide access to other technologies, but it also afforded a continuous exchange of information from more urban areas or cities, both making accessible and reinforcing the values and attitudes of mainstream America (e.g. Hardesty 1985:214). Another technological innovation, the telegraph, also spread quickly throughout the southwestern Texas frontier playing a prominent role in the standardization of the frontier. Widespread advertisements by the railroad companies and the Texas Land Office (Kupper 1921) actively solicited prospective investors and land owners. The railroad, in particular, was anxious to sell large holdings of land and to generate traffic by encouraging settlements along their rights-of-way. Advertisements by land speculators, authors, agents for immigrant associations, and publications such as the Texas Almanac perpetuated the image of southwest Texas as a pastoral landscape, combining both wilderness and garden (Doughty 1986:105). Such images included a glowing description of the small town of Del Rio as the "blending of the rugged with the beautiful ... We have in the combination, a valley decked with flowers and bubbling springs, surrounded by the eternal sentinels, the hills" (York 1922:25).

In 1890 an auction of town lots in east Del Rio was advertised to lure prospective settlers (Figure 8-4). The country around Del Rio is described as "the finest in the Southwest, and that portion is certainly the Virginia of the Lone Star State for water as pure as any country" (WMM/VVCHC 1976:23).

As the railroad survey was completed through Del Rio in preparation for construction of a section of the southern transcontinental railroad, the railroad companies sold off sections of land to speculators to encourage development along the proposed route. Settlers and immigrants from Mexico to the Lower Pecos, accelerated by the completion of the railroad in 1883, included many far-sighted investors who raised sheep and cattle on vast land holdings (Carlson 1982:178). Entrepreneurs were quick to capitalize on the booming wool market, with absentee land owners and investors buying up former open range land for speculation. Landowners often leased to tenant ranchers who operated their enterprises with inexpensive migrant Mexican labor. Migrant laborers

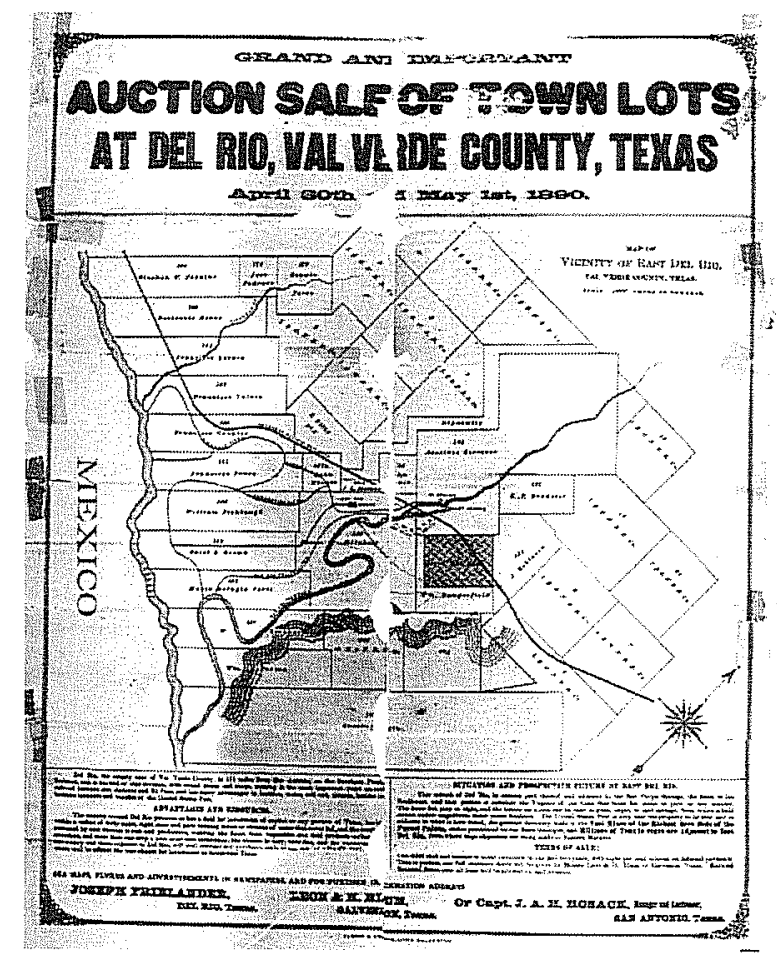

Figure 8-4. Advertisement of town lots in Del Rio, Texas, in 1890. Whitehead Memorial Museum. 
saw the opportunity to work at steady wages, and settlers arrived to provide other services to the ranchers in small growing communities such as Del Rio.

The railroad reaped economic benefits for the growing town of Del Rio. Prior to the arrival of the railroad in 1883 , wool was hauled by wagon from Del Rio to merchants in San Antonio for marketing (Mayer 1938:8). With the completion of the main line of the Southern Pacific Railway, the ambition for Del Rio to become the metropolis of the border became closer to reality as it developed its own wool markets. The population grew from 5,000 in 1881 to 12,000-13,000 inhabitants in 1922. Despite the growth in population, even as late as $1880,25-30$ million acres of unoccupied grazing lands were still found between San Antonio and El Paso (Hollon $1961: 260,262)$; unoccupied that is, by AngloAmericans. Settlement was still discouraged in some areas by the presence of Indians who were becomingly increasingly frustrated at continued usurpation of and incursions into their traditional hunting lands.

Despite the availability of land, Texas legislators encouraged patents on these frontier lands to be granted only to male settlers. Census records from 1845-1869 record no women as receiving land patents in Kinney County; in the 1870-1898 census records, only two women-Casimisa Chabarilla and Mrs. Charles Crisonta-claimed 160 acres each in Kinney County (Gould and Pando 1991:43). Beginning in 1870 , Texas legislators encouraged male settlers, discriminating against single women in the wording of constitutional and statutory laws. Discrimination against single women claiming land in Texas became even more pronounced in 1900 with the advent of state policies denying patents to single women (Gould and Pando 1991:37).

While the railroad brought settlers to this frontier area, concomitantly other innovations unintentionally created new problems. One of the most important technological innovations in the late-nineteenth century on the frontier was wire fencing invented by Joseph Glidden in 1874; spawning new episodes of settlement and fueling changing, and often divisive social relations in the Del Rio area, as well as other areas of Texas. As Montejano (1987:56-57) contends, wire fencing threatened the sheep and cattle ranchers who, owning no land, had traditionally watered and fed their livestock on open range. Fencing of ranches effectively cut them off from water sources, thus forcing many of them to move toward the Rio Grande and poorer, more arid lands to the west. By 1883 practically all rangeland in south and southwest Texas had been fenced. However, despite the fact that the true frontier closed around 1880 (Fehrenbach 1986:215; see also Limerick 1987:22-25), many areas of what are now Val Verde County remained relatively unscathed.

\section{SHEEP COUNTRY}

Sheep and goat ranching emerged as important south Texas industries in the mid- to late-nineteenth century (Cronon 1991:218; Wentworth 1938:49). By 1878 the Indian Wars had ended and, by 1900 , the Comanches had been controlled. Sheep were one of the significant imports which Coronado brought to the New World in his expedition north of the Rio Grande. The sheep business transplanted to the southwest by Spanish and Mexican pastores was adopted by Anglo-American and northern European sheep ranchers in southwest Texas in their attempts to conjoin environment with economic profit.

Beginning about 1850, sheep entering south Texas came mainly from the plains of Tamulipas, Nuevo León, and Coahuila. The number of sheep in Val Verde County increased from less than 5,000 in 1880 , to over 30,000 by the turn of the century (Carlson 1982:113-115). The arid ecosystem of the Lower Pecos had been found to be ideal for sheep ranching, the flat topography being suitable for vast grazing areas. The growing of "wooly backs" became economically intertwined with the sudden growth of urban marketplaces such as San Antonio.

The sheep business appropriated the cultural legacy of the Spanish and Mexican such as the estancias de ganado or livestock ranches (Lehmann 1969:132). The Val Verde County history (WMM/VVCHC $1976: 273$ ) suggests that by the late 1700 s, pastores based in Chihuahua were herding sheep in the area. Soon sheep were part of the breeding stock of the missions, helping to feed and clothe the colonists and the first Spanish settlers (Lehmann 1969:191). The movement of sheep into the southern Texas region was accelerated with the expansion of the sheep industry around 1870 (Lehmann 1969:70). 
Active interest in these high-risk borderlands did not actually occur until the end of the Mexican War in 1848 and the establishment of the Texas Republic. Travel was encouraged by the opening of trade routes between San Antonio and Chihuahua and the discovery of gold in California (WMM/VVCHC 1976:418). Sheep ranching, introduced by the Spanish and later adapted by the Mexicans, was realized to be a profitable industry suited to this arid landscape. This southwest area was proclaimed as the "finest country in the world for grazing, capable of sustaining a large number of sheep and goats, that the mildness of the climate would require no shelter for them during the winter months and allow grazing for the entire year" (WMM/VVCHC 1976:539). The Spanish legacy of fine-wooled merino sheep, coarser-wooled churros, goats, and sheep herding tradition of pastores and transhumanante was soon revitalized (Wentworth 1938:48) with the arrival of permanent settlers.

Among the prominent sheep ranchers listed as success stories in the Vest Pocket Guide to Del Rio, Val Verde Co., Texas in 1892 is Judge Roy Bean, who boasts a "spring and fall clip of 8000 pounds" (WMM/VVCHC 1976:263). Newspapers stress that Del Rio was becoming a city of cultured people "with a characteristic up-to-dateness," taking "the initiative in the cooperative movement through her various clubs ... so her people are fostering and developing higher ideals, greater purpose and more pronounced cumulative activity in the ethical and material advancement and uplift . . ." of Del Rio (Green 1922:27-28).

George Wilkins Kendall, a transplanted sheep raiser from New Hampshire, was accused of painting too glowing a picture of Texas resources. Kendall (1959:109) responded in scorn to what he called these "croaker" detractors, adding that "many wish to find good macadamized roads, churches of their own denominations, colleges, schools, the society of an old settled community, and good land adjoining at one dollar per acre. They should stay home or go to Kansas."

The mainstay of the sheep ranching industry was the Mexican sheep herder or pastor. In early days of ranching, when sheep were herded rather than being allowed to run free, the majority of pastores were Mexicans (Havins 1924:13) who crossed and recrossed the Rio Grande from the northern portion of Mexico according to the seasons. Hall (1986) recalls herding a flock of sheep over the border for a friend in southern Texas. He observes "that Mexicans made the best herders because the sheep minded them. For every white shepherd there are 50 Mexicans" (Hall 1986:31).

Pastores centered their life-routines around the needs of the sheep for grass, water, and protection from predators. Recent observations by an old-ime sheep rancher from San Angelo in the early 1900s, Bill Sims (Maupin 1974:33), reveals a great respect for the old-time Mexican herders' intelligence, honesty, and devotion to their sheep. He describes them as wise old men, who became extinct once wire fencing was adopted. According to Sims,

there wasn't a Mexican landowner of any size in this whole part of the country. They were mostly herders. I think they came over from Mexico a good deal like the wetbacks come over today. They were poor people who had no money. Many of them were Catholic and they reared big families and they just didn't have the money. There were no Mexican ranchmen around here [Maupin 1974:33].

Sims clearly refers here to socioeconomic differences between landed and landless Mexicans (Maupin 1974). Many of the inconsistencies and ambivalences in personal relations appear to be the differences between the Anglo-American landed gentry and the Mexicans who crossed the Rio Grande seasonally for work or moved around from ranch to ranch in Mexico and Texas (e.g. Montejano 1987).

Economic success was also a factor coloring how Anglo-Americans perceived Mexicans or MexicanAmericans involved in sheep ranching. Historic landgrant maps suggest there were enclaves of prosperous Mexican-American sheep ranch owners in Val Verde County (Lea Lincoln, personal communication 1994). However, by 1940 few individuals with Hispanic surnames are listed as property owners (Figure 8-1). No Hispanic surnames are noted in the 59 old ranch brands illustrated in the 1976 edition of La Hacienda (WMM/VVCHC 1976:20-22).

Montejano's (1987) study of Mexican and AngloAmerican relations offers the opinion that many Mexicans lost land in Texas through confiscation and 
fraud. Montejano (1987:50) also observes, "the accommodation between American mercantile groups and the Mexican upper class was, from a financial viewpoint, inherently unequal, the former had 'regenerative' wealth derived from trade while the latter had 'fixed' wealth derived from land." Moreover, long-term effects were more drastic for Mexican-American landowners with little capital, whose ranches were often purchased by AngloAmericans, thus effectively terminating not only the economic structure but an end to the landowning Mexican gentry. The land of displaced AngloAmericans, contrarily, was purchased by other Anglo-American landowners or large investment companies, thus triggering a "circulation of elites" and "elaboration of internal class differences" (Montejano 1987:73). "By 1900 the Mexican upper class would become nonexistent except in a few border enclaves . . . the old Mexican upper class in the region, which had lost with the [Mexican] war whatever influence it had in controlling the marketplace," was caught up in a losing battle with entrepreneurial spirit and capitalist nationalism (Montejano 1987:50).

Mexican nationals coming across the Rio Grande in the late 1800 s and early 1900 s were hired by the large ranches during the shearing time in the spring and early fall as sheep shearers or drivers (Lehmann 1969:55). Many of these transient workers from Mexico did not feel it necessary to learn English or to adapt to Anglo-American traditions in foods or clothing (Limerick 1987:245), a characteristic of immigrants who viewed this as a temporary opportunity to work (e.g. Hardesty 1985:222). Usually before leaving Mexico they would choose a captain, presumably one who spoke some English, from among their group (e.g. Lehmann 1969:55) to maintain order and negotiate wages with the sheep ranchers.

A paternalism toward the pastores does not obscure the prejudice and inconsistency structuring MexicanAnglo relations as they are recorded through the lenses of other cultures. A classic example of this ethnocentrism is recorded by Winifred Kupper. After admonishing Anglo-Americans for failing to understand or appreciate the Mexican sheep herding tradition, she describes the participants in a typical sheep drive as "befuddled Mexicans who, knowing nothing of geography, would start out in good faith, but becoming frightened at the distance separating them from their homes, would usually quit after the first few days" (Kupper 1921:97). Moreover, Mexican ranch hands were often taken advantage of by more unscrupulous ranchers. Fred Hall (1986:44) recalls how some of the ranchers would hire a gambler to play cards with the Mexicans to win back the money they earned from shearing and herding.

Excerpts from the letters of sheep rancher Walter W. Meek to his fiancee Eliza Duis provide a glimpse of the Mexican or Mexican-American's role in sheep ranching operations in 1887 .

Mexicans do the shearing, of course-say about twenty men do the cutting-they tie down five sheep at a time on the floor of the pen and then go to work-and as they finish their five, they tie down another lot, etc. One man will cut the wool off of about forty sheep in a day, and we pay them two cents a head and board them-there are usually about 35 to 40 men and boys gathered around the table at each meal-that includes help of all kinds.

And at night when the work is finished is the time they most enjoy and is usually spent in games, singing and gambling. They are inveterate gamblers and frequently, if not watched, their lamp will burn all night. And it is not an uncommon occurrence for men who have been working for weeks, shearing, not to have a cent when through working. They are very honest in paying their gambling debts. Shearing at last over, comes dipping, and when that is through with the flocks are sent back to their range [Lehmann 1969:59].

A sheep shearing event in the early 1900 s is described by Bill Sims.

They had whet rocks that they sharpened their shears on. The shearers could sharpen them faster than you ever saw. They tried to teach me to shear, but I never was any good at it. I cut too many sheep and left too much wool on them. Very few white men sheared in those days. The shearers took pride in their work just like the herders did. The man that could shear a lot was a big man among them. I don't know how the shearers could stand that much work, they stood on their feet and bent over. None of them ever sat down or squatted or knelt down as a rule. They just bent over when they tied the sheep's 
legs together and dropped them in the catch pen which was right down beside the open pen to the shearing floor. They would go and catch one by the hind legs and drag the sheep in. If the shearers let him crawl over on his side, well, that was kind of disgraceful. They would get him in there and with a leather string they would tie their feet together. They would start on one side of the belly and come up. It was surprising how they would roll that fleece off and how it would all stay together [Maupin 1974:42].

Sims also describes sheep shearing as a holiday event for Mexicans, although whether they were Mexican nationals or Mexican-Americans is not clear.

They would bring the family with them especially to our place because we had the Concho River running through there and they had lots of fun on it. We always sheared under some big pecan trees on the river out in the center of the ranch. They brought along tarps which they spread over their shearing pens for shade. Of course, all the work was done with hand shears. There was no machinery . . . Every one of those families had anywhere from four to eight or ten horses and burros or mules and they brought them all [Maupin 1974:39-40].

It is uncertain how many Mexican nationals crossing over the Rio Grande intended to make southwest Texas their permanent home or only expected temporary employment and wages to take back home. Other than sheep shearing or driving, the other major economic role Mexicans played in sheep ranching was that of a freighter, picking up the wool to take to the warehouse (Maupin 1974). One successful freighter or hauler of wool was Serapio Cardenas. Born in Cerralbo, Mexico, Cardenas settled in Del Rio around 1901 and by 1915, he owned a thriving business and had managed to acquire a stock of 12 mules, five wagons, and several head of horses. After delivering a load to the ranches, Cardenas would bring the wool accumulated by the ranchmen back to Del Rio. "Wool sacks then weighed from 225 to 230 pounds," he recalls, "wool weighed more than it does today because it was very greasy . . . thus attracting dirt adding to the weight" (WMM/VVCHC 1976:540).

\section{EUROPEAN INVESTORS}

In the 1880 s, prospective European buyers became the target of many land-grant agencies eager to promote settlement. Immigration movements to this area of the southwest from northern Europe included German settlers, middle-class English, and Scots, each group eager to start from the bottom up. Booklets lauding the advantages of the southwest informed immigrants that the sheep business was for poor men who could become rich overnight.

A man could apprentice himself, if need be, to another man's flocks, and from his wages soon start out on his own, for the business required little capital, a flock of sheep, a bag of beans, a plug of tobacco. Grass was to be had for the taking, and the mildness of the climate made winter feeding and winter shelter unnecessary. With the investment of three hundred dollars, the booklets read, a fortune could be made in a few years [Kupper 1921:20].

Many of these settlers likewise imported their inheritance of values, customs, and institutions to southwest Texas and adapted them to suit new lifeways on the frontier. Especially receptive to the lure of the "golden fleece" were the English, who had long maintained their own tradition of mutton-style sheep and sheep raising in the British Isles. In contrast to the fine-wooled sheep of Spain, the British sheep yielded a coarse wool (Kendall 1959:27; Kupper 1921:90). Thus, as Kupper observes, the "two great sheep cultures met-the Spanish sheep with the British sheepman; and Texas was to develop the southwest's most colorful character, the Anglo-American sheepman" who was impervious to prevailing opinions that sheep herding was an occupation for the lower echelons of society (Kupper 1921:900). Willing to work their way up from sheep herder to foreman, these enterprising immigrants often became owners of large sheep flocks (Kupper 1921:91).

Fred Hall (1986), an Irishman who became a sheep herder in southern Texas, was one of these successes. Hall describes his first encounter with sheep:

had it not been for the cussedness of the sheep it would have been a very beautiful life; out of doors, in gorgeous weather and in beautiful 
country. But the sheep were a dreadful nuisance, and had to be most carefully watched, going off in little bunches up the mountain hollows and they kept me running around the herd all day until the heat forced them to seek shelter beneath the trees [Hall 1986:27].

Although many of the English failed at sheep ranching, it was said that in Texas it was unlucky to hire a Scottish sheep herder because "he'll end up owning your whole flock" (Kupper 1945:69). Kupper attributes the Scot's success to their literacy, maturity, sagacity, and rugged individualism, epitomized by sheepmen such as Robert Maudslay (Kupper 1951), whose letters chronicle his remarkable life.

Sheep raising, despite a high initial monetary investment and hard work, gave high returns to the outside speculator and, in many cases, profits were doubled annually (Carlson 1982:53). As Randall (1860) observed,"the sheep is a prompter paymaster [than the cow]. He pays you annually. And he never dies in your debt." Sheep raising also yielded greater returns than cattle because wool was easy to store and transport. Another important factor, considering the aridity and lack of permanent water sources in this area of southwest Texas, was that sheep, in contrast to cattle, did not require much water (Lehmann 1969:37-40). By about 1870 (Wentworth 1938:49) a second episode of investors and settlers was lured to the Del Rio area by the profitability of sheep ranching.

\section{AMERICAN INVESTORS}

By 1910 the distribution of sheep ranching had shifted from the newly deteriorated and overexploited Rio Grande Plain to southwest Texas, bringing with it a boom in land speculation and real estate. A new wave of immigrants with money in their pockets (Edwards 1922:44; see also Lehmann 1969:121-123) comprised this second wave of migration. Sheep ranchers quickly became the center of interest, with retail merchants in Del Rio such as Mr. James McLymont (also a sheep rancher) directed towards satisfying the "needs, the wishes, the preferences of the ranchman, and satisfying them to the minutest detail" (Adams 1922:22). In 1915 the Texas Sheep and Goat Raisers' Association was formed to insure the betterment of the growing industry (La Cross
1922:44-45). The first meeting, held in Del Rio at the Princess Theatre, was attended by many prominent Texans (Figure 8-5).

The invention of the automobile initiated an episode of rapid change by providing a convenient mode of transportation for settlers and supplies. A 1922 edition of Sheep and Goat Raisers' Magazine describes Del Rio as a "cosmopolitan town of citizens from the East, the South, the North, and the Great West" (York 1922:25). Two highways, the Great Canadian Highway running north-south and the Robert E. Lee Highway running east-west, assured easier access to the Del Rio area (Laufenburg 1922: 49). The first automobile dealership appeared in 1909 with the introduction of a two-cylinder Maxwell (Morris 1922:40). Additional benefits were accrued to many local sheep ranchers who had traveled hundreds of miles to Del Rio by horseback or wagon and team to purchase fresh provisions or transact business. These infrequent visitors could now drive into town every week or two in their automobile or if very prosperous, would maintain a home in town from which to direct business (Morris 1922:40).

Wives of sheep ranchers now had the opportunity to participate in Del Rio's cultural and social events such as literary and social clubs or the ParentTeachers Association, while their husbands could be more active in the Chamber of Commerce or Booster Club (Forman 1922:26). Additional social activities included golf for men at the San Felipe Country Club, boasted as one of the "sportiest golf courses in the country" (Stafford 1922:30-31). Luncheons of the "New Century Club" and the "Shakespeare Club" were among the popular social activities popular for women (Gillis 1922:25-26). Quality education also became available to ranch families in the Del Rio area through improved transportation modes.

By 1921 this area of the southwest was recognized as one of the best inland markets for lambs and mutton as well as its fine-blooded cattle (Martin 1922:18-19; Stafford 1922:19). The ranges of Mexico, now almost devoid of livestock due to social and political unrest, were restocked from the ample livestock pantry of Del Rio, its ranchers intent on producing sheep that would produce "the maximum of fine wool, and at the same time, command the respect of the packers for mutton purposes" (Martin 1922:19). Buyers from the grain-producing area of the northern 
United States also came to Del Rio to invest in lambs and mutton (Martin 1922:18).

Central to this prosperity was the Rambouillet, a breed of sheep developed from a small herd of Spanish sheep on a farm near Paris, France, and first imported into the United States by George Kendall of Boerne, Texas (Wentworth 1938:49). Del Rio, known for its high grade and "heavy clips" of Rambouillet wool, lambs, and mohair soon became one of the largest warehouse and shipping centers of the southwest, transporting lamb, mutton, and cabrito directly to eastern markets and feed pens in cities such as Chicago (Wentworth 1938:49). Proximity to the Southern Pacific Railroad also connected this frontier outpost to these lucrative economic markets.

\section{OTHER FRONTIER PARTICIPANTS}

Strands of the frontier narrative of southwest Texas bequeathed to us are often uneven, for women were usually pictured as marginal to historic events and economic concerns. Winifred Kupper, a noted historian and folklorist, wrote numerous articles and a widely circulated book on sheep ranching, The Golden Hoof, in 1945. Her chronicles of sheep herding and early women in Texas, although often ethnocentric and highly romanticized, provide us with a glimpse of early women involved in sheep ranching. Kupper (1945:174) describes a society woman living in a "handsome stone house" who had to turn "a sheep camp into a home with furniture made out of boxes, rugs of tanned sheep's hides to cover dirt floors, magazine pictures pasted on canvas walls, mattresses of cattail fluff stuffed into cases made of flour sacks."

In some cases women were not just homemakers, but business partners who learned to accept that the sheep came first and that their necessities had priority over those of the family. "A trip to town for flour and sugar had to be delayed if the sheep needed doctoring for worms. The broken-down old kitchen stove had to suffice if the sheep needed a new dipping vat. There was no going to a barbecue, a party, or even church if the sheep needed attention" (Kupper 1945:176). Women, moreover, took over sheep-herding activities in the absence of their husbands, and participated in sheep shows, auctions, and sheep-raiser organizations. One of the first presidents of the Sheep and Goat Raisers' Association was Mrs. Willie B. Whitehead of Del Rio (WMM/VVCHC 1976:533).

The frontier epic also frequently overlooks the roles of ethnic groups such as Mexicans, MexicanAmericans, and Native Americans as equal participants in the events occurring in this vast space of southwest Texas (Schuyler 1991:13). Despite the integration of these ethnic groups into the American frontier, many carried cultural traditions considerably different from, and often in opposition to, the controlling socioeconomic or cultural group. The frontier is often pictured as the exclusive domain of the cattleman who is romanticized as a hero, destined to struggle against the environment, bandits, wild Indians, and predators. As one male chronicler of the west notes, the "pioneer cattlemen constituted the vanguard of a civilized people who have played the most conspicuous part in shaping the destiny of western civilization" (Jones 1927:95). Another chronicler observes, "a big country required big men, heroic men, mobile men, men on horseback to conquer and subdue it-to bring it to pasture" (Goetzmann 1986:73). In an ironic twist, this vision of Texas included the appropriation of other ethnic groups or cultures, in this case the cowboy adopted the north Mexican cattle culture, including costume, life-style, and jargon, along with the longhorns left behind by Mexican ranchers (Fehrenbach 1986:214).

Certainly the "white sheepman" was part of this mythic social network (Kupper 1921:89), often juxtaposed in the literature to his antagonistic counterpart, the cattleman. Popular stories of western expansion emphasized the fundamental differences between cattle and sheep, but the fact was that a fortune could be made in sheep ranching, not cattle ranching. As longtime pragmatic sheep rancher Bill Sims observed, "in choosing whether to raise sheep or cattle, you might say that it depends on whether you want to put on a big hat and boots and say that you're a cowboy or whether you want to make money" (Maupin 1974:21).

Even old-time sheep raisers recognized their lower status in the early days. Bill Sims, for instance, who raised both sheep and goats, notes that "everybody who has ten cows says that he is a cattleman; and yet if he has a thousand sheep, he just doesn't say much about being a sheepman ..." (Maupin 1974:21). The low prestige of sheep ranching was especially 
prominent in the west where sheep herding was degrading and unromantic.

In southwest Texas, the sheep-herding business was associated with Mexicans even after it was adopted by Anglo-American entrepreneurs (Kupper 1921:89). Moreover, the association with Mexicans lent an ethnic taint to sheep raising in some areas of the Southwest according to one historian, because it was considered as "a business for Mexicans and not for "white men'" (Kupper 1921:89). As one sheep rancher observed, "sheepmen were associated with Mexicans-therefore, cattlemen equated all sheepmen with 'inferior' people conquered at San Jacinto" (Maupin 1974:16). Montejano (1987:82) likewise contends that these racial sentiments which "drew heavily from the legacy of the Alamo and the Mexican War, were maintained by market competition and property disputes." Despite the fact that some sheep herders were Anglo-American or even Euro-American, the designation "sheep herder" became an invective for an inferior breed of "white man" (Kupper 1921:90) and early sheep herders suffered many indignities (Havins 1924:12). "In the early cowboy's estimation there were two classes of human beings, white men and sheepmen, and many a man who toyed with the idea of 'fooling with sheep' was loathe to face the stigma" (Kupper 1921:89).

Material culture perpetuated many of these cultural distinctions based on ethnic origins. For instance, the adobe house was not only economically feasible to many ranch owners in southwest Texas, but a practical means of adapting to the harsh, arid environment and the difficulty of obtaining wood for building materials. According to Graham (1978:44 citing Wulfkuhle 1986:38), however, adobe houses had a social stigma among Anglo-Americans; therefore, gabled roofs were adopted to raise the social status of an adobe house, a modification that was made to the adobe ranch house on the Zacatosa Ranch.

\section{SUMMARY}

The frontier process was a dynamic interaction between the environment, historical processes, and ethnic and social relations. A system of forts expanded with each new wave of settlers, threatened by Indian groups whose own lands and resources were steadily diminishing. A series of irrigation canals in Del Rio created an "oasis" of farmland luring potential settlers from Europe, Mexico, and the northern United States. During the 1880 s, the major conduit to this frontier area became the railroad system, creating additional incentives for the Del Rio area to become a major center for sheep and goat raising. By the turn of the twentieth century, this area of southwest Texas could claim its place as one of the nation's largest producers and warehousers of wool and mohair (Texas Almanac 1933: 165). The latter had become a popular textile for draperies, linings, rugs, and upholstery. Before 1900, Texas supplied 71 percent of the nation's Angora goats and mohair. By 1930 that number had increased to over 84 percent (Carlson 1982:200). Del Rio was an integral part of the regional and state economy until the invention of synthetic fibers in the 1950s and 1960s (Carlson 1982:213).

\section{THE LAUGHLIN AFB PROPERTY}

The property that was to become Laughlin Air Force Base was originally comprised of three tracts of land: H. C. Tardy Survey No. 1961/4; the El Paso Irrigation Company Survey No. 1961/2; and portions of the Illinois and Galveston, New Orleans Rail Road Company Survey Block No. 3 and the J. Jones Survey No. 871 (Figure 8-6). These lands were consolidated under a single owner, W. K. Jones, in 1885. Jones sold the property in 1887 to S. J. Woodhull, beginning a chain of absentee ownerships that continued until the time the property was purchased from B. S. Harrison by the Department of Defense (DOD) in 1942 (Knapf et al. 1994). 


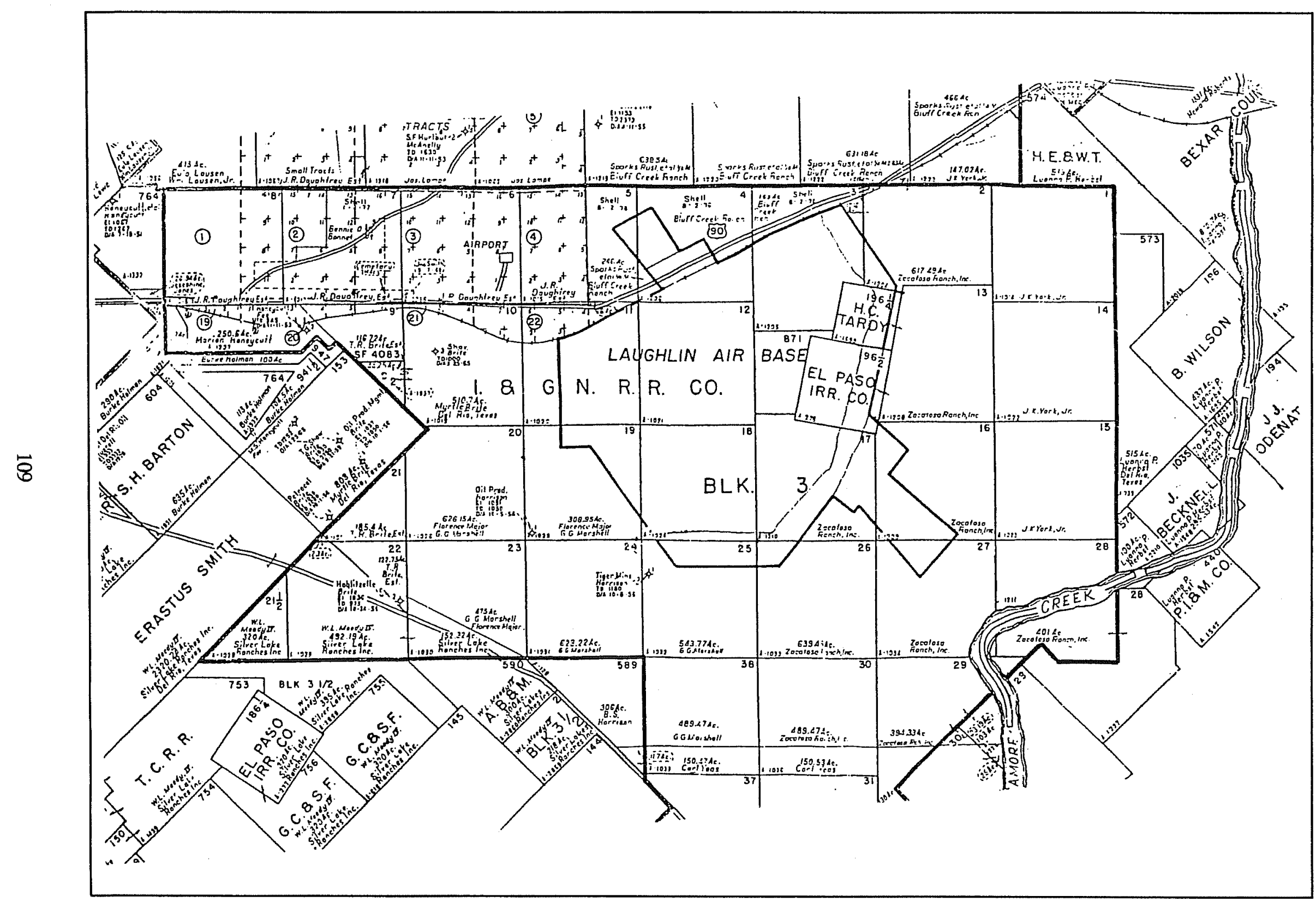

Figure 8-6. Map of Laughlin Air Base showing original long-lot grants and ranches. 


\section{THE ZACATOSA RANCH}

The Marshall family of Belvedere, Illinois, began leasing the property from R. A. Harrison in 1921 or 1922. Many of the recollections, Marshall family photos, and descriptions of the ranch operations in this study are from correspondence and telephone interviews with members of the Marshall family, Florence Marshall Major and Anselyn Marshall. Florence, Gilbert C. Marshall's daughter (Figure 8-7), grew up on the ranch and was a young girl of 13 when the Harrison (Zacatosa) Ranch was purchased by the DOD in 1942. Anselyn is married to Gilbert C. Marshall's son, Gilbert G.

George M. Marshall, a prominent livestock feeder and landowner from the Midwest, met Ben Harrison on a train while passing through the area. George Marshall was persuaded to lease the Harrison Ranch sight unseen, and sent his son Gilbert C. Marshall to run the ranch. Gilbert was suitably armed for this task, having a degree in agriculture from The University of Wisconsin. The ranch was a family enterprise, with many members of the Marshall family visiting to assess the operation, which they turned into a profitable sheep ranch (Figures 8-88-10).

Upon arriving at the ranch, Gilbert $C$. found not only that it lacked livestock and buildings, but that the only employee on the ranch, an elderly Mexican, spoke no English. A well had to be drilled to bring potable water to the ranch. Gilbert $C$. had to hire laborers to build the adobe home in addition to all the ranch structures and cross fences. Florence Marshall Major does recall an old house located near Sacatosa Creek (see Chapter 10). This structure was already abandoned when the Marshalls began leasing the property. Florence also reports that her father quipped from time to time that "chickens were better housed in Illinois than people in Texas."

The ranch, leased by the Marshall family for $\$ .50$ an acre per year, consisted of 15,000 acres and was primarily concerned with the production of Rambouillet lambs and wool (Laughlin AFB, Base Properties Files [BPF]) (Figure 8-11). Gilbert C. Marshall raised sheep and shipped them to stockyards or other western markets. Although primarily a sheep rancher, Gilbert C. Marshall also had a tripartite operation, in local terms a "combination" ranch, raising other livestock such as goats and cattle in addition to food crops. According to appraisal records, the southeastern part of the ranch near the creek was once cultivated in corn, oats, and barley. Also included in the appraisal listed in the loan application provided by Marshall to the DOD in 1942 were 50 angora nannies with kids, 140 Rambouillet bucks, 40 mutton goats, 30 Spanish goats, 25 wethers, and 40 horses (BPF) (Figures 8-12 and 8-13).

Gilbert C. Marshall married Macye Earwood after he arrived in Texas. Macye was the youngest daughter of G. C. Earwood, from an old, prominent ranching family in Texas (Figures 8-14 and 815). Macye was a very well-educated woman, which was unusal for her generation, having attended Mary Hardin Baylor College for three years. Florence recalls that her mother was a leader in Del Rio literary events and an excellent horsewoman. Florence also recalls that Macye worked very hard and was of enormous support to her husband on their ranch.

One of her duties, like hundreds of other sheep ranch wives, was to feed orphaned livestock on bottles and to make a mash for baby chickens. She also pasteurized the milk, pouring it
Figure 8-7. Florence Marshall Major with her younger brother, Gilbert G. Marshall, ca. 1942. 
into pans to be put in the ice box. The ice had to be purchased in town at the ice house. Later Macye had a butane refrigerator and stove. Florence relates that later the refrigerator did catch on fire and burned part of the kitchen. This event may have led to the eventual separation of the kitchen and dining room from the main house.
Florence recalls that many Mexicans were hired to work on the ranch. Among them was Tomás, who brought his wife, Josepha, and children with him from Mexico (Figure 8-16). Florence recalls an incident as a small child in which she was threatened by a rattlesnake. Josepha, cleaning the house, came outside and picked up the rattlesnake and threw it over the fence.

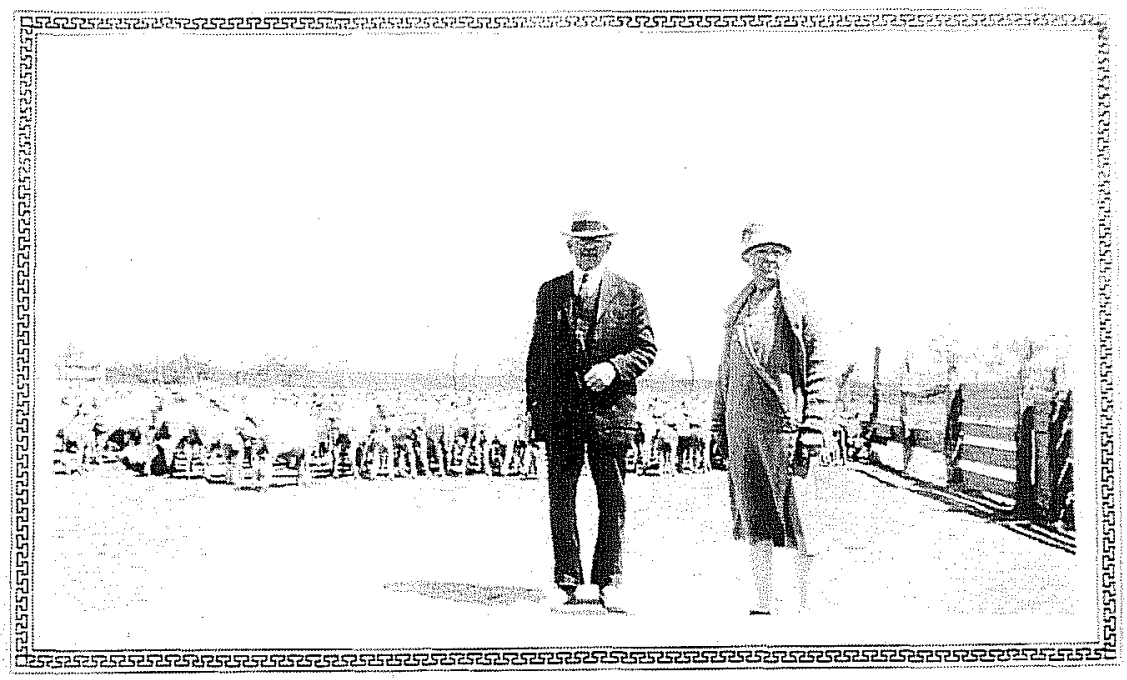

Figure 8-8. George $M$. Marshall and his wife Susie, in front of the ranch corral.

Figure 8-9. George $M$. Marshall and his brother Taylor, standing on the porch of the little adobe house.

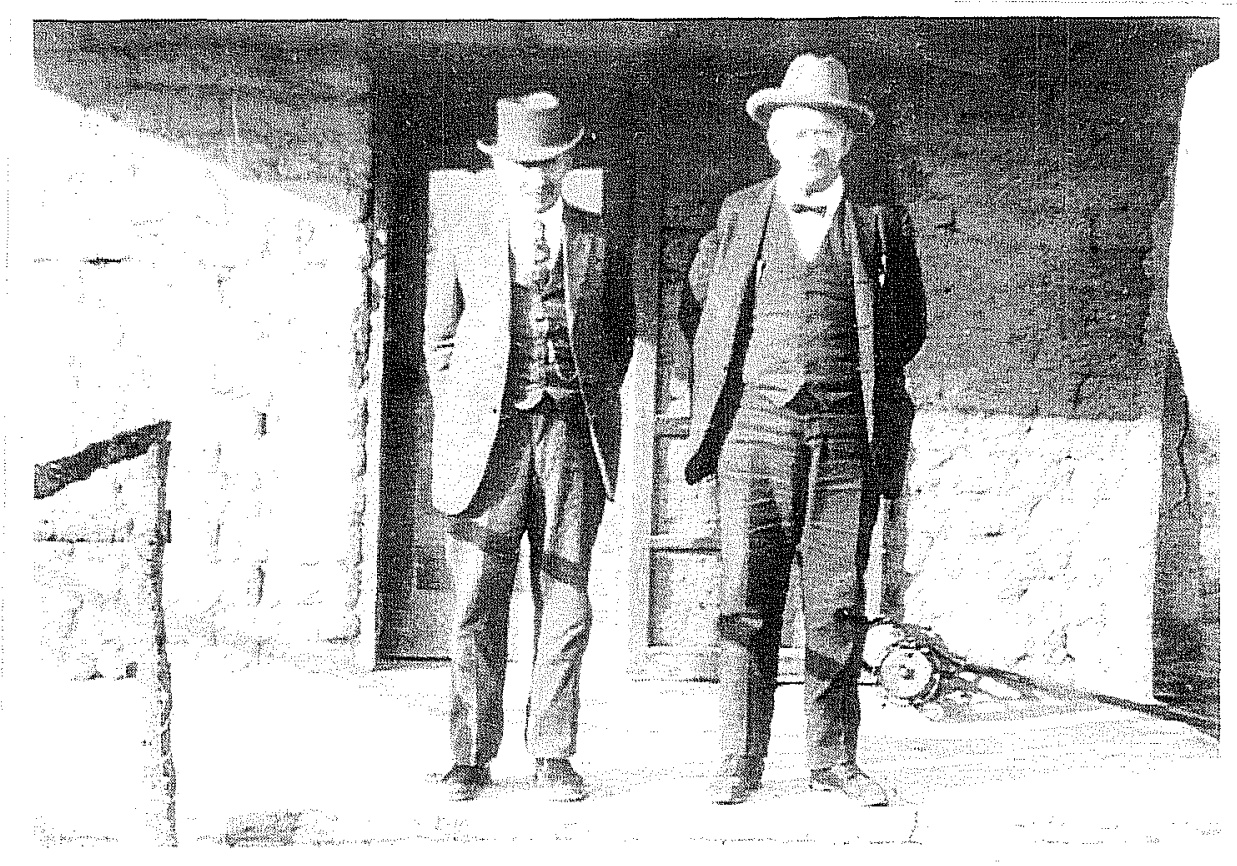


Figure 8-10. George M., Susie, and Taylor Marshall, and the cook at the chuck wagon.
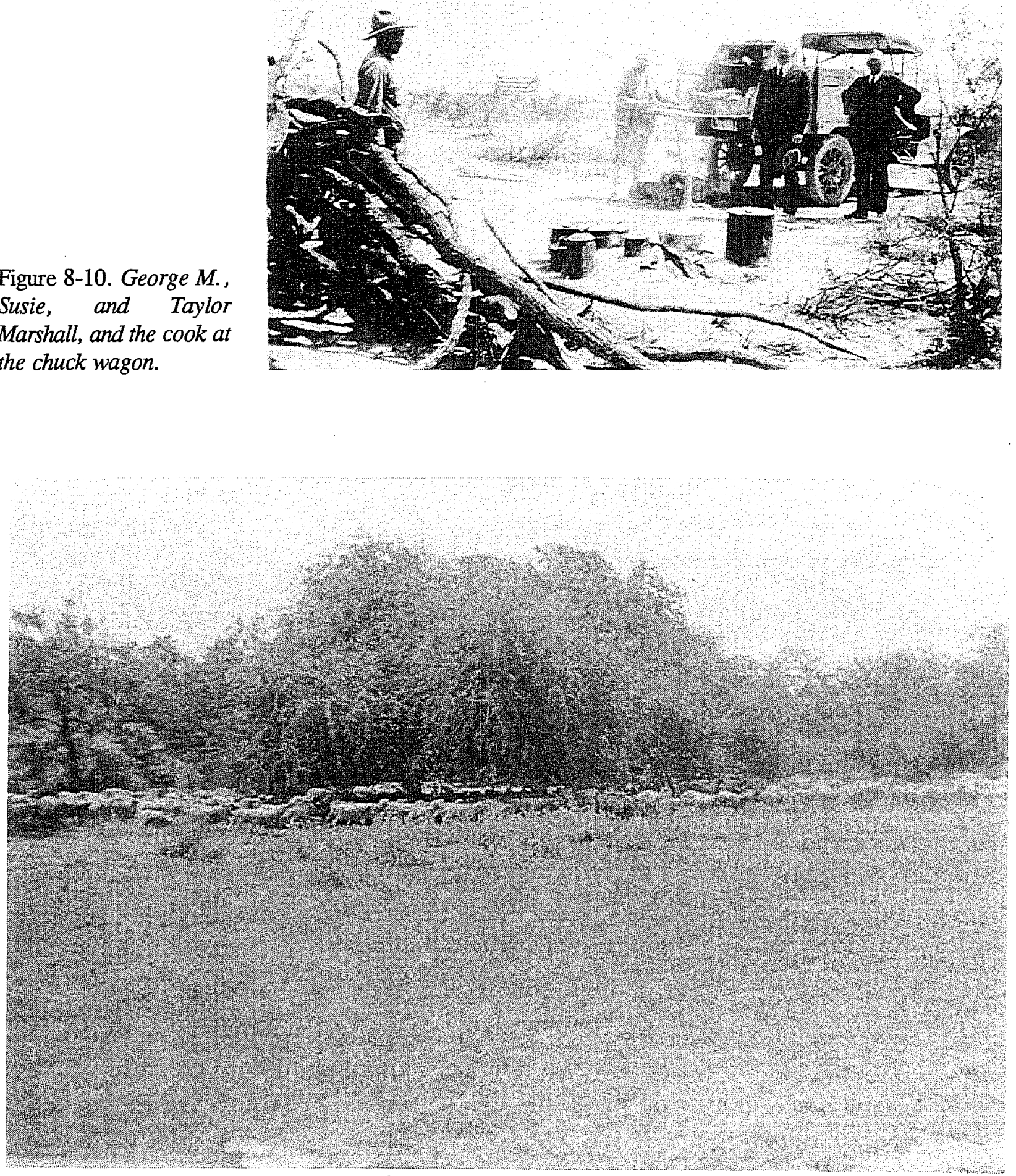

Figure 8-11. Rambouillet sheep herd to the west of the ranch headquarters. 
Figure 8-12. Gilbert G. Marshall shown with his horse, near the stock tank.

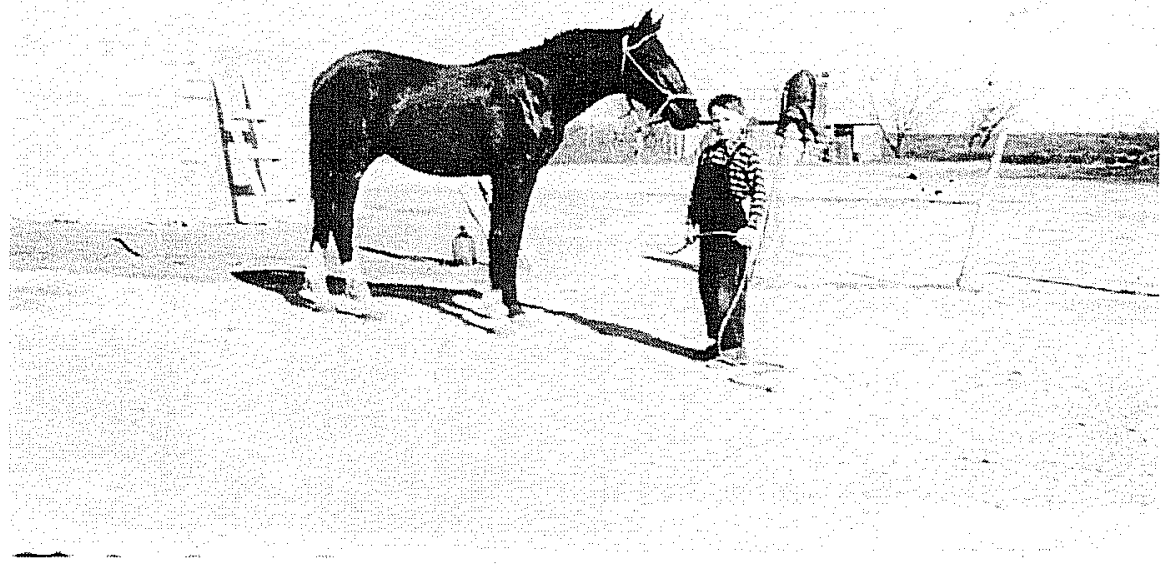

Figure 8-13. Gilbert G. Marshall showing off his blue-ribbon sheep at a 4-H event.

Many of the ranch hands would cross over from Mexico; there was not the idea of a boundary as there is now (Anselyn [Mrs. Gilbert G.] Marshall, personal communication 1994). At one interval Gilbert C. hired black workers, but this did not last long since blacks and Hispanics had a difficult time working together, according to Florence Marshall Major. One AngloAmerican foreman was hired during the Depression and he lived in the little adobe house at the headquarters.

Florence also recalls that wild animals were a constant problem on her father's ranch. Predators included panthers, coyote, wild cats, and in earlier times, bear. Her father would hire government trappers to keep the predator populations down. Healso kept hounds with which to hunt down predators. On the ranch, over 70-80 miles of 48-inch woven wire with barbed strands at the top and bottom were intended to thwart both human and animal predators (BPF).

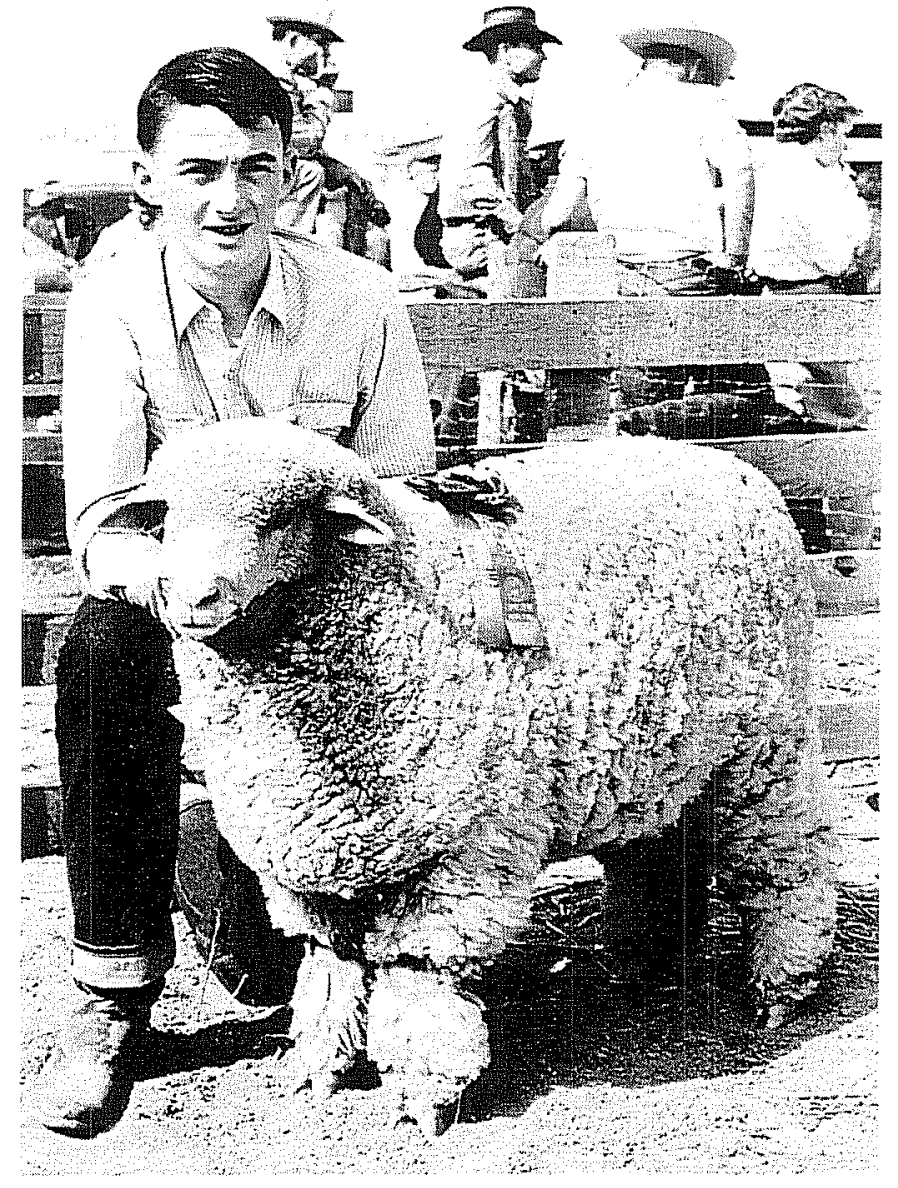


Figure 8-14. Macye Marshall with her infant daughter Florence, in front of the main house.
Figure 8-15. Gilbert C. Marshall with his wife Macye (right), a Marshall cousin (left), and the cousin's daughter.

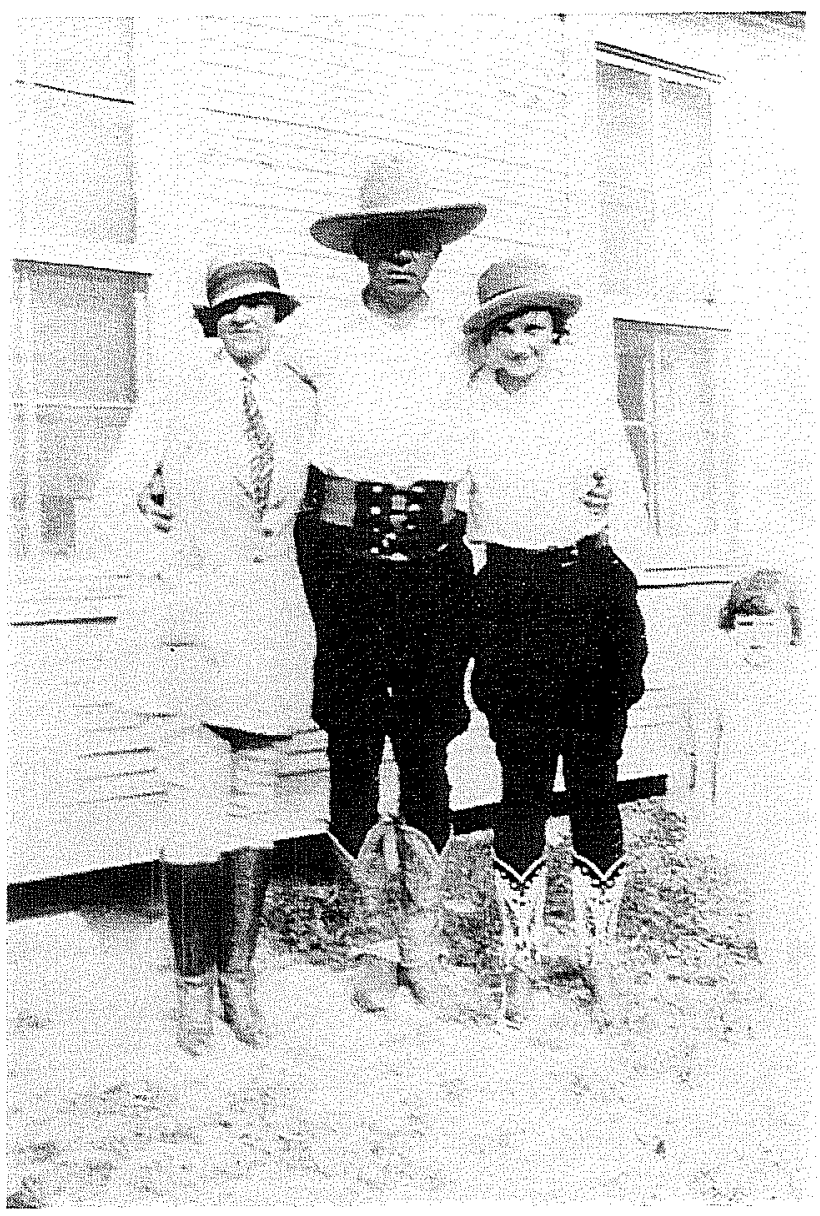

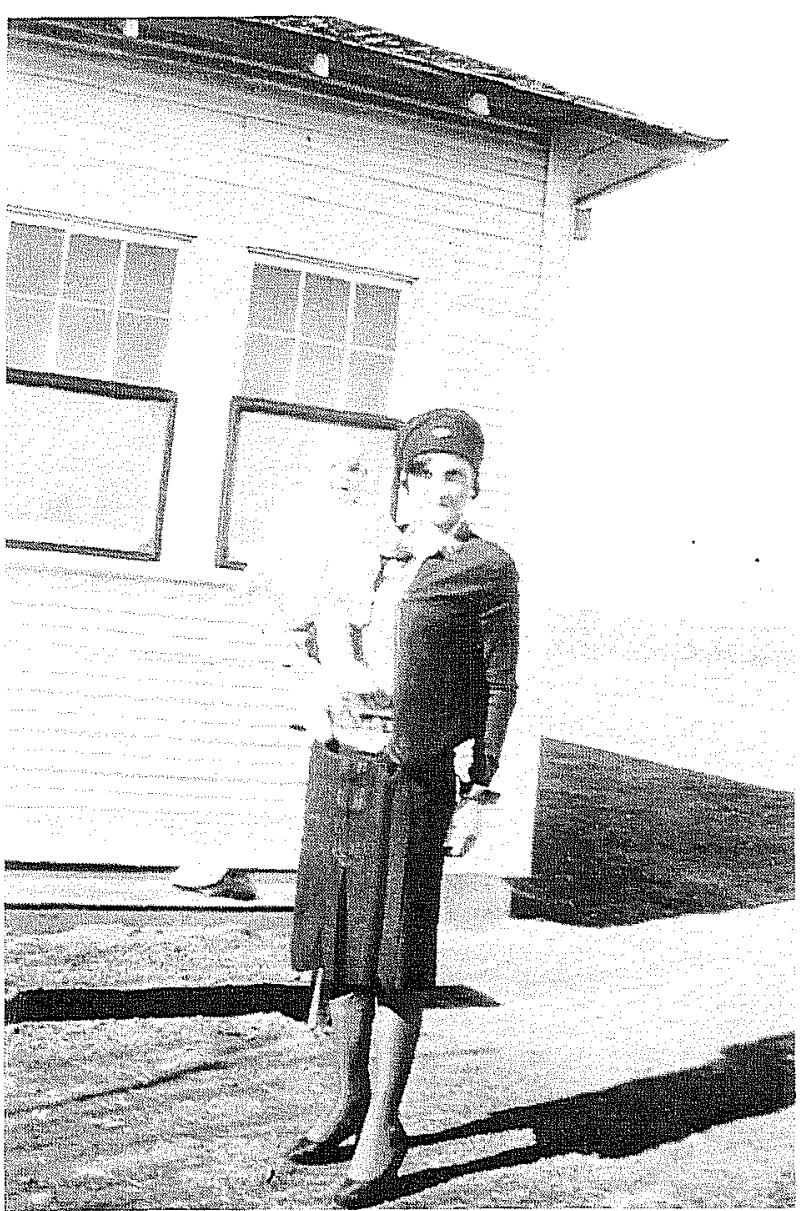

With the Marshall family business connections and his business acumen, Gilbert C. was able to run a very profitable sheep ranch and purchase new properties. He purchased land on the Pecos River in Val Verde County and land between Carrizo Springs and Crystal City on which he fattened ranch stock. This portion of the ranch is owned by his son Gilbert $G$. Marshall, of San Antonio, today.

A 1942 map of land plots shows six land plots south-west of Laughlin Air Base owned by the Marshall family (BPF) (Figure 8-2). Additional land plots southeast of Laughlin extending to and across Sycamore Creek are listed as the Zacatosa Ranch, Inc., parts of which were also leased by the Marshall family. 


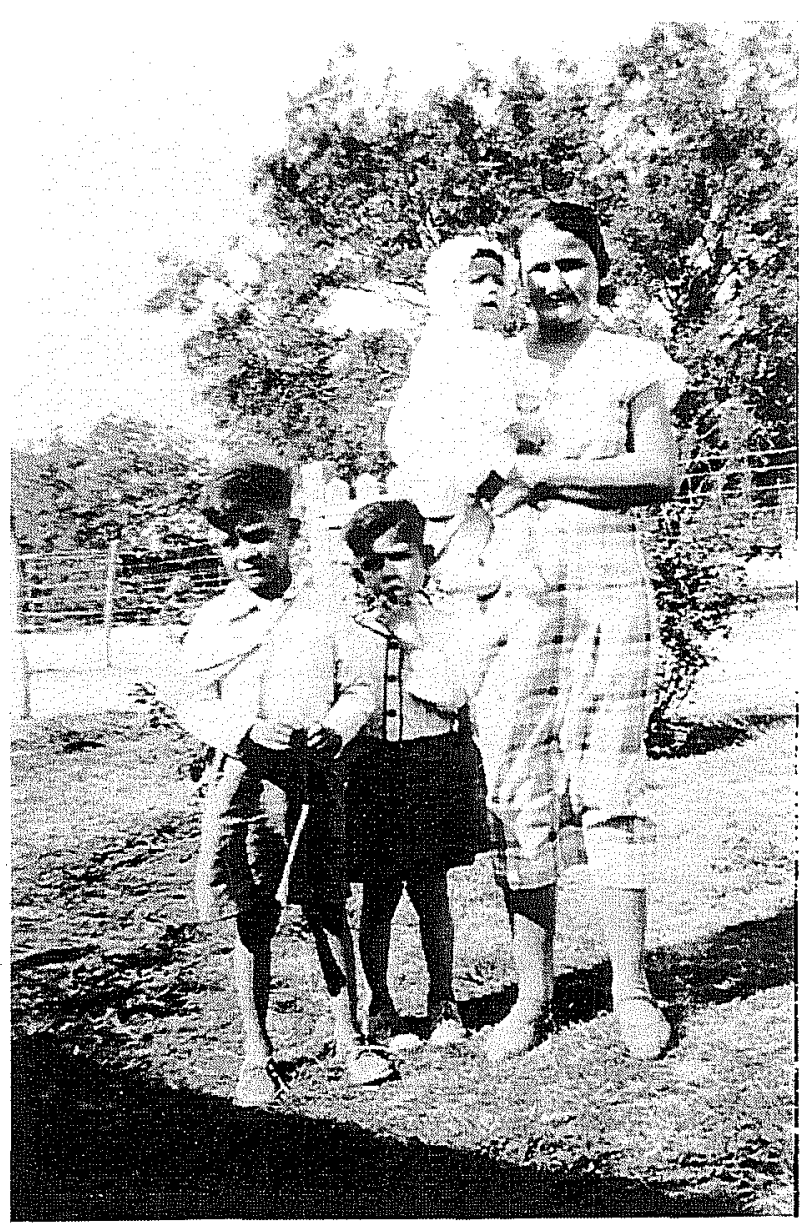

Figure 8-16. Josepha, wife of Tomas, the MexicanIndian foreman, with her children.

\section{LAUGHLIN AIR FORCE BASE}

In 1942 a 3,862-acre portion of the Zacatosa Ranch was purchased by the U.S. military for a new air training base. At this time Mr. Harrison observed that the land taken was the "choicest portion of the 15,000 acre ranch" embracing "a large mesquite flat which was cut in pastures on which grazing had been restricted and was used for lambing and the growing of lambs. This area also embraced all the ranch headquarters, pens, traps, shelters, and the principal waterings were the only permanent sweet water on the ranch" (BPF). Moreover, its location on "Jonestones [sic] Switch and Pens of the main line of the Southern Pacific" and its location near permanent sources of water added considerable value to the ranch (BPF). Additional desirable features included a lake, four wells, and three water tanks. B. S. Harrison asked for and was given permission to remove nine of the buildings that made up the headquarters of the Zacatosa Ranch where the Marshall family had lived for 20 years (letter from CO, Laughlin AFB, to DE, S.A.D. 31 October 1944, [BPF]).

The Air Force had first become interested in the Del Rio area early in the twentieth century when planes flying from San Antonio to El Paso during the Mexican Revolution would layover in Del Rio. This arrangement became permanent during WWII with the Zacatosa purchase (Knapf et al. 1994). The new air base on the site of the Zacatosa Ranch was originally activated as the Del Rio Bombardier Training Facility and, on November 11, 1943, was redesignated Laughlin Field, in honor of $\mathrm{Lt}$. Jack $\mathrm{T}$. Laughlin, the first local citizen killed during World War II. The base's stated mission was to conduct flight training for the Air Training Command. In October 1945, the base was transferred to the Air Material Command, placed on inactive status, and closed.

With the advent of the Korean War in 1951, the base was returned to the Air Training Command and designated Laughlin AFB. Laughlin conducted flying training until 1957, when it was transferred to the Strategic Air Command, with its primary mission to serve as the home station for U-2 reconnaissance planes that performed high altitude photographic coverage of "Iron Curtain" countries. In 1962 the facility was returned to the Air Training Command for the purpose of flight training. Laughlin AFB was again considered for closure in June 1995 by the Base Realignment and Closure Commission, but the commission voted to maintain the Air Education and Training Center. 


\section{Chapter 9. Historic Site Descriptions}

\section{Anne A. Fox, Anna Jean Taylor, and Barbara A. Meissner}

Two Historic period sites were recorded during this project. Site 41VV1654 has a prehistoric and two historic components. Site 41VV1682, the original location of the Zacatosa Ranch headquarters, is a single-component site.
The two apparent livestock troughs, Features D and $E$, were situated in the extreme western part of the site (Figure 5-2). These two features are essentially identical in construction (Figure 9-1). Both are rectangular cement features measuring $4.65 \times 0.60 \mathrm{~m}$ $(15 \times 1.9 \mathrm{ft})$ in the interior, with vertical sides

\section{VV1654}

A detailed description of the setting and prehistoric component of site 41VV1654 is presented in Chapter 5. Historic features within site 41VV1654 consist of an artifact scatter, designated Feature $\mathrm{C}$, and two apparent livestock troughs, designated Features D and E. Feature $\mathrm{C}$ measures approximately $20 \times 40 \mathrm{~m}(6.5 \times 13 \mathrm{ft})$ and is located in a mechanically bladed area in the southern part of the site (Figure 5-2). Feature $\mathrm{C}$ is a large, thin scatter of historic artifacts including ceramics, bottle glass, and metal fragments. The scatter appears mainly limited to the bladed surface, which is approximately 3 to $5 \mathrm{~cm}$ (1 to 2 inches) below original ground surface. The subsurface recovery of window glass and one undecorated semiporcelain sherd in a shovel test dug within the feature suggests additional historic artifacts may be buried. However, these artifacts were recovered from a severely disturbed context. Artifacts from Feature C suggest a pre-1900 date, as only cut nails were observed. A limited amount of prehistoric material, consisting of a chert projectile point and chert flakes, was also present within this Historic artifact scatter.

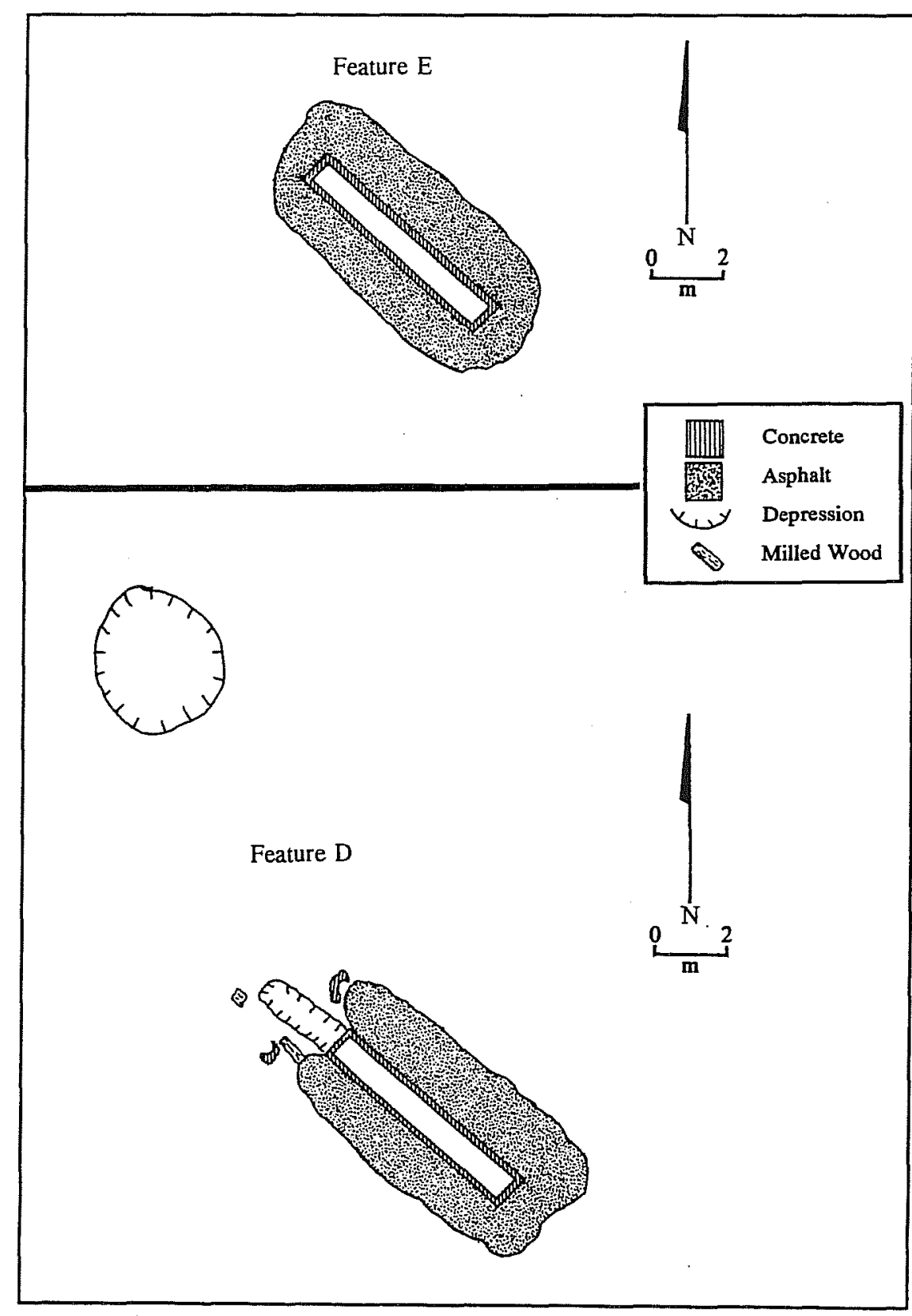

Figure 9-1. Features D and E, site 41VV1654. 
measuring 8.5 to $9.0 \mathrm{~cm}$ ( 3 inches) in width, and $32 \mathrm{~cm}$ (1 ft) in depth. The ground surface surrounding both concrete features is covered by asphalt paving measuring approximately 1.5 to $2.0 \mathrm{~m}$ (5 to $6 \mathrm{ft}$ ) wide. Features D and $E$ are situated

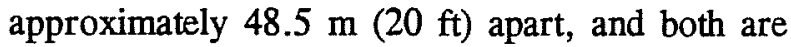
oriented at a bearing of $130 / 310^{\circ}$.

Between Features D and E, at a distance of $22 \mathrm{~m}$ $(72 \mathrm{ft}$ ) from the northern end of Feature D (the southern trough), is a circular depression measuring approximately $2 \mathrm{~m}(6.5 \mathrm{ft})$ in diameter and 5 to 10 $\mathrm{cm}$ (2 to 4 inches) in depth (Figure 9-1). The origin of this depression is unknown. Near the northern end of Feature D are two cement fragments, apparently representing the remnants of a collar for a 12-inch pipe, and a few stray pieces of asphalt and cut wooden board fragments. Unlike Feature E, the asphalt surrounding Feature $D$ did not cover the northern end of the trough. Instead, extending approximately $2 \mathrm{~m}$ ( $6.5 \mathrm{ft}$ ) from the end of the
Feature D trough was a shallow rectangular depression of approximately the same diameter as the trough, but of unknown origin (Figure 9-1). The only cultural material observed in the vicinity of Features $D$ and $E$ were asphalt and cement fragments, a few bits of tin can fragments, and miscellaneous metal.

Approximately $1.5 \mathrm{~km}$ (1 mile) to the northwest of the troughs is the Zacatosa Ranch, site 41VV1682 (discussed below), which contains a third historic livestock trough. The dimensions of this trough (designated Feature A for site 41VV1682) are the same as those for Features $D$ and $E$ at site 41VV1654.

Dogleash Inventories

Six dogleash artifact inventories were performed within site 41VV1654 (Figure 5-2). Dogleash Unit \#1 was located in the central part of Feature $C$, the historic scatter, in the southeastern part of the site. An inventory of historic artifacts from this dogleash area is provided in Table 9-1.

Table 9-1. Dogleash-Unit Inventory for Site 41VV1654, Feature C.

\begin{tabular}{|c|c|}
\hline Historic Artifacts & Quantity \\
\hline Cut limestone fragments & 2 \\
\hline Bricks and fragments & 2 \\
\hline Cut nails & 11 \\
\hline Window glass & 30 \\
\hline Slate & 1 \\
\hline Misc. metal fragments & 2 \\
\hline Bottle glass & 121 \\
\hline Undecorated whiteware & 20 \\
\hline Transfer print & 2 \\
\hline Undecorated semi-porcelain & 28 \\
\hline Stoneware & 1 \\
\hline Mother-of-pearl fragments & 1 \\
\hline Total & 221 \\
\hline
\end{tabular}




\section{VV1682 ZACATOSA RANCH HEADQUARTERS}

Site 41VV1682 (Figure 9-2), the Zacatosa Ranch Headquarters, is located in a large, mowed field northeast of the base airfield. The site area is currently part of the safety zone for the airfield and has been bladed by heavy machinery in the past.

\section{SITE SETTING}

The site area has been extensively disturbed by machine blading, further smoothing the already level topography. Located on an upland terrace of Sacatosa Creek, approximately one kilometer to the east, the site lies about $328 \mathrm{~m}(1,075 \mathrm{ft})$ above sea level.

\section{Soils}

The site soils are from the Acuna series, which consists of deep, nearly level soils found on stream terraces and low uplands (Golden et al. 1982). The only erosion likely at the site is from sheetwash occurring during heavy rains when the ground surface cannot absorb the water adequately.

\section{Vegetation}

Site 41 VV1682 is located within the upland flats biotic zone, as defined by Flyr (1966), but has been extensively modified by mowing. Grass species were not identified, as they were all cut very short (1 to 1.5 inches). Mower-stunted shrubs such as falsemesquite prairie acacia (Acacia texensis), and even some cenizo were also present (Everitt and Drawe 1993; Hatch and Pluhar 1992). The remains of sawed tree stumps dot the site as well. In many areas of the site vegetation is very sparse or nonexistent. Ground surface visibility ranges from approximately 25 to 100 percent, depending on the grass cover.

\section{SITE DESCRIPTION}

The site consists of historic features and artifacts spread over a 140-x-210-m (450-x-690-ft) area. Fourteen historic features are present at or immediately below the modern ground surface. The features represent the remains of early twentiethcentury ranch buildings with associated cultural material. Archival research indicates this was the
Zacatosa Ranch Headquarters occupied between the early 1920s and 1942. The ranch headquarters included 12 structures as listed on the land valuation form that is part of the records kept of the transaction.

\section{Features}

Feature A (Figure 9-3) is a rectangular concrete structure measuring $4.85 \times 0.78 \mathrm{~m}(15.9 \times 2.5 \mathrm{ft})$, with walls 9 to $10 \mathrm{~cm}$ ( 3.5 to 4 inches) thick. The long axis lies roughly northeast-southwest, at a bearing of $65^{\circ} / 245^{\circ}$. Lag bolts are set into the eastern end of the structure. The structure lies flush with the modern ground surface and is surrounded by a broken paving of asphalt. A moderate to dense scatter of historic artifacts consisting mainly of construction debris such as nails, plaster, and window glass, is present around Feature A. Bottle glass and a miscellaneous assortment of other historic artifacts are also present. Feature $\mathrm{A}$ appears to be the base of a livestock watering trough. It is identical in size, shape, and presence of asphalt paving to two trough features (Features D and E) from site 41VV1654. The latter two features are probably also associated with the Zacatosa Ranch.

Feature B (Figure 9-3) designates a line of seven flat, undressed sandstone slabs oriented at a bearing of approximately $15^{\circ} / 195^{\circ}$. Feature B slabs are located in the southeastern part of the site, and are approximately $10 \mathrm{~m}(33 \mathrm{ft}$ ) northeast of Feature A (Figure 9-2). These slabs appear to be the disturbed remains of a structure. A thin scatter of historic artifacts, consisting of construction debris such as rough nails, fence staples, and ceramic tile, is present around the sandstone slabs.

Feature $C$ (Figure 9-3) is a rectangular barren area measuring roughly $10 \times 13 \mathrm{~m}(3 \times 4 \mathrm{ft})$ which includes a concentration of eight partially buried concrete blocks oriented at various angles. The Feature $\mathrm{C}$ concrete blocks have a broken and "tumbled" appearance, as if they were seriously disturbed. Shovel tests excavated near Feature C show that the concrete blocks extend underground and are fairly extensive. The concrete blocks were perhaps part of the concrete floor for a sinceremoved structure. The artifact scatter surrounding Feature $\mathrm{C}$ extends to the artifacts surrounding Feature B, $27 \mathrm{~m}(88 \mathrm{ft})$ to the west. 


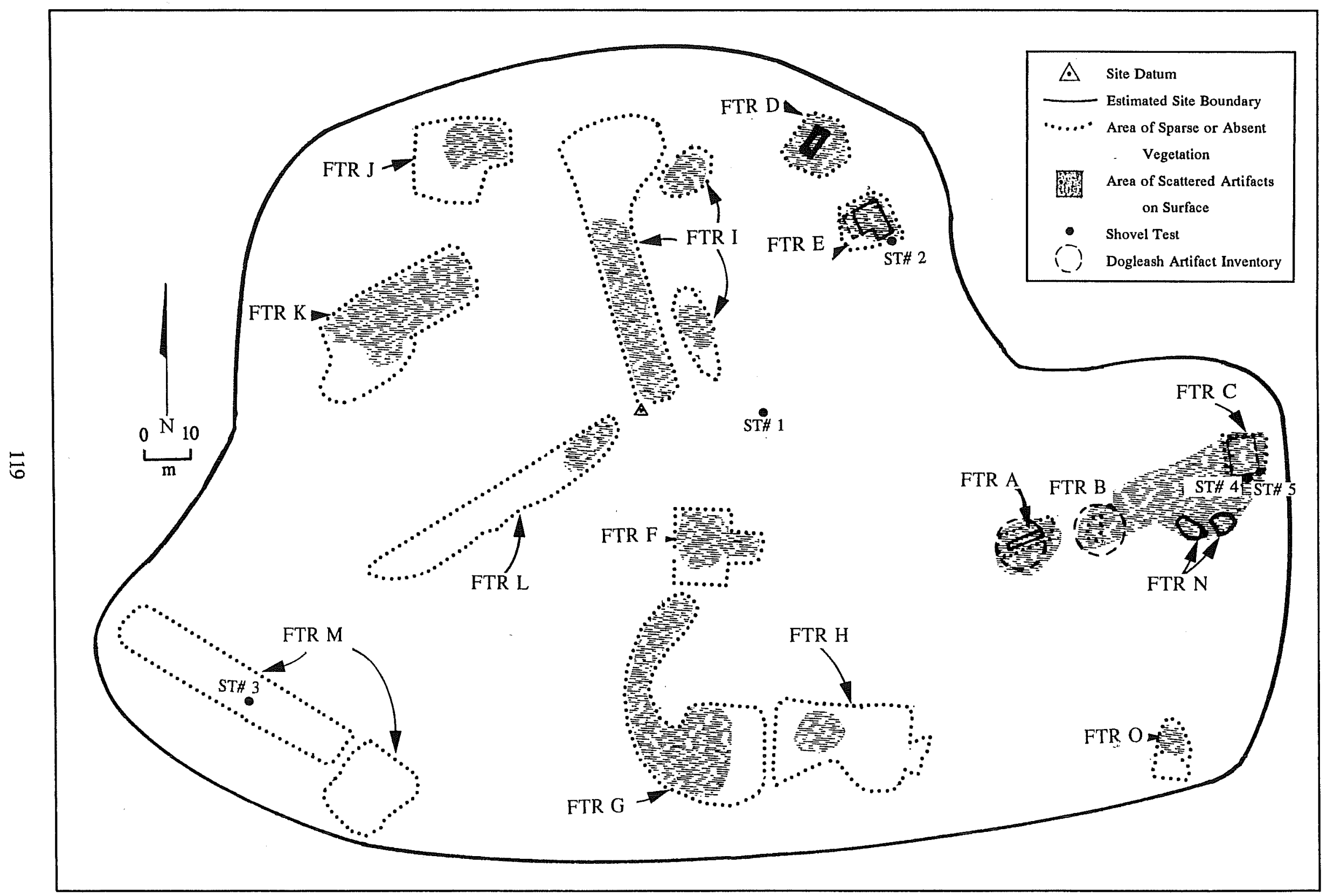

Figure 9-2. Site map, 41VV1682. 


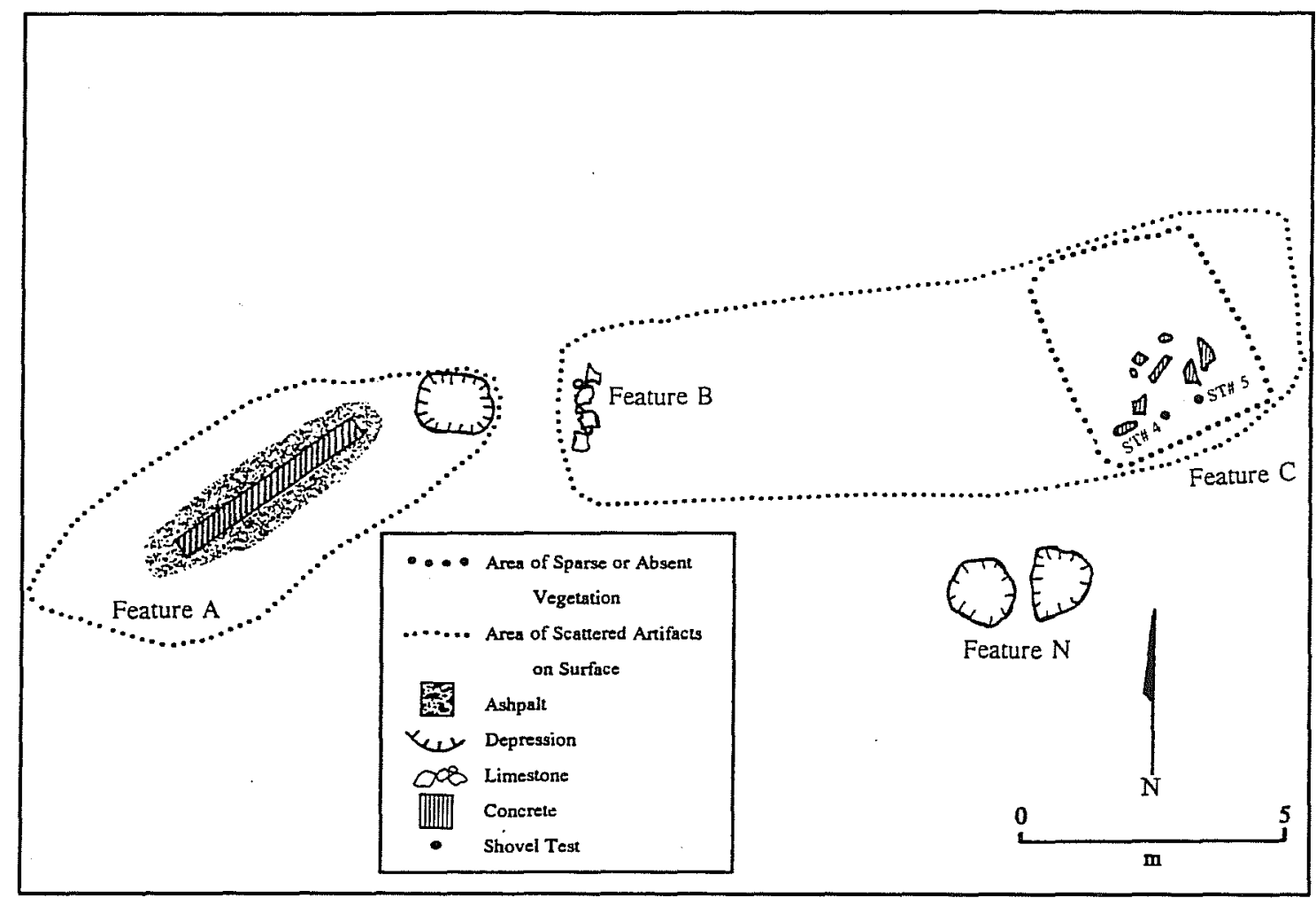

Figure 9-3. Features $A, B, C$, and $N$, site $41 V V 1682$.

Feature D (Figure 9-4) includes a buried concrete foundation, measuring about $3 \times 5 \mathrm{~m}(10 \times 16 \mathrm{ft})$. This feature appears as a sharply defined, rectangular, barren area in the grassy field. Because a subsurface structure was suspected to be present, a small trowel test was dug near the southwest corner. At $3 \mathrm{~cm}$ ( 1 inch) below the modern ground surface, a concrete foundation measuring $45 \mathrm{~cm}$ (18 inches) wide and flanked by the remains of wooden framing forms was uncovered (Figure 9-4 inset). Within and around the feature, construction debris is fairly dense and includes brick, rough ceramic tile, ceramic insulators, nails, rebar, and concrete fragments.

Feature E (Figure 9-5) is an L-shaped structural foundation which measures approximately $7 \times 5 \mathrm{~m}$ $(23 \times 16 \mathrm{ft})$ north-south with the base extending $1.7 \times 4.5 \mathrm{~m}(5.5 \times 15 \mathrm{ft})$ to the east. The foundation consists of lines of small limestone and concrete blocks which form the outline of an L-shaped structure. They occur in a vegetatively barren area measuring roughly $8 \times 15 \mathrm{~m}(26 \times 50 \mathrm{ft})$. Some of the foundation blocks are tilted or out of line, as though they have been disturbed. A thin scatter of artifacts, mostly construction debris, is associated with the Feature E barren area.
With the exception of Feature $\mathrm{N}$, the remainder of the designated site features are in areas in which the vegetation is either nonexistent or very sparse. These areas are generally rectangular in outline, although L-shaped and circular or curved areas are also present (Figure 9-2). Unlike Features D and E (and possibly also Features $B$ and $C$ ), not all these barren areas appear to represent structural foundations. Instead, some of these features may indicate areas where caliche, gravel, and other materials were packed down to form a kind of pavement, either for the floor of structures, or as a relief from the muddy conditions prevalent in barnyards and corrals. Alternatively, certain of these features may represent disturbance from military training exercises that included the use of heavy machinery.

Feature $F$ designates a rectangular area of sparse vegetation, measuring about $16 \times 11 \mathrm{~m}(52 \times 36 \mathrm{ft})$, with a square-shaped extension, approximately $7 \times 7$ $\mathrm{m}(23 \times 23 \mathrm{ft})$ off the eastern side (Figure 9-2). An associated artifact scatter consists mainly of nails and miscellaneous bits of metal. 


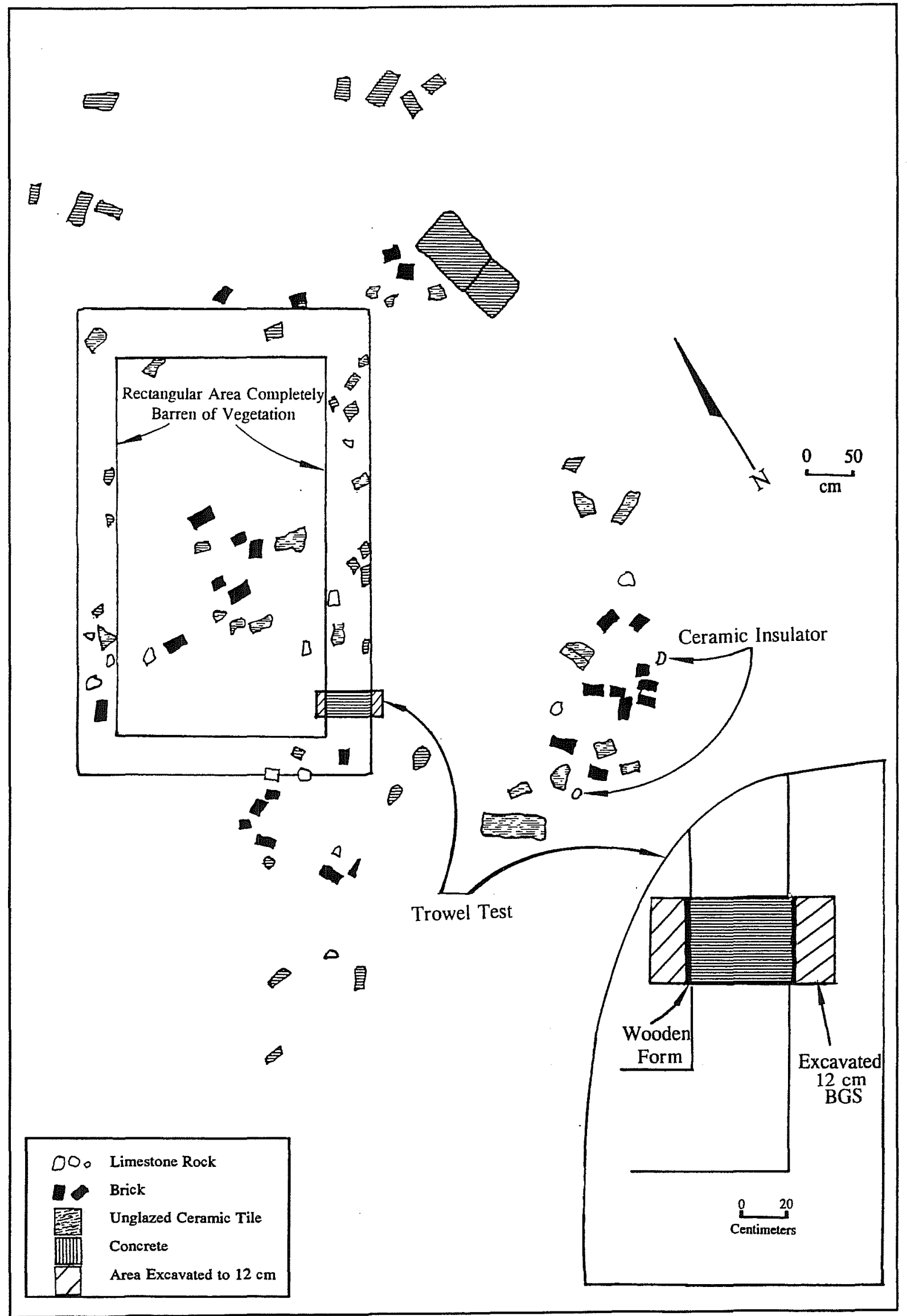

Figure 9-4. Feature D, site 41VV1682. 
Feature $G$ denotes a roughly rectangular area, approximately $10 \times 20 \mathrm{~m}$ ( $33 \times 66 \mathrm{ft}$ ) across, with sparse vegetation. The area has a long "tail," approximately $4 \mathrm{~m}$ (13 ft) wide, extending out of the western side and curving toward the north, almost to Feature F (Figure 9-2). Near the northeastern corner of the rectangular area is a concrete block, measuring approximately $0.5 \times 0.3 \mathrm{~m} \mathrm{(20x}$ 12 inches), which is level with the modern ground surface. An artifact scatter associated with Feature $G$ includes nails, concrete fragments, bailing wire, tin can fragments, and bottle glass.

Feature $\mathrm{H}$ is a roughly rectangular area of sparse vegetation, measuring approximately $28 \times 18 \mathrm{~m}$ $(91 \times 59 \mathrm{ft}$ ). A small concrete slab is situated near the northwestern corner of the feature. Feature $\mathrm{H}$ is located immediately east of Feature $G$ and may actually be a part of it, although a strip of vegetation is situated between them (Figure 9-2). Only a thin scatter of nails and miscellaneous metal pieces is associated with Feature $\mathrm{H}$.

Feature $I$ is a long, narrow area, measuring approximately $60 \times 8-9 \mathrm{~m}(200 \times 29 \mathrm{ft})$, almost barren of vegetation (Figure 9-2). The site datum is located at the southwestern corner of this feature. The northern end of Feature I extends eastward to a roughly circular area of sparse vegetation approximately $20 \mathrm{~m}(66 \mathrm{ft})$ in diameter. Southeast of this circular area is another smaller, roughly circular area of sparse vegetation. Another long, narrow (approximately $7 \times 20 \mathrm{~m}$ or $22 \times 65 \mathrm{ft}$ ) area of sparse vegetation extends parallel to the southern end of Feature I. The ground surface within Feature I is composed of gravel and hard-packed caliche and asphalt chunks mixed with the silty clay loam sediment which forms the surface of most of site 41VV1682; the ground surface is almost paving-like in appearance and density, and few plants have been able to colonize the area. Feature L (described below), which is oriented at a right angle to Feature I, has a similar ground surface. These are the only two site features that appear to have this gravel/ caliche/asphalt "paving."

Feature $\mathrm{J}$ designates a roughly L-shaped area of sparse vegetation located in the northwestern part of

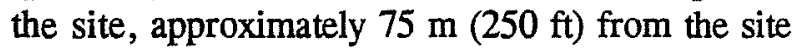
datum (Figure 9-2). This area measures $17 \times 20 \mathrm{~m}$ $(55 \times 65 \mathrm{ft})$. A very thin scatter of artifacts, consisting of brick and nails, is present within Feature $\mathbf{J}$.

Feature $\mathrm{K}$ denotes a rectangular area of sparse vegetation with a small, roughly circular area, also sparse in vegetation, located along the southern edge of the rectangle (Figure 9-2). The rectangular area measures approximately $20 \times 35 \mathrm{~m}(66 \times 115 \mathrm{ft})$. The circular area measures $10 \times 20 \mathrm{~m}(33 \times 66 \mathrm{ft})$ in diameter. A very thin artifact scatter consisting of nails and miscellaneous metal fragments is concentrated mainly within the rectangle of Feature $\mathrm{K}$.

Feature $\mathrm{L}$ is a long, narrow, rectangular area barren of vegetation. This feature is adjacent and similar to Feature I (Figure 9-2). Like Feature I, Feature L measures approximately $60 \times 8 \mathrm{~m}(200 \times 26 \mathrm{ft})$ and consists of heavy concentrations of gravel, caliche, asphalt fragments, and small concrete chips on the ground surface. The northern end of Feature $L$ is located approximately $2 \mathrm{~m}(6.5 \mathrm{ft})$ southwest of the 41VV1682 site datum and the feature extends almost at a right angle to Feature $\mathrm{I}$.

Feature $M$ is a long, narrow area of reduced vegetation. It lies near the southwestern edge of the

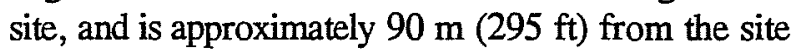
datum (Figure 9-2). The feature measures about $70 \times 10 \mathrm{~m}(229 \times 33 \mathrm{ft})$. At the southeastern end, the feature expands to form an L-shape; this part of the

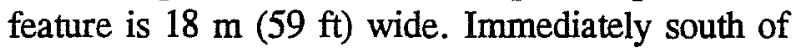
the L-shaped extension is a cluster of three small limestone slabs set at ground level. Artifacts scattered within Feature $M$ include undecorated whiteware, tin can fragments, lumber fragments, metal springs, a carburetor screen, and miscellaneous metal fragments.

Feature N (Figure 9-3) is two roughly circular depressions, together measuring approximately $4 \times 2 \mathrm{~m}$ $(13 \times 6.5 \mathrm{ft}$ ). The depth of the southeastern end of the depression is approximately 25 to $30 \mathrm{~cm}$ (10 to 12 inches), the depth of the northwestern end is approximately $20 \mathrm{~cm}$ ( 8 inches). Feature $\mathrm{N}$ is located

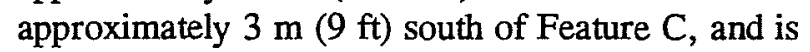
approximately $120 \mathrm{~m}$ (393 ft) east of the site datum (Figure 9-2). This feature may be a filled privy or well. A sparse artifact scatter present around the feature consists of tin cans, brick, and broken limestone. 
Feature O (Figure 9-6) is an irregular area with sparse vegetation, some gravels, and concrete and small limestone slabs which appear highly disturbed. This feature measures approximately $8 \times 11 \mathrm{~m}(26 \times 36 \mathrm{ft})$ and is located at the southeastern edge of the site.

\section{Dogleash Inventories}

Two dogleash artifact inventories, each $10 \mathrm{~m}$ in diameter, were conducted at site 41VV1682 (Figure 9-2). Dogleash Unit \#1 was located within and immediately outside of Feature A, which appeared to be the area of highest artifact density within the site. Dogleash Unit \#2 was located near Feature $B$, which was judged to be an area of more moderate or typical artifact density. Table 9-2 lists the artifacts from these inventories.

\section{Subsurface Testing}

Five shovel tests (STs 1-5) were excavated within site 41VV1682 (Figure 9-2). ST 1 was located $25 \mathrm{~m}(82 \mathrm{ft})$ due east of the datum. No features were apparent within the immediate vicinity of this shovel test, although the vegetation was somewhat sparse. Beneath the modern ground surface was a $12-\mathrm{cm}-$ (4.75-inch-) thick layer of caliche fill. Below this was a layer of hard-packed

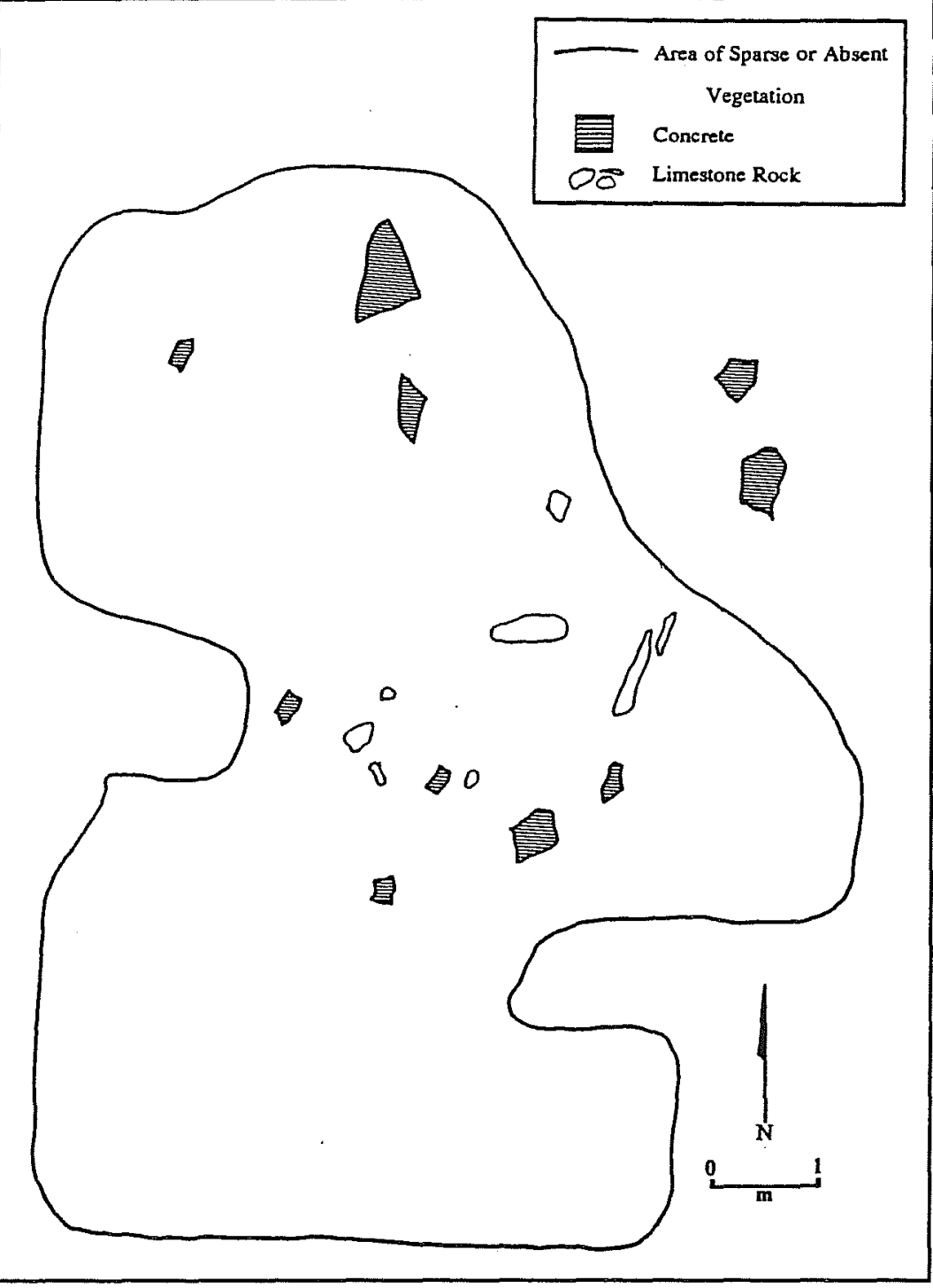

Figure 9-6. Feature $O$, site 41 VVI682. light brown silty clay extending to $50 \mathrm{~cm}$ (20 inches). No artifacts were recovered from this shovel test.

ST 2 was $2 \mathrm{~m}(6.5 \mathrm{ft})$ east of the eastern edge of the foundation of Feature $E$ (Figure 9-2). A wire nail was recovered from the upper $10 \mathrm{~cm}$ (4 inches); no other artifacts were recovered from this shovel test. The soil was a uniform light brown silty clay identical to the lower level of the first shovel test, to a depth of $50 \mathrm{~cm}$ (20 inches) below the modern ground surface.

ST 3 was located within the central part of Feature M (Figure 9-2). The uppermost layer extended to a depth of $2 \mathrm{~cm}$ (.8 inches), and was a light brown silty clay. The underlying sediment extended from 2 to 25 $\mathrm{cm}$ (.8 to 10 inches) in depth, and was a layer of reddish clay mixed with caliche containing approximately 60 to 70 percent pea- to golfball-sized gravels.

Between 25 to $40 \mathrm{~cm}$ (10 to 15.7 inches) in depth was an extremely hard-packed, light brown silty clay. Excavation was discontinued at a depth of 40 $\mathrm{cm}$ (15.7 inches) due to difficulty in excavating the hard-packed sediment within the confines of a shovel test. No artifacts were recovered in this shovel test.

ST 4 was located immediately east of the tumbled concrete blocks within Feature C (Figure 9-2). A piece of rebar extending beyond the limits of the shovel test was uncovered at a depth of $1 \mathrm{~cm}(.4$ inches). Another piece of rebar and a concrete block larger than the test hole was uncovered at a depth of 
2 to $4 \mathrm{~cm}$ (.8 to 1.6 inches); the concrete block was sloping down-ward from west to east.

ST 5 was placed $1 \mathrm{~m}(3.3 \mathrm{ft})$ north of the fourth shovel test (Figure 9-2) to determine if additional concrete was present. Fragments of barbed wire and mortar and a piece of rebar were encountered in the upper $10 \mathrm{~cm}$ (4 inches) of this fifth shovel test. At a depth of $11 \mathrm{~cm}$ (4.3 inches), the top of a large fragment of concrete embedded with barbed wire was uncovered. This shovel test was stopped at $20 \mathrm{~cm}$ ( 8 inches) because the entire unit was filled with concrete blocks at that depth. The concrete appeared disturbed, with its flat surfaces oriented at various angles. Generally, the shovel tests confirmed that Feature $\mathrm{C}$ contained concrete chunks which may have once been part of a larger slab that was seriously disturbed.

\section{DISCUSSION}

Due to the disturbed nature of 41VV1682, the sparsity of surface artifacts, and the lack of subsurface deposits, we recommend that site 41VV1682 not be considered eligible for nomination to the NRHP. Chapter 12 provides a fuller discussion of this recommendation.

The prehistoric component of site 41VV1654 is recommended as eligible for nomination to the NRHP (see Chapter 5). Further testing of Feature C, the earlier historic component, is recommended. However, no further research is recommended for the historic water troughs at 41VV1654 (Features D and E) associated with the ranching occupation at 41VV1682.

Table 9-2. Dogleash-Unit Inventory for Historic Site 41VV1682

\begin{tabular}{|c|c|c|}
\hline Artifact Type & $\begin{array}{c}\text { Dogleash } \\
\# 1\end{array}$ & $\begin{array}{c}\text { Dogleash } \\
\# 2\end{array}$ \\
\hline Wire nails & 33 & 7 \\
\hline Cut nails & 3 & 0 \\
\hline Tacks & 1 & 0 \\
\hline Fence staples & 1 & 2 \\
\hline Brick & 3 & 0 \\
\hline Ceramic tile & 0 & 1 \\
\hline Plaster & 10 & 0 \\
\hline Wire & 9 & 1 \\
\hline Window glass & 8 & 0 \\
\hline Washers & 1 & 0 \\
\hline Rubber & 1 & 0 \\
\hline Undecorated whiteware & 1 & 0 \\
\hline Pipe stems & 1 & 0 \\
\hline Bottle glass & 8 & 2 \\
\hline Misc. plastic & 1 & 0 \\
\hline Tin can fragments & 1 & 0 \\
\hline Misc. metal fragments & 6 & 1 \\
\hline Total & 88 & 14 \\
\hline
\end{tabular}




\section{Chapter 10. Historic Artifact Analysis and Discussion}

\section{Anne A. Fox and Cynthia L. Tennis}

Historic period artifacts and features were recorded at two sites on Laughlin Air Force Base, 41VV1654 and 41VV1682. The artifact assemblage consists of various types of construction materials and a small collection of domestic items (Table 10-1). These artifacts have been divided into four major categories for description: ceramics, bottle glass, other household objects, and building materials.

Table 10-1. Recorded and Collected Historic Artifacts

\begin{tabular}{||l|c|c|}
\hline \multicolumn{1}{|c|}{ Artifact Type } & 41VV1654 & 41VV1682 \\
\hline Undecorated white earthenware & 20 & 1 \\
\hline Decorated white earthenware-transfer print & 2 & \\
\hline Undecorated semi-porcelain and porcelain & 28 & \\
\hline Stoneware & 11 & \\
\hline Bottle glass & 121 & 10 \\
\hline Tin fragments & & 1 \\
\hline Misc. metal fragments & 2 & 7 \\
\hline Cut nails & 11 & 3 \\
\hline Wire nails & & 40 \\
\hline Window glass & 30 & 8 \\
\hline Cut limestone fragments & 2 & 102 \\
\hline Brick & 2 & 10 \\
\hline Tacks and staples & & 1 \\
\hline Plaster & & 1 \\
\hline Wire & & 1 \\
\hline Washers & & 1 \\
\hline Rubber & & 1 \\
\hline Ceramic tile & & 1 \\
\hline Mother-of-pearl fragments & & \\
\hline Slate & & \\
\hline Misc. plastic & & 10 \\
\hline Pipestem & & \\
\hline Totals & & \\
\hline
\end{tabular}




\section{ARTIFACT DESCRIPTIONS}

\section{CERAMICS}

Undecorated White Earthenware

This term is used to describe wares with a hard, cream to white paste covered with a bluish to clear glaze made throughout the late-eighteenth to early twentieth centuries, primarily in England and the United States. In the mid-nineteenth century, the popular taste changed to demand plain white, undecorated wares, sometimes called ironstone. Some ironstone was often one to two millimeters thicker than whitewares, but the difference between the earlier whiteware and the later ironstone is difficult to see and requires subjective judgments on the part of the analyst. For this reason, archaeologists presently tend to group all undecorated whitewares together (Miller 1993). Sherds of this type were found on both sites 41VV1654 and 41VV1682.

\section{Decorated White Earthenware}

Ceramics in popular use in Texas during the first half of the nineteenth century tended to have brightly colored decoration. The most popular choice for households of this time was decorated with transfer printing, most often in shades of blue (Dial 1992:41; Godden 1963:11). Two sherds of this type were found at site 41VV1654, none at 41VV1682.

Semi-Porcelain

Semi-porcelain or semi-vitreous porcelain, first produced in England around 1890 (Gates and Ormerod 1982:8), closely resembles white earthenware, but has a harder, more refined paste. Thus the paste resembles true porcelain, but is not translucent. This type of ceramic was popular during the last half of the nineteenth century in Texas. Twenty-eight sherds of this ware were found in Feature $C$ on site 41VV1654. No semi-porcelain was found on site 41VV1682.

\section{Porcelain}

This term usually refers to a thin, vitrified, translucent ware which produces a distinctive ring when tapped against a hard surface (Dial 1992:44; Godden 1963:31). It is more expensive than earthenware so usually only a few sherds of this ware are found on lower- and middle-class nineteenth-century sites. One sherd of this ware was collected from Feature $C$ on site 41VV1654, none from 41VV1682.
Stoneware

Stoneware is a dense, hard ceramic ware which can be various shades of tan to dark gray in color. The glazes used at various times during the nineteenth and twentieth centuries are helpful in determining the date of manufacture. Stonewares are generally used in the kitchen and pantry and were most popular at the end of the nineteenth and early twentieth centuries, before glass, metal, and then plastic kitchen wares became inexpensive and plentiful.

Albany slip glaze was used in the last half of the nineteenth century throughout the United States (Greer and Black 1971:4). The colors range from dark brown to shades of tan or green, depending on the source of the clay used for the slip. Salt glaze was used throughout the nineteenth century, up to about 1895 in the San Antonio area (Greer and Black 1971:5). Replacing salt glaze around 1900 was an opaque white Bristol glaze (Greer and Black 1971:6) which appealed to housewives as cleaner and easier to keep sanitary. Various combinations of these glazes appear on 11 stoneware sherds found on site $41 V V 1654$, suggesting an occupation period from the mid-nineteenth to the early twentieth century. Vessels represented by these sherds were probably crocks, churns, storage jars, and jugs. No stoneware was found on site 41VV1682.

\section{BOTTLE GLASS}

Various colors of bottle glass are represented in the collections. The glass from site 41VV1654 consists of 121 sherds of clear or purple-colored glass. A few sherds from brown and aqua bottles were found on the Zacatosa Ranch Headquarters site (41VV1682). Of these colors, the only ones useful for dating are those which turned purple after being exposed to sunlight. These were decolorized with manganese during the last quarter of the nineteenth century in order to render the naturally pale green color of glass clear for the popular market (Miller and Pacey 1985:44). Manganese was replaced by selenium around World War I, which turned a light amber with exposure to sunlight (Munsey 1970:55). Thus purple-colored glass is effectively dated to the period of approximately 1875-1915. 


\section{OTHER HOUSEHOLD OBJECTS}

A handle from a cast-iron frying pan labeled "9 in" (catalog number 41VV1654-038) is typical in design of those sold in the last quarter of the nineteenth century into the early twentieth century. A fragment of cast iron (catalog number 41VV1654-037) is identifiable as part of a shelf bracket, commonly sold by Sears and Roebuck during the last quarter of the nineteenth century. A similar one was found on a sheep ranch in Dimmit County (Fox and Cox 1983), dating to the $1870 \mathrm{~s}-1880 \mathrm{~s}$. Both of these objects were found on site 41VV1654. Fragments of tin cans were too small to identify as to method of construction. A lid from Clabber Girl Baking Powder tin can (catalog number 41VV1682-003) was found on site 41VV1682. A single fragment of slate from Feature A of site 41VV1654 (not collected) probably represents a writing slate. These were in popular use throughout Texas up to the early 1900 s, particularly in poorer neighborhoods.

\section{BUILDING MATERIALS}

The most useful building materials for comparative dating are nails, which underwent distinctive changes as manufacturing methods changed through time. Cut or square nails were in general use throughout Texas up until about 1900 , when they were replaced by wire nails such as are still in use today. It is interesting to note that all the nails from site 41VV1654 are cut nails, while those found on site 41VV1682 are both cut and wire nails.

Window glass was recorded at both 41VV1654 $(n=30)$ and 41VV1682 $(n=8)$. While theories have been suggested for dating window glass (Moir 1987; Roenke 1978), the small sample sizes from 41VV1654 and 41VV1682 do not permit this type of analysis.

Small quantities of brick and cut limestone were represented on site 41VV1654. Due to the extreme mechanical disturbance of the site, we were unable to determine elements of construction, such as foundations or chimneys. One diagnostic brick fragment was recovered from $41 \mathrm{VV} 1682$. It bears the manufacturing mark of the D'Hanis Brick and Tile Company in business in Medina County since 1905 . It also has the logo of the Common Brick Manufacturers Association (CBMA) that dates to after 1920 (Steinbomer 1983).

\section{VV1654}

The historic artifacts recorded from the early component, Feature C, at 41VV1654 represent types usually associated with domestic activities around a household. Seventy-nine percent of these $(n=174)$ are bottle glass and ceramic sherds, while only 21 percent $(n=47)$ are related to construction activities. The artifacts found at this site indicate it was occupied during the last half of the nineteenth century and the very first part of the twentieth. The presence of transfer-decorated earthenware sherds tends to push the date back to pre-Civil War times, but since only one such vessel appears to be present this could represent an heirloom (a piece from earlier times brought in by a settler). The large percentage of undecorated whitewares and semi-porcelain certainly establishes a beginning date in the last quarter of the nineteenth century, which is greatly strengthened by the presence of salt-glazed and Albany slipglazed stoneware, both common on late-nineteenthcentury sites. The presence of so much purplecolored container glass reinforces this estimate, as do the frying pan and shelf bracket. The absence of wire nails suggests a pre-1880s construction date for this site.

The material recovered reflects the time spans represented by the two historic components in 41VV1654 quite adequately. The presence of cut limestone and cut nails from the earlier component at 41VV1654 (Feature C) suggest a mid- to late-nineteenth-century date. The majority of the artifacts from Feature $\mathrm{C}$ were residential in character. Taken as a whole, this artifact collection presents a convincing case for identifying $41 \mathrm{VV} 1654$ as the abandoned house present near the creek when the Marshalls arrived (see Chapter 8). Features D and E are later components related to the $1920-1940$ s sheep ranching activities at $41 \mathrm{VV} 1682$, the Zacatosa Ranch headquarters. 
ZACATOSA RANCH HEADQUARTERS (41VV1682)

Of the 102 historic artifacts recorded in dogleash inventories at $41 \mathrm{VV} 1682,79$ percent $(n=81)$ are related to construction activities, over half of which are wire nails $(n=40)$. Bottle glass $(n=10)$ and miscellaneous metal fragments $(n=7)$ account for 81 percent of the non-construction related artifacts.

The presence of undecorated whiteware sherds and various colors of glass, plus wire nails and the D'Hanis brick, confirms that this site dates to post1920s. Unfortunately very few artifacts remain to reveal the uses of the various parts of the site, which indicates a rather complete eradication of the occupation level of the site, probably by mechanical means, at the time the buildings were removed.

The total change to concrete and concrete block foundations reflected by the features and the post1900 date of the few artifacts recovered from 41VV1682 combine to reinforce the identification this site as the Zacatosa Ranch headquarters.

In 1942 , at the time the ranch was acquired by the government, the headquarters consisted of a collection of buildings constructed for the housing and feeding of the ranch operators and laborers; buildings devoted to the care and feeding of the livestock; a water system based on a windmill, storage tank, and water troughs; and a Delco electric generating plant. In addition, a system of corrals of various types of construction was present. The headquarters was located in a flat, relatively open area in the surrounding brush. The descriptions and photographs of the various buildings provided below were found in the Appraisal Report in the Base Properties file at Laughlin AFB. Unfortunately, neither the photographs nor the other documents in the file indicate the layout of the buildings.

1. An adobe house, $24 \times 40 \mathrm{ft}$, with a screened porch, two brick stove chimneys, and a shingled roof on a concrete foundation, surrounded by a woven wire fenced yard (Figure 10-1).

2. A frame house, $24 \times 24 \mathrm{ft}$, with a pyramidal hipped roof and a 12-x-15-ft addition with flat roof, on a block foundation, surrounded by a woven wire fenced yard (Figure 10-2).
3. A "chuck house" or kitchen, $16 \times 24 \mathrm{ft}$, containing three rooms, of boxed construction, with shingled roof, on a block foundation (Figure 10-3), included within the yard of the frame house. Boxed construction uses no studs or crossbracing. The vertical wall planks, nailed to a sill below and a plate at the roof line, are all that holds up the roof. This type of construction came into use around the turn of the century (Rogers 1972:77-78).

4. A labor or bunk house, $12 \times 24 \mathrm{ft}$, of boxed construction, on a concrete foundation, with metal gabled roof, within a yard surrounded by a woven wire fence (Figure 10-4).

5. A garage, $12 \times 27 \mathrm{ft}$, of boxed construction, on a block foundation, with metal roof, located near the labor house (Figure 10-4).

6. A garage, $18 \times 36 \mathrm{ft}$, of boxed construction on a block foundation, with metal gabled roof (Figure 10-5).

7. A feed house, $20 \times 24 \mathrm{ft}$, of ironclad construction (wood frame with an iron skin), with metal gabled roof, on a concrete foundation (Figure 10-6).

8. A saddle house, $14 \times 15 \mathrm{ft}$, of boxed construction, with metal gabled roof, on a block foundation (Figure 10-7).

9. A sheep hospital, $12 \times 22 \mathrm{ft}$, of stud construction with metal shed roof, on a block foundation.

10. A storehouse, $12 \times 15 \mathrm{ft}$, of ironclad construction, with metal shed roof, on a block foundation (Figure 10-8).

11. A hen house, $8 \times 10 \mathrm{ft}$, of boxed construction, with metal roof, on a block foundation.

12. A house for a Delco generator, $6 \times 8 \mathrm{ft}$, of ironclad construction, with metal shed roof, on concrete foundation (Figure 10-9).

13. A system of corrals built of horizontal boards or stacked logs (Figure 10-10). Stacked log corrals were popular throughout the sheep raising country of south and west Texas (Fox and Cox 1983: Figure 3b). 


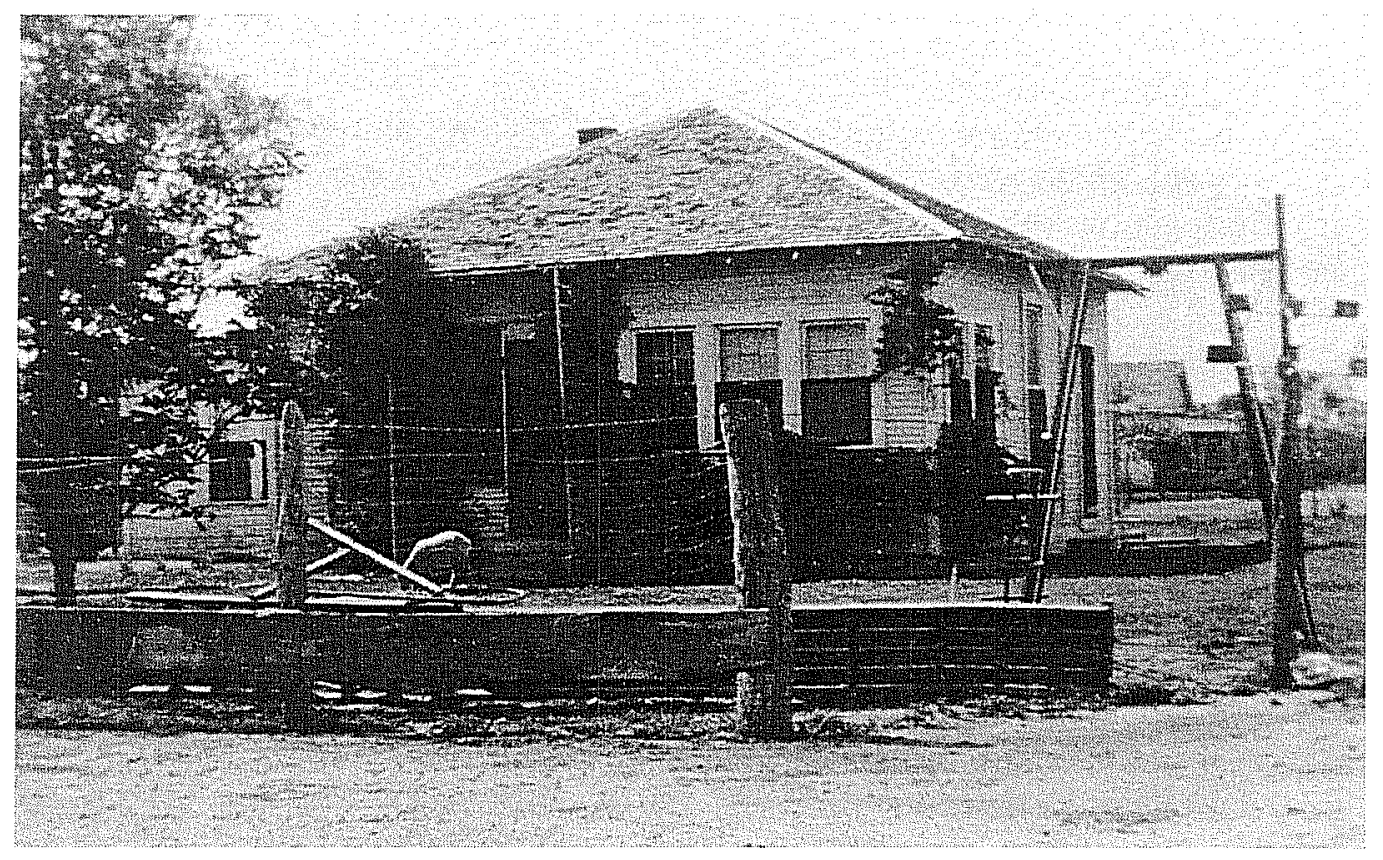

Figure 10-1. Adobe house, ca. 1942, looking southwest. Laughlin AFB Base Properties files.

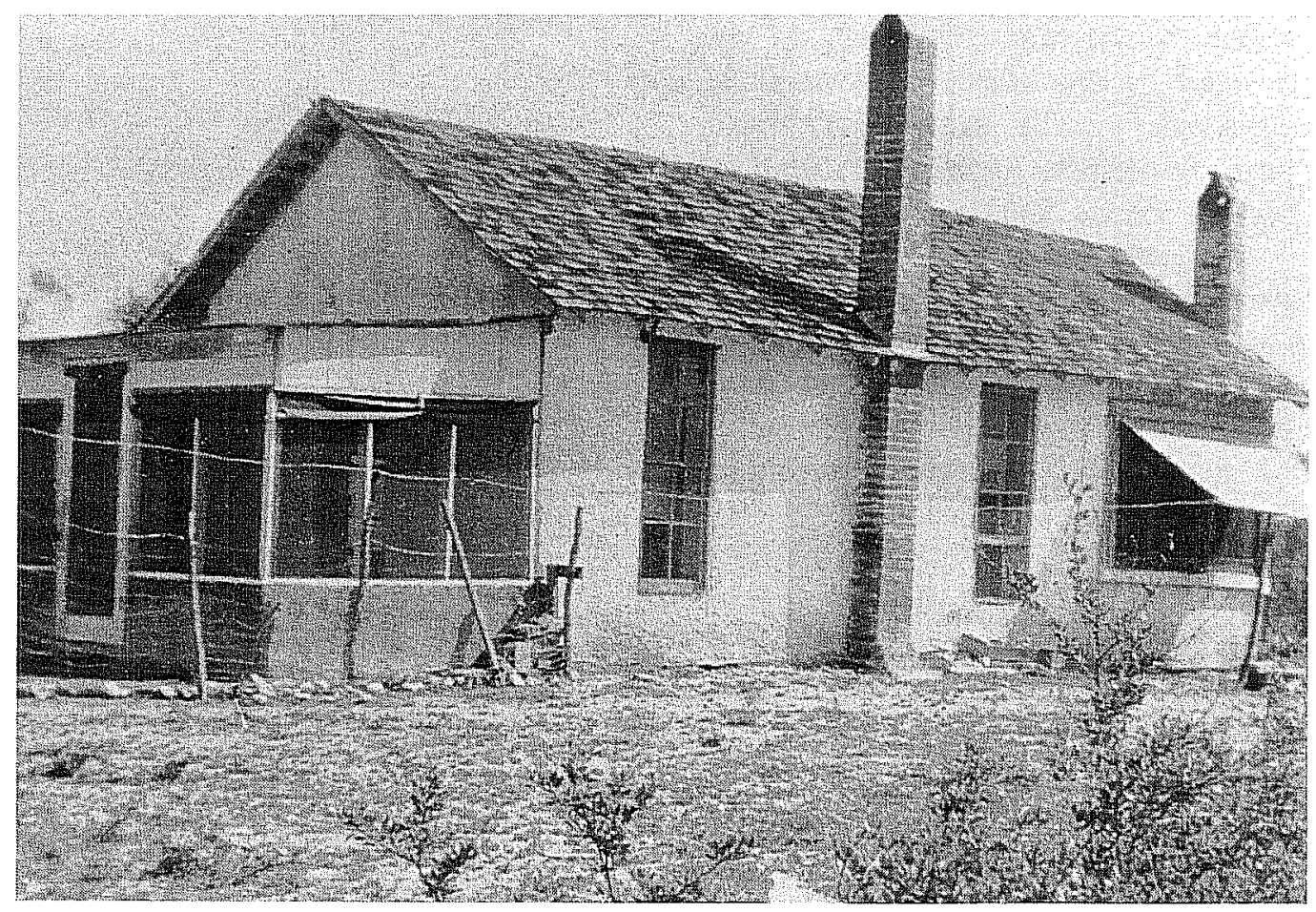

Figure 10-2. Frame house, ca. 1942, looking west. Note addition on left. Laughlin AFB Base Properties files. 


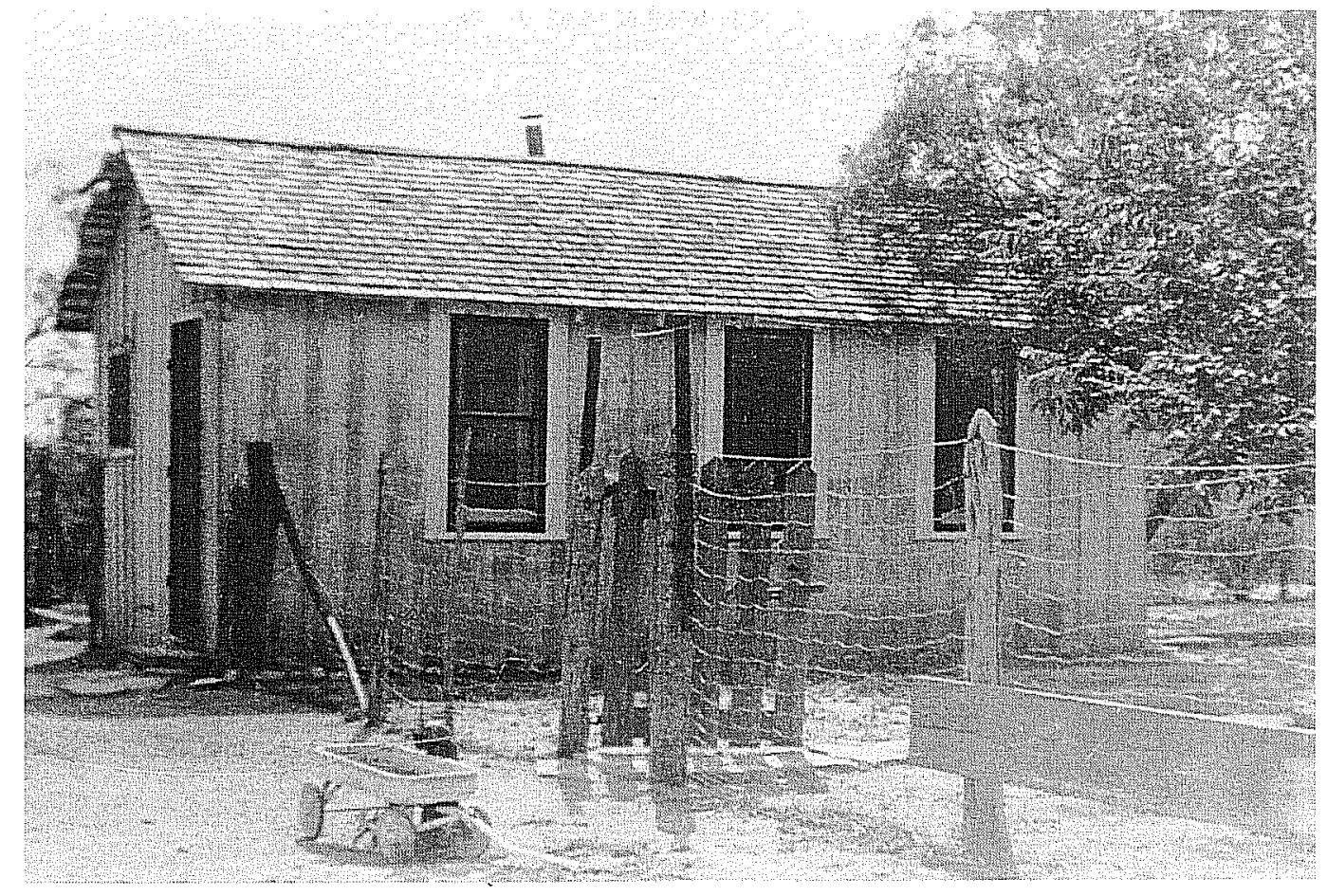

Figure 10-3. "Chuck house" or kitchen, ca. 1942, looking east. Laughlin AFB Base Properties files.

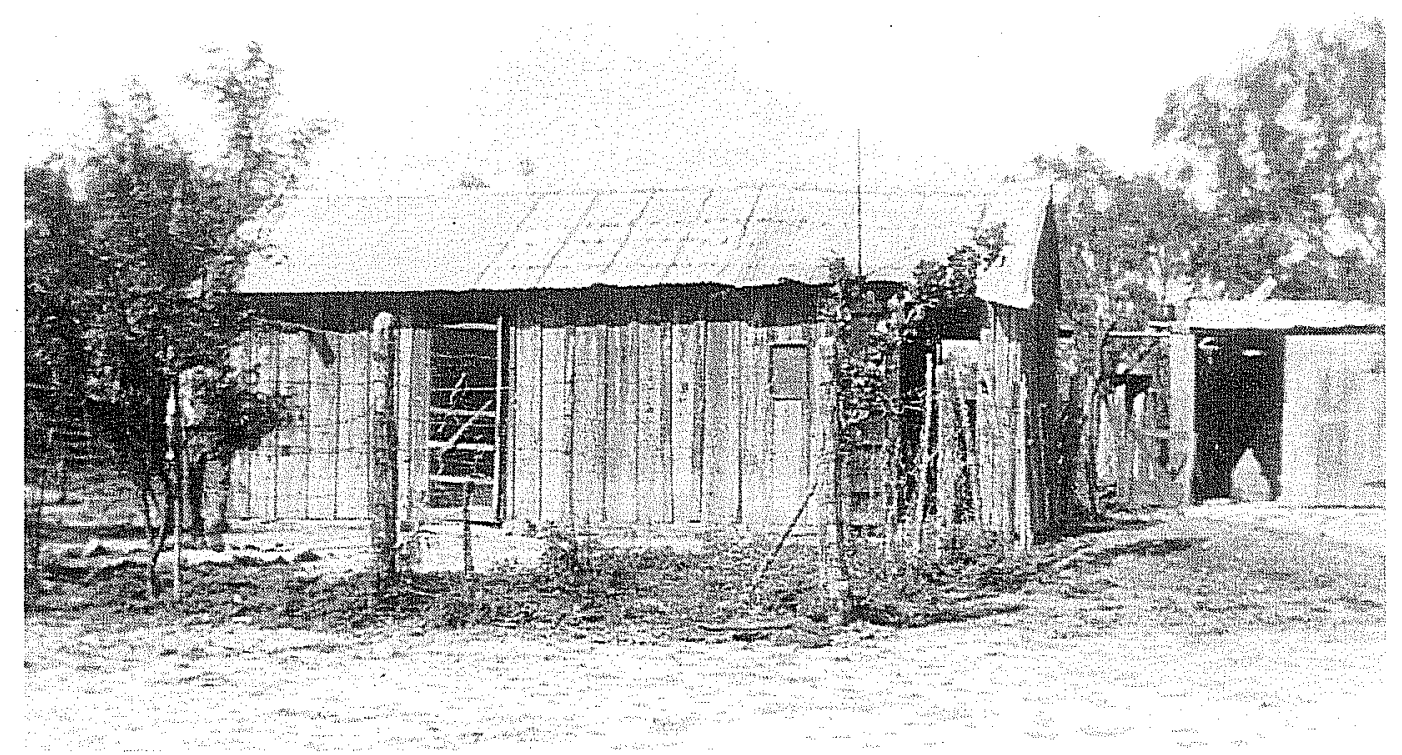

Figure 10-4. Labor or bunk house and garage (right), ca. 1942, looking west. Laughlin AFB Base Properties files. 


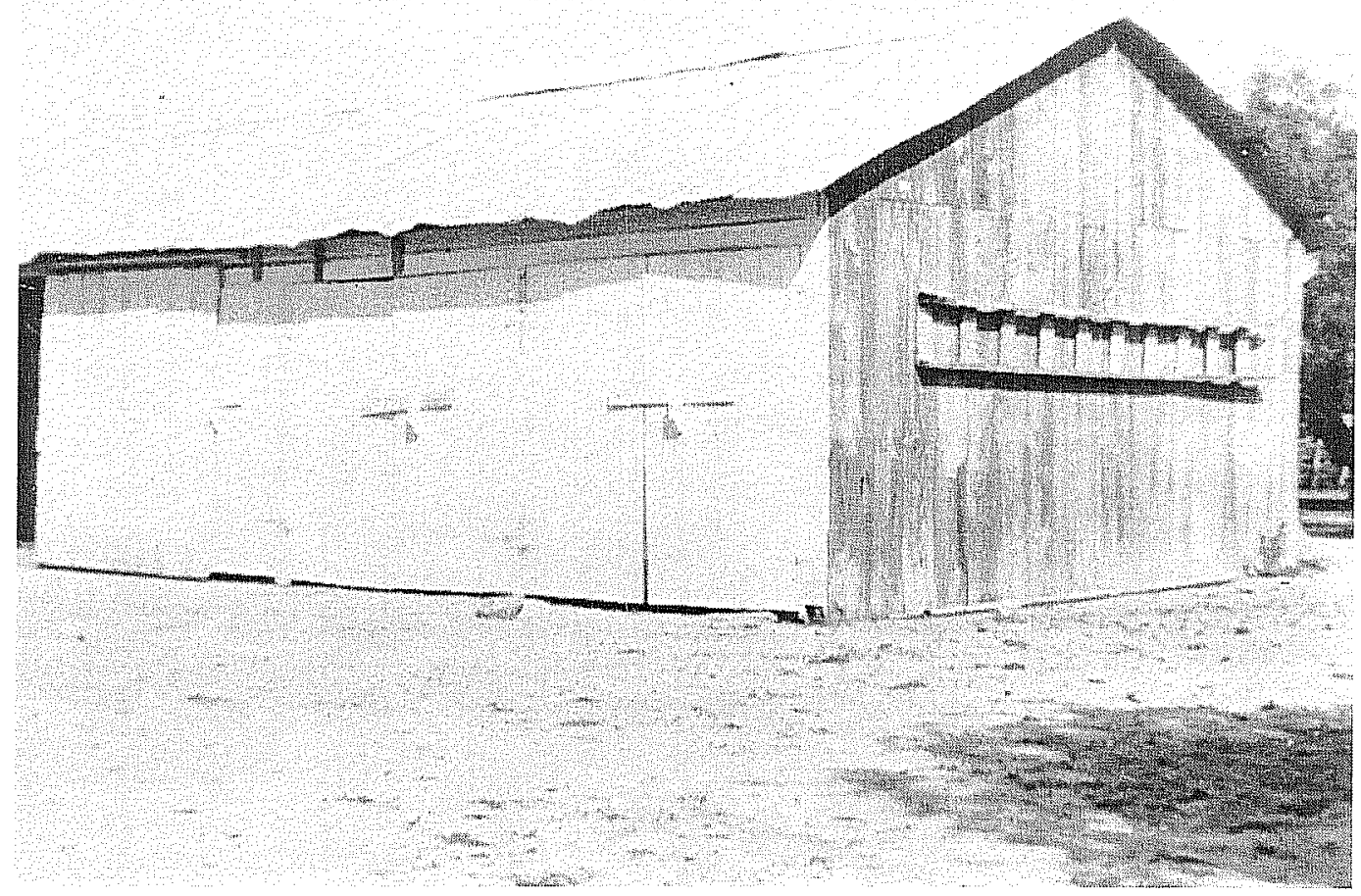

Figure 10-5. Garage, ca. 1942, looking east. Laughlin AFB Base Properties files.

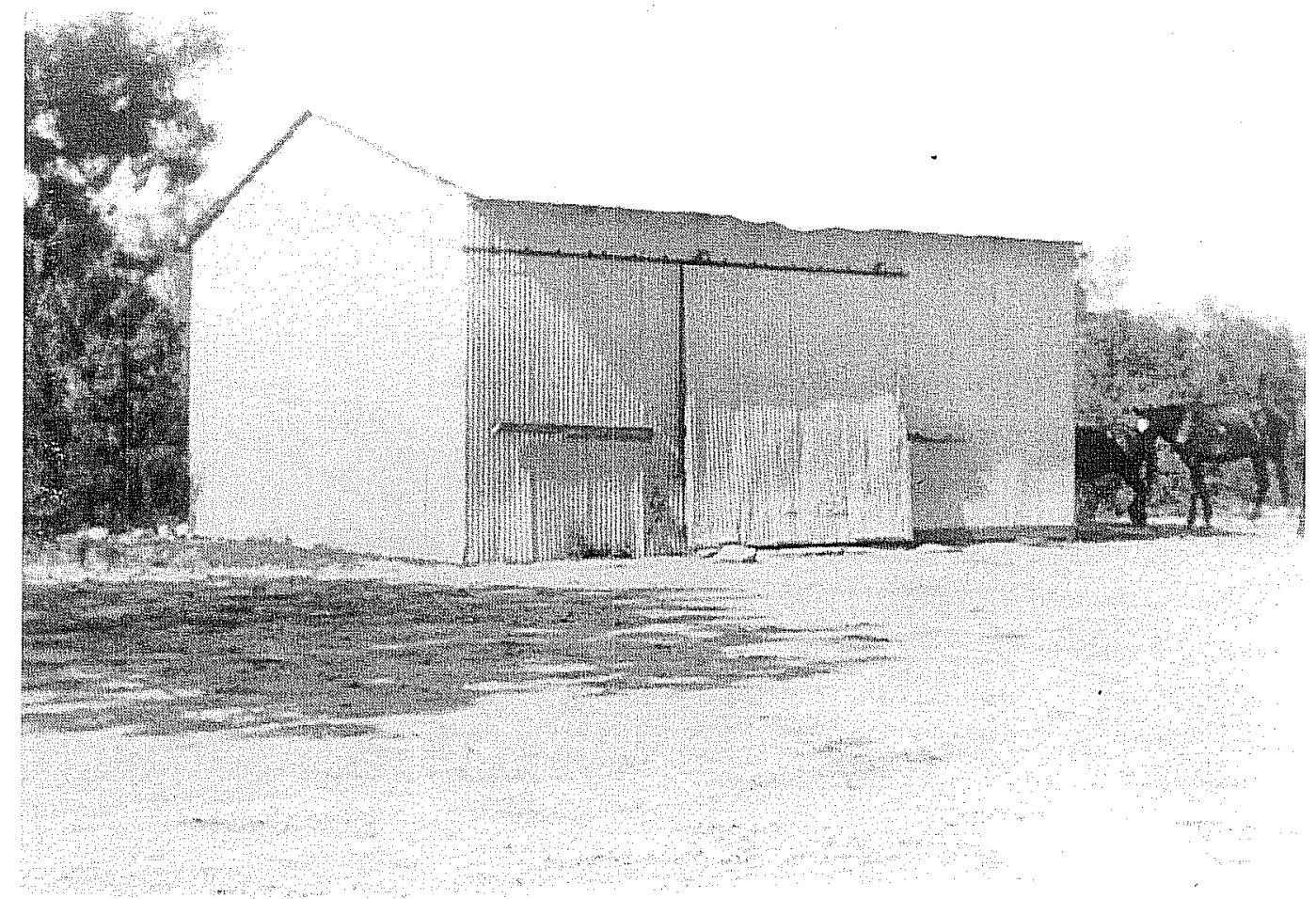

Figure 10-6. Feed house, ca. 1942, looking southwest. Laughlin AFB Base Properties files. 


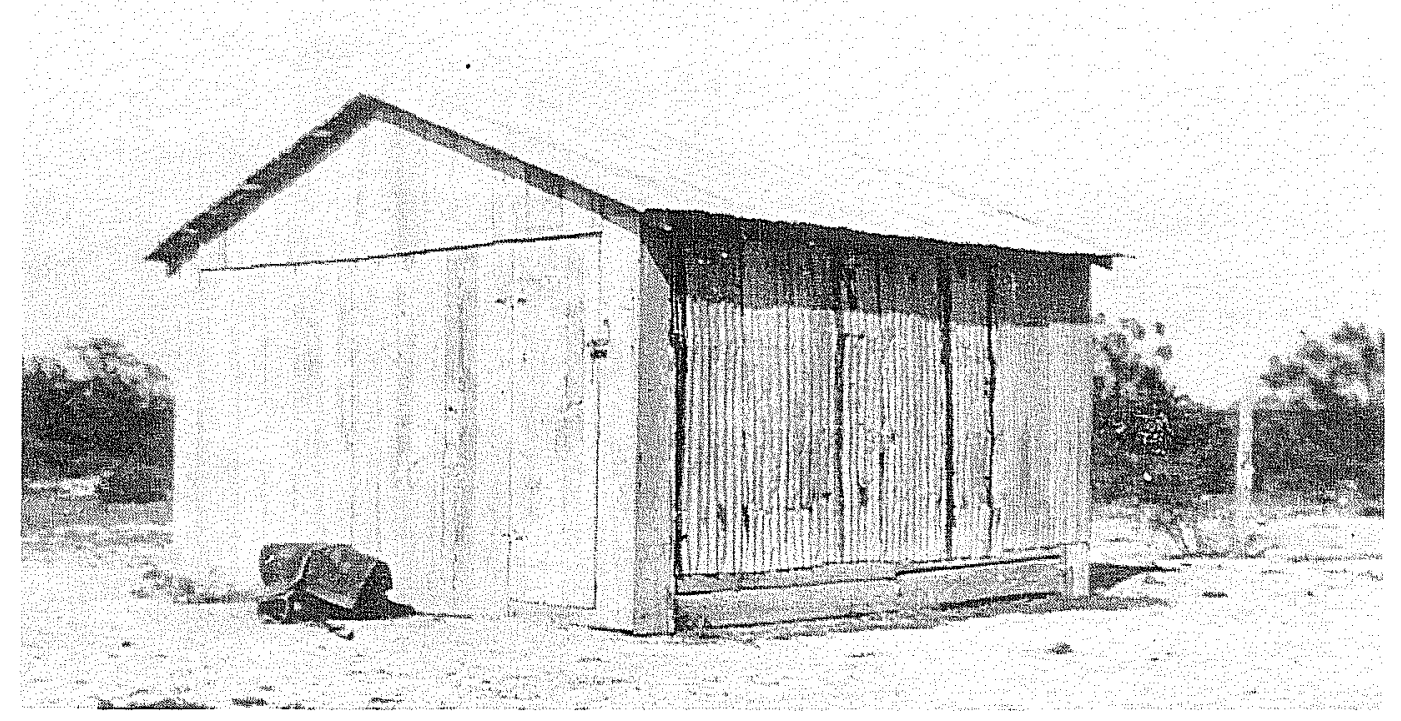

Figure 10-7. Saddle house, ca. 1942, looking southwest. Laughlin AFB Base Properties files.

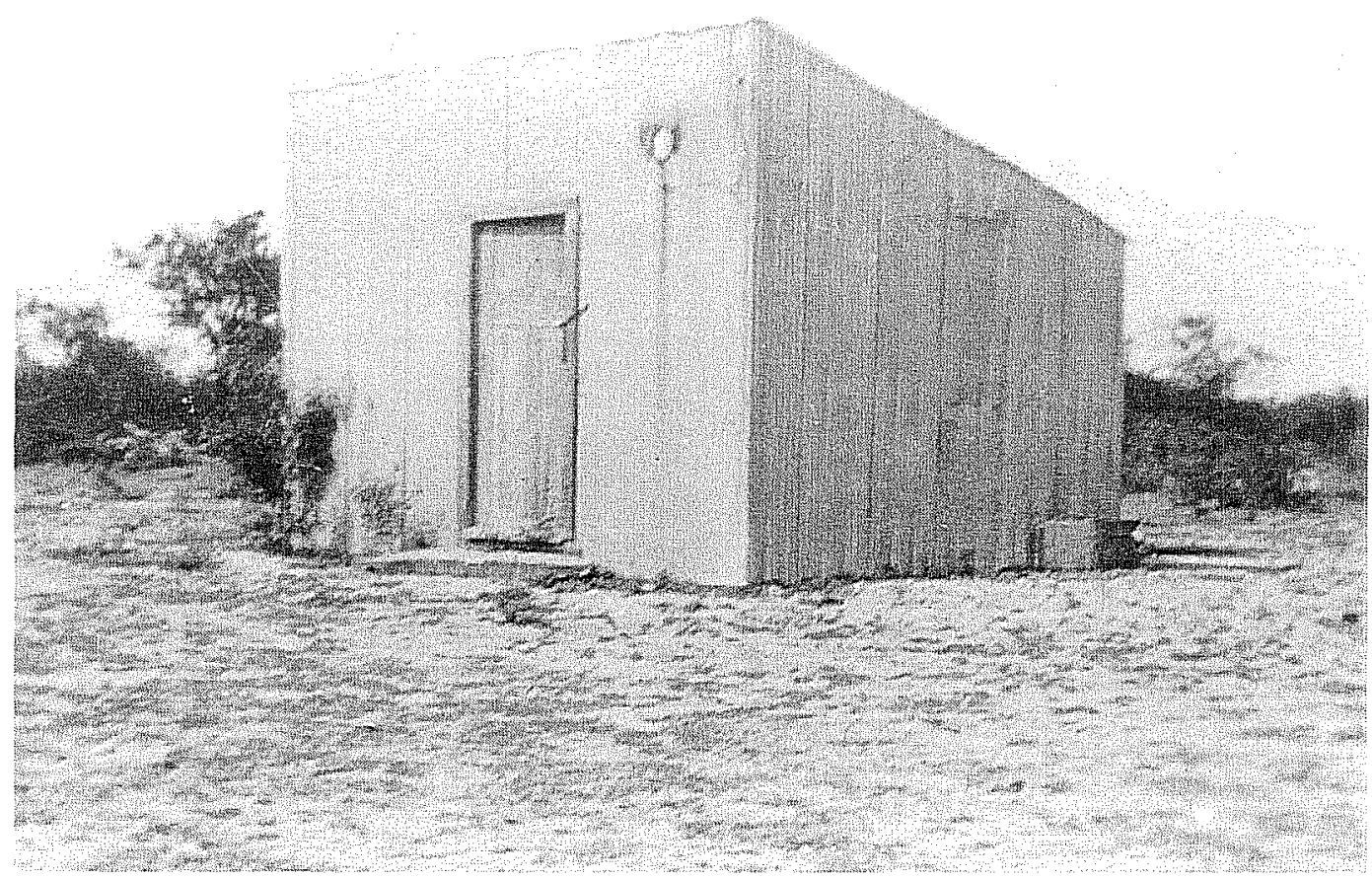

Figure 10-8. Storehouse, ca. 1942, looking southwest. Laughlin AFB Base Properties files. 


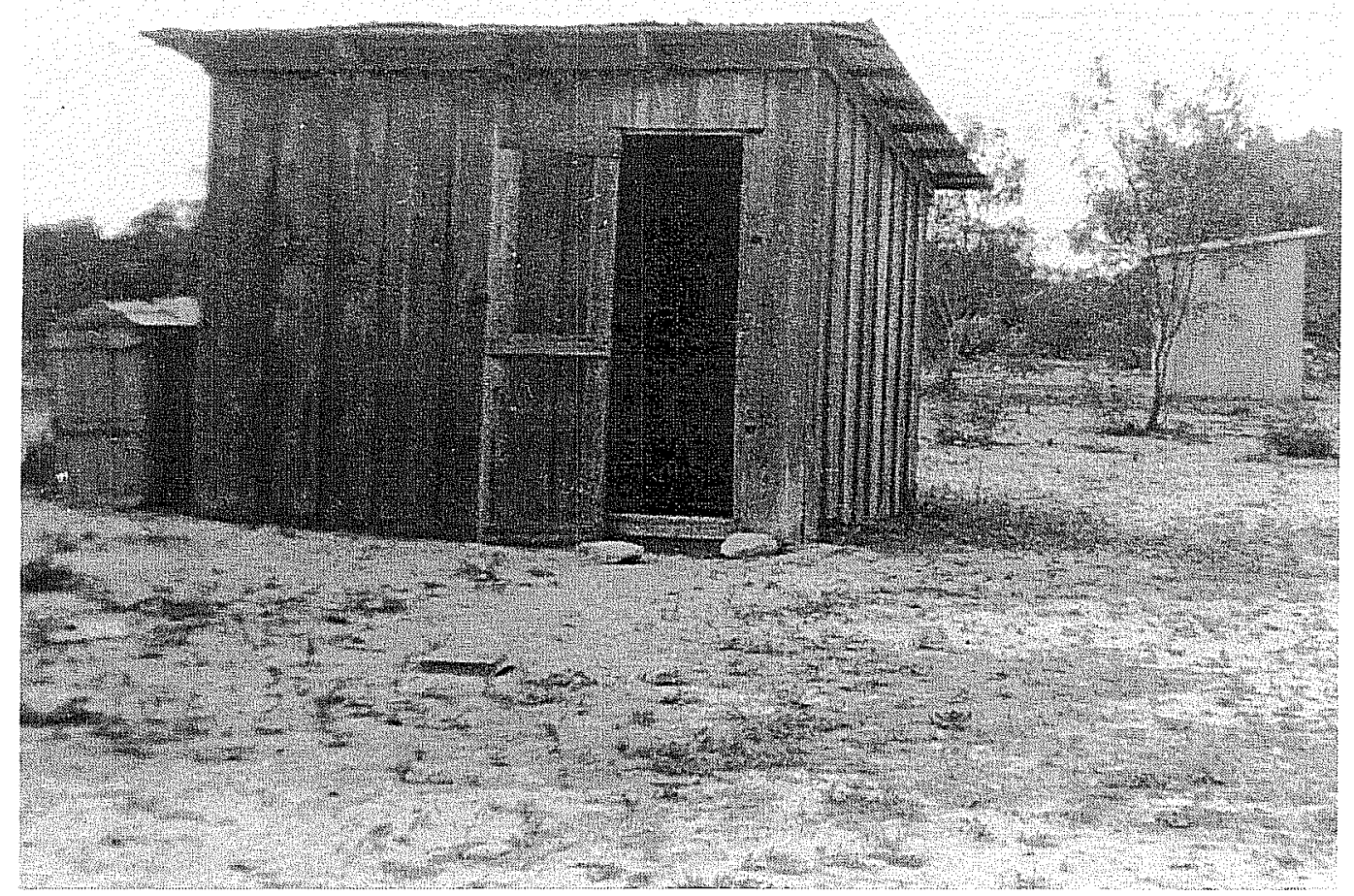

Figure 10-9. Delco generator house, ca. 1942, looking west. Laughlin AFB Base Properties files.

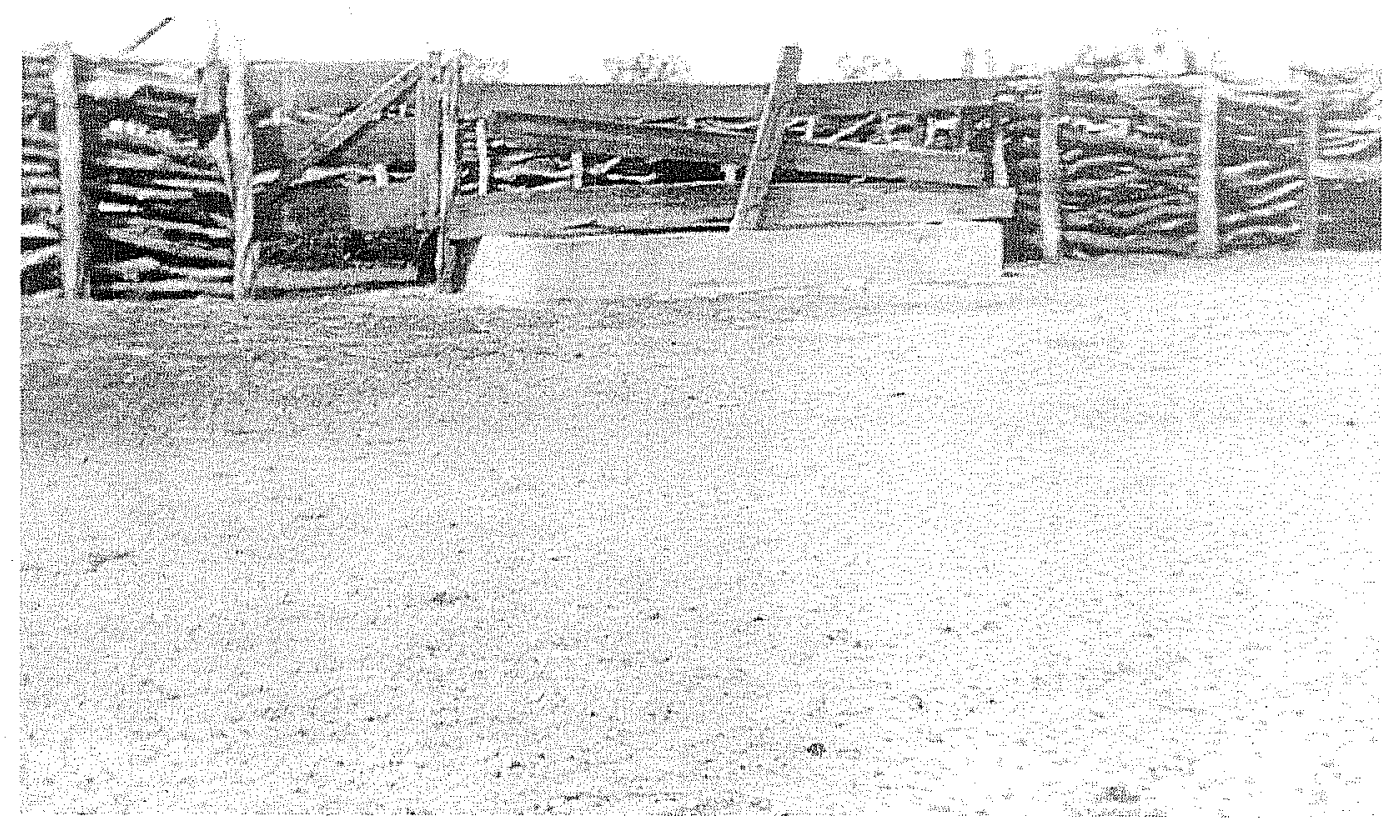

Figure 10-10. Corrals, ca. 1942, looking northwest. Laughlin AFB Base Properties files. 
14. A water system consisting of a well, a windmill, a concrete storage reservoir, and concrete water troughs.

Mr. Harrison received permission to move all these structures-except the adobe house, the smaller of the two garages, the generator house, and the corrals and water system-at the time the ranch was sold. However, according to Anselyn Marshall (personal communication 1994), only the frame house was relocated to the Marshall property south of the base. Apparently, many of the remaining structures were dismantled and hauled away and the area was then bladed and scraped level.

Fifteen features were recorded at 41VV1682. These are described in detail in Chapter 9 and include one sandstone and three concrete remnants of structure foundations, three concrete watering troughs, and 11 areas where the ground shows evidence of modification, either by structural foundations or occupational activities (Figure 9-2). Attempts to relate these features to specific structures at $41 \mathrm{VV} 1682$ can be nothing more than speculative, however, some observations are offered.

Feature A (Figure 10-11) at site 41VV1682 was a stock watering trough similar to the one shown in Figure 10-12. It probably was located somewhere near a residential structure, since nails, plaster, and window glass were found in direct association with it. However, the rather violent disturbance of the site could have carried these objects quite a distance before dumping them there. The feature is nearly identical to Features $D$ and $E$ at 41VV1654. On both sites, a circular depression nearby may have been the well that provided water. Each trough was surrounded by an asphalt pavement, which kept the animals from trampling the ground around it. The bolts set into the concrete at one end of the trough were used to attach a float mechanism for controlling the depth of the water.

Feature B, a row of flagstones, cannot be directly related to a known structure, since none of the structures on this site had stone foundations. This feature may have been a pathway. Feature C, $27 \mathrm{~m}$ east of Feature B (Figure 9-3), consisted of concrete blocks and measures approximately $10 \times 13 \mathrm{~m}$. Shovel tests near this feature suggest that it could represent a structure set on a concrete slab. Size and foundation type of the structure suggest it could represent the remains of the adobe house (Figure 10-1).

Feature E (Figure 9-5) represents an L-shaped structure on a concrete slab with limestone blocks, which matches the description and photographs of the ranch's main frame house and $12 \times 15 \mathrm{ft}$. addition (Figures 9-4 and 10-2). Feature D (Figure 10-13) is a buried concrete foundation, measuring roughly $3 \times 5 \mathrm{~m}$. Although the dimensions do not correspond exactly to any structure description we currently have, its location near Feature $\mathrm{E}$ and its concrete foundation do correspond with the "chuck house" structure (Figure 10-3) within the yard of the frame house.

The other features were too confused to even guess at identification. The artifacts associated with them, mainly nails and bottle glass, are typical of those

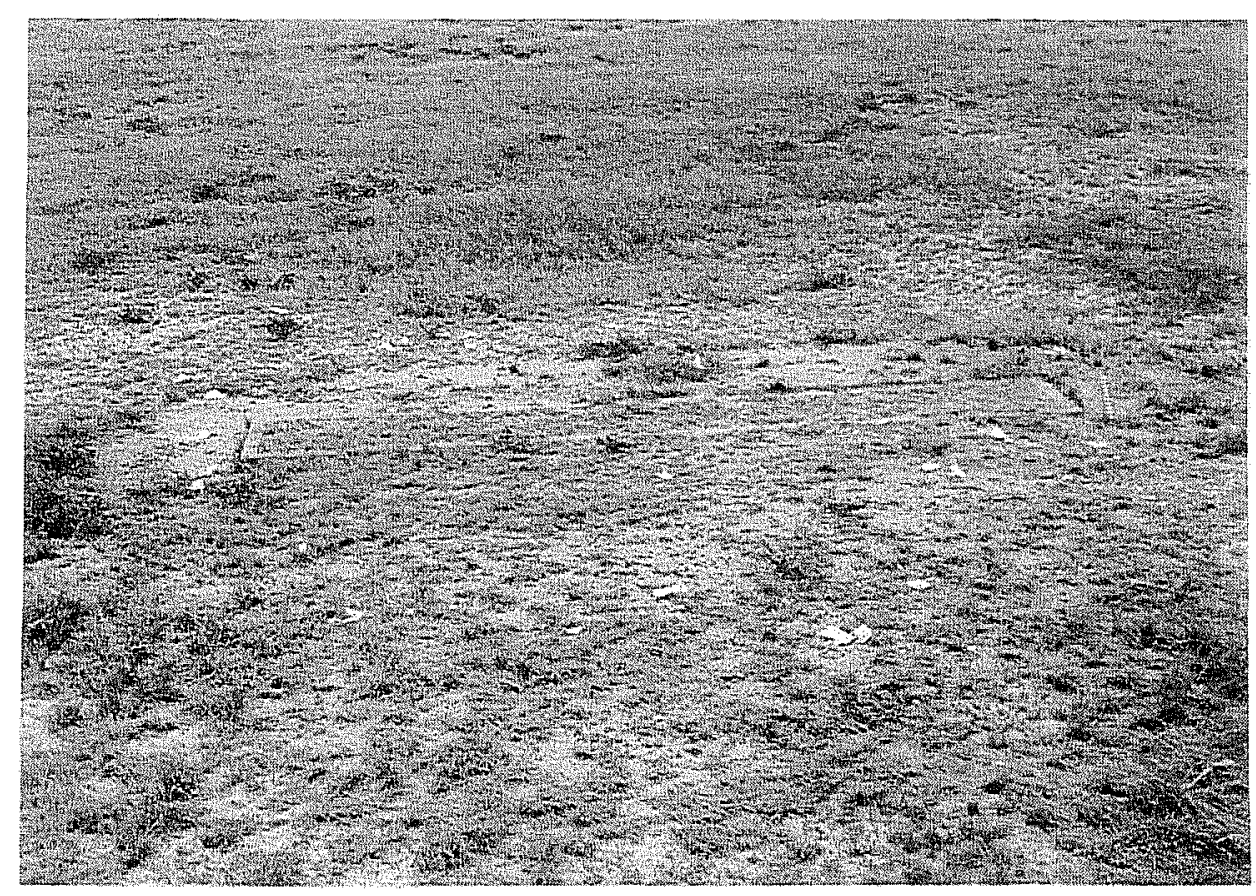

Figure 10-11. Feature A, site 41VV1682, looking north. 


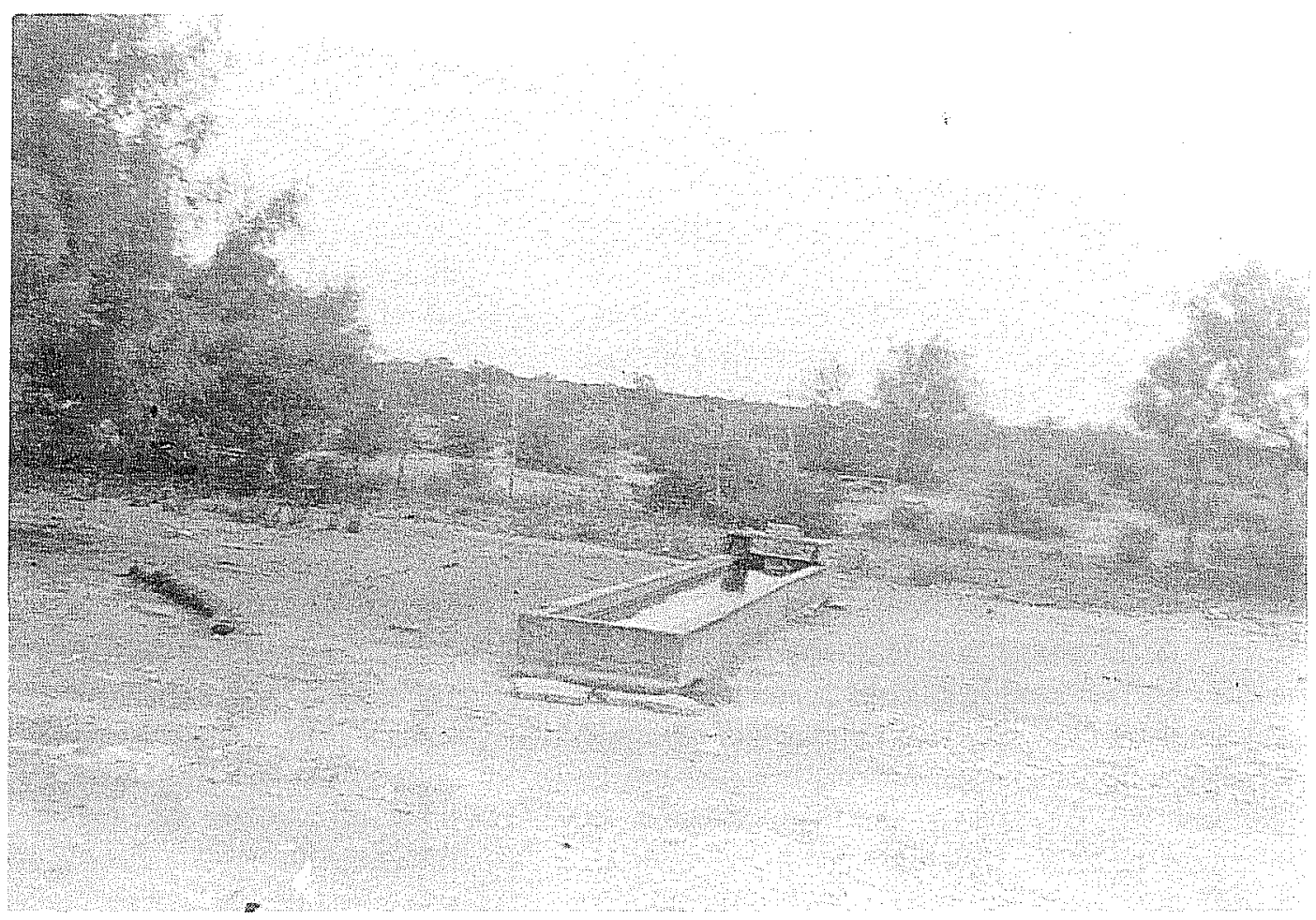

Figure 10-12. Watering troughs, west of ranch house, ca. 1942. Laughlin AFB Base Properties files.

found around twentieth century farm structures. Shovel tests within the site indicate that in some areas, a $12 \mathrm{~cm}$-thick layer of gravel and caliche fill may have been purposely laid over the clay base before the buildings were built. Similar site preparation is sometimes done on properties that are particularly difficult to deal with when wet. This type of underlayment is often also installed before pouring a concrete slab.

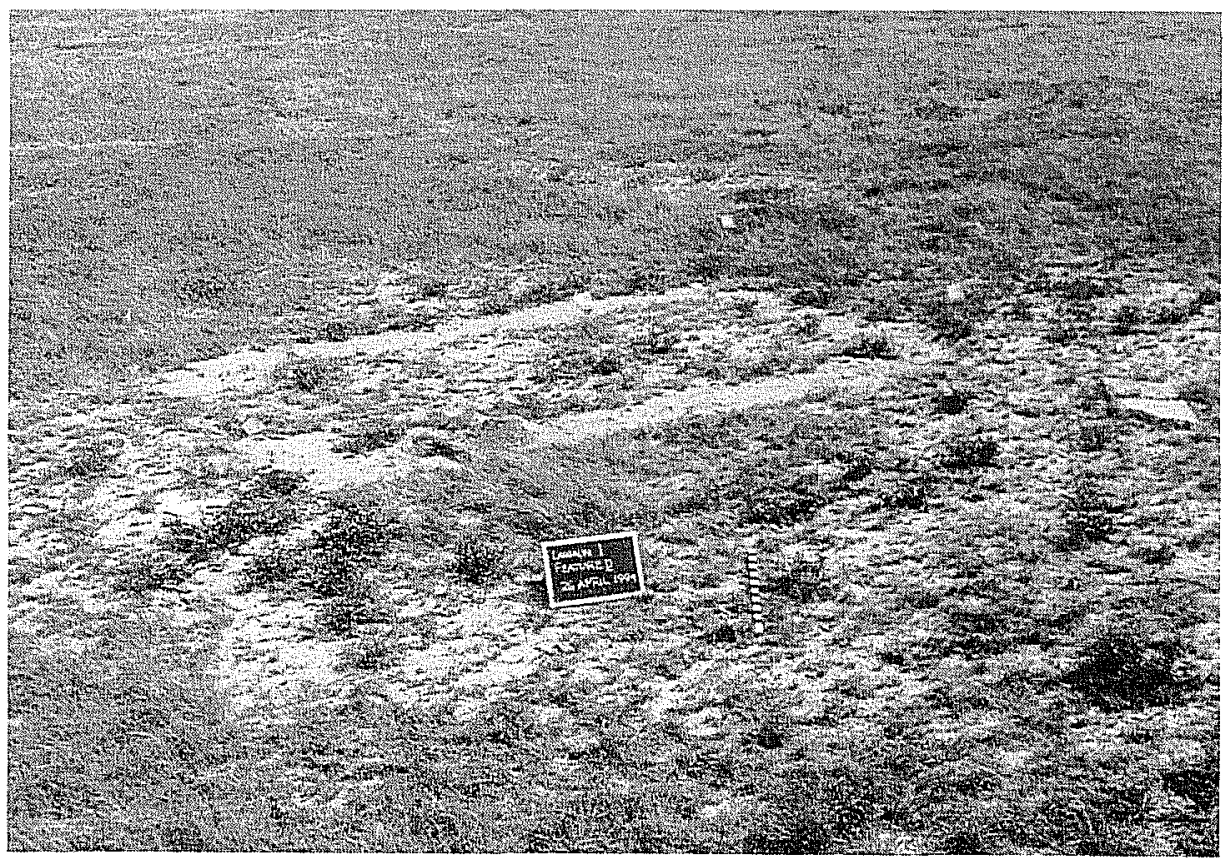

Figure 10-13. 41VV1682, Feature D, concrete foundation, looking north. 


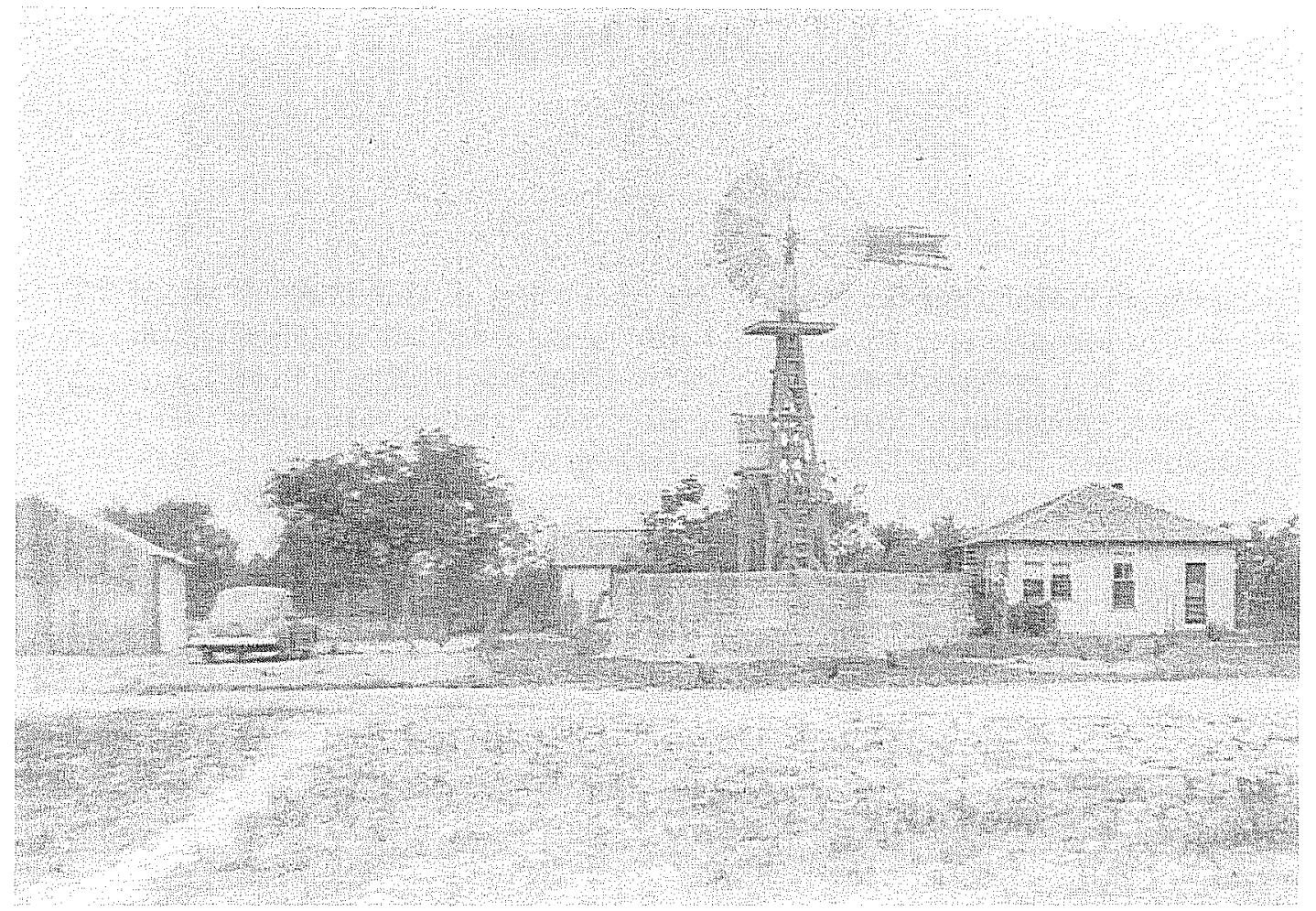

Figure 10-14. Zacatosa Ranch Headquarters, ca. 1942, looking northwest. Laughlin AFB Base Properties files.

The structures described here were built when Gilbert C. Marshall came to Del Rio from Illinois to start a sheep ranch on property leased sight-unseen from B. S. Harrison by Gilbert's father, George. Gilbert Marshall and his family lived and prospered on the ranch for 20 years, contributing to Del Rio's sheep-based economy (Figure 10-14). As mentioned above, at least one of the structures was moved from site 41VV1682, the rest being demolished and the remains removed. The obvious disturbance to the

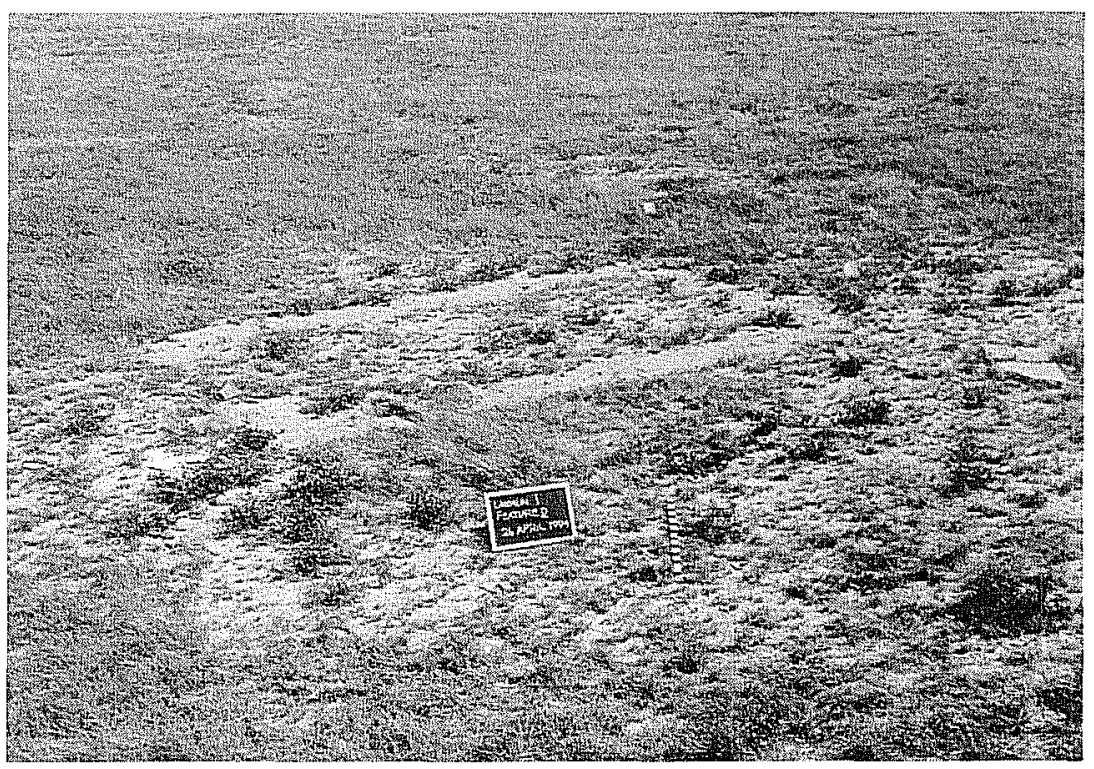

Figure 10-15. Zacatosa Ranch Headquarters, 1994, looking northwest. Feature $\mathrm{E}$ is in the foreground, Feature $\mathrm{D}$ in the background. subsurface foundations reflect an intensive scraping and leveling operation that left barely a trace of the buildings that made up the original Zacatosa Ranch headquarters used by the Marshall family (Figure 10-15). 


\section{Chapter 11. Summary and Conclusions}

\section{Cynthia L. Tennis}

During the six-week survey of Laughlin Air Force Base and Marina, one historic and eight prehistoric sites and one large site with both prehistoric and historic components were identified. Three previously recorded prehistoric sites (De Vore 1993) were revisited. All sites are within the confines of the base proper; the previously recorded site on the marina was not relocated. Surface artifact assemblage and density data were recorded from all sites, and depths of deposits were established with shovel tests. From this information, determinations have been made regarding size, content, location, and chronological placement for each site (Table 11-1). These data have been used to make inferences regarding site function, formation processes, and settlement patterns.
The sites range in size from 60 to $585,200 \mathrm{~m}^{2}$. Following site definitions established for this survey, all but one of these sites (41VV1687) is classified as a large site, covering more than $100 \mathrm{~m}^{2}$ and/or containing more than 20 artifacts or more than two cultural features. Site density within the base is 1 site per 220 acres; however, only two of the sites recorded, the historic site (41VV1682) and the highly disturbed prehistoric site (41VV1684), are located in the uplands. The remaining 11 sites are in the creek zone, along or within $100 \mathrm{~m}$ of either of the two drainage systems on the base.

Table 11-1. Site Summary

\begin{tabular}{|c|c|c|c|c|c|c|}
\hline Site \# & Drainage System & Area $\left(\mathrm{m}^{2}\right)$ & Diagnostics & $\begin{array}{l}\text { Productive } \\
\text { Shovel Tests }\end{array}$ & $\begin{array}{l}\text { Artifact } \\
\text { Depths }\end{array}$ & $\begin{array}{l}\text { Features } \\
\text { (quantity) }\end{array}$ \\
\hline VV1653 & Zorro Creek & 1,800 & none & 0 of 3 & none & FCR clusters (3) \\
\hline VV1654 & Sacatosa Creek & 585,200 & $\begin{array}{l}\text { Golondrina/Barber } \\
\text { Wilson, Gower; } \\
\text { 19th- and 20th-century } \\
\text { artifacts }\end{array}$ & 12 of 28 & $0-50 \mathrm{~cm}$ & FCR clusters (2) \\
\hline VV1655 & Sacatosa Creek & 4,500 & none & 1 of 2 & $0-20 \mathrm{~cm}$ & none \\
\hline VV1682 & Ụpland & 29,400 & $\begin{array}{l}\text { 20th-century } \\
\text { Zacatosa Ranch HQ }\end{array}$ & 0 of 5 & none & $\begin{array}{l}\text { foundation } \\
\text { remnants (15) }\end{array}$ \\
\hline VV1683 & Sacatosa Creek & 16,200 & Angostura & 5 of 9 & $0-50 \mathrm{~cm}$ & none \\
\hline VV1684 & Upland & 8,800 & none & 0 of 4 & none & none \\
\hline VV1685 & Sacatosa Creek & 72,800 & none & 3 of 19 & $0-30 \mathrm{~cm}$ & none \\
\hline VV1686 & Sacatosa Creek & 840 & none & 2 of 3 & $0-30 \mathrm{~cm}$ & hearth remnant ( 3 ) \\
\hline VV1687 & Sacatosa Creek & 60 & none & 2 of 2 & $0-20 \mathrm{~cm}$ & FCR scatter \\
\hline VV1688 & Sacatosa Creek & 12,800 & Kinney-like, Ensor & 3 of 6 & $0-30 \mathrm{~cm}$ & hearth remnant (2) \\
\hline VV1689 & Sacatosa Creek & 2,800 & Bandy/Martindale & 1 of 4 & $0-20 \mathrm{~cm}$ & $\begin{array}{l}\text { hearth remnant (1) } \\
\text { FCR clusters ( } 2)\end{array}$ \\
\hline VV1690 & Sacatosa Creek & 825 & Pedernales & 0 of 1 & none & hearth remnant (4) \\
\hline VV1691 & Sacatosa Creek & 189 & none & 1 of 2 & $0-10 \mathrm{~cm}$ & none \\
\hline
\end{tabular}




\section{HISTORIC SITES}

The historic components at 41VV1654 represent two periods. Mid- to late-nineteenth-century artifacts are associated with the southern portion of the site. The more recent historic feature in the northwest section of the site (Features D and E) are watering troughs associated with ranching activities at 41VV1682, the historic site of the 1920-1942 Zacatosa Ranch Headquarters.

\section{PREHISTORIC SITES}

Diagnostic projectile points were recovered from five of the prehistoric sites bordering Sacatosa Creek. These include Late Paleoindian and Early Archaic points from the $\mathrm{T} 2$ terrace on the west side of the creek, and Early, Middle, and Late Archaic, and Late Prehistoric points from the T1 terrace on the east side of the creek. Shovel tests from the Sacatosa Creek sites indicate that subsurface cultural deposits are present within the upper $50 \mathrm{~cm}$ on both sides of the creek. No diagnostics were recovered from 41VV1653, the one site near Zorro Creek.

\section{SITE DISTRIBUTION}

Upland hills and flats make up over 80 percent of the area surveyed Laughlin Air Force Base proper. Previous surveys in the Lower Pecos indicated that similar areas in this region played a role in prehistoric adaptive strategies, as evidenced by burned rock middens and lithic scatters recorded in upland surveys by Graham and Davis (1958), Dibble and Prewitt (1967), Turpin (1982), and Peter et al. (1990). However, with the exception of one highly disturbed and possibly secondarily deposited upland site, evidence of prehistoric land use of the upland hills and flats around Laughlin AFB is absent.

Instead, the prehistoric importance of the riverine environment is accentuated by the density of the sites identified along the portions of the floodplain and terraces of the Sacatosa Creek within Laughlin AFB. Diagnostics indicate that, with the exception of the Early Paleoindian period, this area was utilized during virtually the entire prehistoric time span, from the Late Paleoindian through the Late Prehistoric periods. Evidence of the earlier occupations remains on the high T2 terrace on the west side of the creek. Geomorphological evaluations suggests deposits of this age may have been washed away from the east side of the creek when the shallow ( $>50 \mathrm{~cm}$ thick) T1 terrace containing Middle Archaic to Late Prehistoric sites was deposited.

\section{SITE FUNCTION}

Based on analysis of lithic reduction stages and the presence/absence of cultural features, 11 of the 12 prehistoric sites have been assigned to two broad functional categories. Three of the sites (41VV1655, 41VV1683, and 41VV1685) reflect a predominance of both primary flakes and cores and tested cobbles, but no features. These sites are thought to have primarily functioned as lithic procurement sites or locations. Six of the sites, 41VV1653 and 41VV168641 VV1690, were found to contain predominately final-stage lithic reduction assemblages and remnants of hearth features; characteristics associated with residential bases, field camps, or locations. Despite the lack of features, 41VV1691 is also classified as a residential base, a field camp, or a location because of its predominately final-stage lithic assemblage. Based on the diverse lithic assemblage, burned rock features, and presence of ground stone, site $41 \mathrm{VV} 1654$, the largest of the sites recorded, is primarily classified as a residential site but probably served many prehistoric functions. Due to the disturbed nature of $41 \mathrm{VV} 1684$, no functional assessment of this site is possible.

\section{TEMPORAL LAND USE PATTERNS}

The three lithic procurement sites are located on the high T2 terrace of Sacatosa Creek. Five of the residential bases or field camp sites are found on the low T1 terrace of the Sacatosa Creek, the sixth near Zorro Creek. This pattern of functional distribution is mirrored in the temporal distribution of the diagnostic recovered. Only Late Paleoindian and Early Archaic projectile points (Angostura, Golondrina/Barber, Wilson and Gower) were recovered from the sites on the $\mathrm{T} 2$ terrace of Sacatosa Creek. With the exception of a heavily reworked Early Archaic Bandy/Martindale, projectile points recovered from the $\mathrm{T} 1$ terrace and 
floodplain were Middle Archaic to Late Prehistoric in age.

Geomorphological evidence indicates early deposits in the floodplain and $\mathrm{T} 1$ terrace may have been buried or eroded away by the later deposits, explaining the absence of Paleoindian or Early Archaic period sites there. The lack of Middle to Late Prehistoric deposits on the T2 terrace is more difficult to explain, although they may be buried in the valley fills of the bluffs and terraces.

\section{SUGGESTIONS FOR FURTHER RESEARCH}

\section{TOOL TECHNOLOGY}

We originally proposed that the prehistoric huntergather adaptation to the subtropical desert conditions of the region would be most similar to the forager settlement system proposed by Binford (1980). Such patterns of exploitation have generally be associated with an expedient tool technology. However, numerous issues have been recently identified which confound the archaeological identification of a foraging adaptation and expedient technologies. Access to raw material, reliability, and maintainability all affect the organization of stone tool technology, as does the settlement system. Given that archaeological methods are not yet able to break apart this complex set of interacting variables and that a small number of artifacts was recovered, further evaluation of these issues is difficult at this time.

\section{UPLAND EXPLOITATION}

We also originally suggested that the upland regions would be characterized by evidence of exploitation of succulent plants which have been demonstrated, on the basis of data from rockshelters, to be a critical aspect of the diet throughout most of the prehistoric occupation of the region. However, there was little evidence of exploitation of the upland portions of the base. The archaeological sites identified suggest that use of the regions distant from the archaeologically rich canyonlands, for purposes other than succulent exploitation, formed important aspects of the prehistory of the area.

Further archaeological investigations at these temporally distinct sites within the drainage systems of Laughlin Air Force Base are needed. Such studies would augment this preliminary investigation of prehistoric adaptation away from the major canyons and rivers of the Lower Pecos, an aspect of the region's archaeology about which we know little. 


\title{
Chapter 12. Site Assessments and Recommendations
}

\author{
Cynthia L. Tennis, Anna Jean Taylor, and Robert J. Hard
}

\section{NATIONAL REGISTER SIGNIFICANCE CRITERIA}

The National Register of Historic Places (NRHP) was created by the National Historic Preservation Act of 1966. The latter widened the federal government's purview over historic resources to include those of state and local significance. This made eligible not only national historic landmarks, but also a much broader spectrum of historic culture. Eligibility criteria, as enumerated in the 36 CFR 60 implementing federal regulations, consist of the following.

The quality of significance in American history, architecture, archaeology, and culture that is present in districts, sites, buildings, structures, and objects that possess integrity of location, design, setting, materials, workmanship, feeling, and association, and:

(a) that are associated with events that have made a significant contribution to the broad patterns of our history; or,

(b) that are associated with the lives of persons significant in our past; or,

(c) that embody the distinctive characteristics of a type, period, or method of construction, or that represent the work of a master, or that possess high artistic values, or that represent a significant and distinguishable entity whose components may lack individual distinction; or,

(d) that have yielded, or may be likely to yield, information important in prehistory or history.

Therefore, in order to qualify for National Register eligibility, a property must meet two separate types of requirements. It must exhibit integrity of location, design, materials, etc., and it must meet one or more of the four additional criteria. The National Historic Preservation Act makes clear that a site need not be of national significance to be considered eligible for nomination; sites of state, regional, and local importance may also be listed. A site need not be included on the NRHP to be afforded protection under the law, but must simply meet the requirements of eligibility.

The wording of the criteria for eligibility clearly indicates that the regulations were initially written with historic buildings in mind; however, prehistoric and historic archaeological sites are generally evaluated against Criteria $D$, that is, could they potentially yield information important in prehistory or history. In addition, the NRHP was designed to be selective; significance must be demonstrated on a site-specific or district basis. Sites which share historic contexts and property type may be grouped for nomination as a multiple property listing.

\section{NATIONAL REGISTER RECOMMENDATIONS}

The assessments of significance of the cultural resources within the Laughlin AFB project area are based upon Criterion D of the 36 CFR 60 eligibility criteria. Location, chronological association, cultural features and depth of cultural deposit of each site recorded on Laughlin Air Force Base is shown in Table 12-1. Of the 13 archaeological sites recorded on Laughlin Air Force Base, the 10 sites that cluster along the drainage of the Sacatosa Creek (41VV1654, 41VV1655, 41VV1683, and 41VV1685-1691) as well as 41VV1653 near Zorro Creek are considered significant, so we recommend they be considered eligible for multiple properties nomination to the NRHP.

These sites form a cluster of open sites within the two drainage systems on the base that span the Paleoindian through Late Prehistoric time periods and have the potential to offer data on changing patterns of mobility, subsistence, and land-use in the context 
Table 12-1. Initial Assessments for NRHP Eligibility

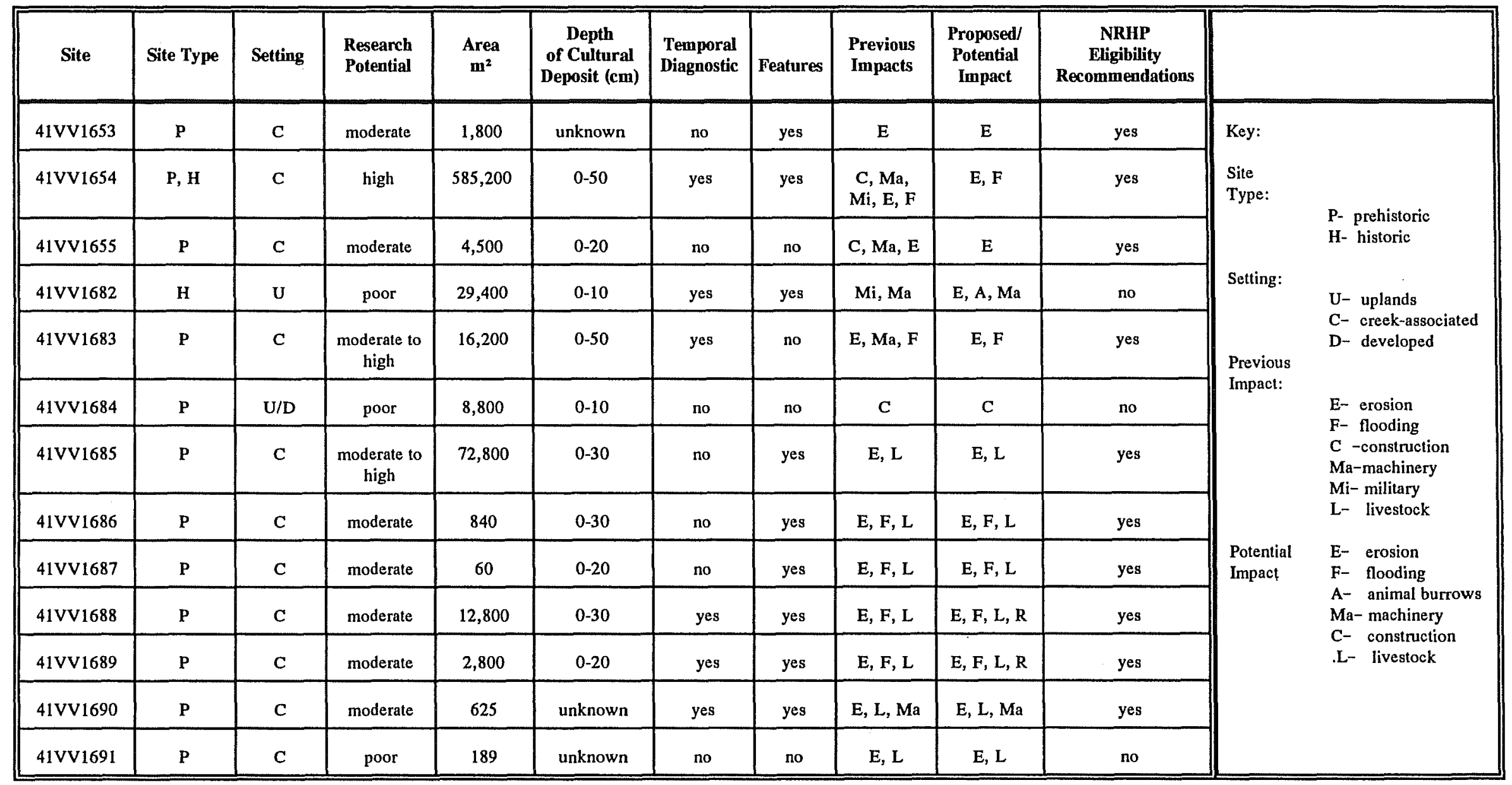


of "collector-forager" adaptations in this region. Subsurface cultural material was recovered in shovel tests from nine of these sites along the Sacatosa, indicating deposits extend to depths of $10-50 \mathrm{~cm}$ below the surface. Diagnostic projectile pointsincluding Angostura, Golondrina/Barber, Wilson, Gower, Bandy/Martindale, Kinney-like, and Pedernales-like-representing Late Paleoindian through Late Prehistoric occupations were recovered from five of these sites. The diagnostics recovered from five of the sites along the Sacatosa Creek drainage identify two of the sites on the T2 terrace of the creek as Late Paleoindian to Early Archaic sites, while diagnostics from the sites on the $\mathrm{T} 1$ terrace and floodplain are virtually all from the Middle Archaic through Late Prehistoric time periods. Limited testing of the single Zorro Creek site produced no diagnostics or subsurface material, although three features are present.

These creek-associated sites present a unique set of cultural resources indicating extensive and/or intensive human usage of natural resources along Sacatosa Creek. The results of this study indicate these sites retain data relevant to the understanding of the prehistory of both the area and the region.

\section{MITIGATION OPTIONS}

Mitigative measures consist of several forms of management options which have the effect of eliminating or decreasing the harmful impact upon sites. The choice of mitigation options is dictated by three factors: the significance of the site, the physical nature of the site, and the nature of a proposed impact. As a rule the most desirable options are those which ensure the continued existence of a resource, generally avoidance or protection. These options are preferred from a conservation standpoint, and are generally the most cost effective. If these options are impracticable, impacts must be lessened by data retrieval. The exact nature of data retrieval depends largely upon the nature and physical composition of the site and the information it contains, as well as the severity of the proposed impact. Sites which fail to meet eligibility criteria for the NRHP are not afforded protection under the law.

Avoidance or protection of the significant sites listed in Table $12-1$ is recommended. However, should avoidance or protection of some or all of these sites be deemed impractical, a two-phase investigation would be appropriate: a testing phase to develop an efficient and effective mitigation plan, followed by the comprehensive data-recovery phase. Each subsequent phase builds upon the results of the previous phase and would be designed to meet the particular cultural resource management needs of Laughlin AFB.

The testing phase to obtain additional data to develop the data recovery plan would consist of detailed instrument mapping, controlled surface collections, and test excavations (Table 12-2). Instrument mapping provides a substantially greater level of precision than the compass-and-pace maps drawn during the survey. This precision is critical for evaluating the integrity of the surface deposits, to identify meaningful functional or temporal artifact and feature clusters, and to maintain the provenience of the archaeological materials. Controlled surface collections provide representative samples of the lithic materials which can then be evaluated for information such as the identification of raw material sources and technological data to pursue issues related to the changing organization of the lithic technology.

Existing features would be at least partially excavated to determine their potential for yielding dating and functional information. Subsurface testing would be conducted to determine the horizontal extent of the buried deposits and to confirm our initial findings of their depth, to search for buried features, and to evaluate the geomorphological history of the site. These tests would also indicate if the sites are stratified and allow further evaluation of the integrity of the deposits. Subsurface tests would be conducted by a mix of shovel tests, $1-\mathrm{x}-1-\mathrm{m}$ test units, backhoe trenches, and possibly horizontal exposures using a Gradall machine.

The results of this testing program would be evaluated to design further archaeological work necessary during the mitigation phase. This determination would be affected by the level of site damage anticipated and would be made in consultation with the State Historic Preservation Officer. 
Table 12-2. Archaeological Site Testing Methods Recommended for Data Retrieval Design

\begin{tabular}{|c|c|c|c|c||}
\hline Site & Mapping & $\begin{array}{c}\text { Controlled } \\
\text { Surface } \\
\text { Collection }\end{array}$ & $\begin{array}{c}\text { Controlled Test } \\
\text { Units } \\
\text { (1- } \text { - 1-m) }\end{array}$ & $\begin{array}{c}\text { Machine-dug } \\
\text { Trenches }\end{array}$ \\
\hline 41 VV1653 & $\mathrm{X}$ & $\mathrm{X}$ & $\mathrm{X}$ & $\mathrm{X}$ \\
\hline $41 \mathrm{VV1654}$ & $\mathrm{X}$ & $\mathrm{X}$ & $\mathrm{X}$ & $\mathrm{X}$ \\
\hline $41 \mathrm{VV1655}$ & $\mathrm{X}$ & $\mathrm{X}$ & $\mathrm{X}$ & $\mathrm{X}$ \\
\hline $41 \mathrm{VV1683}$ & $\mathrm{X}$ & $\mathrm{X}$ & $\mathrm{X}$ & $\mathrm{X}$ \\
\hline $41 \mathrm{VV1685}$ & $\mathrm{X}$ & $\mathrm{X}$ & $\mathrm{X}$ & $\mathrm{X}$ \\
\hline $41 \mathrm{VV1686}$ & $\mathrm{X}$ & $\mathrm{X}$ & $\mathrm{X}$ & $\mathrm{X}$ \\
\hline $41 \mathrm{VV1687}$ & $\mathrm{X}$ & $\mathrm{X}$ & $\mathrm{X}$ & $\mathrm{X}$ \\
\hline $41 \mathrm{VV1688}$ & $\mathrm{X}$ & $\mathrm{X}$ & $\mathrm{X}$ & $\mathrm{X}$ \\
\hline $41 \mathrm{VV1689}$ & $\mathrm{X}$ & $\mathrm{X}$ & $\mathrm{X}$ & $\mathrm{X}$ \\
\hline $41 \mathrm{VV1690}$ & $\mathrm{X}$ & $\mathrm{X}$ & & \\
\hline
\end{tabular}

\section{SITES NOT RECOMMENDED FOR FURTHER INVESTIGATION}

No further investigations are recommended for sites $41 \mathrm{VV} 1682$ or $41 \mathrm{VV} 1684$. The latter is not recommended as site integrity is questionable due to the disturbed nature of the subsurface deposits. The artifacts may have been brought in with the fill soil or, minimally, the site appears to have been destroyed by construction.

A more detailed explanation for not recommending further investigations at historic site 41 VV1682 is necessary. Site 41 VV1682 has been identified as the historic Zacatosa Ranch Headquarters. It served as a sheep ranching operation that existed prior to the 1942 acquisition of the property by the U.S. government as a training facility. Archival records and informants have documented the nature and form of these structures.
While the story of sheep ranching within the western portion of the state shortly after the turn of the century is a highly significant topic which is critical to understanding the history of the region, further investigation of the highly disturbed remaining traces of the ranch headquarters would not contribute enough additional information to justify further archaeological investigation. The important story of the early economic history could be documented through further archival and oral history investigations. A display of historic photographs and/or artifacts for the base might be considered to serve as a opportunity for public relations and information. 


\section{REFERENCES CITED}

Abbott, J. T.

1991 Appendix II: Geomorphology and Soils Characteristics at Site 41VV1251. In Archaeological Testing for a Proposed Landfill Expansion (Phase II), City of Del Rio, Val Verde County, Texas, pp. 16-27, edited by J. D. Eaton, R. W. Burkett, H. G. Uecker, and J. T. Abbott. Archaeological Survey Report, No. 197. Center for Archaeological Research, The University of Texas at San Antonio.

Adams, E. K.

1922 Del Rio's Railroad Facilities, Present and Future. Sheep and Goat Raisers' Magazine 2(7):22.

Adams, R. E. W. (assembler)

1975 Archaeology and Ethnohistory of the Gateway Area, Middle Rio Grande of Texas. Report of the 1975 Investigations. Mamuscript on file, Center for Archaeological Research, The University of Texas at San Antonio.

1976 The Archaeology and Ethnohistory of the Gateway Area, Middle Rio Grande of Texas. Report of the 1976 Investigations. Manuscript on file, Center for Archaeological Research, The University of Texas at San Antonio.

Alexander, R. K.

1970 Archeological Investigations at Parida Cave, Val Verde County, Texas. Papers of the Texas Archaeological Salvage Project 19. The University of Texas at Austin.

1974 The Archaeology of Conejo Shelter: A Study of Cultural Stability at an Archaic Rockshelter Site in Southwestern Texas. Ph.D. dissertation, Department of Anthropology, The University of Texas at Austin.

Almaraz, F. D., Jr.

1979 Crossroads of Empire: The Church and State in the Rio Grande Frontier of Coahuila and Texas, 1700-1821. Archaeology and History of the San Juan Bautista Mission Area, Coahuila and Texas, Report No. 1. Center for Archaeological Research, The University of Texas at San Antonio.

1980 Inventory of the Rio Grande Mission: 1772 San Juan Bautista and San Bernardo, translated and edited by F. D. Almaraz, Jr. Archaeology and History of the San Juan Bautista Mission Area, Coahuila and Texas, Report No. 2. Center for Archaeological Research, The University of Texas at San Antonio.

Ammerman, A. J., and M. W. Feldman

1974 On the "Making" of an Assemblage of Stone Tools. American Antiquity 39:610-616.

Bailey, H. P.

1960 A Method of Determining the Warmth and Temperateness of Climate. Geografiska Annaler 43(1):1-16.

Bamforth, D. B.

1986 Technological Efficiency and Tool Curation. American Antiquity 51:38-50.

Bannon, J. F.

1963 The Spanish Borderlands Frontier, 1513-1821. University of New Mexico Press, Albuquerque.

Barnes, V. E.

1977 Geologic Atlas of Texas, Del Rio Sheet. Bureau of Economic Geology, The University of Texas at Austin. 
Bement, L. C.

1989 Lower Pecos Canyonlands. In From the Gulf Coast to the Rio Grande: Human Adaptation in the Central, South, and Lower Pecos Texas, edited by T. R. Hester, S. L. Black, D. G. Steele, B. W. Olive, A. A. Fox, K. J. Reinhard, and L. C. Bement, pp. 63-76. Research Series No. 33. Arkansas Archeological Survey, Fayetteville.

Benfer, R. A., and T. W. McKern

1968 Analysis of Human Skeletal Remains from Coontail Spin. Bulletin of the Texas Archeological Society 38:66-75.

Binford, L. R.

1973 Interassemblage Variability: The Mousterian and the 'Functional Argument'. In The Explanation of Cultural Change: Models in Prehistory, edited by C. Renfrew, pp 227-254. Duckworth, London.

1977 Forty-seven Trips: A Case Study in the Character of Archaeological Formation Processes. In Stone Tools as Cultural Markers: Change, Evolution and Complexity, edited by R. V. S. Wright, pp.24-36. Australian Institute of Aboriginal Studies, Canberra.

1979 Organization and Formation Processes: Looking at Curated Technologies. Journal of Anthropological Research 35:255-273.

1980 Willow Smoke and Dogs' Tails: Hunter-Gatherer Settlement Systems and Archaeological Site Formation. American Antiquity 45:4-20.

Black, S. L.

1989 Environmental Setting. In From the Gulf Coast to the Rio Grande: Human Adaptation in the Central, South, and Lower Pecos Texas, edited by T. R. Hester, S. L. Black, D. G. Steele, B. W. Olive, A. A. Fox, K. J. Reinhard, and L. C. Bement, pp. 5-17. Research Series No. 33. Arkansas Archeological Survey, Fayetteville.

Blair, W. F.

1950 The Biotic Provinces of Texas. Texas Journal of Science 2(1):93-117.

Bleed, P.

1986 The Optimal Design of Hunting Weapons: Maintainability or Reliability. American Antiquity 51:737-747.

Blum, M. R., and S. Valastro, Jr.

1989 Response of the Pedernales River of Central Texas to late Holocene Climatic Change. Annals of the Association of American Geographers 79:435-456.

Bolton, H. E.

1959 Spanish Exploration in the Southwest, 1542-1706. Barnes and Nobel, New York.

Bousman, C. B.

1993 Hunter-Gatherer Adaptations, Economic Risk and Tool Design. Lithic Technology 18:59-86.

Bowden, J. J.

1986 The Exodus of Federal Forces from Texas: 1861. Eakin, Austin.

Briggs, A. K.

1974 The Archeology of 1882 Labor Camps on the Southern Pacific Railroad, Val Verde County, Texas. Master's thesis, The University of Texas at Austin. 
Brown, $\mathrm{H}$.

1976 A Link With the Past. La Hacienda, pp. 427-433. Whitehead Memorial Museum and the Val Verde Historical Commission, Del Rio.

Brown, K. M.

1991 Prehistoric Economics at Baker Cave: A Plan for Research. In Papers on Lower Pecos Prehistory, edited by S. A. Turpin, pp. 87-140. Studies in Archeology 8. Texas Archeological Research Laboratory, The University of Texas at Austin.

Bryant, V. M., Jr.

1974 Prehistoric Diet in Southwest Texas: The Coprolite Evidence. American Antiquity 39(3):407-420.

1986 Prehistoric Diet: A Case for Coprolite Analysis. In Ancient Texans: Rock Art and Lifeways along the Lower Pecos, edited by H. J. Shafer, pp. 132-135. Texas Monthly, Austin.

Bryant, V. M., Jr., and R. G. Holloway

1985 A Late-Quaternary Paleoenvironmental Record of Texas: An Overview of the Pollen Evidence. In Pollen Records of Late Quaternary North American Sediments, edited by V. M. Bryant and R. G. Holloway, pp. 39-70. American Association of Stratigraphic Palynologists Foundation, Dallas.

Bryant, V. M., Jr., and H. J. Shafer

1977 The Late Quaternary Paleoenvironment of Texas: A Model for the Archaeologists. Bulletin of the Texas Archeological Society 48:1-25.

Campbell, T. N.

1972 Systematized Ethnohistory and Prehistoric Culture Sequences in Texas. Bulletin of the Texas Archaeological Society 43:1-11.

1979 Ethnohistoric Notes on Indian Groups Associated with Three Spanish Mission at Guerrero, Coahuila. Archaeology and History of the San Juan Bautista Mission Area, Coahuila and Texas, Report No. 3. Center for Archaeological Research, The University of Texas at San Antonio.

1991 Coahuiltecans and their Neighbors. In Ethnology of the Texas Indians, edited by T. R. Hester, pp. 109-126. Spanish Borderlands Sourcebooks 7. Garland, New York.

Campbell, T. N., and T. J. Campbell

1981 Historic Indians of the Choke Canyon Reservoir Surrounding Area, Southern Texas. Choke Canyon Series, No. 1. Center for Archaeological Research, The University of Texas at San Antonio.

1988 Cabeza de Vaca Among the Indians of Southern Texas. In The Indians of Southern Texas and Northeastern Mexico, Selected Writings of Thomas Nolan Campbell. edited by T. N. Campbell, pp. 7-38. Texas Archeological Research Laboratory, The University of Texas at Austin.

Carlson, $\mathbf{P}$.

1982 Texas Woolybacks. Texas A\&M University Press, College Station.

Chadderdon, M. F.

1981 Baker Cave, Val Verde County, Texas. The 1976 Excavations. Master's thesis, The University of Texas at San Antonio.

1983 Baker Cave, Val Verde County, Texas: The 1976 Excavations. Special Report, No. 13. Center for Archaeological Research, The University of Texas at San Antonio.

Clark, C. T., R. H. Ryan, J. H. Jones, and C. A. Pieper

1964 Del Rio: Border of Texas Industrialization. Area Economic Survey No. 21. Bureau of Business Research, The University of Texas at Austin. 
Collins, M. B.

1969 Text Excavations at Amistad International Reservoir Fall, 1967. Papers of the Texas Archeological Salvage Project 16. The University of Texas at Austin.

Cronon, W.

1991 Nature's Metropolis. W. W. Norton, New York.

Daniels, E. C.

1922 Del Rio's Water Supply and Irrigation System. Sheep and Goat Raisers'Magazine 2(7):51-53.

Davenport, J. W.

1936a Field Notes of March 1935 Survey of Eagle Cave. Manuscript on file, Witte Museum. San Antonio.

1936b Field Notes of September 1935 Survey of Eagle Cave. Manuscript on file, Witte Museum. San Antonio.

1937 Field Notes of 1936 Excavation of Eagle Cave. Manuscript on file, Witte Museum, San Antonio.

Del Rio, M.

1956 A Preliminary Report on the Mortuary Cave of Candelaria, Coahuila, Mexico. Bulletin of the Texas Archaeological Society 24:208-252.

Dering, J. P.

1977 Plant Macrofossil Study: A Progress Report. In Archaeological and Botanical Studies at Hinds Cave, Val Verde County, Texas, edited by H. J. Shafer and V. M. Bryant, Jr., pp. 84-102. Texas A\&M University Anthropology Laboratory Special Series 1. Texas A\&M Research Foundation, College Station.

1979 Pollen and Plant Macrofossil Vegetation Record Recovered from Hinds Cave, Val Verde County, Texas. Master's thesis, Department of Botany, Texas A\&M University.

Dering, J. P., and H. J. Shafer

1976 Analysis of Matrix Samples from a Crockett County Shelter. Bulletin of the Texas Archeological Society 47:209-229.

de Vaca, C.

1984[1527] Cabeza de Vaca's Adventures in the Unknown Interior of America. Translated and edited by C. Covey. University of New Mexico Press, Albuquerque.

De Vore, S. L.

1993 Cultural Resource Assessment of Lackland Air Force Base and Training Annex, Bexar County, Texas. Interagency Archeological Services, National Park Service, Denver. Submitted to Headquarters, Air Education and Training Command, Randolph Air Force Base, Texas.

Dial, S. W.

1992 An Analysis of Ceramic Artifacts from the Alamo Lunette Trench (41BX6), San Antonio, Texas. In Archaeological Investigations in Alamo Plaza, San Antonio, Bexar County, Texas, edited by A. A. Fox, pp. 29-46. Archaeological Survey Report, No. 205. Center for Archaeological Research, The University of Texas at San Antonio.

Dibble, D. S.

1975 Archeological Investigations at Bonfire Shelter, Texas. Ph.D. Dissertation, Department of Anthropology, Washington State University, Pullman.

Dibble, D. S., and D. Lorrain

1968 Bonfire Shelter: a Stratified Bison Kill Site, Val Verde County, Texas. Miscellaneous Papers 1. Texas Memorial Museum, Austin. 
Dibble, D. S., and E. R. Prewitt

1967 Survey and Test Excavations at Amistad Reservoir, 1964-1965. Survey Report 3. Texas Archeological Salvage Project, Austin.

Dice, L. R.

1943 The Biotic Provinces of North America. University of Michigan Press, Ann Arbor.

Douglas, C. L.

1970 Analysis of the Faunal Remains. In Excavations at Baker Cave, Val Verde County, Texas. Bulletin of the Texas Memorial Museum 16. The University of Texas at Austin.

Doughty, R.

1986 From Wilderness to Garden: Conquering the Texas Landscape. In Texas Myths, edited by R. F. O’Conner, pp 105-121. Texas A\&M University Press, College Station.

Edwards, A. G.

1922 Del Rio Real Estate Values. Sheep and Goat Raisers' Magazine, 2(7):43-44.

Everitt, J. H., and D. L. Drawe

1993 Trees, Shrubs \& Cacti of South Texas. Texas Tech University Press, Lubbock.

Epstein, J. F.

1963 Centipede and Damp Caves: Excavations in Val Verde County Texas, 1958. Bulletin of the Texas Archeological Society 33:1-129.

Ewers, J. C.

1973 The Influence of Epidemics on the Indian Populations and Cultures of Texas. Plains Anthropologist 18(6):104-115.

Faulk, O. B.

1969 The Comanche Invasion of Texas, 1743-1836. Great Plains Journal 9(1):10-50.

Fehrenbach, T. R.

1986 Texas Mythologies: Now and Forever. In Texas Myths, edited by R. F. O'Conner, pp. 204-226. Texas A\&M University Press, College Station.

Flyr, D.

1966 The Contemporary Vegetation of the Amistad Reservoir Area. In A Preliminary Study of the Paleoecology of the Amistad Reservoir Area, assembled by D. A. Story and V. M. Bryant, Jr., pp. 33-60. Report submitted to the National Science Foundation.

Forman, J. A.

1922 The Clubs of Del Rio. Del Rio. Sheep and Goat Raisers'Magazine 2(7):26.

Fox, A. A.

1989 Historic Anglo-European Exploration and Colonization. In From the Gulf Coast to the Rio Grande: Human Adaptation in the Central, South, and Lower Pecos Texas, edited by T. R. Hester, S. L. Black, D. G. Steele, B. W. Olive, A. A. Fox, K. J. Reinhard, and L. C. Bement, pp. 85-92. Research Series No. 33. Arkansas Archaeological Survey, Fayetteville. 
Fox, A. A., and I. W. Cox

1983 Archaeological and Historical Investigations at the Valenzuela Ranch, Dimmit County, Texas. Archaeological Survey Report, No. 126, Center for Archaeological Research, The University of Texas at San Antonio.

Frizzell, D. L.

1954 Handbook of Cretaceous Foraminifera of Texas. Report of Investigation No. 22. Bureau of Economic Geology, University of Texas at Austin.

Gates, W. C. Jr., and D. E. Ormerod

1982 The East Liverpool Pottery District: Identification of Manufacturers and Marks. Historical Archaeology 16:1-2.

Gile, L. H., F. F. Peterson, and R. B. Grossman

1966 Morphological and Genetic Sequences of Carbonate Accumulation in Desert Soils. Soil Science 101:347-360.

Gillis, Mrs. W.

1922 Literary and Artistic Development in Del Rio. Sheep and Goat Raisers' Magazine. February.

Glassman, D. M.

1985 Analysis of Skeletal Remains from Southwest Texas. Manuscript on file, Witte Museum. San Antonio.

Godden, G. A.

1963 British Pottery and Porcelain, 1780-1850. A. S. Barnes, Cranbury, New Jersey.

Goetzmann, W. H.

1986 Keep the White Lights Shining. Texas Myths, edited by R. F. O'Conner, pp. 70-80. Texas A\&M University Press, College Station.

Golden, M. L., W. J. Gabriel, and J. W. Stevens

1982 Soil Survey of Val Verde County, Texas. U.S. Department of Agriculture. Soil Conservation Service, Washington, D.C.

Gould, F. C., and P. N. Pando

1991 Claiming their Land: Women Homesteaders in Texas. Southwestern Studies \#93. University of Texas Press, El Paso.

Graham, J.

1978 Folk Housing in South and West Texas. In Proceedings, An Exploration of a Common Legacy: A Conference in Border Architecture, directed by E. Heck, pp. 38-45. Texas Historical Commission, Austin.

Graham, J. A. and W. Davis

1958 Appraisal of the Archeological Resources of Diablo Reservoir, Val Verde County, Texas. Report to the National Park Service. Archeological Salvage Program, Austin.

Green, W. D.

1922 Del Rio Club Life. Sheep and Goat Raisers' Magazine 2(7):27-28.

Greer, G. H., and H. Black

1971 The Meyer Family: Master Potters of Texas. Trinity University Press, San Antonio. 
Greer, J. W.

1966 Results of Archaeological Excavations at the Castle Canyon Site, Val Verde County, Texas. Southwesterm Lore 32(1):10-18.

1968 The Cammack Site: A Neo-American Pit-Oven Ring Midden Site in Val Verde County, Texas. Master's thesis, The University of Texas at Austin.

Greer, J. W., and R. A. Benfer

1963 Langtry Creek Burial Cave, Val Verde County, Texas. Bulletin of the Texas Archaeological Society 33:229-251.

Grieder, T.

1966 Periods in Pecos Style Pictographs. American Antiquity 31:710-720.

Hall, F. S.

1986 Adventures of an Early-Day Sheepman. Ranch Magazine 67(9):25-27, 31-32, 45-46.

Hammond, G. P., and A. Rey

1967 Expedition into New Mexico Made by Antonio de Espejo 1582-1583. Arno, New York.

Hard, R. J., K. J. Gross, B. A. Meissner, E. C. Newcomb, G. R. Raymond, M. Renner, A. J. Taylor, and C. L. Tennis

1994 Field Summary of an Archaeological Survey of Laughlin Air Force Base, Del Rio Texas. Report submitted to the Rocky Mountain Region, National Park Service, Department of the Interior, Denver. Center for Archaeological Research, The University of Texas at San Antonio.

Hardesty, D. L.

1985 Evolution on the Industrial Frontier. In The Archaeology of Frontiers and Boundaries, edited by S. W. Green and S. M. Perlman, pp. 213-226. Academic, Orlando.

Hatch, S. L., and J. Pluhar

1993 Texas Range Plants. Texas A\&M University Press, College Station.

Havins, T. R.

1924 Sheepmen-Cattlemen Antagonisms on the Texas Frontier. West Texas Historical Association Year Book, Del Rio.

Herring, J. B.

1986 Cultural and Economic Resilience Among the Kickapoo Indians of the Southwest. Great Plains Quarterly 6(4):263-275.

Hester, T. R.

1979 Early Populations in Prehistoric Texas. Archaeology 32(6):26-33.

1983 Late Paleo-Indian Occupations at Baker Cave, Southwestern Texas. Bulletin of the Texas Archeological Society 53:101-119.

1986 Baker Cave: A Rich Archaeological Record. In Ancient Texas: Rock Art and Lifeways along the Lower Pecos, edited by H. J. Shafer, pp. 84-87. Texas Monthly, Austin.

1989a Introduction. In From the Gulf Coast to the Rio Grande: Human Adaptation in the Central, South, and Lower Pecos Texas, by T. R. Hester, S. L. Black, D. G. Steele, B. W. Olive, A. A. Fox, K. J. Reinhard, and L. C. Bement, pp 1-4. Research Series No. 33. Arkansas Archeological Survey, Fayetteville. 
1989b An Archeological Synthesis. In From the Gulf Coast to the Rio Grande: Human Adaptation in the Central, South, and Lower Pecos Texas, by T. R. Hester, S. L. Black, D. G. Steele, B. W. Olive, A. A. Fox, K. J. Reinhard, and L. C. Bement, pp 115-128. Research Series No. 33. Arkansas Archeological Survey, Fayetteville.

1989c Historic Native American Populations. In From the Gulf Coast to the Rio Grande: Human Adaptation in the Central, South, and Lower Pecos Texas, by T. R. Hester, S. L. Black, D. G. Steele, B. W. Olive, A. A. Fox, K. J. Reinhard, and L. C. Bement, pp 77-84. Research Series No. 33. Arkansas Archeological Survey, Fayetteville.

Hester, T. R., S. L. Black, D. G. Steele, B. W. Olive, A. A. Fox, K. J. Reinhard, and L. C. Bement

1989 From the Gulf Coast to the Rio Grande: Human Adaptation in the Central, South, and Lower Pecos Texas. Research Series No. 33. Arkansas Archaeological Survey, Fayetteville.

Holliday, V. T.

1990 Pedology in Archaeology. In Archaeological Geology of North America, vol. 4, edited by N. P. Lasca and J. Donahue, pp. 525-54. Geological Society of America, Boulder.

Hollon, W. E.

1961 The Southwest: Old and New. Alfred A. Knopf, New York.

Howe, H. V. and L. Laurencich

1958 Introduction to the Study of Cretaceous Ostracoda. Louisiana State University Press, Baton Rouge.

Huebner, J. A.

1991 Cactus for Dinner, Again! An Isotope Analysis of Late Archaic Diet in the Lower Pecos Region of Texas. In Papers on Lower Pecos Prehistory edited by S. A. Turpin, pp. 175-190. Studies in Archeology 8, Texas Archeological Research Laboratory, The University of Texas at Austin.

Inglis, J. M.

1964 A History of Vegetation on the Rio Grande Plain. Texas Parks and Wildlife Department Bulletin No. 45, Austin.

Irving, R. S.

1966 A Preliminary Analysis of Plant Remains from Six Amistad Reservoir Sites. In A Preliminary Study of the Paleoecology of the Amistad Reservoir, assembled by D.A. Story and V. M. Bryant, Jr., pp. 61-90. Report submitted to the National Science Foundation.

John, E. A. H.

1975 Storms Brewed in Other Men's Worlds: The Confrontation of Indians, Spanish, and French in the Southwest, 1540-1795. Texas A\&M University Press, College Station.

Johnson, L., Jr.

1963 Pollen Analysis of Two Archeological Sites at Amistad Reservoir, Texas. Texas Journal of Science 15:225-230.

1964 The Devil's Mouth Site: A Stratified Campsite at Amistad Reservoir Val Verde County, Texas. Archaeology Series 6. Department of Anthropology, The University of Texas at Austin.

Jones, Mrs. J. M.

1927 Efficient Range Utilization: Cattle, Sheep and Goats in Combination Improve Pastures. The Cattleman 13(10):95-99, 101, 110. 
Jordan, T. G.

1974 Antecedents of the Long-Lot in Texas. Annals of the Association of American Geographer 64(1):70-86.

Kelly, R. L.

1983 Hunter-Gatherer Mobility Strategies. Journal of Anthropological Research 39:277-306.

1988 The Three Sides of a Biface. American Antiquity 53:717-734.

Kendall, G. W.

1959 Letters From a Texas Sheep Ranch: Written in the Years 1860 and 1867 by George Wilkins Kendall to Henry Stephens Randall, edited by H. J. Brown. University of Illinois Press, Urbana.

Kintigh, K. W.

1984 Measuring Archaeological Diversity by Comparison with Simulated Assemblages. American Antiquity 49(1):44-54.

Kirkland, F.

1937 A Study of Indian Pictures in Texas. Bulletin of the Texas Archeological and Paleontological Society 9:89-119.

1938 A Description of Texas Pictographs. Bulletin of the Texas Archeological and Paleontological Society 10:11-39.

1942 Historic Material from Fielder Canyon Cave. Bulletin of the Texas Archeological and Paleontological Society 1:11-40.

Kirkland, F., and W. W. Newcomb, Jr.

1967 The Rock Art of Texas Indians. University of Texas Press, Austin.

Knapf, K., D. E. Peter, and S. N. Allday

1994 An Overview of the Pre-Installation History of the Laughlin Air Force Base Area, The Lower Pecos River Region, Val Verde County, Texas. Geo-Marine, Plano, Texas.

Kochel, R. C.

1982 Quaternary Geomorphology of Seminole Canyon Historical Park, Val Verde County, Texas. In Seminole Canyon: The Art and Archeology, edited by S. A. Turpin, pp. 227-276. Research Report 83. Texas Archeological Survey, The University of Texas at Austin.

Kupper, W.

1921 Folk Characters of the Sheep Industry. Cattleman 21:89-103.

1945 The Golden Hoof: The Story of the Sheep of the Southwest. Alfred A. Knopf, New York.

1951 Texas Sheepman: The Reminiscences of Robert Maudslay. University of Texas Press, Austin.

Labadie, J. H.

1986 An Archaeological Survey of a Proposed Water Main in Val Verde County, Texas. Archaeological Survey Report, No. 158, Center for Archaeological Research, The University of Texas at San Antonio.

1994 Amistad National Recreation Area: Cultural Resources Study. National Park Service, Santa Fe.

la Cross, J.

1922 Del Rio Home of the Sheep and Goat Raiser's Ass'n. of Texas. Sheep and Goat Raisers' Magazine 2(7):44-46.

Lasher, C.

1989 Fossils on Laughlin Air Force Base, Texas. Manuscript on file, base library. Laughlin Air Force Base, Texas. 
Laufenburg, C. A.

1922 Del Rio as a Wholesale Distributing Center. Sheep and Goat Raisers' Magazine 2(7):49-50.

Lehmann, V. W.

1969 Forgotten Legions: Sheep in the Rio Grande Plain of Texas. Texas Western, El Paso.

León, A., J. B. Chapa, and F. S. de Zamora

1961 Historia de Luevo León, con Noticias sobre Coahuila, Tamaulipas, Texas y Nueva México. Centrio de Estudios Humanistico. Universidad de Nuevo León, Monterrey.

Limerick, P. N.

1987 The Legacy of Conquest: The Unbroken Past of the American West. W. W. Norton, New York.

Lord, K. J.

1984 The Zooarchaeology of Hinds Cave (41VV456). Ph.D. dissertation, Department of Anthropology, The University of Texas at Austin.

Lundelius, E. L., Jr.

1984 A Late Pleistocene Mammalian Fauna from Cueva Quebrada, Val Verde County, Texas. In Contributions in Quaternary Vertebrate Paleontology, edited by H. H. Genoway and M. R. Dawson, pp. 456-481. Special Publication No. 8. Carnegie Museum of Natural History, Pittsburgh.

Mallouf, R. J., and C. Tunnell

1977 An Archeological Reconnaissance in the Lower Canyons of the Rio Grande. Texas Historical Commission, Austin.

Marks, M. K., J. C. Rose, and E. L. Buie

1985 Bioarcheology of Seminole Sink. In Seminole Sink: Excavation of a Vertical Shaft Tomb, Val Verde County, Texas, compiled by S. A. Turpin, pp. 99-152. Research Report 93. Texas Archeological Survey, The University of Texas at Austin.

Martin, G. C.

1933 Archaeological Exploration of the Shumla Caves. Bulletin No. 3. Witte Memorial Museum, San Antonio.

Martin, R. H.

1922 Del Rio As a Sheep and Goat Market. Sheep and Goat Raisers'Magazine 2(7):18-19.

Maslowski, R. F.

1978 The Archaeology of Moorehead Cave: Val Verde County, Texas. Unpublished Ph.D. dissertation, Department of Anthropology, University of Pittsburgh.

Maupin, J.

1974 Sheep and Goat Ranching, Texas Style. Oral Business History Project. Graduate School of Business. The University of Texas at Austin.

Mayer, E. S.

1938 The Wool Warehouse System of Texas. Southwest Sheep and Goat Raisers' Magazine 25(11):8-9, 25. 
McClurkan, B. B.

1980 The Archaeology of la Cueva de la Zona de Derrumbres (NL92): A Brief Summation and Suggestions for Future Research. In Papers on the Prehistory of Northeastern Mexico and Adjacent Texas, edited by J. F. Epstein, T. R. Hester, and C. Craves, pp. 59-71. Special Report, No. 9. Center for Archaeological Research, The University of Texas at San Antonio.

Miller, G. L.

1993 Some Thoughts on Classification of White Earthenwares. Council for Northeast Historical Archaeology Newsletter 26:4-7.

Miller, G. L., and A. Pacey

1985 Impact of Mechanization in the Glass Container Industry: The Dominion Glass Company of Montreal, a Case Study. Historical Archaeology 19(1):38-50.

Mock, S.

1987 The Painted Pebbles of the Lower Pecos: A Study of Medium, Form and Content. Master's thesis, The University of Texas at San Antonio.

Moir, R. W.

1987 Socioeconomic and Chronometric Patterning of Window Glass. In Historic Buildings, Material Culture, and People of the Prairie Margin: Architecture, Artifacts, and Synthesis of Historic Archaeology, vol. V, edited by D. H. Jurney and R. W. Moir, pp. 73-81. Archaeology Research Program, Institute for the Study of Earth and Man, Southern Methodist University, Dallas.

Montejano, D.

1987 Anglos and Mexicans in the Making of Texas, 1836-1986. University of Texas Press, Austin.

Moore, R. C.

1978 Treatise on Invertebrate Paleontology. The Geological Society of America, New York.

Moorhead, $\mathrm{M}$.

1975 The Presidio, Bastion of the Spanish Borderlands. University of Oklahoma Press, Norman.

Morris, E. H.

1922 Del Rio as an Automobile Center. Sheep and Goat Raisers' Magazine 2(7):36, 39-41.

Munsey, C.

1970 The Illustrated Guide to Collecting Bottles. Hawthorn Books, New York.

Natural Fibers Information Center

1987 The Climates of Texas Counties. The University of Texas at Austin.

National Park Service [NPS]

1993 Request for Proposal: Archaeological Inventory, National Register Evaluation and Documentation of Prehistoric and Historic Archaeological Resources at Lackland and Laughlin Air Force Base, Texas. Two volumes. Solicitation No. 1443-RP-1200-94-005. Rocky Mountain Region, National Park Service, Department of the Interior, Denver.

Newcomb, W. W., Jr.

1961 The Indians of Texas: From Prehistoric to Modern Times. University of Texas Press, Austin. 
Nordt, L. C.

1992 Archaeological Geology of the Fort Hood Military Reservation, Fort Hood, Texas. Research Report Number 25, Archaeological Resource Management Series. U.S. Army Fort Hood, Texas.

Nordt, L. C., T. W. Boutton, C. T. Hallmark, and M. R. Waters

1994 Late Quaternary Climate Changes in Central Texas Based on the Isotopic Composition of Organic Carbon, Quaternary Research 41:109-120.

Oberste, W. H.

1953 Texas Irish Empresarios and Their Colonies: Power and Heartson, McMullen and McGloir. Van Boeckmann-Jones, Austin.

Owen, J. G., and D. J. Schmidly

1986 Environmental Variables of Biological Importance in Texas. The Texas Journal of Science 38:99-119.

Parsons, J. L.

1962 Testing and Reconnaissance in Amistad, 1962. Manuscript on file, Texas Archaeological Research Laboratory, The University of Texas, Austin.

Parry, W. J., and R. L. Kelly

1987 Expedient Core Technology and Sedentism. In The Organization of Core Technology, edited by J. K. Johnson and C. A. Morrow, pp. 285-304. Westview, Boulder.

Patterson, P. E.

1980 Relocation and Restoration of A Baking Oven (Site 41VV588) in Val Verde County, Texas. Publications in Archeology, Report 18. Texas State Department of Highways and Public Transportation, Austin.

1987 Archeological Excavations at 41LL78, the Slab Site, Llano County, Texas. Publications in Archeology, Report 34. State Department of Highways and Public Transportation, Austin.

Patton, P. C., and D. S. Dibble

1982 Archaeologic and Geomorphic Evidence for the Paleohydrologic Record of the Pecos River in West Texas. American Journal of Science 282:97-121.

Pearce, J. E., and A. T. Jackson

1933 A Prehistoric Rockshelter in Val Verde County, Texas. Publication 3327. The University of Texas Austin.

Peck, J.

1991 An Analysis of the Projectile Points from the 1932 Excavation of Fate Bell Rockshelter. In Papers on Lower Pecos Prehistory, edited by S. A. Turpin, pp. 65-85. Studies in Archeology 8. Texas Archeological Research Laboratory, The University of Texas, Austin.

Peter, D. E., W. A. Cloud, C. Stiles-Hanson, and M. B. Cliff

1990 Intensive Survey Investigations of the Dughest Project, Val Verde County, Texas. Contract No. DACA6388-D-46. U.S. Army Corps of Engineers, Fort Worth.

Powell, J. F.

1991 Human Skeleton Remains from Skyline Shelter (41VV930), Val Verde County, Texas. In Papers on Lower Pecos Prehistory, edited by S. A. Turpin, pp. 149-173. Studies in Archeology 8. Texas Archeological Research Laboratory, The University of Texas, Austin. 
Prewitt, E. R.

1970 The Pedra Del Diablo Site, Val Verde County, Texas, and Notes on Some Trans-Pecos, Texas Archeological Material in The Smithsonian Institution, Washington, D.C. Archeological Report 18. Texas Historical Survey Committee. Austin.

1985 From Circleville to Toyah: Comments on Central Texas Chronology. Bulletin of the Texas Archeological Society 54:201-238.

Prewitt, E. R., and D. S. Dibble

1974 The San Felipe Creek Watershed Project, Val Verde County, Texas: An Archaeological Survey. Research Report No. 40. Texas Archeological Survey, The University of Texas at Austin.

Randall, H. S.

1860 Sheep Husbandry. Orange Judd, New York.

Raun, G. G.

1966 Preliminary Report on the Herpetofauna of Val Verde County. In A Preliminary Study of the Paleoecology of the Amistad Reservoir Area, assembled by D.A. Story and V. M. Bryant, Jr., pp. 191-192. Report submitted to the National Science Foundation.

Riskind, D. H.

1970 Pollen Analysis of Human Coprolites from Parida Cave. In Archeological Investigations at Parida Cave, Val Verde County, Texas. Papers of the Texas Archeological Salvage Project 19. The University of Texas at Austin.

Robbins, C. S., B. Bruun, and H. S. Zim

1963 A Guide to Field Identification: Birds of North America. Golden, New York.

Roenke, K. G.

1978 Flat Glass: Its Use as a Dating Tool for Nineteenth Century Archaeological Sites in the Pacific Northwest and Elsewhere. Memoir 4. Northwest Anthropology Research Notes, Moscow, Idaho.

Rogers, J.

1972 Plank Construction. In Architecture of the Texas Frontier, a Series of Papers Delivered at the 1972 Winedale Workshop, edited by D. Taylor, pp. 77-87. The Texas State Historical Survey Committee and The University of Texas at Austin Winedale Inn Properties, Winedale, Texas.

Ross, R. E.

1965 The Archeology of Eagle Cave. Papers of the Texas Archeological Salvage Project 7. The University of Texas at Austin.

Ruecking, F.

1953 The Economic System of the Coahuiltecan Indians of Southern Texas and Northeastern Mexico. Texas Journal of Science 5:480-497.

1954a Ceremonies of the Coahuiltecan Indians of Southern Texas and Northeastern Mexico. Texas Journal of Science 6:330-339.

1954b Bands and Band-clusters of the Coahuiltecan Indians of Southern Texas and Northeastern Mexico. Texas Journal of Science 7:357-388.

1955 The Coahuiltecan Indians of South Texas and Northeast Mexico. Master's thesis, The University of Texas at Austin. 
Salinas, M.

1990 Indians of the Rio Grands Delta. University of Texas Press, Austin.

Saunders, J. W.

1986 The Economy of Hinds Cave. Ph. D. dissertation, Department of Anthropology, Southern Methodist University, Dallas.

Sayles, E. B.

1935 An Archaeological Survey of Texas. Medallion Papers 17. Gila Pueblo, New Mexico.

Schuetz, M. K.

1956 An Analysis of Val Verde County Cave Material. Bulletin of the Texas Archeological Society 27:129-160.

1961 An Analysis of Val Verde County Cave Material: Part II. Bulletin of the Texas Archeological Society 31:167-205.

1963 An Analysis of Val Verde County Cave Material: Part III. Bulletin of the Texas Archeological Society 33:131-165.

1969 The History and Archaeology of Mission San Juan Capistrano, San Antonio, Texas. Volume II. Report No. 11. State Building Commission Archaeological Program, Highway Design Division, Austin.

Schuyler, R. L.

1991 Historical Archaeology in the American West: the View from Philadelphia. Historical Archaeology, 25(3):7-17.

Setzler, F. M.

1932 A Prehistoric Cave in Texas. Explorations and Field Work of the Smithsonian Institution, pp 133-140. Washington, D.C.

1933 Prehistoric Cave Dwellers of Texas, pp. 53-56. Explorations and Field Work of the Smithsonian Institution. Washington, D.C.

1934 Cave Burials in Southwest Texas. Explorations and Field Work of the Smithsonian Institution, pp. 35-37. Washington, D.C.

Shafer, H. J.

1975 Functional Interpretations of the Lower Pecos Archaic Art. Paper presented at the Reunion Sobre Aspectos de Arqueologia e Historia del Northeste. Monterrey, Nuevo Leon.

1977 Art and Territoriality in the Lower Pecos Region, Texas. Plains Anthropologist 22:13-22.

1980 Mouth of the Pecos. Manuscript on file. Department of Anthropology, Texas A\&M University, College Station.

1981 The Adaptive Technology of the Prehistoric Inhabitants of Southwest Texas. Plains Anthropologist 26:129-138.

1986 Ancient Texans: Rock Art and Lifeways along the Lower Pecos. Texas Monthly, Austin.

1988 The Prehistoric Legacy of the Lower Pecos Region of Texas. Bulletin of the Texas Archeological Society 59:23-52.

Shafer, H. J., and V. M. Bryant, Jr.

1977 Archaeological and Botanical Studies at Hinds Cave, Val Verde, County, Texas. Special Series, No. 1, Anthropology Laboratory. Texas A\&M University, College Station.

Sobolik, K. D.

1988 Diet Changes in the Lower Pecos: Analysis of Baker Cave Coprolites. Bulletin of the Texas Archeological Society 59:111-127. 
1991 Prehistoric Diet and Subsistence in the Lower Pecos as Reflected in Coprolites from Baker Cave, Val Verde County, Texas. Studies in Archeology 7, Texas Archeological Research Laboratory, The University of Texas at Austin.

Soil Survey Staff

1981 Soil Survey Manual. USDA-SCS Agricultural Handbook 18. U.S. Government Printing Office, Washington, D.C.

Sorrow, W. M.

1967 Test Excavations at the Nopal Terrace Site. Papers of the Texas Archeological Salvage Project, No. 15. The University of Texas at Austin.

1968 The Devil's Mouth Site: The Third Season, 1967. Papers of the Texas Archeological Salvage Project, No. 14. The University of Texas at Austin.

Stafford, B. G.

1922 The San Felipe Golf Course of Del Rio. Sheep and Goat Raisers ' Magazine 2(7):30-32.

Steele, D. G., and B. W. Olive

1989 Bioarcheology of Region 3 Study Area. In From the Gulf Coast to the Rio Grande: Human Adaptation in the Central, South, and Lower Pecos Texas, edited by T. R. Hester, S. L. Black, D. G. Steele, B. W. Olive, A. A. Fox, K. J. Reinhard, and L. C. Bement, pp. 93-114. Research Series No. 33. Arkansas Archeological Survey, Fayetteville.

Steen, R. W.

1948 The Texas Story. Steck, Austin.

Steinbomer, R. A.

1983 Brickmaking in Texas. Manuscript on file. San Antonio Conservation Society, San Antonio.

Stock, J. A.

1983 The Prehistoric Diet of Hinds Cave (41VV456), Val Verde County, Texas: The Coprolite Evidence. Master's thesis, Department of Anthropology, Texas A\&M University, College Station.

Story, D. A., and V. M. Bryant, Jr.

1966 A Preliminary History of the Paleoecology of the Amistad Reservoir Area. Final report submitted to the National Science Foundation (GS-667). The University of Texas at Austin.

Taylor, H. C., Jr.

1948 An Archaeological Reconnaissance in Northern Coahuila. Bulletin of the Texas Archeological and Paleontological Society 19:74-87.

1949 The Archaeology of the Area about the Mouth of the Pecos. Master's thesis, Department of Anthropology, The University of Texas at Austin.

The Texas Almanac and State Industrial Guide.

1933 A. H. Belo Corporation, Dallas.

Toomey, R. S. III, M. D. Blum, and S. Valastro, Jr.

1993 Late Quaternary Climates and Environments of the Edwards Plateau, Texas. Global and Planetary Change 7:299-320. 
Troike, R. C.

1961 Research in Coahuiltecan Ethnography. Bulletin of the Texas Archeological Society 30:301-310.

1962 Notes on Coahuiltecan Ethnography. Bulletin of the Texas Archeological Society 32:57-64.

Turner, E. S., and T. R. Hester

1993 A Field Guide to Stone Artifacts of Texas Indians. Second edition. Gulf, Houston.

Turpin, S. A.

1982 Seminole Canyon: The Art and the Archeology. Texas Archeological Survey Report Number 83. The University of Texas at Austin.

1984a Prehistory in the Lower Pecos: An Overview. Research Report 90. Texas Archeological Survey, The University of Texas at Austin.

1984b The Red Monochrome Style Pictographs of the Lower Pecos River Region, Texas. Bulletin of the Texas Archeological Society 55:123-144.

1984c The Red Linear Style Pictographs of the Lower Pecos River Region. Plains Anthropologist 29:181-198.

1986a The Red Monochrome Style and Later Pictographs: The Art of Newcomers to the Lower Pecos. In Ancient Texas: Rock Art and Lifeways Along the Lower Pecos, edited by H. J. Shafer, pp. 186-189. Texas Monthly Press, Austin.

1986b Towards a Definition of a Pictograph Style: the Lower Pecos Bold Line Geometric. Plains Anthropologist 31(112):153-161.

1989 The Iconography of Contact: Spanish Influence in the Rock Art of the Middle Rio Grande. In Columbian Consequences, edited by D. H. Thomas. Smithsonian Press, Washington, D.C.

1991 Time out of Mind: The Radiocarbon Chronology of the Lower Pecos River Region. In Papers on Lower Pecos Prehistory, edited by S.A. Turpin, pp. 1-50. Studies in Archeology 8. Texas Archeological Research Laboratory, The University of Texas at Austin.

1995 The Lower Pecos River Region of Texas and Northern Mexico. Bulletin of the Texas Archeological Society 66:541-560.

Turpin, S. A., and L. C. Bement

1985 The Site and Its Setting. In Seminole Sink: The Excavation of a Vertical Shaft Tomb, Val Verde County, Texas, compiled by S. A. Turpin, pp. 1-21. Research Report No. 93. Texas Archeological Survey, The University of Texas at Austin.

1988 The Live Oak Hole Complex: Plains Indian Art and Occupation in the Lower Pecos River Region. Bulletin of the Texas Archeological Society 59:65-82.

Turpin, S. A., and M. W. Davis

1990 The 1989 TAS Field School: Devils River State Natural Area. Bulletin of the Texas Archeological Society 61:1-58.

Turpin, S. A., M. Hanneberg, and D. K. Riskind

1986 Late Archaic Mortuary Practices of the Lower Pecos River Region, Southwest Texas. Plains Anthropologist 31(114):295-315.

Valdez, F. L.

1976 Dona Paula Losoya de Rivas (Rivers). In La Hacienda: An Official Bicentennial Publication. Whitehead Memorial Museum and the Val Verde Historical Commission, Del Rio, Texas.

Van Devender, T. R.

1990 Late Quaternary Vegetation and Climate of the Chihuahuan Desert, United States and Mexico. In Packrat Middens, edited by J. L. Betancourt, T. R. Van Devender, and P. S. Martin, pp.104-133. The University of Arizona Press, Tucson. 
Webb, W. P.

1952 The Handbook of Texas. Two volumes. Texas State Historical Association, Austin.

Weddle, R. S.

1968 San Juan Bautista: Gateway to Spanish Texas. University of Texas Press, Austin.

Wentworth, E. N.

1938 The Story of Texas Sheep. Cattleman 25(11):47-51.

Whitehead Memorial Museum and the Val Verde Historical Commission [WMM/VVCHC]

1976 La Hacienda: An Official Bicentennial Publication. Whitehead Memorial Museum and the Val Verde Historical Commission, Del Rio, Texas.

Whittaker, R. H., G. E. Likens, and H. Lieth

1975 Scope and Purpose of this Volume. In Primary Productivity of the Biosphere, edited by H. Leith and R. H. Whittaker, pp. 3-5. Springer-Verlag, New York.

Williams-Dean, G. J.

1978 Ethnobotany and Cultural Ecology of Prehistoric Man in Southwest Texas. Ph.D. Dissertation, Department of Botany, Texas A\&M University.

Winkler, B. A.

1982 Wild Plant Foods of the Desert Gatherers of West Texas, New Mexico and Northern Mexico: Some Nutritional Values. Master's thesis, Department of Anthropology, The University of Texas at Austin.

Wooster, R.

1987 Soldiers, Sutlers, and Settlers, Garrison Life on the Texas Frontier. Texas A\&M University Press, College Station.

Word, J. H., and C. L. Douglas

1970 Excavations at Baker Cave, Val Verde County, Texas. Bulletin of the Texas Memorial Museum 16, Austin.

Wulfkuhle, V. A.

1986 The Buttrill Ranch Complex: Evidence of Early Ranching in the Big Bend. Report No. 34. Office of the State Archeologist. Texas Historical Commission, Austin.

York, D. A.

1922 Del Rio's Climate and Homes. Sheep and Goat Raisers' Magazine 2(7):24-25.

Young, W. C.

1981 Investigations at the Squateat Peak Site, Pecos County, Texas. Publications in Archaeology Report No. 20. Texas State Department of Highways and Public Transportation, Austin.

1982 Excavations at the Ram's Head Site, 41PC35, Pecos County, Texas. Publications in Archaeology Report No. 23. Texas State Department of Highways and Public Transportation, Austin. 


\title{
APPENDIX A \\ GEOMORPHOLOGICAL DATA
}

\author{
Lee C. Nordt
}

Trench 1; upland valley fill; $1-2 \%$ slope; calcareous throughout; $0-46 \mathrm{~cm}$ is Holocene undifferentiated and $46-160 \mathrm{~cm}$ is Unit I (Pleistocene).
A $\quad 0-23 \mathrm{~cm}$
very dark brown (10YR 3/2.5) silty clay; moderate medium subangular blocky; friable; $8-10 \%$ coarse fragments $0.3-1 \mathrm{~cm}$ in diameter, a wedge of coarse angular gravels enters trench from upslope; gradual smooth.
Bw 23-46 cm dark brown (10YR 3/3) silty clay; 8\% strong brown (7.5YR 4/6) iron oxide pore coats; moderate coarse angular blocky; friable; coarse fragments (see above); abrupt smooth.
Bkmb1 46-64 cm brown (7.5YR 5/3); discontinuously indurated petrocalcic, $70 \% \mathrm{CaCO}_{3}$; abrupt smooth.
Bk1b2 64-87 cm pale brown (10YR 6/3) silty clay loam; weak coarse angular blocky; slightly hard; few fine coarse fragments.
Bk2b2 87-160 very pale brown (10YR 7/3) silty clay loam; weak coarse angular blocky; hard; $15 \%$ soft, white $\mathrm{CaCO}_{3}$ masses.

Trench 2; upland valley fill; $0-1 \%$ slope; calcareous throughout; $0-63 \mathrm{~cm}$ is Holocene undifferentiated and 63-180 cm is Unit I (Pleistocene).

A 0-27 cm very dark grayish brown (10YR 3/2) silty clay; moderate medium subangular blocky; friable; $5 \%$ coarse fragments $0.3-0.8 \mathrm{~cm}$ diameter; gradual smooth.

Bw 27-48 cm dark brown (10YR 3/3) silty clay loam; moderate medium subangular blocky; friable; coarse fragments (see above); gradual smooth.

Bk1 48-63 cm brown (10YR 4.5/3) silty clay; moderate coarse angular blocky; friable; 20\% pinkish brown $\mathrm{CaCO}_{3}$ nodules, 4-10 $\mathrm{mm}$ in diameter; abrupt smooth.

$\mathrm{Bkmb1} \quad 63-74 \mathrm{~cm}$ discontinuously indurated petrocalcic, $80 \% \mathrm{CaCO}_{3}$; abrupt smooth.

Bk1b2 74-111 cm pale brown (10YR6/3) silty clay loam; moderate coarse angular blocky; friable; $15-20 \%$ white $\mathrm{CaCO}_{3}$ nodules $0.5-1.5 \mathrm{~cm}$ diameter; abrupt smooth.

Bk2b2 111-185 cm very pale brown (10YR 7/3) silty clay loam; weak coarse angular blocky; friable; $60 \%$ soft white $\mathrm{CaCO}_{3}$ masses. 
Trench 3 (full of water; abbreviated description); TO of Sacatosa Creek; 0-1\% slope; calcareous throughout; Unit VI is $0-15 \mathrm{~cm}$ and consists of a loamy and light colored A horizon; Unit V is $15-60+\mathrm{cm}$ and consists of very dark grayish brown, clayey, Ab and Bgb horizons (15-35 cm depth) over $25 \mathrm{~cm}(35-60+\mathrm{cm}$ depth) of a graveliferous clay loam.

Trench 4; TO alluvial fan of Sacatosa Creek; 0-1\% slope; calcareous throughout; Unit VI is 0-21 cm, Unit IV is $21-122 \mathrm{~cm}$, Unit II is $122-280 \mathrm{~cm}$.

A 0-21 cm very dark grayish brown (10YR 3/2) clay loam; few medium brown (10YR 4/3) redox depletions; moderate medium subangular blocky; firm; common sand-size carbonates; abrupt smooth.

Ab1 21-47 cm very dark gray (10YR 3.5/1) heavy clay loam; moderate medium subangular blocky; firm; gradual smooth.

Bw1b1 47-81 cm brown (10YR 5/3) clay loam; few medium distinct brownish yellow (10YR 6/6) redox concentrations; moderate coarse angular blocky; firm; 3-5\% coarse fragments, 2-5 mm in diameter, increasing slightly with depth; gradual smooth.

Bw2b1 81-122 cm brown (10YR 5.5/3) clay loam; moderate coarse angular blocky; firm; 15-20\% coarse fragments 3-8 $\mathrm{mm}$ in diameter; abrupt smooth; bulk humate sample from 95-105 cm carbon-14 dating to $3320 \pm 70$ (Beta 73178).

Bkb2 122-152 cm brown (10YR 5/3) clay; common medium distinct brownish yellow (10YR 6/6) redox concentrations; moderate coarse angular blocky; very firm; $5 \%$ coarse fragments 3-4 mm in diameter; $5 \%$ white and soft $\mathrm{CaCO}_{3}$ nodules, $4-8 \mathrm{~mm}$ in diameter; colors become grayer with depth.

Trench 5; TO of Sacatosa Creek; 0-1\% slope; calcareous throughout; Unit VI is 0-11 cm, Unit V is $11-110 \mathrm{~cm}$, Uvalde Gravel is below $89 \mathrm{~cm}$.

A $\quad$ 0-11 cm very dark gray (10YR 3/1) silty clay; moderate medium subangular blocky; firm; clear smooth.

Ab1 11-27 cm very dark grayish brown (10YR 2.5/1) silty clay; moderate fine to medium subangular blocky; firm; gradual smooth.

Bgb1 27-72 cm very dark grayish brown (10YR3/1) silty clay; $2-3 \%$ gravels (mostly siliceous) $0.5-1 \mathrm{~cm}$ diameter, increasing slightly with depth; $10 \%$ coarse fragments $2-3 \mathrm{~mm}$ in diameter; gradual smooth; bulk humate sample from $62-72 \mathrm{~cm}$ carbon-14 dating to $1750 \pm 70$ (Beta 73179 ).

BCgb1 72-89 cm dark gray (10YR 3.5/1); moderate medium subangular blocky; firm; $15 \%$ gravels (mostly siliceous) $0.3-1 \mathrm{~cm}$ diameter.

Ckmb2 89-110 cm Uvalde Gravel (caliche); moderately well sorted carbonate clasts $1-4 \mathrm{~cm}$ in diameter and subrounded. 
Trench 6; T2 of Sacatosa Creek; $1-2 \%$ slope; Unit II (eolian?) is $0-45 \mathrm{~cm}$, Unit 1 is $45-160 \mathrm{~cm}$; calcareous throughout; trench is in middle of site VV1654.
A $\quad 0-23 \mathrm{~cm}$
dark grayish brown (1OYR 4/2) light clay loam; moderate medium subangular blocky; friable; $5 \%$ fine coarse fragments; gradual smooth.
Bw 23-45 cm grayish brown (10YR 4.5/2); moderate medium subangular blocky; friable; 5-6\% fine coarse fragments; clear smooth.
Bklb 45-88 cm pale brown (10YR 6/3) silty clay loam; moderate coarse angular blocky; firm; few fine coarse fragments; 4-5\% soft white soft $\mathrm{CaCO}_{3}$ masses; clear smooth.
$\mathrm{Bk} 2 \mathrm{~b} \quad 88-160 \mathrm{~cm}$
very pale brown (10YR7/3) silty clay loam; moderate coarse angular blocky; firm; few coarse fragments $0.5-1 \mathrm{~cm}$ in diameter; $50 \%$ soft white $\mathrm{CaCO}_{3}$ masses.

Trench 7; alluvial fan in TO of Sacatosa Creek; 0-1\% slope; calcareous throughout; few diffuse siliceous gravels throughout; water table at $127 \mathrm{~cm}$; Unit V.

A $\quad$ 0-25 cm black (10YR 2/1) silty clay; strong fine subangular blocky; very friable; gradual smooth.

$\mathrm{Bw} \quad 25-45 \mathrm{~cm} \quad$ very dark grayish brown (10YR 3/2) silty clay; moderate medium subangular blocky; friable; gradual smooth.

Bg $\quad 45-78 \mathrm{~cm} \quad$ brown (10YR 5/3) silty clay; moderate medium angular blocky; friable; gradual smooth.

Bkg 78-127 cm light brownish gray (10YR 6/2) silty clay; weak coarse angular blocky; friable; 2-3\% soft white $\mathrm{CaCO}_{3}$ masses.

Trench 8; TO of Sacatosa Creek; 0-1\% slope; calcareous throughout; Unit V; Uvalde Gravel at $140 \mathrm{~cm}$; abbreviated description.
A
$0-9 \mathrm{~cm}$
very dark gray (10YR 3/1) clay; $20 \%$ gray $(10 \mathrm{YR} 5 / 1)$.
$\mathrm{Ab}$
$19-33 \mathrm{~cm}$
black (10YR 2/1) clay; $20 \%$ dark gray (10 YR 4/1).
Bglb1 33-43 cm
dark gray (10 YR 3.5/1) heavy silty clay loam; few fine iron oxide pore coats.
Bg2b1 43-64 cm gray (10YR 4.5/1) silty clay loam; few fine iron oxide pore coats.
BCgb1 64-140 cm light gray (10YR 6/1) silt loam.
Ckmb2 $\quad 140+\quad$ Uvalde Gravel.

Trench 9; same as Trench 8. 
Trench 10; TO of Zorro Creek; 0-1\% slope; calcareous throughout; Unit IV, V or VI is $0-13 \mathrm{~cm}$, Unit III is $13-165 \mathrm{~cm}$.

A $\quad 0-13 \mathrm{~cm} \quad$ very dark grayish brown (10YR 2.5/2) clay; moderate medium subangular blocky; firm; $3-4 \%$ siliceous gravels $3-5 \mathrm{~mm}$ in diameter occasionally concentrated in bottom of horizon; abrupt smooth.

$\mathrm{Ab} \quad 13-30 \mathrm{~cm} \quad$ black (10YR 2/1) clay; moderate medium subangular blocky; firm; few siliceous gravels 3-5 mm in diameter; gradual smooth.

Bwb 30-70 cm dark grayish brown (10YR 4/2) clay; weak coarse angular blocky; very firm; gravels same as above; clear smooth.

Bklb 70-132 cm yellowish brown (10YR 5/4) silty clay; weak coarse angular blocky; firm; same gravels as above; $3-4 \%$ filaments and threads of $\mathrm{CaCO}_{3}$; gradual smooth.

Bk2b 132-165 cm yellowish brown (10YR 5/4) silty clay; weak coarse angular blocky; friable; $1 \%$ filaments and threads of $\mathrm{CaCO}_{3} ; 3 \%$ fine gravels.

Trench 11; TO of Zorro Creek; 0-1\%; calcareous throughout; Unit IV, V or VI is 0-13 cm, Unit III is $13-152$ $\mathrm{cm}$; old Trench $1110 \mathrm{~m}$ to east contained a thick graveliferous channel deposit.

A $\quad$-13 cm very dark grayish brown (10YR 3/2) clay; few fine iron oxide pore coats; moderate medium platy; firm; abrupt smooth.

$\mathrm{Ab} \quad$ 13-34 cm very dark gray (10YR 3/1) clay; moderate medium subangular blocky; firm; 1-2\% coarse fragments $0.5-2 \mathrm{~cm}$ in diameter and concentrated at base of horizon; gradual smooth.

$\mathrm{Bgb} \quad 34-80 \mathrm{~cm} \quad$ dark gray (10YR 4/1) clay; $20 \%$ grayish brown (10YR 5/2); few fine iron oxide pore coats; weak coarse prismatic; very firm; $5 \%$ coarse fragments $4-8 \mathrm{~cm}$ in diameter; gradual smooth.

Bwlb $\quad 80-116 \mathrm{~cm} \quad$ light yellowish brown (10YR 6/4) silty clay; $10 \%$ light gray (10YR 7/2); weak coarse prismatic; very firm; gradual smooth.

Bw2b 116-150 cm pale brown (10YR 6.5/3) silty clay; weak coarse prismatic; very firm. 
Trench 12; TO of Zorro Creek; $0-1 \%$ slope; calcareous throughout; Unit IV, V or VI is $0-15 \mathrm{~cm}$, Unit III is $15-190 \mathrm{~cm}$.

A $\quad 10-15 \mathrm{~cm} \quad$ olive brown (2.5Y 3/3) clay; strong medium subangular blocky; very hard; 3-4\% coarse fragments 4-8 $\mathrm{mm}$ in diameter; clear smooth.

A2 $\quad 15-37 \mathrm{~cm} \quad$ olive brown $(2.5 \mathrm{Y} 4 / 3)$ clay; weak coarse angular blocky; very firm; $5 \%$ coarse fragments $2-8 \mathrm{~mm}$ in diameter; gradual smooth.

Bw1 $\quad 37-70 \mathrm{~cm} \quad$ olive brown (2.5Y 4/4) clay; weak coarse angular blocky; firm; $5 \%$ coarse fragments $2-4 \mathrm{~mm}$ in diameter; clear smooth.

Bw2 70-119 cm light olive brown (2.5Y 5/4) clay; weak coarse angular blocky; very hard; 4-5\% coarse fragments $2-3 \mathrm{~mm}$ in diameter; gradual smooth.

Bk $\quad 119-159 \mathrm{~cm} \quad$ olive brown (2.5Y 4/4) clay; $20 \%$ light yellowish brown (2.5Y 6/4); weak coarse prismatic; very firm; $2 \%$ coarse fragments $2-4 \mathrm{~mm}$ in diameter; $5 \%$ soft pink $\mathrm{CaCO}_{3}$ masses $1 \mathrm{~cm}$ in diameter.

Bky $\quad 159-190 \mathrm{~cm} \quad$ light olive brown (2.5Y 5/4) sandy clay; 30\% pale yellow (2.5Y 7/4); weak coarse prismatic; very hard; $2 \%$ coarse fragments like above; $1 \%$ iron manganese concretions $3-4 \mathrm{~mm}$ in diameter; $8 \%$ soft white $\mathrm{CaCO}_{3}$ masses $1 \mathrm{~cm}$ in diameter; $8 \%$ common fine gypsum crystals.

Trench 13; alluvial fan (gully fill) inset to T2 of Sacatosa Creek; $2-3 \%$ slope; Unit IV is about 0-120 cm, Unit I is $120-155+\mathrm{cm}$. Description written partly from a hand auger.

$\mathrm{A} \& \mathrm{AB} \quad 0-53 \mathrm{~cm} \quad$ very dark grayish brown (10YR 2.5/2) silty clay; moderate medium subangular blocky; firm.

Bw1 $\quad 53-75 \mathrm{~cm} \quad$ dark brown (10YR 3/3) silty clay.

Bw2 76-120 cm light yellowish brown (10YR 6/4) silty clay.

Bklb $\quad 120-155 \mathrm{~cm} \quad$ pink (7.5YR 7/4) silty clay; few fine white $\mathrm{CaCO}_{3}$ nodules.

$\mathrm{Bk} 2 \mathrm{~b} \quad 155+\mathrm{cm} \quad$ same as above but with $20-30 \%$ white $\mathrm{CaCO}_{3}$ nodules.

Gully-Cut 1 (GC1); T1 of Sacatosa Creek; 1-2\% slope; calcareous throughout; Unit III.

A $\quad$ 0-28 cm dark brown (10YR 3/3) clay; weak coarse subangular blocky; firm; 2-3\% coarse fragments $0.5-3 \mathrm{~cm}$ diameter; clear smooth.

Bw 28-48 cm yellowish brown (10 YR 5/4) clay; weak coarse angular blocky; firm; $15 \%$ coarse fragments $0.5-1 \mathrm{~cm}$ diameter; abrupt wavy.

C $\quad 48-123 \mathrm{~cm} \quad 70 \%$ coarse fragments $0.5-5 \mathrm{~cm}$ diameter; matrix color is light yellowish brown (10YR 5/4); angular gravels; gravel supported and moderately well sorted. 


\section{APPENDIX B \\ PALEONTOLOGICAL DATA}

\section{James O. Jones}

Table B-1. Microfossils Recovered from the Del Rio Formation

Location on Slide

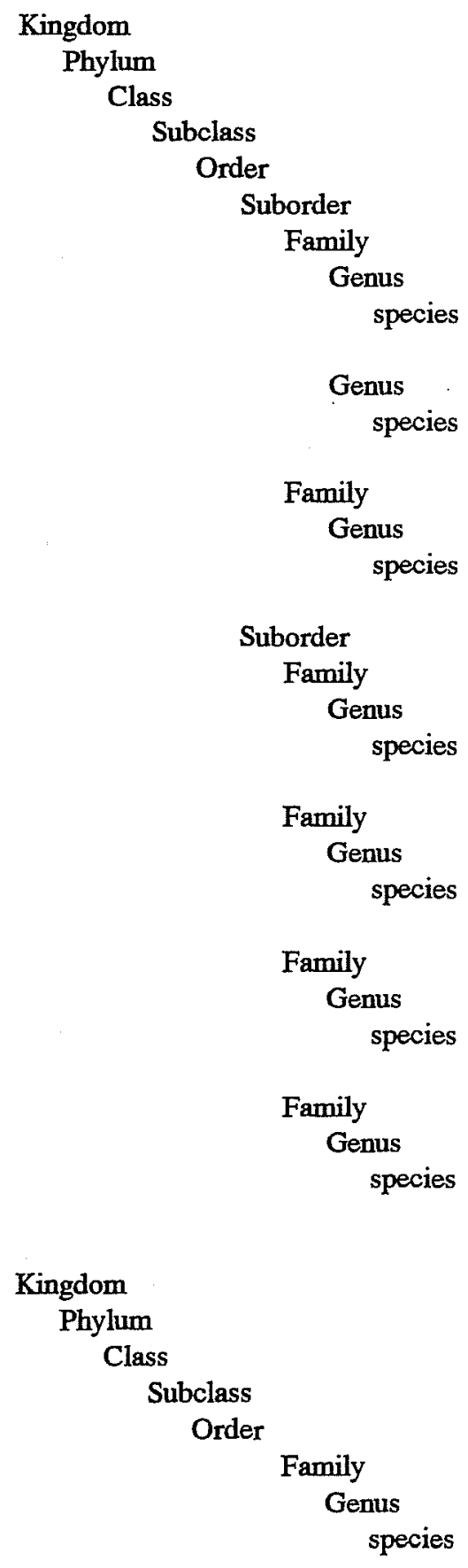

Protista

Protozoa

Rhizopoda

Foraminifera

Foraminiferida

Rotaliina

Nodosariidae

Lenticulina

cf. jonesi

1

Lenticulina

gaultina

$5 \& 6$

Globigerinidae

Globigerina

delrioensis

31

Textulariina

Trochamminidae

Trachammina

sp.

4

Textulariidae

Textularia

sp.

Lituolidae

Flabellammina

alexanderi

30

Hormosinidae

Cribratina

texana

(Not on slide)

Animalia

Arthropoda

Crustacea

Ostracoda

Podocopida

Cytherellidae

Cytherella

scotti 


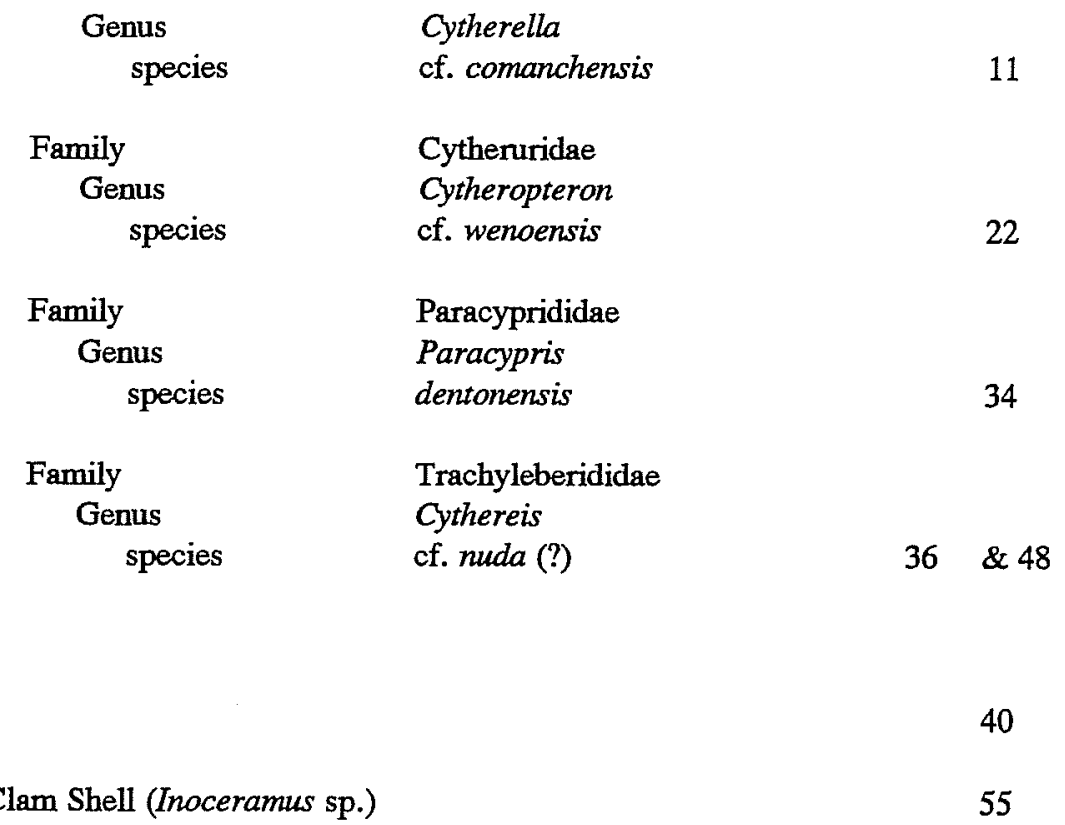

Cluster of Prisms, Clam Shell (Inoceramus sp.) 
Table B-2. Megafossils in the Del Rio Formation

\begin{tabular}{|c|c|c|}
\hline Kingdom & & Animalia \\
\hline Phylum & & Mollusca \\
\hline Class & & Pelecypoda \\
\hline & Order & Oyster \\
\hline & Family & Gryphaeidae \\
\hline & Genus & Illymatogyra \\
\hline & species & arietina \\
\hline & Order & Trigoniidae \\
\hline & Family & Cardiidae \\
\hline & Genus & Protocardia \\
\hline & species & hillana (?) \\
\hline & Order & Pterioida \\
\hline & Family & Inoceramidae \\
\hline & Genus & Inoceramus \\
\hline & species & sp. \\
\hline & Order & Arcoida \\
\hline & Family & Arcidae \\
\hline & Genus & Barbatia \\
\hline & species & barbata (?) \\
\hline & Order & Pterioida \\
\hline & Family & Gryphaeida \\
\hline & Genus & Exogyra \\
\hline & species & costata (ponderosa?) \\
\hline & Order & Pterioida \\
\hline & Family & Gryphaeida \\
\hline & Genus & Ostrea \\
\hline & species & sp. \\
\hline & Order & Pterioida \\
\hline & Family & Plicatulidae \\
\hline & Genus & Plicatula \\
\hline & species & plicatula \\
\hline & Order & Pterioida \\
\hline & Family & Pectinidae \\
\hline & Genus & Neitheops \\
\hline & species & cf. grandicosta \\
\hline & Order & Trigonoidea \\
\hline & Family & Trigoniidae \\
\hline & Genus & Trigonia \\
\hline & species & sp. \\
\hline Phylum & & Mollusca \\
\hline Class & & Cephalopoda \\
\hline & Order & Ammonoidea \\
\hline & Family & Turrilitidae \\
\hline & Genus & Mariella (Pleisoturrilites) \\
\hline & species & sp. \\
\hline
\end{tabular}




$\begin{array}{cl}\begin{array}{c}\text { Family } \\ \text { Genus } \\ \text { species }\end{array} & \begin{array}{l}\text { Engonoceratidae } \\ \text { Metengonoceras } \\ \text { inscriptum }\end{array} \\ \text { Family } & \begin{array}{l}\text { Brancoceratidae } \\ \text { Genus }\end{array} \\ \text { species } & \begin{array}{l}\text { Mortoniceras (Durnovarites) } \\ \text { perinflata }\end{array}\end{array}$

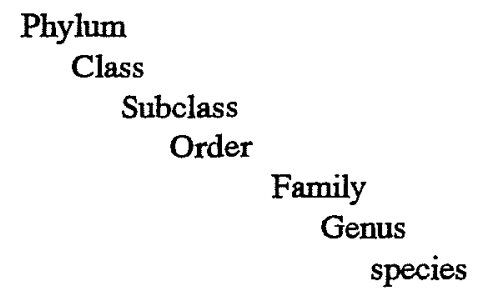

Echinodermata

Echinoidea

Irregularia

Spatangoidea

Toxasteridae (?)

Heteraster (?) (Enallaster)

Phylum

Class

Order

Family

Genus

species

sp.

Annelida

Polychaetia

Sedentaria

Serpulidae

Serpula

vermicularis

Genus
species

Hamulus

onyx (?)

Phylum

Class

Order

Family

Genus

species

Mollusca

Gastropoda

Mesogastropoda

Cerithiadae

Turritella

sp.

Spherical structures $=$ probably algal

Numerous burrows in sandstone beds $=$ Paleophycus (animal that caused them unknown)

Numerous borings in shells = sponge (?)

Symmetrical ripplemarks, oscillation current generated, associated with crossbedding, one inch crests and three inches between crests 
Table B-3. Microfossils Recovered from the Buda Formation

Location on Slide

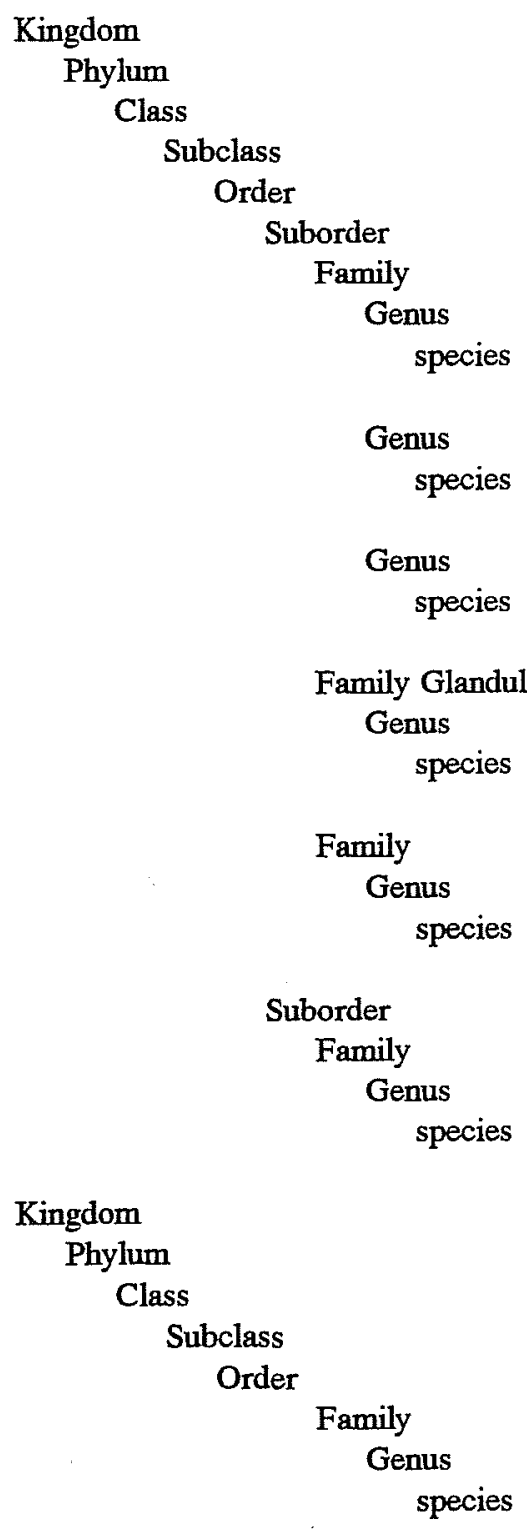

Protista

Protozoa

Rhizopoda

Foraminifera

Foraminiferida

Rotaliina

Nodosariidae

Lagena

hispida (?)

1

Lenticulina

cyprina

7

Lenticulina

cf. gaultina

5

Tristix

acutangula (?)

4

Globigerinidae

Globigerina

delrioensis

6

Textulariina

Lituolidae

Textularia

sp.

2

Animalia

Arthropoda

Crustacea

Ostracoda

Pododcopida

Cytherellidae

Cytherella

scotti

10 
Table B-4. Megafossils in the Buda Formation

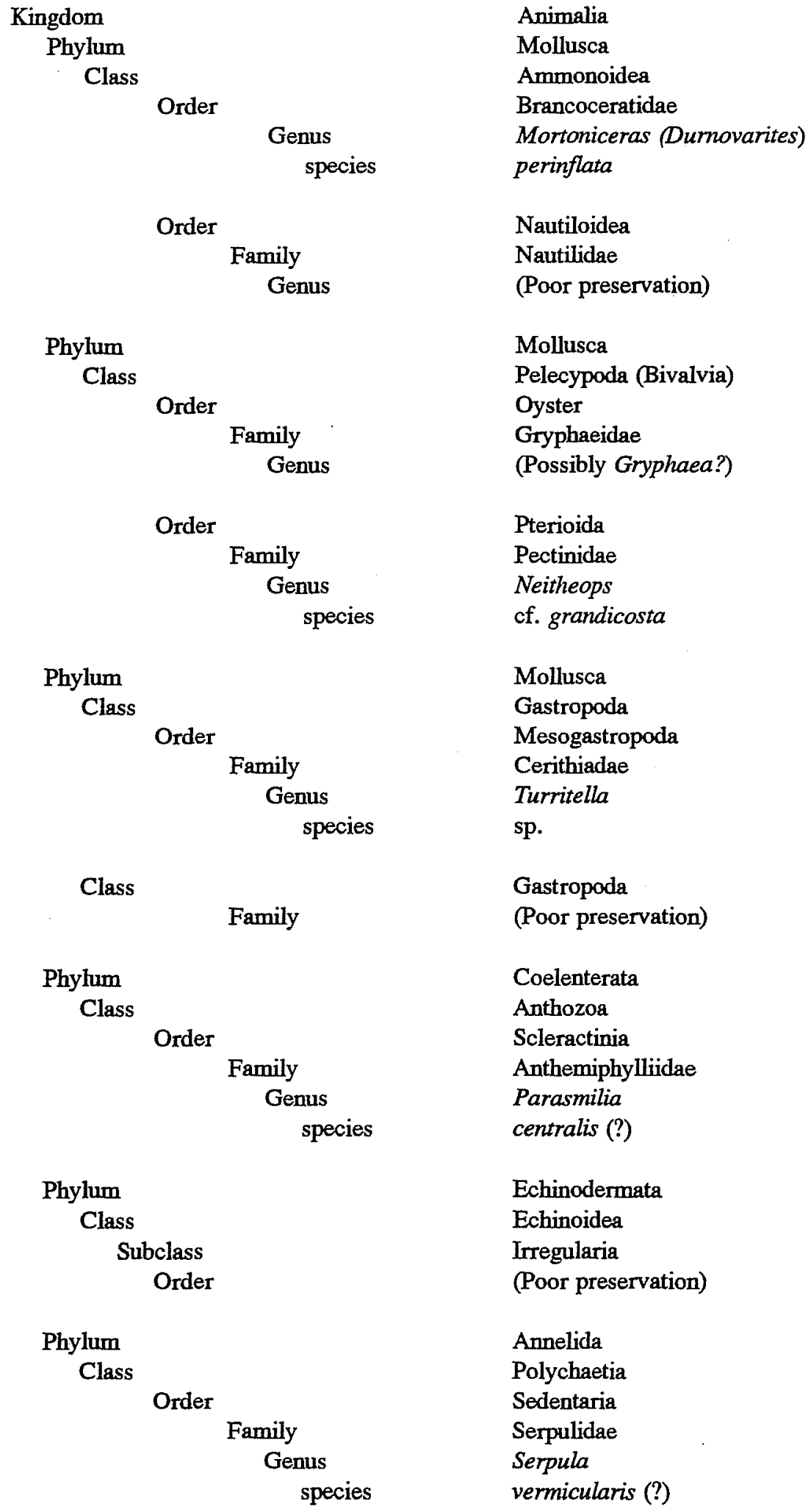

Fish, two inches, no head, found in Uvalde Gravel above Buda Limestone, lithologically appears to be Buda Limestone, stratigraphic horizon uncertain.

Burrows $=$ Paleophycus (animal which caused them is unknown) 
Table B-5. Mega- and Microfossils in the Salmon Peak Formation

(Lake Amistad Marina)

\section{Megafossils}

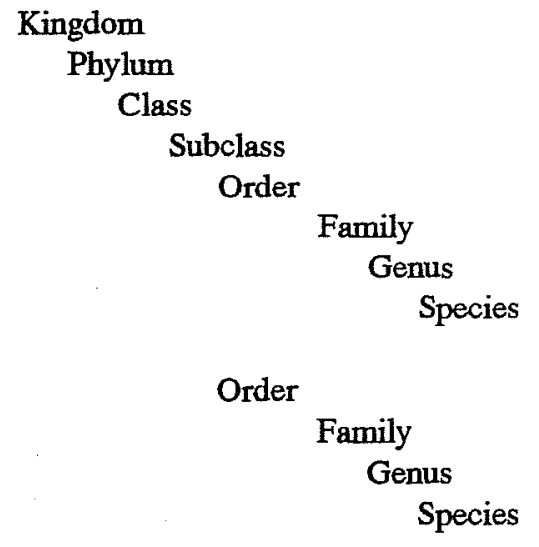

Class

Order
Family
Genus
species

Microfossils

Kingdom

Phylum

Class

Order

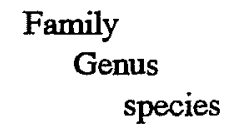

\author{
Animalia \\ Mollusca \\ Pelecypoda (Bivalvia) \\ Heterodonta \\ Hippuritoida \\ Caprinidae \\ (Poor preservation) \\ sp.
}

Pterioida

Gryphaeida

(Poor preservation, probably Exogyra, Ostrea, and Gryphaea)

sp.

\author{
Cephalopoda \\ Ammonoidea \\ Brancoceratidae \\ Mortoniceras (Durnovarites) \\ sp.
}

Protista

Protozoa

Rhizopoda

Foraminiferida

Globigerinidae

Globigerina

sp.

NOTE: Lake Amistad water level was down $23 \mathrm{ft}$ and all recently exposed rock was covered with calcium carbonate and no fossils were observable except by breaking the rocks. Therefore, only poorly observable specimens were available. Above normal pool level numerous specimens are present. 


\section{APPENDIX C \\ FORMS}

In addition to the standard State of Texas Site Data form which was completed for each site on Laughlin AFB, numerous forms were developed specifically for the Laughlin survey. The latter are included in this appendix. 
Center for Archaeological Research - UTSA

L \& L Project - Laughlin Phase

COLLECTION BAG LOG

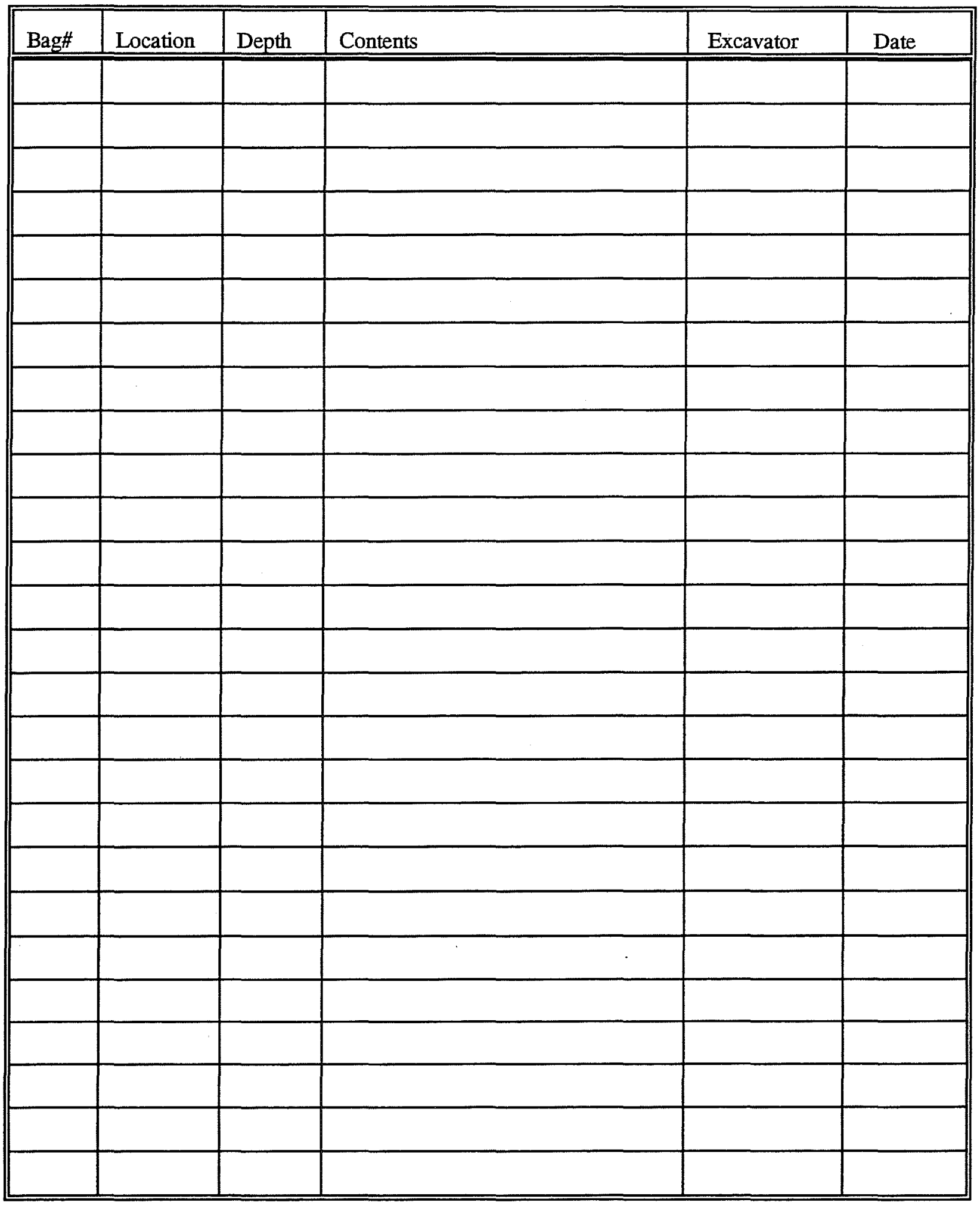


Center for Archaeological Research - UTSA

L \& L Project - Laughlin Phase

FEATURE LOG

\begin{tabular}{|c|c|c|c|c|}
\hline Feature\# & Provenience & Description & Excavator & Date \\
\hline & & & & \\
\hline & & & & \\
\hline & & & & \\
\hline & & & & \\
\hline & & & & \\
\hline & & & & \\
\hline & & & & \\
\hline & & & & \\
\hline & & & & \\
\hline & & & & \\
\hline & & & & \\
\hline & & & & \\
\hline & & & & \\
\hline & & & & \\
\hline & & & & \\
\hline & & & & \\
\hline & & & & \\
\hline & & & & \\
\hline & & & & \\
\hline & & & & \\
\hline & & & & \\
\hline & & & & \\
\hline & & & & \\
\hline & & & & \\
\hline & & & & \\
\hline & & & & \\
\hline
\end{tabular}


Center for Archaeological Research - UTSA

L \& L Project - Lackland Phase

ISOLATED FIND LOG

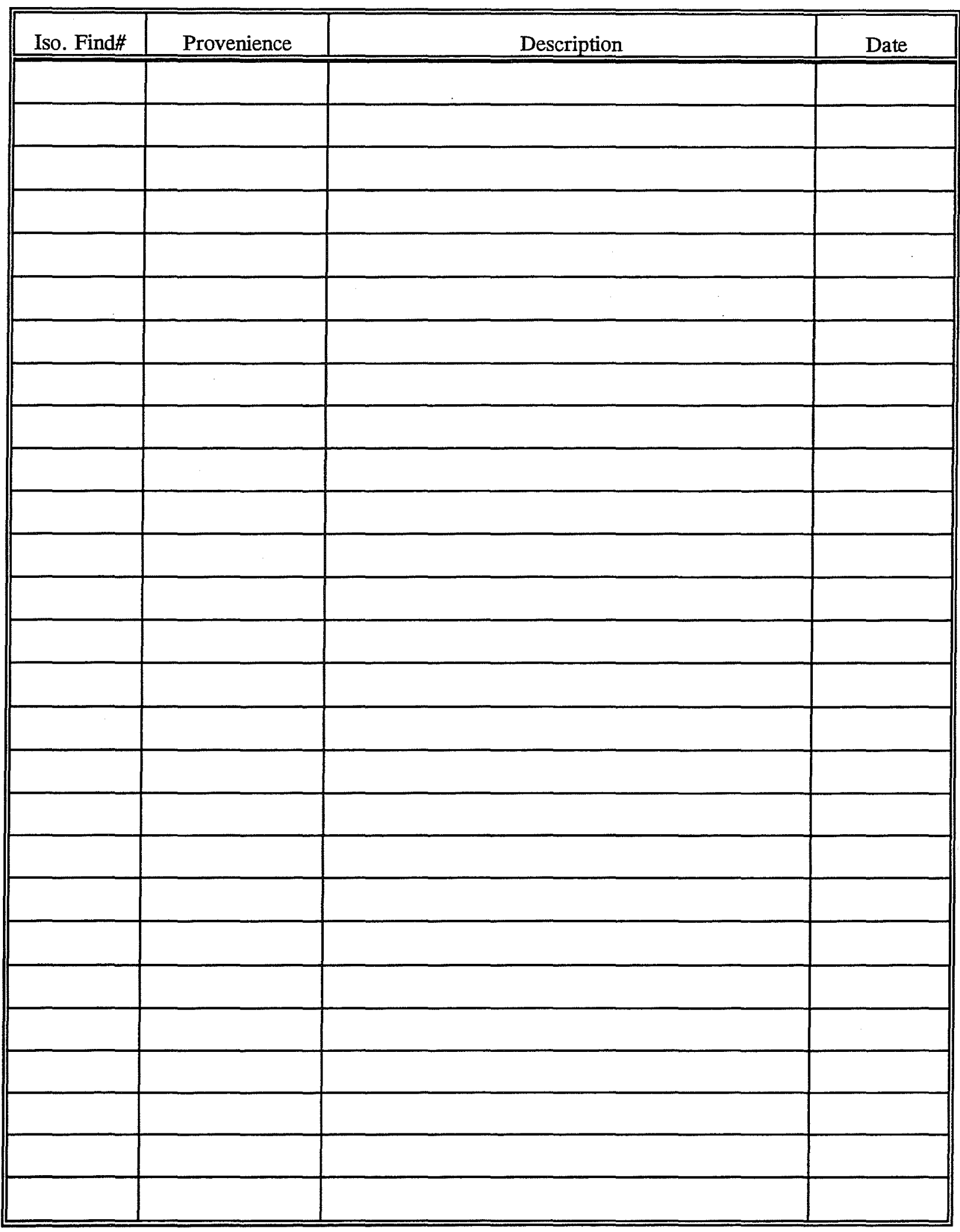


Center for Archaeological Research - UTSA

L \& L Project - Laughlin Phase

ISOLATED FIND FORM

Iso. Find \#

Dimension: N/S

$E / W$

Recorder

Date

Location

Natural Setting

Artifacts

Area Integrity

Shovel Probe $\mathrm{Y}_{-} / \mathrm{N}$

if Yes: Total Depth

Artifact

Depth

Artifact

Depth

Artifact

Depth

Artifact

Depth

\section{Comments:}


CENTER FOR ARCHAEOLOGICAL RESEARCH - UTSA

L \& L Project - Laughlin Phase

SHOVEL TEST FORM

SITE \#

DATE

UNIT \#

LOCATION

EXCAVATOR

LEVEL 1. $(0-10 \mathrm{~cm}) \quad$ Bag\#

Artifacts

Soil Desc.

\% Gravels

Comments

LEVEL 2. $(10-20 \mathrm{~cm})$ Bag\#

Artifacts

Soil Desc.

\% Gravels

Comments

LEVEL 3. $(20-30 \mathrm{~cm})$ Bag\#

Artifacts

Soil Desc.

\% Gravels

Comments

LEVEL 4. (30-40cm) Bag\#

Artifacts

Soil Desc.

\%Gravels

Comments

LEVEL 5. $(30-40 \mathrm{~cm}) \quad$ Bag\#

Artifacts

Soil Desc.

\%Gravels

Comments 
Center for Archaeological Research - UTSA

L \& L Project - Laughlin Phase

SPECIAL SAMPLE LOG

\begin{tabular}{|c|c|c|c|c|}
\hline Sample \# & Provenience & Description & Excavator & Date \\
\hline & & & & \\
\hline & & & & \\
\hline & & & & \\
\hline & & & & \\
\hline & & & & \\
\hline & & & & \\
\hline & & & & \\
\hline & & & & \\
\hline & & & & \\
\hline & & & & \\
\hline & & & & \\
\hline & & & & \\
\hline & & & & \\
\hline & & & & \\
\hline & & & & \\
\hline . & & & & \\
\hline & & & & \\
\hline & & & & \\
\hline & & & & \\
\hline & & & & \\
\hline & & & & \\
\hline & & & & \\
\hline & & & & \\
\hline & & & & \\
\hline & & & & \\
\hline
\end{tabular}


Center for Archaeological Research - UTSA

L \& L Project - Laughlin AFB

PHOTOGRAPHIC LOG

Color [ ] Black/ White [ ] Print [ ] Slide [ ] Film Type

Roll \#

\begin{tabular}{|c|c|c|c|c|}
\hline Frame \# & Description & Facing & Name & Date \\
\hline & & & & \\
\hline & & & & \\
\hline & & & & \\
\hline & & & & \\
\hline & & & & \\
\hline & & & & \\
\hline & & & & \\
\hline . & & & & \\
\hline & & & & \\
\hline & & & & \\
\hline & & & & \\
\hline & & & & \\
\hline & & & & \\
\hline & & & & \\
\hline & & & & \\
\hline & & & & \\
\hline & & & & \\
\hline & & & & \\
\hline & & & & \\
\hline & & & & \\
\hline & & & & \\
\hline & & & & \\
\hline & & & & \\
\hline & & & & \\
\hline & & & & \\
\hline
\end{tabular}


Center for Archaeological Research - UTSA

L \& L Project - Laughlin Phase

UNIQUE ITEM LOG

\begin{tabular}{|c|c|c|c|c|}
\hline Unique \# & Provenience & Description & Excavator & Date \\
\hline & & & & \\
\hline & & & & \\
\hline & & & & \\
\hline & & & & \\
\hline & & & & \\
\hline & & & & \\
\hline & & & & \\
\hline & & & & \\
\hline & & & & \\
\hline & & & & \\
\hline & & & & \\
\hline & & & & \\
\hline & & & & \\
\hline & & & & \\
\hline & & & & \\
\hline & & & & \\
\hline & & & & \\
\hline & & & & \\
\hline & & & & \\
\hline & & & & \\
\hline & & & & \\
\hline & & & & \\
\hline & & & & \\
\hline & & & & \\
\hline & & & & \\
\hline & & & & \\
\hline & & & & \\
\hline
\end{tabular}




\begin{tabular}{|c|c|c|c|c|c|c|c|c|c|c|c|c|c|}
\hline \multicolumn{14}{|c|}{ LACKLAND/LAUGHLIN PROJECT CATALOG WORKSHEET } \\
\hline \multicolumn{6}{|c|}{ Site Trinomial: } & \multirow[b]{2}{*}{ Description } & \multirow[b]{2}{*}{$\begin{array}{c}\text { Mater } \\
\text { ial }\end{array}$} & \multicolumn{6}{|c|}{ Site Field \#: } \\
\hline$\underset{\#}{\text { Cat }}$ & Unit & Level & $\underset{\#}{\mathrm{Bag}}$ & Exc Date & Quan & & & Class & $\begin{array}{l}\text { Docu } \\
\text { menta } \\
\text { tion }\end{array}$ & $\begin{array}{l}\text { Stor } \\
\text { age }\end{array}$ & $\begin{array}{c}\text { Inter } \\
\text { preta } \\
\text { tion }\end{array}$ & Comments & $\begin{array}{c}\text { Ent } \\
\text { ered } \\
\text { By }\end{array}$ \\
\hline & & & & $/ 194$ & & & & & & & & & \\
\hline & & & & 1.194 & & & & & & & & & \\
\hline & & & & $/ / 94$ & & & & & & & & & \\
\hline & & & & $/ / 94$ & & & & & & & & & \\
\hline & & & & $/ \quad / 94$ & & & & & & & & & \\
\hline & & & & $/ 194$ & & & & & & & & & \\
\hline & & & & $/ / 94$ & & & & & & & & & \\
\hline & & & & $/ / 94$ & & & & & & & & & \\
\hline & & & & $/ \quad / 94$ & & & & & & & & & \\
\hline & & & & $/ / 94$ & & & & & & & & & \\
\hline & & & & $/ / 94$ & & & & & & & & & \\
\hline & & & & $/ \quad / 94$ & & & & & & & & & \\
\hline & & & & $/ \quad / 94$ & & & & & & & & & \\
\hline & & & & $/ / 94$ & & & & & & & & & \\
\hline & & & & $/ / 94$ & & & & & & & & & \\
\hline & & & & $/ 194$ & & & & & & & & & \\
\hline & & & & $/ \quad / 94$ & & & & & & & & & \\
\hline
\end{tabular}




\section{APPENDIX D \\ LAUGHLIN SURVEY ARTIFACT CATALOG \\ (selected fields only)}




\begin{tabular}{|c|c|c|c|c|c|}
\hline \multicolumn{6}{|c|}{ LAUGHLIN SURVEY ARTIFACT CATALOG } \\
\hline Catalog \# & Unit & Level & Quantity & Description & Comments \\
\hline 4IVV1654-001 & Surface & & 1 & Thin biface midsection & UI\#32; $21 \mathrm{~m} \mathrm{~W}$ of road, transect 4.5 \\
\hline $41 \mathrm{VV} 1654-002$ & & Surface & 1 & Thin biface, unstemmed triangular rounded base & UI $\# 33$ \\
\hline 4IVV1654-003 & ST \#72 & 1 & 2 & chunks & \\
\hline $41 \mathrm{VV} 1654-004$ & ST\#49 & 1 & 1 & Uniface & \\
\hline $41 \mathrm{VV} 1654-005$ & ST\#90 & 1 & 1 & Secondary Flake & At Dog Leash \#5 \\
\hline 41 VV1654-006 & & Surface & 1 & Wilson point & UIH37; N part of sile \\
\hline 41VV1654-007 & ST\#78 & 1 & 1 & Chunk & \\
\hline 4IVV1654-008 & ST\#75 & 5 & 1 & Unmodified Primary Flake & \\
\hline 41VV1654-009 & STH75 & 4 & 1 & Secondary flake & \\
\hline 41 VV1654-010 & STH74 & 5 & 1 & Unmod. Tertiary Flake & \\
\hline 41 VV1654-011 & & Surface & 1 & Reworked dart point & UI $\# 34$ \\
\hline 41 VV1654-012 & STH88 & 2 & 1 & Semi-porcelain & \\
\hline 41 VV1654-013 & & Surface & 1 & Thin oval to eliptical biface & UIH38; 20 due south of STH72 \\
\hline 41VV1654-014 & STH49 & 4 & 1 & Unmodified secondary flake & \\
\hline 4IVV1654-015 & STH81 & 1 & 1 & Secondary flake & \\
\hline 41VV1654-016 & STH49 & II & 1 & Thin biface-medial fragment & \\
\hline 41VV1654-017 & STH88 & 3 & 3 & Clear window glass & Historic component \\
\hline 41VV1654-018 & STH84 & 2 & 1 & Core Fragment & \\
\hline 41 VV1654-019 & & Surface & 1 & Thin biface-proximal fragment & UI\#35 \\
\hline $41 \mathrm{VV} 1654-020$ & ST\#72 & 3 & 1 & Unmod. secondary chip & \\
\hline 41 VV1654-021 & DLH6 & Surface & 1 & Thick biface-edge modified & \\
\hline 41 VV1654-022 & STH84 & 1 & 1 & Unmod. primary flake & \\
\hline 41VV1654-023 & DL\#1 & Surface & 1 & Clear glass bottle fragment (sun-purpled) & Historic / lithic debris scatter near feature $\mathrm{C}$ \\
\hline 4IVV1654-024 & DLA1 & Surface & 1 & Distal point fragment & \\
\hline 41 VV1654-025 & & Surface & 1 & Thin biface, straight stem & In road by backhoe trench \# 6 \\
\hline $41 \mathrm{VV} 1654-026$ & ST\#74 & 1 & 1 & Mod. Secondary Flake & \\
\hline $41 \mathrm{VV} 1654-027$ & ST \#74 & 1 & 1 & Unmod. secondary flake & \\
\hline 41VV1654-028 & ST\#73 & 2 & 1 & Unmod. Secondary Flake & \\
\hline 41 VV1654-029 & ST\#78 & 2 & 1 & Modified secondary flake & \\
\hline 41 VV1654-030 & & Surface & 1 & Thin biface--reworked & \\
\hline
\end{tabular}




\begin{tabular}{|c|c|c|c|c|c|}
\hline \multicolumn{6}{|c|}{ LAUGHLIN SURVEY ARTIFACT CATALOG } \\
\hline Catalog \# & Unit & Level & Quantity & Description & Comments \\
\hline 41VV1654-031 & STH91 & 4 & 1 & Unmod. Tertiary Flake & \\
\hline 41 VV1654-032 & STH91 & 5 & 1 & Unmod. Tertiary Flake & \\
\hline 4 IVV1654-033 & STH49 & 4 & 1 & Chip & DLH5 \\
\hline 4 IVV1654-034 & STH49 & 5 & 1 & Chunk & \\
\hline 41VV1654-035 & & Surface & 1 & Pestle & UI \#8 NW part of site; from backdirt of military foxhole \\
\hline $41 \mathrm{VV} 1654-036$ & & Surface & 2 & Square nails & HIstoric component; SE end \\
\hline 41 VV1654-037 & & Surface & 1 & Metal bracket & HIstoric component; SE end; cast iron \\
\hline 41 VV1654-038 & & Surface & 1 & Metal bracket & HIstoric component; SE end; cast iron, "9 in." written on it \\
\hline 41 VVI654-039 & & Surface & 6 & Glass sherds & HIstoric component; SE end \\
\hline 4IVV1654-040 & & Surface & 2 & Undecorated whiteware sherds & HIstoric component; SE end \\
\hline 41VV1654-041 & & Surface & 1 & porcelain sherd & HIstoric component; SE end \\
\hline 41 VV1654-042 & & Surface & 1 & semi-porcelain sherds & HIstoric component; SE end \\
\hline 41 VV1654-043 & & Surface & 4 & Stoneware sherds & HIstoric component; SE end \\
\hline 41 VV1654-044 & DL\#6 & Surface & 2 & Unmod. tertiary flakes & These flakes mend \\
\hline 41 VV1654-045 & DLH1 & Surface & 1 & & Historic component \\
\hline 4IVV1654-046 & DL\#1 & Surface & 1 & & Historic component \\
\hline 41VV1654-047 & & Surface & 1 & Clear glass (sun purlpled) & \\
\hline 4IVV1654-048 & & Surface & 1 & Clear glass (sun purpled) & \\
\hline 41VV1654-049 & & Surface & 1 & Brown bottle base & \\
\hline 41 VV1654-050 & ST \#88 & 1 & 1 & Clear glass-pinkish & \\
\hline 41 VV1654-051 & & Surface & 1 & Clear glass (sun purpled) & \\
\hline 41 VV1654-052 & & Surface & 1 & Green bottle base & \\
\hline 41 VV1654-053 & & Surface & 1 & Undecorated Whiteware Fragment & "TEL" stamped on it \\
\hline $41 \mathrm{VV} 1654-054$ & & Surface & 1 & Undecorated Whiteware & foot-ring \\
\hline $41 \mathrm{VV} 1654-055$ & & Surface & 1 & Salt glazed Stoneware & \\
\hline 41 VV1654-056 & & Surface & 1 & Stoneware w/rim & \\
\hline 41 VV1654-057 & & Surface & 1 & Salt glaze stoneware & \\
\hline 41 VV1654-058 & & Surface & 2 & Stoneware frags & \\
\hline 41VV1654-059 & & Surface & 1 & Whiteware & \\
\hline 41VV1654-060 & ST H49 & 2 & 1 & Chunk & \\
\hline
\end{tabular}




\begin{tabular}{|c|c|c|c|c|c|}
\hline \multicolumn{6}{|c|}{ LAUGHLIN SURVEY ARTIFACT CATALOG } \\
\hline Catalog \# & Unit & Level & Quantity & Description & Comments \\
\hline 41VV1654-061 & ST H49 & 2 & 1 & Unmod. Tertiary flake & \\
\hline $41 \mathrm{VV} 1654-062$ & ST H49 & 2 & 1 & Mod. Secondary flake & \\
\hline 4IVV1654-063 & ST H49 & 2 & 1 & Uniface & \\
\hline 4IVV1654-064 & & Surface & 1 & Reworked dart point & \\
\hline 41 VV1654-065 & Trench B & 3 & 1 & Golodrina/Barber & \\
\hline 4lVVI654-066 & DL\#3 & Surface & 1 & Heavily reworked Gower & \\
\hline 41VV1654-067 & DL \#6 & Surface & 1 & Unmod. Secondary Flake & \\
\hline 41VV1654-068 & ST \#72 & 1 & 3 & Chips & \\
\hline 4IVV1654-069 & ST \#49 & 1 & 1 & Uniface & \\
\hline $41 \mathrm{VV} 1654-070$ & ST H49 & 1 & 4 & Chunks & \\
\hline 41VV1654-071 & ST \#90 & 1 & 4 & Chunks & \\
\hline 41VV1654-072 & ST \#90 & 1 & 1 & Uniface & \\
\hline 41 VV1654-073 & ST \#75 & 5 & 1 & Chip & \\
\hline 41 VV1654-074 & ST \#74 & 5 & 1 & Unmod. Tertiary Flake & \\
\hline 4IVV1654-075 & ST \#49 & 4 & 1 & Chunk & \\
\hline 41VV1654.076 & ST \#73 & 4 & 1 & Chip & \\
\hline $41 \mathrm{VV} 1654-077$ & ST \#73 & 4 & 1 & Chunk & \\
\hline $41 \mathrm{VV} 1654.078$ & ST \#74 & 1 & 1 & Unmod. Tertiary Flake & \\
\hline 41VV1654-079 & ST \#74 & 1 & 1 & Chip & \\
\hline $41 \mathrm{VV} 1654-080$ & ST \#78 & 2 & 1 & Mod. Tertiary flake & \\
\hline 41VV1654-081 & ST H91 & 4 & 1 & Unmod. Secondary Chip & \\
\hline 41VV1654-082 & ST \#91 & 4 & 3 & Chips & \\
\hline $41 \mathrm{VV} 1655-001$ & STH89 & 1 & 1 & Mod. secondary flake & \\
\hline 41VV1655-002 & STH89 & 2 & 2 & Unmod. Primary flake with edge damage & \\
\hline $41 \mathrm{VV} 1655-003$ & ST \#89 & 2 & 1 & Mod. Secondary Flake & \\
\hline $41 \mathrm{VV} 1682-001$ & STH5 & & 5 & Barbed wire fragments & \\
\hline 4IVV1682-002 & STH5 & & 5 & Mortar fragments & \\
\hline 4IVV1682-003 & & Surface & 1 & "Clabber Girl" Baking Powder lid; UI \#1 & $43 \mathrm{~m}$ at 43 degrees from main datum \\
\hline $41 \mathrm{VV} 1682-004$ & STH2 & 1 & 1 & Wire Nail & \\
\hline 4lVV1682-005 & & Surface & 1 & Sm. bottle base & \\
\hline
\end{tabular}




\begin{tabular}{|c|c|c|c|c|c|}
\hline \multicolumn{6}{|c|}{ LAUGHLIN SURVEY ARTIFACT CATALOG } \\
\hline Catalog \# & Unit & Level & Quantity & Description & Comments \\
\hline $41 \mathrm{VV} 1682-006$ & Ftr. C & Surface & 1 & Sm. bottle bottom; UI \#7 & Maker's Mark \\
\hline 41VV1682-007 & Ftr. D & Surface & 1 & Brick & UIH2 Post 1920 \\
\hline 4IVV1682-008 & & Surface & 1 & Metal tool fragment & UII\#4; unidentifiable \\
\hline 4IVV1683-001 & STH10 & 1 & 1 & Chunk & \\
\hline 4IVVI683-002 & STH12 & 1 & 1 & Chunk & modified? \\
\hline 41 VV1683-003 & & Surface & 1 & Angostura-like point fragment & \\
\hline 41VV1683-004 & $S T H 7$ & 1 & 1 & Thin biface fragment & \\
\hline 41 VV1683-005 & & Surface & 1 & Thin biface fragment & SW comer \\
\hline 41VV1683.006 & STHA & 1 & 1 & Unmod. tertiary flake & \\
\hline 41 VV1683-007 & STH7 & 4 & 1 & Unmod. secondary flake & \\
\hline 41 VV1683-008 & STH7 & 5 & 1 & Mod. tertiary flake & \\
\hline 41VV1683-009 & STH10 & 2 & 1 & Chunk & \\
\hline $41 \mathrm{VV} 1683.010$ & ST\#8 & 1 & 2 & Chunks & \\
\hline $41 \mathrm{VV} 1683-011$ & STH7 & 2 & 10 & Bone fragments & Unidentifiable bone fragments \\
\hline 41 VV1683-012 & STH7 & 2 & 1 & Unmod. tertiary flake & \\
\hline 41 VV1683-013 & STH7 & 2 & 1 & Bone-UID bird & \\
\hline 41VV1683-014 & STH7 & 2 & 1 & Bone-Sylvilagus sp. & \\
\hline 41VV1683-015 & ST\#7 & 2 & 2 & Chips & \\
\hline $41 \mathrm{VV} 1684-001$ & Area A & Surface & 1 & Mod. secondary flake & \\
\hline 41VV1684.002 & STH23 & I & 1 & Mod. secondary flake & Area A \\
\hline 41VV1684-003 & STH23 & 1 & 1 & Chunk & Area A \\
\hline 41 VV1685-001 & Surface & & 1 & Uniface & UI \#11 \\
\hline 41VV1685-002 & Area D/DL \#1 & Surface & 1 & Thin biface-distal fragment & \\
\hline 41VV1685-003 & Area D/DL \#2 & Surface & 1 & UID point fragment & \\
\hline 41 VV $1685-004$ & Area D/DL \#1 & Surface & 1 & Uniface & \\
\hline 41 VV1685-005 & Area D/DL \#1 & Surface & 1 & Subdiscoidal biface tool & \\
\hline 41 VV1685-006 & Area D/DL \#1 & Surface & 1 & Thick biface & \\
\hline 41VV1685-007 & Area D/DL \#1 & Surface & 1 & Multi-directional core fragment & \\
\hline $41 \mathrm{VV} 1685-008$ & Area $\mathrm{A}$ & Surface & 1 & Thin rectangular biface fragment & UI \#14; possible gouge \\
\hline 41 VV1685-009 & Area $\mathrm{C}$ & Surface & 2 & Thin leaf-to-ovate biface in two pieces & UI\# 10; Fragments were found ca. 1 meter apart \\
\hline
\end{tabular}




\begin{tabular}{|c|c|c|c|c|c|}
\hline \multicolumn{6}{|c|}{ LAUGHLIN SURVEY ARTIFACT CATALOG } \\
\hline Catalog \# & Unit & Level & Quantity & Description & Comments \\
\hline $41 \mathrm{VV} 1685.010$ & Area A/DL \#2 & Surface & 2 & Thin narrow biface in two pieces & \\
\hline $41 \mathrm{VV} 1685-011$ & Area D/DL \#2 & Surface & 1 & Mod. secondary flake & \\
\hline $41 \mathrm{VV} 1685-012$ & 25 & 1 & 1 & Chunk & Area D \\
\hline 4 IVV1685-013 & STH57 & 3 & 1 & Mod. secondary flake & AreaC \\
\hline 4IVV1685-014 & & Surface & 1 & UID distal point fragment & UIH13; sector 15 area $\mathrm{A}$ \\
\hline 41 VV1685-015 & ST \#60 & 2 & 1 & Unmod. tertiary flake & \\
\hline $41 \mathrm{VV} 1685-016$ & ST \#60 & 2 & 1 & Core fragment & Sector 15 area $B$ \\
\hline $41 \mathrm{VV} 1685-017$ & ST \#60 & 2 & 1 & Chunk & \\
\hline 41 VV1685-018 & ST \#60 & 2 & 1 & Biface Fragment & Possible tool \\
\hline 41 VV1686-001 & DL1 & Surface & 1 & Thin biface-proximal fragment & $\mathrm{UI} \# 24$ \\
\hline 4lVV1686-002 & ST\#26 & 1 & 1 & Core Fragment & \\
\hline 41 VV1686-003 & ST\#26 & 3 & 1 & Mod tertiary flake & \\
\hline 41 VV1686-004 & & Surface & 1 & Small thin oval biface & $\mathrm{UI} \# 23 ; 8 \mathrm{~m}$ at 230 degrees from site datum \\
\hline 41 VV1686-005 & & Surface & 1 & Thin biface, prox. fragment, patinated & UI $\$ 21 ; 4 \mathrm{~m}$ at 290 degrees from site datum \\
\hline 41 VV1686-006 & ST\#27 & 1 & 1 & Mod, secondary flake & \\
\hline $41 \mathrm{VV} 1687-001$ & ST\#28 & 2 & 1 & Unmod. secondary flake & \\
\hline $41 \mathrm{VV} 1687-002$ & STH28 & 1 & 1 & Mod, secondary flake & \\
\hline 41 VV1687-003 & STH30 & 1 & 1 & Core fragment & \\
\hline 41 VV1687-004 & ST \#28 & 2 & 1 & Burned secondary chip & \\
\hline 41 VV1687-005 & ST \#28 & 1 & 1 & Unmod. tertiray flake & \\
\hline 4 IVV1687-006 & ST H28 & 1 & 1 & Tertiary chip & \\
\hline $41 \mathrm{VV} 1688-001$ & & Surface & 1 & Heavily reworked Kinney-like point & UIH23 \\
\hline 4IVV1688-002 & STH36 & 3 & 1 & Chunk & \\
\hline $41 \mathrm{VV} 1688-003$ & STH32 & 1 & 2 & Trimmmed tertiary flake & multibit \& graver \\
\hline 41 VV1688-004 & & Surface & 1 & Thin ovate biface & UI\#25; $4.7 \mathrm{~m}$ at 300 degrees from Dogleash 1 datum \\
\hline 4 IVV1688-005 & & Surface & 1 & Ensor point-missing distal end & UI\#27 \\
\hline 4IVV1688-006 & STH33 & 1 & 1 & Unmod. tertiary flake & \\
\hline 4l VV1688-007 & STH33 & 1 & 1 & Chunk & \\
\hline 41VV1688-008 & ST \#32 & 1 & 1 & Unmod. tertiary flake & \\
\hline 41 VV1688-009 & DL \#2 & Surface & 1 & Small shoulderless lanceolate dart point & \\
\hline
\end{tabular}




\begin{tabular}{|l|l|l|c|l|l|}
\hline \multicolumn{5}{|c|}{ LAUGHLIN SURVEY ARTIFACT CATALOG } \\
\hline Catalog \# & Unit & Level & Quantity & Description & Comments \\
\hline & & & & & \\
\hline 41 VV1689-001 & & Surface & 1 & Heavily reworked Bandy/Martindale point & UI\#28 \\
\hline 41 VV1689-002 & STH37 & 2 & 1 & Core fragment & \\
\hline 41 VV1690-001 & Surface & & 1 & Thin ovate biface fragment & UI\#31 \\
\hline 41 VV1690-002 & Ftr. A & Surface & 1 & Pedernales point stem only & UI \#30; Associated with recent hearth \\
\hline 41VV1691-001 & STH41 & I & 1 & Uniface fragment & graver fragment \\
\hline IF 10LGH-001 & IF-21 & Surface & 1 & Early Corner-notched point fragment & UI\#9; sector 7 \\
\hline IF 11LGH-001 & IF \#11 & Surface & 1 & Thin biface-distal fragment & UI\#29 \\
\hline IF 21LGH-001 & IF $\# 21$ & Surface & 1 & Unidentified lithic piece & Sector 15 S of creek; tool? \\
\hline IF 22LGH-001 & & Surface & 1 & Thin biface-distal fragment & $12 ;$ Sector $15 \mathrm{~S}$ of creek E of road \\
\hline
\end{tabular}




